Prepared in cooperation with the Bureau of Reclamation

\title{
Quantifying Seepage Using Heat as a Tracer in Selected Irrigation Canals, Walker River Basin, Nevada, 2012 and 2013
}

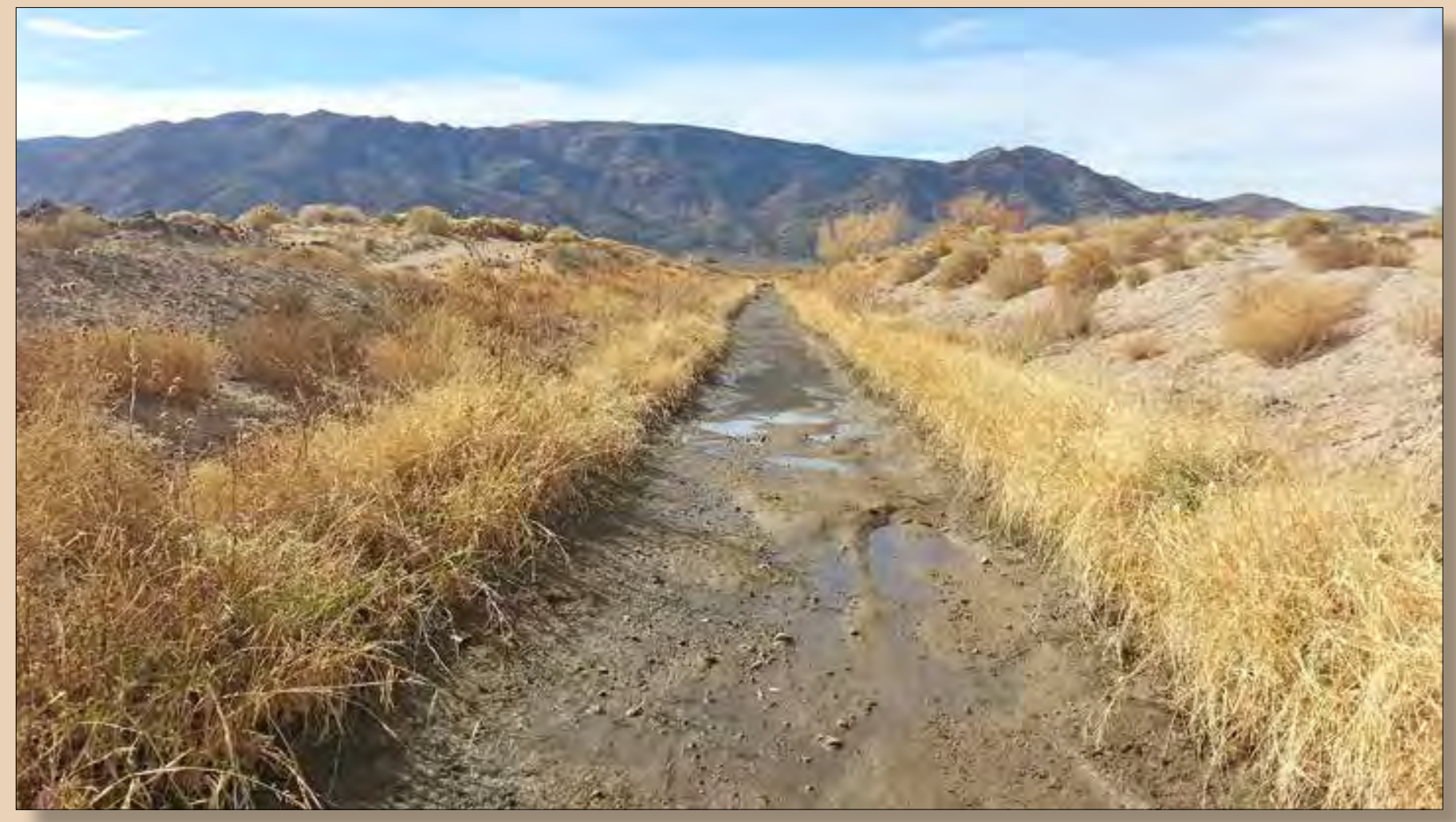

Scientific Investigations Report 2016-5133 
Photograph of SARONI CANAL 2.1, near Wellington, Smith Valley, Nevada, looking upstream on November 6, 2013. Photograph taken by David W. Smith, U.S.

Geological Survey. 


\section{Quantifying Seepage Using Heat as a Tracer in Selected Irrigation Canals, Walker River Basin, Nevada, 2012 and 2013}

By Ramon C. Naranjo and David W. Smith

Prepared in cooperation with the Bureau of Reclamation

Scientific Investigations Report 2016-5133 


\title{
U.S. Department of the Interior SALLY JEWELL, Secretary
}

\section{U.S. Geological Survey Suzette M. Kimball, Director}

\author{
U.S. Geological Survey, Reston, Virginia: 2016
}

For more information on the USGS - the Federal source for science about the Earth, its natural and living resources, natural hazards, and the environment-visit http://www.usgs.gov or call 1-888-ASK-USGS.

For an overview of USGS information products, including maps, imagery, and publications, visit http://store.usgs.gov/.

Any use of trade, firm, or product names is for descriptive purposes only and does not imply endorsement by the U.S. Government.

Although this information product, for the most part, is in the public domain, it also may contain copyrighted materials as noted in the text. Permission to reproduce copyrighted items must be secured from the copyright owner.

Suggested citation:

Naranjo, R.C., and Smith, D.W., 2016, Quantifying seepage using heat as a tracer in selected irrigation canals, Walker River Basin, Nevada, 2012 and 2013: U.S. Geological Survey Scientific Investigations Report 2016-5133, 169 p., http://dx.doi.org/10.3133/sir20165133.

ISSN 2328-0328 (online) 


\section{Acknowledgments}

The authors thank the Walker River Irrigation District and the Walker River Paiute Indian Reservation for permission to access study sites for equipment installation and monitoring. Special thanks to Keith Halford for parameter estimation support and providing new tools for generating PEST input files, and Richard Niswonger for VS2DH modeling support. Thanks also go out to student hydrologist Steven Clarke for field support, geographic information system (GIS) analysis and Matlab code development that substantially reduced temperature data processing time. Thanks to Michael Barrenchea, Stephen Maples, and Murphy Gardner for assistance with equipment installation and data collection. The authors are also grateful to the technical reviewers of this report, including David Stonestrom of the U.S. Geological Survey and Rosemary Carroll of the Desert Research Institute. 


\section{Contents}

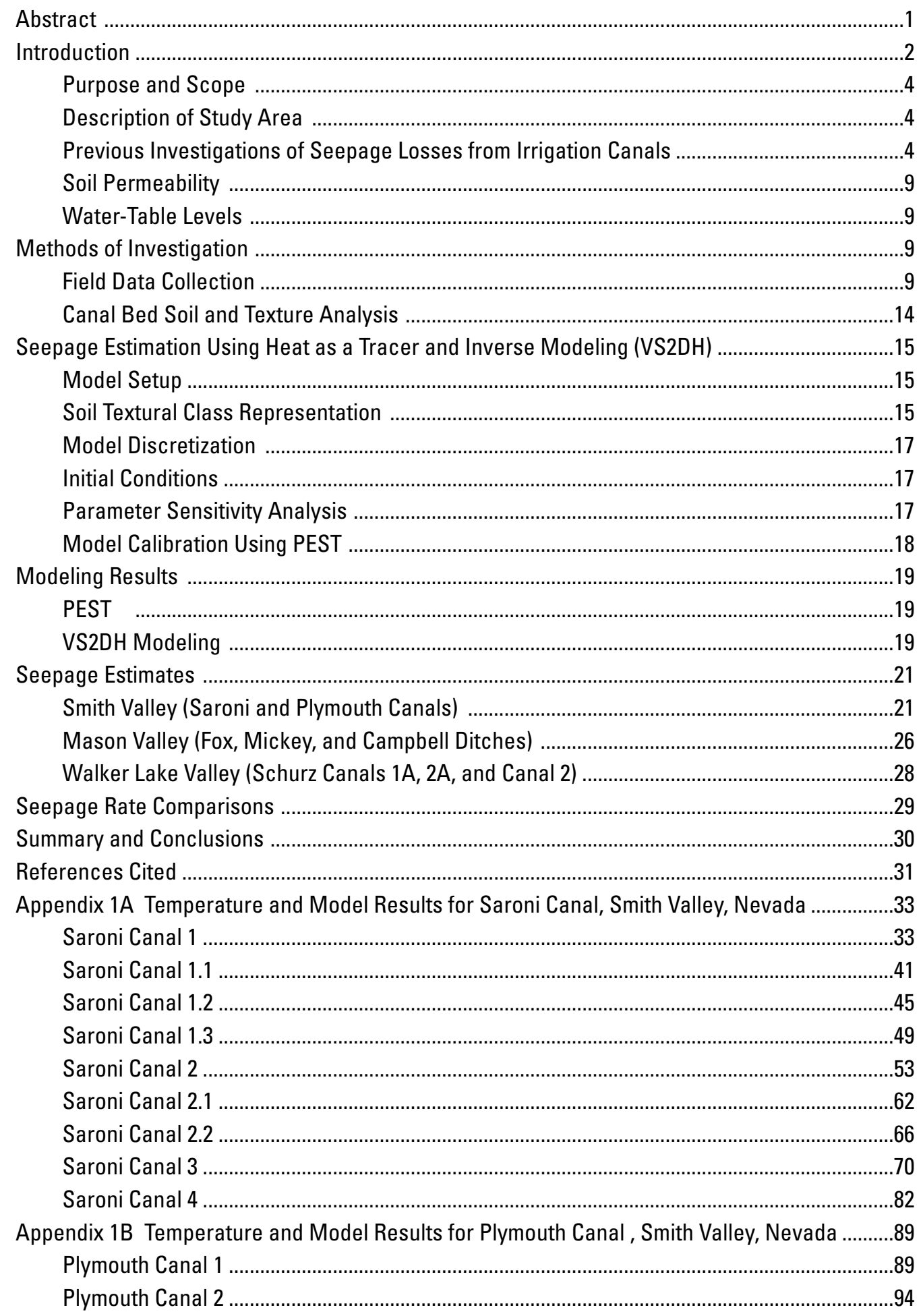


Appendix 2A Temperature and Model Results for Fox Ditch, Mason Valley, Nevada ...................99

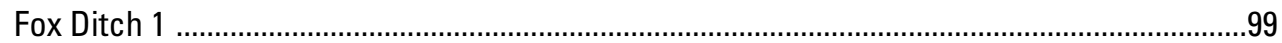

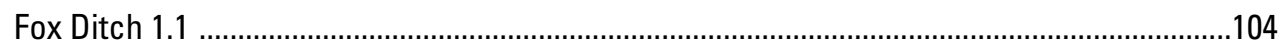

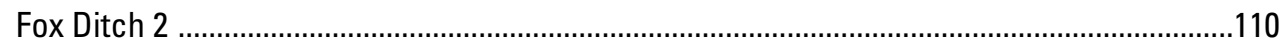

Appendix 2B Temperature and Model Results for Mickey Ditch, Mason Valley, Nevada ..........116

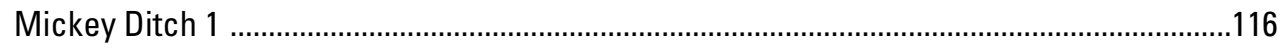

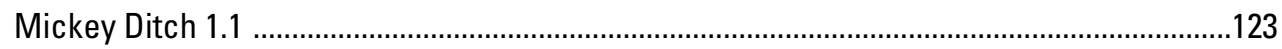

Appendix 2C Temperature and Model Results for Campbell Ditch, Mason Valley, Nevada .......127

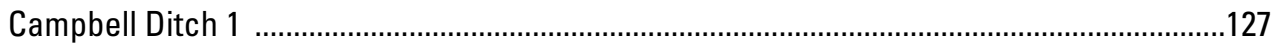

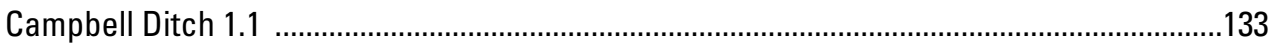

Campbell Ditch 2 ...........................................................................................................137

Appendix 3A Temperature and Model Results for Schurz Lateral 1A Canal, Walker Lake Valley, Nevada ...... 142

Schurz 1 Lateral 1A Canal .............................................................................................................. 142

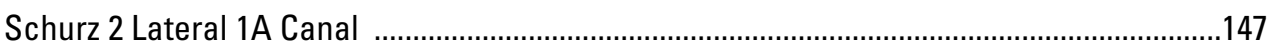

Appendix 3B Temperature and Model Results for Schurz 3 Lateral 2A Canal, Walker

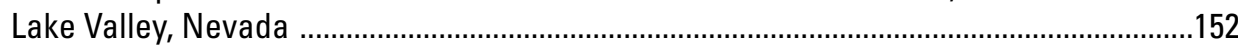

Appendix 3C Temperature and Model Results for Schurz 4 Canal 2, Walker Lake

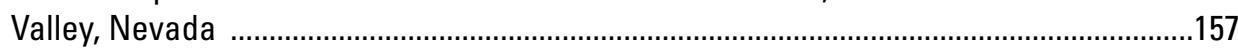

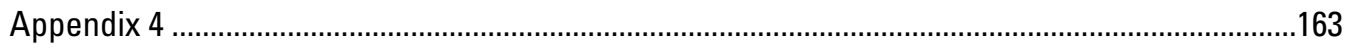

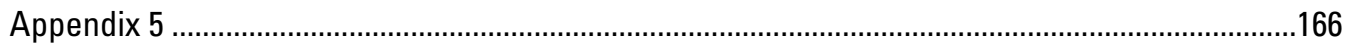

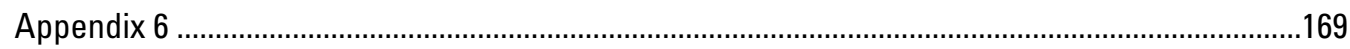

\section{Figures}

1. Map showing location of Walker River Basin study area, Nevada ........................................

2. Maps showing soil permeability along irrigation canals in Smith, Mason, and

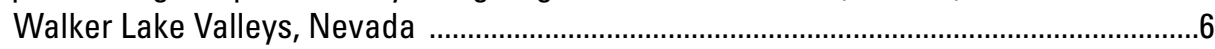

3. Maps showing depth to groundwater along irrigation canals in Smith, Mason, and Walker Lake Valleys, Nevada ...........................................................................10

4. Generalized diagram showing instrumentation monitoring design for seepage estimation in the Walker River Basin, Nevada

5. Piper diagrams showing soil core classifications for canal samples taken at transect sites in Smith, Mason, and Walker Lake Valleys, Nevada

6. Schematics showing array of temperature and pressure sensors in piezometers and wells in and adjacent to canals, and relative percent saturation of canal sediments in a hydraulically connected, transition, and disconnected canal ................16

7. Generalized two-dimensional VS2DH model showing water and heat transport through canal-bed sediments

8. Graphs showing sensitivity of hydraulic and thermal parameters to temperature error as indicated by percent bias and canal seepage

9. Maps showing estimated rates of seepage from selected irrigation canals in Smith, Mason, and Walker Lake Valleys, Nevada 
10. Photographs of SARONI CANAL 1 site TROD T10 during site installation, showing closeup of TROD T10 head, during canal flow, and approximate location of buried TROD T10

11. Graphs showing measured stage and piezometric head in 2012-13 at site 1 on the Mickey ditch and Campbell ditch

12. Graphs showing canal seepage loss rates in relation to stage in the Schurz study area for a lateral canal with intermittent periods of no flow and, a main canal with consistent flow

\section{Tables}

1. Monitoring locations and measurement periods for canal seepage transect sites in the Walker River Basin, Nevada

2. Summary of hydraulic and thermal parameters used as input into PEST to calibrate the VS2DH transect models

3. Summary statistics of the calculated root mean square error (RMSE) and percent bias (PBIAS) for the calibration and prediction periods

4. Median hydraulic and thermal conductivity of canal sediments estimated by PEST ..........21

5. Seepage estimates for canal transect sites simulated in 2012 in Smith and Mason

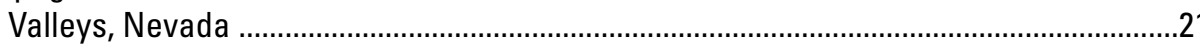

6. Seepage estimates for canal transect sites simulated in 2013 in Smith, Mason, and Walker Lake Valleys, Nevada

7. Annual average seepage loss for selected irrigation canals in Smith, Mason, and Walker Lake Valleys, Nevada 


\section{Conversion Factors and Datums}

Inch/Pound to International System of Units

\begin{tabular}{lcl}
\hline \multicolumn{1}{c}{ Multiply } & By & \multicolumn{1}{c}{ To obtain } \\
\hline foot $(\mathrm{ft})$ & Length & \\
mile $(\mathrm{mi})$ & 0.3048 & meter $(\mathrm{m})$ \\
\hline \multicolumn{3}{c}{ kilometer $(\mathrm{km})$} \\
\hline acre & 1.609 & \\
square mile $\left(\mathrm{mi}^{2}\right)$ & 4,047 & square meter $\left(\mathrm{m}^{2}\right)$ \\
\hline & 2.590 & square kilometer $\left(\mathrm{km}^{2}\right)$ \\
\hline mile per hour $(\mathrm{mi} / \mathrm{h})$ & Velocity & \\
\hline & 1.609 & kilometer per hour $(\mathrm{km} / \mathrm{h})$ \\
\hline acre-foot $($ acre-ft) & Volume & \\
\hline & 1,233 & cubic meter $\left(\mathrm{m}^{3}\right)$ \\
\hline foot per day $(\mathrm{ft} / \mathrm{d})$ & Flow rate & meter per day $(\mathrm{m} / \mathrm{d})$ \\
cubic foot per second $\left(\mathrm{ft}^{3} / \mathrm{s}\right)$ & 0.3048 & cubic meter per second $\left(\mathrm{m}^{3} / \mathrm{s}\right)$ \\
\hline
\end{tabular}

International System of Units to Inch/Pound

\begin{tabular}{lcl}
\hline \multicolumn{1}{c}{ Multiply } & By & \multicolumn{1}{c}{ To obtain } \\
\hline & Hydraulic conductivity & \\
\hline meter per day $(\mathrm{m} / \mathrm{d})$ & 3.281 & foot per day $(\mathrm{ft} / \mathrm{d})$ \\
meter per hour $(\mathrm{m} / \mathrm{h})$ & 3.281 & foot per hour $(\mathrm{ft} / \mathrm{h})$ \\
\hline \multicolumn{3}{c}{ Length } \\
\hline centimeter $(\mathrm{cm})$ & 0.394 & inch $(\mathrm{in})$. \\
meter $(\mathrm{m})$ & 3.281 & foot $(\mathrm{ft})$ \\
\hline
\end{tabular}

Temperature in degrees Celsius $\left({ }^{\circ} \mathrm{C}\right)$ can be converted to degrees Fahrenheit $\left({ }^{\circ} \mathrm{F}\right)$ as follows:

$$
{ }^{\circ} \mathrm{F}=\left(1.8 \times{ }^{\circ} \mathrm{C}\right)+32
$$

Temperature in degrees Fahrenheit $\left({ }^{\circ} \mathrm{F}\right)$ can be converted to degrees Celsius $\left({ }^{\circ} \mathrm{C}\right)$ as follows:

$$
{ }^{\circ} \mathrm{C}=\left({ }^{\circ} \mathrm{F}-32\right) / 1.8
$$

Vertical coordinate information is referenced to the North American Vertical Datum of 1988 (NAVD 88).

Horizontal coordinate information is referenced to the North American Datum of 1983 (NAD 83). Altitude, as used in this report, refers to distance above the vertical datum. 


\author{
Abbreviations and Acronyms \\ HA hydrographic area \\ PBIAS percent bias \\ PEST Parameter ESTimation \\ RMSE root mean square error \\ RTK GNSS Real-time kinematic Global Navigation Satellite Systems \\ USGS U.S. Geological Survey \\ VG Alpha van Genuchten Alpha \\ VG Beta van Genuchten Beta \\ WRID Walker River Irrigation District \\ WRPIR Walker River Paiute Indian Reservation
}




\title{
Quantifying Seepage Using Heat as a Tracer in Selected Irrigation Canals, Walker River Basin, Nevada, 2012 and 2013
}

\author{
By Ramon C. Naranjo and David W. Smith
}

\section{Abstract}

The Walker River is an important source of water for western Nevada. The river provides water for agriculture and recharge to local aquifers used by several communities. Farmers began diverting water from the Walker River in the 1860 s to support growing agricultural development. Over time, the reduced inflows into Walker Lake from upstream reservoirs and diversions have resulted in 170 feet of lake level decline and increased dissolved-solids concentrations to levels that threaten aquatic ecosystems, including survival of Lahonton cutthroat trout, a native species listed in the Endangered Species Act. Investigations of the water-budget components in the Walker River Basin have revealed uncertainty in the recharge to aquifers from irrigation canals. To address this need, the U.S. Geological Survey conducted an extensive field study from March 2012 through October 2013 to quantify seepage losses in selected canals in the Smith Valley, Mason Valley, and Walker Lake Valley irrigation areas.

The seepage rates estimated for the 2012 and 2013 irrigation seasons in the Smith Valley transect sites (Saroni and Plymouth canals) ranged between 0.01 to 2.5 feet per day (ft/d) (0.01 to 0.68 cubic feet per second per mile $\left.\left[\mathrm{ft}^{3} / \mathrm{s}-\mathrm{mi}\right]\right)$. From 2012 to 2013, the average number of days the canals had flowing water decreased from 190 to 125 due to drier climate and lack of water available for diversion from the Walker River. The nearly 50-percent reductions in volumetric loss rates between 2012 and 2013 were associated with less than average diversions into canals from the Walker River and reductions in infiltration rates following routine canal maintenance.

Models developed for the Saroni canal in 2012 were recalibrated in 2013 to evaluate changes in seepage as a result of siltation. Just prior to the 2012 irrigation season, nearly the entire length of the canal was cleared of vegetation and debris to improve flow conveyance. In 2013, following the first year of maintenance, a 90-percent reduction in seepage was observed at one of the transect sites. The removal of sedimentclogged layers during canal maintenance may have more profound effects on seepage rates beyond what was observed at the transect sites. The seepage rates for the Saroni canal in
2012 ranged from 0.02 to $1.6 \mathrm{ft} / \mathrm{d}\left(0.03\right.$ to $\left.0.4 \mathrm{ft}^{3} / \mathrm{s}-\mathrm{mi}\right)$. The total seepage loss in the Saroni canal for the 2012 and 2013 irrigation seasons was estimated to be 1,100 and 590 acre-feet (acre-ft), respectively.

Seepage rates on the Plymouth canal in Smith Valley in 2012 were among the lowest, ranging from 0.01 to $0.2 \mathrm{ft} / \mathrm{d}$ (0.01 to $\left.0.1 \mathrm{ft}^{3} / \mathrm{s}-\mathrm{mi}\right)$. In 2013, the seepage rate on the Plymouth canal was similar to 2012; however, the volumetric loss was reduced by 50 percent due to the 50 -percent reduction in number of canal flow days. Lower rates of seepage on the Plymouth canal for the 2012 and 2013 irrigation seasons were estimated to be 210 and 130 acre-ft, respectively.

The seepage rates estimated for the 2012 and 2013 irrigation seasons in the Mason Valley transect sites (Fox, Mickey, and Campbell ditches) ranged from 0.1 to $3.3 \mathrm{ft} / \mathrm{d}(0.2$ to $\left.1.3 \mathrm{ft}^{3} / \mathrm{s}-\mathrm{mi}\right)$. The influence of water-table declines on seepage was observed at the Mickey and Campbell ditches. In 2012, the estimated seepage on the Mickey ditch was $1.6 \mathrm{ft} / \mathrm{d}$ during a period when the water-table altitude was at or above the canal altitude. Following extensive declines in the water table, the hydraulic gradient increased between the canal and the shallow aquifer, thereby increasing the seepage rates to $3.2 \mathrm{ft} / \mathrm{d}$ in 2013. During the period of hydraulic disconnection, seepage rates increased to $9.5 \mathrm{ft} / \mathrm{d}$ during intermittent periods of canal flow. For the Mickey ditch, the seepage loss in 2013 was 1.5 times the rate estimated in 2012 despite the canal having 45 days less flow. Similarly, the Campbell ditch seepage loss increased slightly from 660 to 700 acre-ft, a factor of 1.1, with 49 days less flow. The seepage loss for the Fox ditch did not exhibit significant year to year variability. The annual seepage loss estimated for 2012 and 2013 in the Fox ditch was 2,100 and 2,200 acre-ft, respectively.

The seepage rates estimated for the 2013 irrigation season in the Walker Lake Valley transect sites (Schurz Lateral Canals $1 \mathrm{~A}$ and 2A, and Canal 2) ranged from 0.7 to $0.9 \mathrm{ft} / \mathrm{d}$ (0.4 to $\left.1.3 \mathrm{ft}^{3} / \mathrm{s}-\mathrm{mi}\right)$. In Walker Lake Valley, diversions into Lateral Canals $1 \mathrm{~A}$ and 2A during the 2013 irrigation season were highly intermittent, a characteristic common of lateral diversions. The annual estimated seepage loss in Walker Lake Valley ranged between 50 and 725 acre-ft among the transect sites. 


\section{Introduction}

The 3,950-square mile $\left(\mathrm{mi}^{2}\right)$ Walker River Basin is a topographically closed basin in west-central Nevada where surface water drains toward Walker Lake, the lowest point in the basin and the terminus of the Walker River (fig. 1). The Walker River Basin is defined by seven hydrographic areas (HAs), consisting of Antelope Valley (HA 106), Smith Valley (HA 107), Mason Valley (HA 108), East Walker Area (HA 109), and Walker Lake Valley (HA 110) with three sub-areas. Most of the HAs are in Nevada; however, the 25 percent of the basin in California contributes to most of the surface flow from snowmelt in the Sierra Nevada Mountains. The Walker River is the main source of inflow, but small tributaries from adjacent mountains and groundwater also discharge into Walker Lake (Everett and Rush, 1967; Schaefer, 1980). The only outflow from Walker Lake is evaporation from the lake surface (Lopes and Allander, 2009b). Farmers began diverting water from the Walker River in the 1860s to support agricultural development based primarily on alfalfa. The areas of intensive agriculture are principally in Bridgeport Valley, Antelope Valley, Smith Valley, and Mason Valley.

Federal support has facilitated the investigation of water resources and the purchase of water rights to restore Walker Lake levels and improve water quality. Defined in Section 2507 of Public Law 107-171 (the 2002 Farm Bill) the allocation of \$200 million used by the Secretary of the Interior, acting through the Commissioner of Reclamation, was intended to provide water to at-risk natural desert terminal lakes. The bill was later amended under Public Law 108-7, section 207 to include this language: "Restoration of fish, wildlife, and associated habitats in watersheds of certain lakes." The amendment specified that only Pyramid, Summit, and Walker Lakes in Nevada were to be considered under Section 2507, Public Law 107-171. In 2009, the National Fish and Wildlife Foundation began efforts to purchase water rights and water leasing, provide water management initiatives and community-based conservation and stewardship, and to support applied research to reduce upstream usage and increase flows into Walker Lake as part of the Walker Basin Restoration Program established by Congress under Public Law 111-85 (http://www.walkerprogram.org/).
The U.S. Geological Survey (USGS), in cooperation with the Bureau of Reclamation (Reclamation), began a series of investigations of water resources in the lower Walker River Basin below Wabuska (fig. 1) from 2004-09. This work has resulted in updated Walker Lake bathymetry (Lopes and Smith, 2007), revised estimates of precipitation in west-central Nevada including the Walker Lake Basin (Lopes and Medina, 2007), a study on evapotranspiration of native vegetation and agricultural areas in the lower Walker River Basin including Walker Lake (Allander and others, 2009), basin hydrology (Lopes and Allander, 2009a), water budgets (Lopes and Allander, 2009b), and the use of an integrated model to simulate changes in water management on water quantity and quality to Walker Lake (Allander and others, 2014).

Researchers with the University of Nevada, Reno, and the Desert Research Institute have developed a Decision Support Tool for the purpose of evaluating management scenarios consisting of water right transfers, improved water-use efficiencies and potential water-quality improvements in the Mason Valley agricultural area (Boyle and others, unpub. data, 2013). A USGS effort is underway in the upper Walker River Basin to evaluate seasonal and decadal changes in groundwater levels and storage, changes in irrigated land and native vegetation, and seasonal changes in Walker Lake water quality. The topic of the current report, quantifying recharge from irrigation canals, is critical for the estimation of water budgets in developed valleys and for the evaluation of management scenarios that involve irrigation efficiency from the transfer of water rights within agricultural areas of the Walker River Basin.

The USGS conducted an extensive field study from March 2012 through October 2013 to quantify canal seepage losses in the Smith Valley, Mason Valley, and Walker Lake Valley irrigation areas, in cooperation with Reclamation, the Walker River Irrigation District (WRID), and the Walker River Paiute Indian Reservation (WRPIR). Instrumentation was installed in eight irrigation canals and ditches: Saroni, Plymouth, Fox, Mickey, Campbell, and Schurz Lateral Canals 1A and 2A, and Canal 2. A total of 23 transects were monitored across a wide range of soil types, flow conditions, and depth to groundwater. 


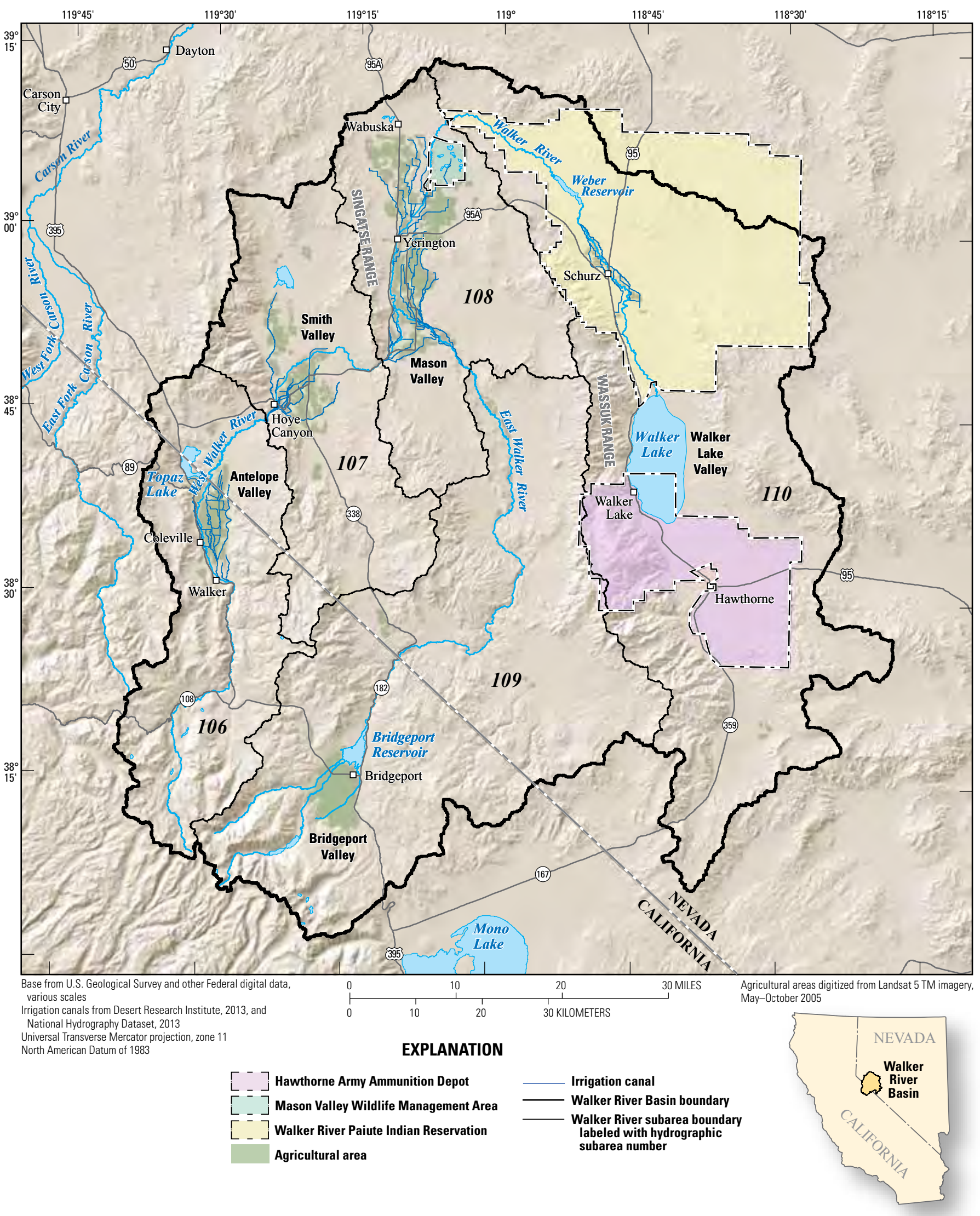

Figure 1. Location of Walker River Basin study area, Nevada. 


\section{Purpose and Scope}

The objective of this study was to estimate the seepage rates within selected irrigation canals in the Walker River Basin. Seepage was estimated for irrigation canals in the Smith Valley, Mason Valley, and Walker Lake Valley HAs. Instruments were installed at 11 transect sites in 2012, and in 2013, an additional 12 transects were monitored. This report presents information used to estimate the canal seepage rates along with descriptions of the instrumental and numerical methods used. The seepage rates were converted and scaled to units of cubic feet per second per mile $\left(\mathrm{ft}^{3} / \mathrm{s}-\mathrm{mi}\right)$ and annualized to acre-feet (acre-ft) based on the number of days water was flowing in the canal, defined as irrigation days. The report includes plots of the observed and simulated temperatures during calibration, residual errors during the prediction period, and canal stage and seepage rates for each of the study transects in appendixes 1-3. Lithologic descriptions of sediment cores, including core depth and textural classification are provided in appendix 4. Model parameters used in the seepage estimation are provided in appendix 5. Observed temperature and stage data are provided in appendix 6 .

\section{Description of Study Area}

The hydrology and associated climate of the Walker River Basin have been described in detail in USGS reports (Lopes, 2005; Lopes and Allander, 2009a, b). About 23 percent (920 square miles $\left(\mathrm{mi}^{2}\right)$ ) of the Walker River Basin is in California with most streamflow originating as snowmelt in the Sierra Nevada, the crest of which reaches an altitude of 12,300 feet (ft). Snowmelt from the Sierra Nevada and other ranges flows down the East and West Walker Rivers, which merge in southern Mason Valley, Nevada (fig. 1). Outflow from Mason Valley (inflow to the lower Walker River Basin) is recorded at the USGS Wabuska streamflow-gaging station (USGS 10301500 WALKER RV NR WABUSKA, NV) in northern Mason Valley. Stored water at Bridgeport and Topaz Lake is used to irrigate crops in Smith and Mason Valleys and to sustain a minimum streamflow of 26.25 cubic feet per second $\left(\mathrm{ft}^{3} / \mathrm{s}\right)$ at the Wabuska gage to support the senior-most water right allocated to the WRPIR.

Mean minimum and maximum temperatures in the Walker River Basin range from -4 to $35^{\circ} \mathrm{C}$, respectively, in Hawthorne, Nevada, and from -14 to $25^{\circ} \mathrm{C}$, respectively, in Bodie, Calif. The minimum recorded air temperature is about $-30^{\circ} \mathrm{C}$ and the maximum is $43{ }^{\circ} \mathrm{C}$. July is the hottest month and December typically is the coldest month. Average wind speed is from about 3 to 5 miles per hour $(\mathrm{mi} / \mathrm{h})$ on the valley floor of the lower Walker River Basin and $9 \mathrm{mi} / \mathrm{h}$ on Walker Lake.

A total of 88,600 acres of irrigated land was mapped in the Walker River Basin (Lopes and Allander, 2009b). Total irrigated land included 39,100 acres (44 percent) in Mason Valley, 18,900 acres (21 percent) in Smith Valley, 15,900 acres (18 percent) upstream from Bridgeport Reservoir, 7,700 acres
(9 percent) in Antelope Valley, 3,500 acres (4 percent) along the East Fork of the Walker River below Bridgeport Reservoir, 3,000 acres ( 3 percent) on the Paiute Tribe Reservation, and 500 acres (less than 1 percent) in Whisky Flat south of Hawthorne, Nevada. The primary crop in the basin is alfalfa, except upstream from Bridgeport Reservoir where fields are irrigated for pasture grass. Many of the agricultural areas rely on surface-water irrigation, but in low water years the demand for groundwater increases.

The canal seepage study began at the start of the 2012 irrigation season and ended in 2013; the study involved selected canals in Smith Valley, Mason Valley, and Walker Lake Valley (table 1). Canal locations were selected based primarily on access and permission given by the WRID and the WRPIR. The transect locations for each of the irrigation canals instrumented are shown in figure 2. The two canals investigated in Smith Valley were the Saroni and Plymouth. The three ditches studied in Mason Valley were the Fox, Mickey, and Campbell. The three canals in the Walker Lake Valley area were the Lateral 1A, Lateral 2A, and Canal 2; these canals are located in the small rural community of Schurz, Nevada, on the WRPIR.

\section{Previous Investigations of Seepage Losses from Irrigation Canals}

Past studies of seepage losses in the Walker River Basin are limited. Seepage investigations were typically included in early water-resources reports (1953-76) by the State of Nevada Engineers Office and the USGS. The method used for seepage estimation during this time relied on instantaneous flow measured at multiple locations along the canal. The seepage loss was determined by flow differencing (instantaneous inflow-outflow) during a relatively steady period of canal flow. In Smith Valley, seepage losses on the Saroni canal were reported to be $1.25 \mathrm{ft}^{3} / \mathrm{s}-\mathrm{mi}$, as estimated by inflow-outflow measurements made in 1949 when $47 \mathrm{ft}^{3} / \mathrm{s}$ were flowing in the canal (Leoltz and Eakin, 1953). On the basis of discussions with water managers in 1948, volumetric losses were reported to be about 800 acre-ft for about 100 days of irrigation (Leoltz and Eakin, 1953). In 1976, a waterresource investigation estimated canal seepage on Saroni and Plymouth canals to be about 4 and 5 percent of flow, respectively (Rush and Schroer, 1976), with instantaneous flow measurements in Saroni and Plymouth canals of 55 and $20 \mathrm{ft}^{3} / \mathrm{s}$, respectively. These reported estimates were qualified by the inability to differentiate return flow contributions. Seepage measurements for the irrigation canals in Mason and Walker Lake Valleys are lacking. Seepage estimates in Mason Valley for a groundwater-flow model assumed losses were 20 percent of volumetric diversion equally over the length of the canal (Carroll and others, 2010). 
Table 1. Monitoring locations and measurement periods for canal seepage transect sites in the Walker River Basin, Nevada. [Abbreviation: ID, identifier; dd, decimal degrees; NAD83, North American Datum of 1983; NAVD88, North American Vertical Datum of 1988; —, no map identifier]

\begin{tabular}{|c|c|c|c|c|c|c|c|c|}
\hline $\begin{array}{l}\text { Mar } \\
\text { ID }\end{array}$ & Site ID & Site name & Site type & $\begin{array}{c}\text { Latitude } \\
\text { (dd, NAD83) }\end{array}$ & $\begin{array}{c}\text { Longitude } \\
\text { (dd, NAD83) }\end{array}$ & $\begin{array}{l}\text { Altitude } \\
\text { (meters, } \\
\text { NAVD88) }\end{array}$ & \multicolumn{2}{|c|}{$\begin{array}{c}\text { Measuremen } \\
\text { period }\end{array}$} \\
\hline \multicolumn{9}{|c|}{ Smith Valley } \\
\hline 2 & 384456119222101 & SARONI CANAL $1.1 \mathrm{SW} / \mathrm{GW}-\mathrm{CANAL} \mathrm{SW}$ & Canal & 38.74889 & -119.37250 & $1,502.70$ & & $\mathrm{x}$ \\
\hline 3 & 384432119212801 & SARONI CANAL $1.2 \mathrm{SW} / \mathrm{GW}-\mathrm{CANAL} \mathrm{SW}$ & Canal & 38.74222 & -119.35778 & $1,501.97$ & & $\mathrm{x}$ \\
\hline 5 & 384426119195401 & SARONI CANAL 2 SW/GW-CANAL SW & Canal & 38.74056 & -119.33167 & $1,500.98$ & $\mathrm{x}$ & $\mathrm{x}$ \\
\hline 6 & 384428119191301 & SARONI CANAL 2.1 SW/GW-CANAL SW & Canal & 38.74111 & -119.32028 & $1,500.01$ & & $\mathrm{x}$ \\
\hline 7 & 384448119182701 & SARONI CANAL $2.2 \mathrm{SW} / \mathrm{GW}$-CANAL SW & Canal & 38.74667 & -119.30750 & $1,500.57$ & & $\mathrm{x}$ \\
\hline 8 & 384514119180801 & SARONI CANAL 3 SW/GW-CANAL SW & Canal & 38.75389 & -119.30222 & $1,499.67$ & $\mathrm{x}$ & $\mathrm{x}$ \\
\hline 9 & 384542119175401 & SARONI CANAL 4 SW/GW-CANAL SW & Canal & 38.76167 & -119.29833 & $1,499.06$ & $\mathrm{x}$ & $\mathrm{x}$ \\
\hline 12 & 385252119085001 & FOX DITCH 1 SW/GW-CANAL SW & Canal & 38.88111 & -119.14722 & $1,361.76$ & $\mathrm{x}$ & $\mathrm{x}$ \\
\hline- & 385252119085002 & FOX DITCH 1 SW/GW-BANK PIEZO 1 & Hyporheic-zone well & 38.88111 & -119.14722 & $1,362.87$ & $\mathrm{x}$ & $\mathrm{x}$ \\
\hline- & 385252119085003 & FOX DITCH 1 SW/GW-BANK PIEZO 2 & Hyporheic-zone well & 38.88111 & -119.14722 & $1,362.84$ & $\mathrm{x}$ & $\mathrm{x}$ \\
\hline 13 & 385253119085101 & FOX DITCH 1.1 SW/GW-CANAL SW & Canal & 38.88139 & -119.14750 & $1,363.26$ & & $\mathrm{x}$ \\
\hline 14 & 385407119093001 & FOX DITCH 2 SW/GW-CANAL SW & Canal & 38.90194 & -119.15833 & $1,354.45$ & $\mathrm{x}$ & $\mathrm{x}$ \\
\hline 15 & 385256119085001 & MICKEY DITCH 1 SW/GW-CANAL SW & Canal & 38.88222 & -119.14722 & $1,359.45$ & $\mathrm{x}$ & $\mathrm{x}$ \\
\hline- & 385256119085002 & MICKEY DITCH 1 SW/GW-BANK PIEZO 1 & Hyporheic-zone well & 38.88222 & -119.14722 & $1,360.43$ & $\mathrm{x}$ & $\mathrm{x}$ \\
\hline- & 385256119085003 & MICKEY DITCH 1 SW/GW-BANK PIEZO 2 & Hyporheic-zone well & 38.88222 & -119.14722 & $1,360.97$ & $\mathrm{x}$ & $\mathrm{x}$ \\
\hline 16 & 385344119091501 & MICKEY DITCH 1.1 SW/GW-CANAL SW & Canal & 38.89556 & -119.15417 & $1,356.45$ & & $\mathrm{x}$ \\
\hline- & 390059119102002 & CAMPBELL DITCH 2 SW/GW-BANK PIEZO 1 & Hyporheic-zone well & 39.01639 & -119.17222 & $1,332.36$ & $\mathrm{x}$ & \\
\hline- & 390059119102003 & CAMPBELL DITCH 2 SW/GW-BANK PIEZO 2 & Hyporheic-zone well & 39.01639 & -119.17222 & $1,332.80$ & $\mathrm{x}$ & \\
\hline- & 390059119102004 & CAMPBELL DITCH 2 SW/GW-BANK PIEZO 3 & Hyporheic-zone well & 39.01639 & -119.17222 & $1,332.84$ & $\mathrm{x}$ & \\
\hline \multicolumn{9}{|c|}{ Walker Lake Valley } \\
\hline 20 & 385742118503301 & SCHURZ 1 LATERAL 1A SW/GW-CANAL SW & Canal & 38.96167 & -118.84250 & $1,262.84$ & & $\mathrm{x}$ \\
\hline 21 & 385722118491601 & SCHURZ 2 LATERAL 1A SW/GW-CANAL SW & Canal & 38.95611 & -118.82111 & $1,260.79$ & & $\mathrm{x}$ \\
\hline 22 & 385713118480501 & SCHURZ 3 LATERAL 2A SW/GW-CANAL SW & Canal & 38.95361 & -118.80139 & $1,259.28$ & & $\mathrm{x}$ \\
\hline 23 & 385535118460101 & SCHURZ 4 CANAL 2 SW/GW-CANAL SW & Canal & 38.92639 & -118.76694 & $1,253.77$ & & $\mathrm{x}$ \\
\hline
\end{tabular}




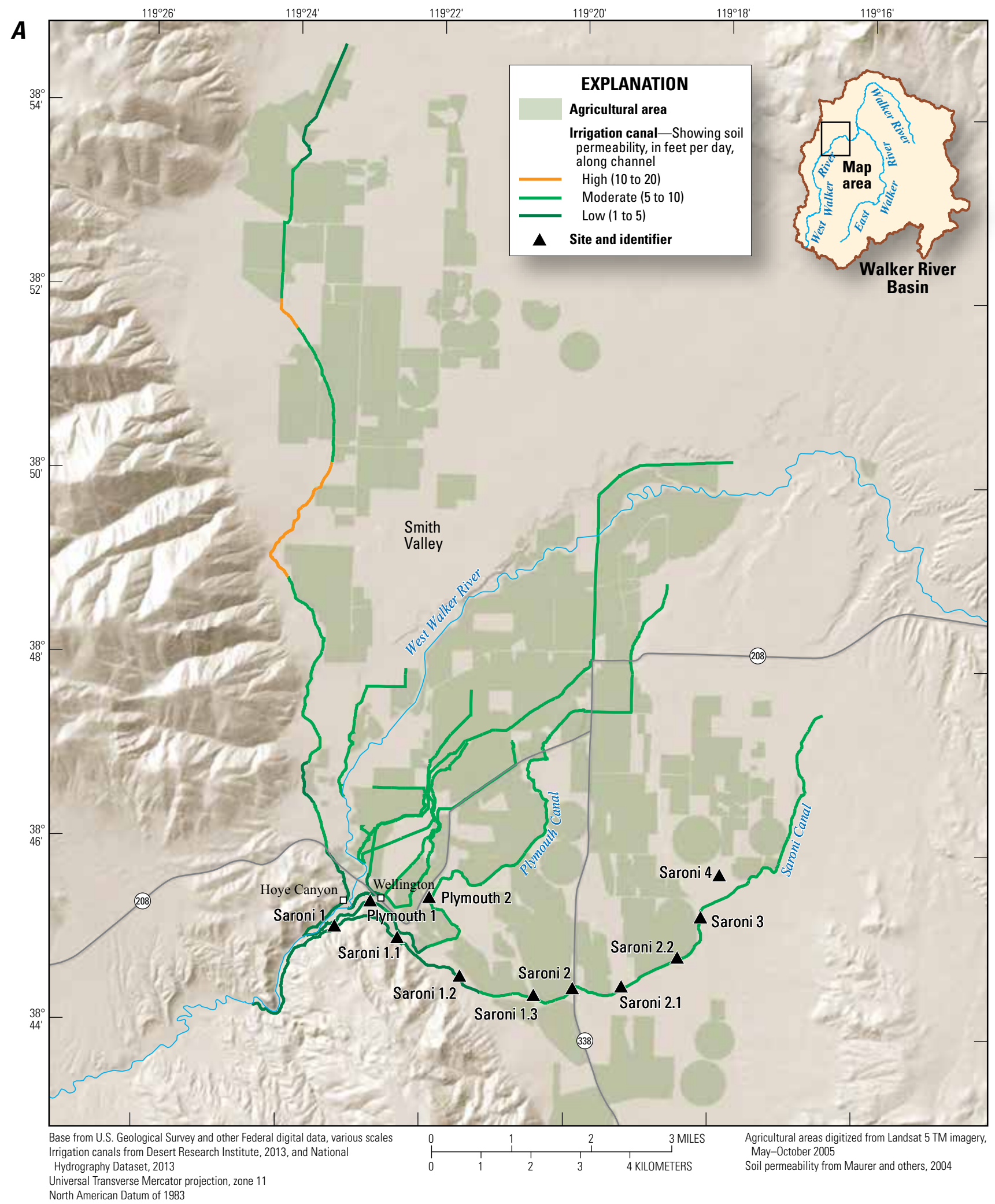

Figure 2. Soil permeability along irrigation canals in $A$, Smith Valley, $B$, Mason Valley, and $C$, Walker Lake Valley, Nevada. 


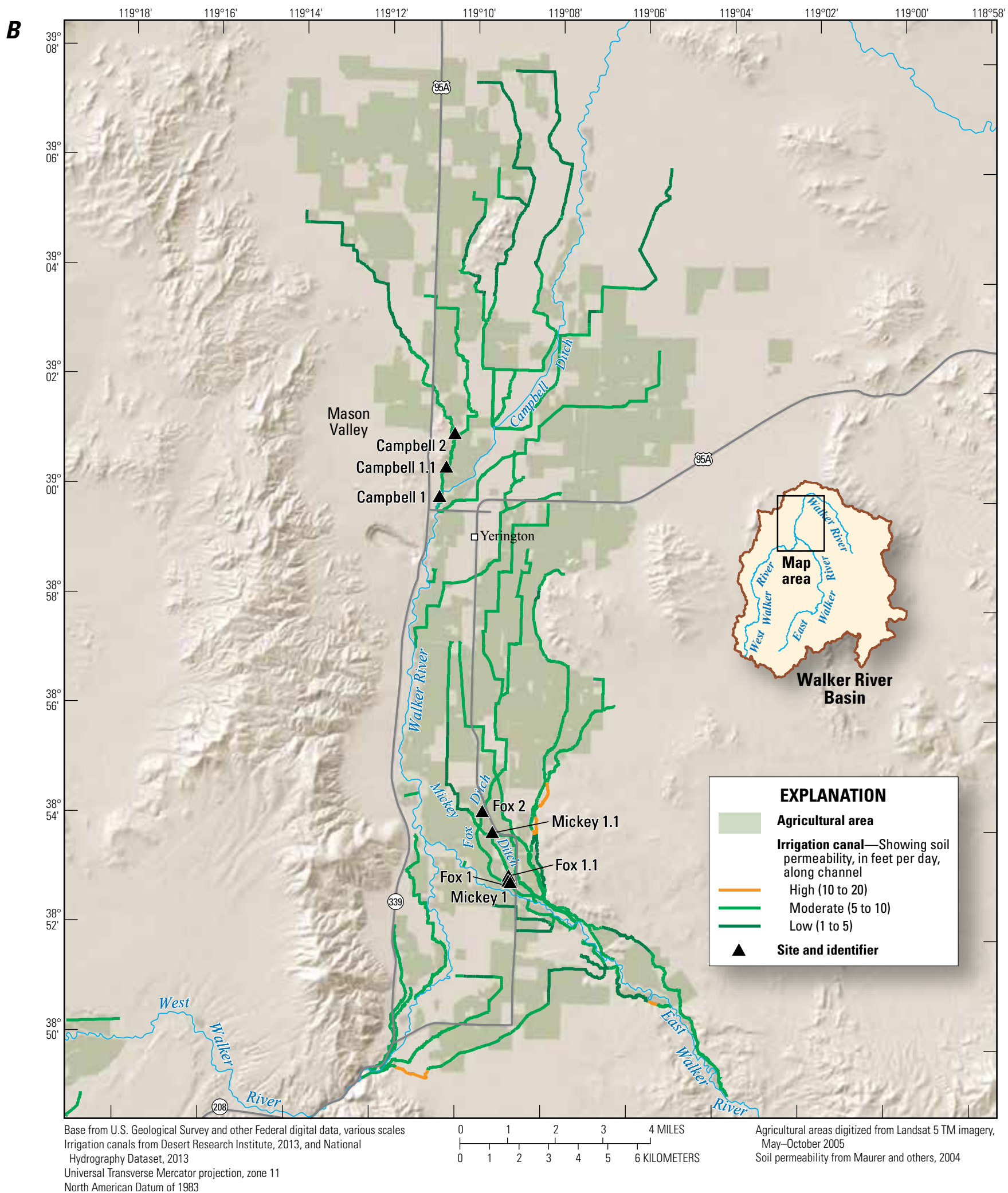

Figure 2. Soil permeability along irrigation canals in $A$, Smith Valley, $B$, Mason Valley, and $C$, Walker Lake Valley, Nevada. - Continued 


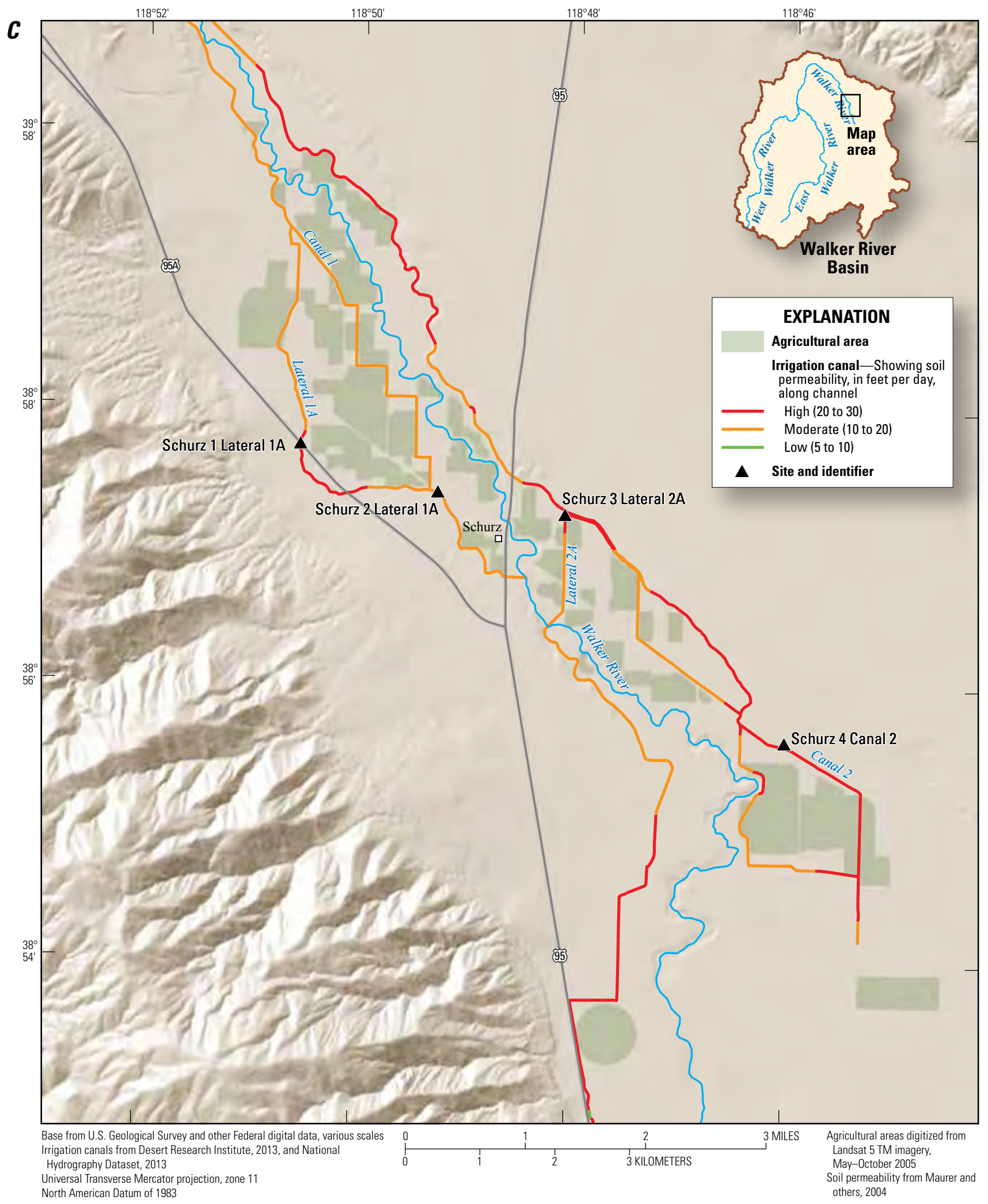

Figure 2. Soil permeability along irrigation canals in $A$, Smith Valley, $B$, Mason Valley, and $C$, Walker Lake Valley, Nevada.-Continued 


\section{Soil Permeability}

Seepage of water through soil is controlled by the hydraulic properties. Soil permeability in the Walker River Basin has been previously estimated by using mapped soil properties and landforms such as alluvial fan deposits, stream channels, valley floor alluvium, floodplain or lake deposits, or playa sediments (Maurer and others, 2004). Generalized classifications of soil permeability by Maurer and others (2004) were used to delineate the spatial distribution of soil permeability along canals (fig. $2 A-C$ ). The soils at lower altitudes such as in the Schurz HA are generally derived from granitic and volcanic parent material that consists of sandy loams and decomposed granite, and have higher infiltration rates than soils in the Smith and Mason HAs. Sandy loam is the most common texture in the valley, but rock content is commonly up to 35 percent, especially on steeper slopes (Maurer and others, 2004). Fine sediments with low hydraulic conductivity deposited in canals and subsurface heterogeneity are not considered in the permeability maps. Therefore, the dynamic behavior of soil development (siltation and scour) and canal maintenance done periodically to improve conveyance efficiency are important factors to consider in the estimation of permeability in irrigation canals.

\section{Water-Table Levels}

The use of groundwater has been historically relied on for agriculture as a supplement to surface water during dry years. Regional water-table altitude maps interpolated by observed data from monitoring wells in the Walker River Basin were used to construct depth-to-water surface maps along irrigation canals (Lopes and others, 2006). The depth-to-water maps along canals were made by subtracting the water-table altitude from the canal-surface altitude. The distances to the shallow aquifer from the base altitudes of canals help to emphasize the extent of hydraulic connectivity between the canals and the shallow aquifer system (fig. 3), although in some areas of the basin, groundwater altitudes can change seasonally as a result of groundwater pumping and irrigation recharge. This affects the depth to water beneath the irrigation canals and the seepage rates by changing the hydraulic gradient between surface water and groundwater. The depth to water in the Smith Valley irrigation canals is greater at higher land-surface altitudes near the base of hillslopes near the mouth of Hoye Canyon and along the valley south of the West Walker River (fig. 3A). In Mason Valley, the segments of canals near the river are among the shallowest, with less than $10 \mathrm{ft}$ to the water table for most of the canals south of Yerington (fig. $3 B$ ). The depth to the water table increases in canals north of Yerington as a result of irrigation pumping and land-surface altitude, with sections of canals greater than $10 \mathrm{ft}$ to the water table. In the Walker Lake Valley irrigation canals, the depth to groundwater is greater than $16 \mathrm{ft}$ even in those canals closest to the Walker River (fig. 3C).

\section{Methods of Investigation}

The methods described in this report have been applied to selected irrigation canals in Smith Valley, Mason Valley, and Walker Lake Valley on the WRPIR. Direct approaches for measuring seepage losses such as differencing measured flow (inflow-outflow) at two points in the canal, or ponding experiments, were deemed costly and uncertain due to measurement error and unsteady flow (for example, Alam and Bhutta, 2004; Martin and Gates, 2014). In this study, the collection of instantaneous flow measurements for seepage estimates was impractical given the number of diversions and return flows along a canal reach and temporally varying canal flow. The seepage rate can also be influenced by the water table in hydraulically connected canals. At each transect study site, hourly temperature and water-level data were used as inputs to the variably saturated heat transport model VS2DH (Healy and Ronan, 1996; Hsieh and others, 2000) to indirectly estimate continuous seepage losses by adjusting hydraulic and thermal properties to match observed temperatures. This indirect approach is more advantageous as measurements can be obtained without disrupting irrigation schedules, and temperature, a natural tracer, is relatively inexpensive to measure. The seepage estimates are based on simulating heat advection and conduction using observed temperature data as calibration targets. In hydraulically connected canals, continuous head data from bank piezometers and monitoring wells were included in the seepage estimation. Lithologic descriptions and depth of sediment cores taken from each canal transect are provided for qualitative comparisons to textural properties assigned during model calibration (appendix 4). The parameters used in the VS2DH transect models are provided in appendix 5. Data collection for this study began in April 2012 and was completed in November 2013 (appendix 6). Monitoring sediment temperatures over the irrigation period was done by using a newly developed temperature probe designed specifically for this investigation given the need for long-term continuous data during variable flow conditions.

\section{Field Data Collection}

The use of heat as a tracer for seepage estimation requires monitoring of the diel amplitude and attenuation of temperature at multiple depths below the canal, and monitoring of frequency and duration of flow in the canal. A temperature probe (referred to as TROD, after temperature rod) was developed by the USGS and Alpha Mach, Inc., to permit accurate, detailed, and systematic determinations of heat and water flux in variable sediment textures in the Walker River Basin. The TROD was designed to be low-profile and enables the user to retrieve data from the banks of canals through a communications cable (see description in Naranjo and Turcotte, 2015). 


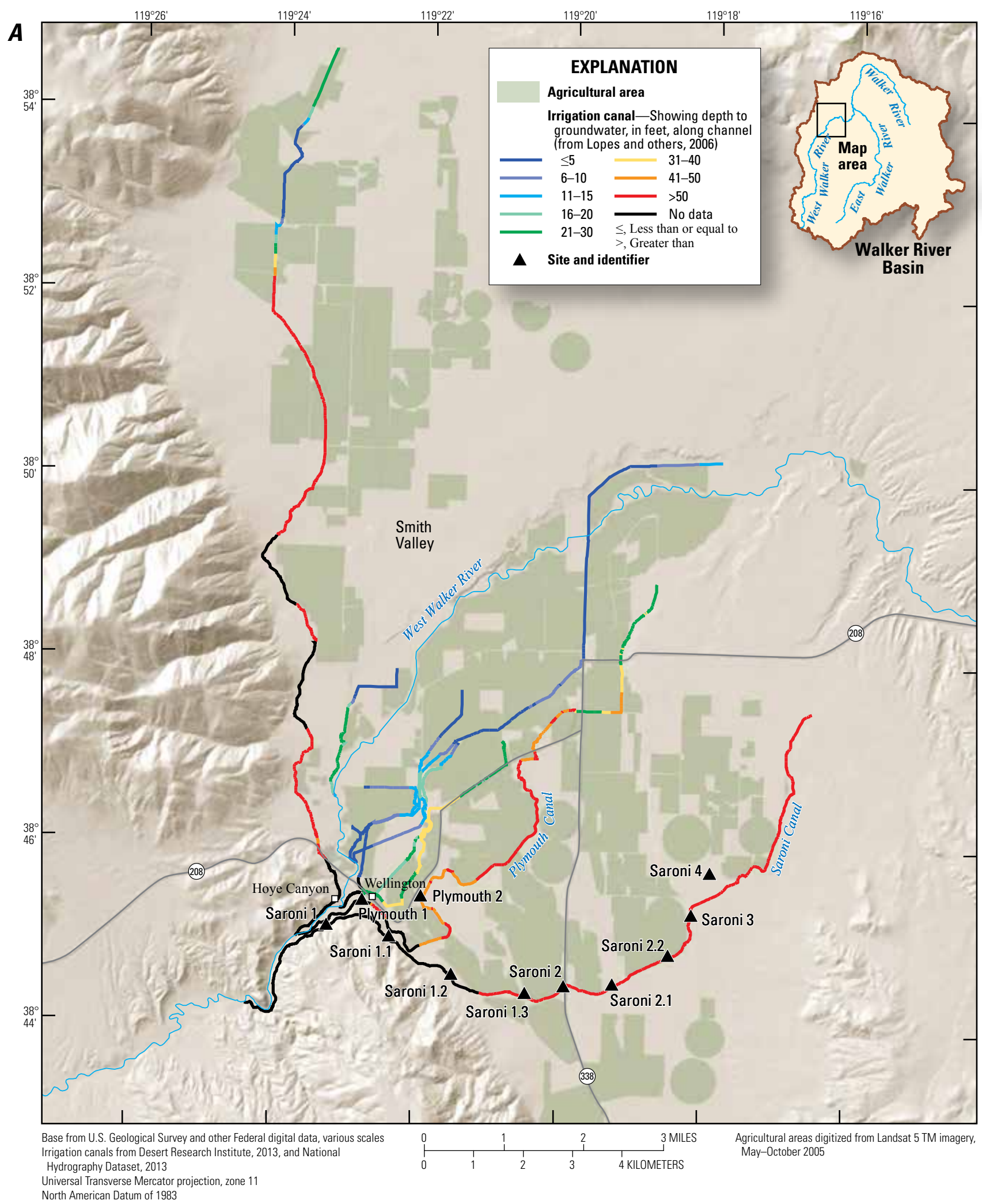

Figure 3. Depth to groundwater along irrigation canals in $A$, Smith Valley, $B$, Mason Valley, and $C$, Walker Lake Valley, Nevada. 


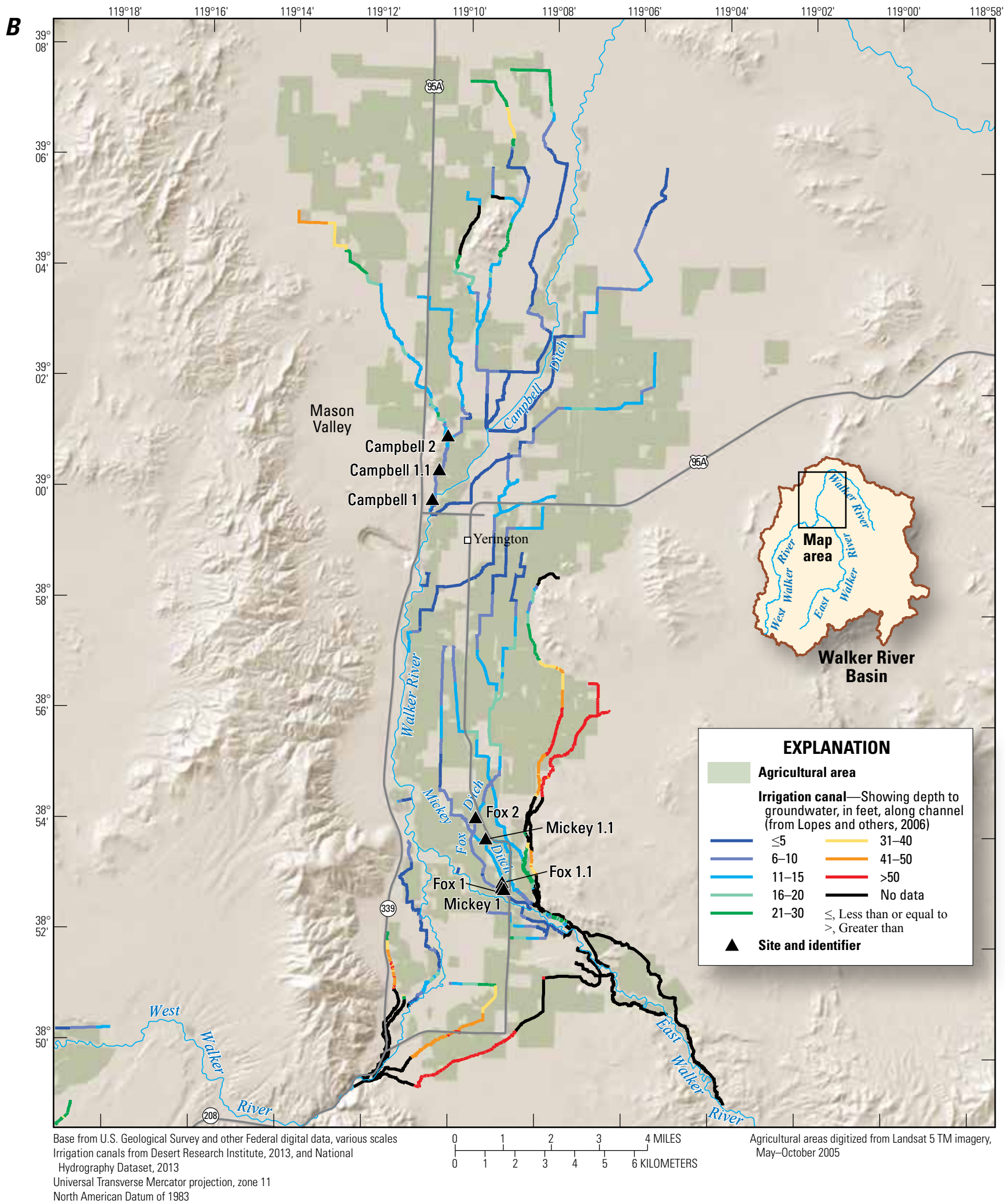

Figure 3. Depth to groundwater along irrigation canals in $A$, Smith Valley, $B$, Mason Valley, and $C$, Walker Lake Valley, Nevada.-Continued 


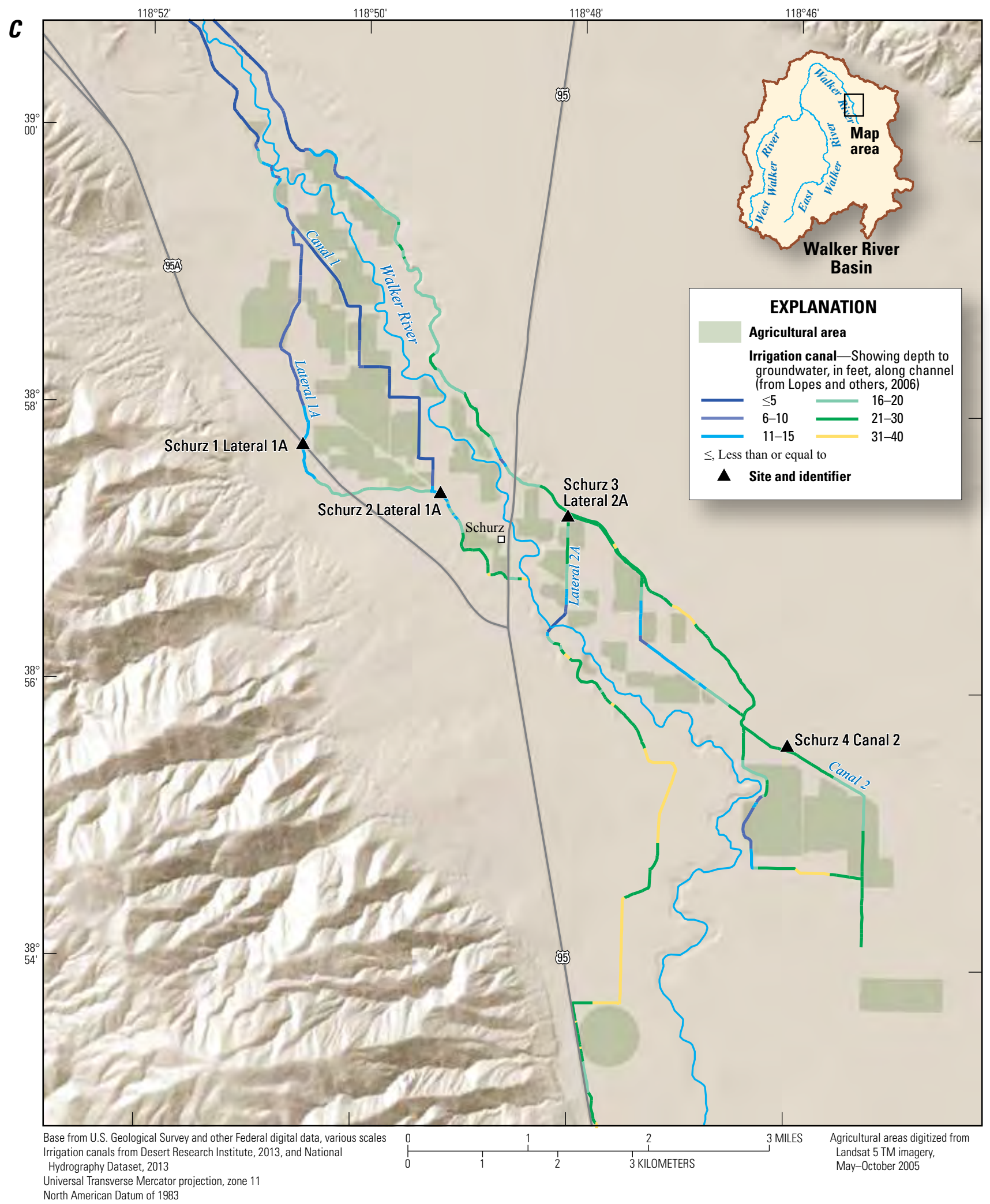

Figure 3. Depth to groundwater along irrigation canals in $A$, Smith Valley, $B$, Mason Valley, and $C$, Walker Lake Valley, Nevada. -Continued 
The installation of equipment was similar for each transect where TRODs were installed in the channel and along the bank to monitor sediment temperature gradients (fig. 4). In the center of the channel, the temperature probes consist of a sensor array 1.0-meter $(\mathrm{m})$ long with sensors spaced at $0,0.10$, $0.20,0.50,0.75$, and $1.0 \mathrm{~m}$, connected to a communications cable that allowed for downloading data along the canal bank without removing equipment to retrieve data. At transects with a bottom width greater than $1 \mathrm{~m}$, an additional temperature probe was installed to capture potential differences in thermal gradients and seepage. The temperature probes have a resolution of $0.125^{\circ} \mathrm{C}$, a range of -5 to $26^{\circ} \mathrm{C}$, an accuracy of $\pm 1.0^{\circ} \mathrm{C}$ and can store 2,048 measurements. The accuracy of the temperature probe was improved by calibration to $0.1^{\circ} \mathrm{C}$ as discussed below.

The installation of the TRODs into canal sediments involved piloting a hole with a 1 -in. diameter rock bar. The piloted hole was used to loosen sediments and to determine if the desired depth of $1.0 \mathrm{~m}$ was achievable given the presence of rocks in the subsurface. The piloted hole was filled with bentonite slurry to seal the area between the TROD and the sediments and to avoid preferential flow downward along the probe. The communications cable was buried in canal sediment to avoid debris entrainment and secured along the bank of the canal. During the first week of canal flow, data were downloaded and inspected for temperature anomalies associated with preferential flow.

Along the banks of the canals, piezometers were driven to a depth that varied between 1 and $2 \mathrm{~m}$ below the bottom altitude of the canal (fig. 4). The bank piezometers were constructed of 2.54-centimeter $(\mathrm{cm})$ diameter schedule 40 PVC pipe with a solid PVC drive point. A series of vertical holes were drilled through the pipe $0.2 \mathrm{~m}$ in length and $0.10 \mathrm{~m}$ from the drive point to allow water flow in and out of the piezometer (fig. 4). A string of three to four independent water-resistant temperature sensors (Alpha Mach, Inc. IBCOD

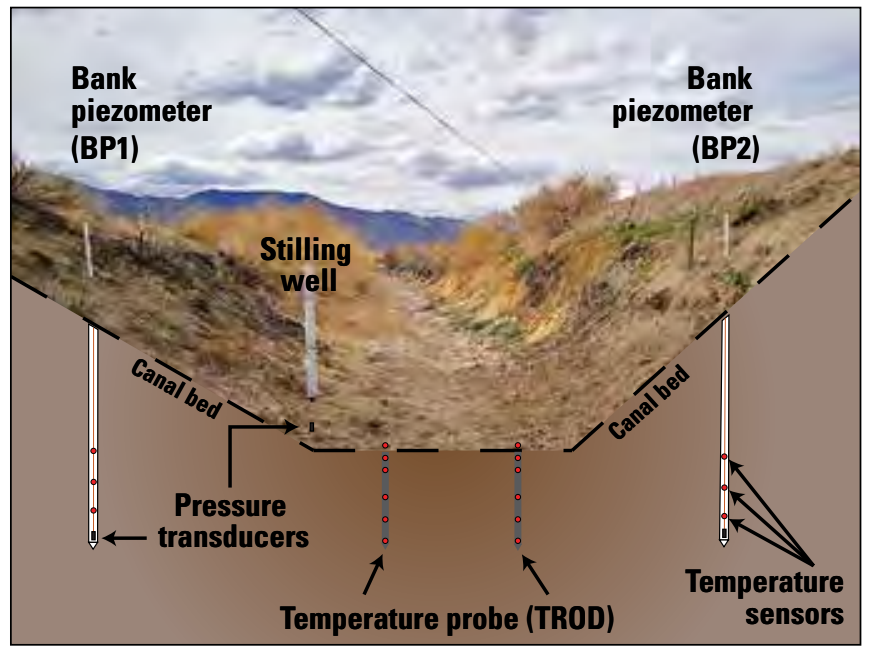

Figure 4. Instrumentation monitoring design for seepage estimation in the Walker River Basin, Nevada.
TYPE Z) were placed inside the piezometers to monitor the temperature gradients created by lateral seepage away from the canals. Soil temperature at the base of the piezometers slightly below the land surface was monitored by using similar type sensors (Alpha Mach, Inc. IBCOD TYPE L) for thermal gradients between the land surface and at depth inside the piezometers along the banks of the canals. In canals where the bank piezometers transected the water table, a Schlumberger Water Services Micro-Diver pressure transducer and temperature data logger was installed above the slotted interval on the piezometer.

Stage and temperature of the flowing water in the canal were monitored inside a stilling well by also using a Schlumberger Water Services Micro-Diver pressure transducer and temperature data logger. The data logger was placed near the bottom to capture the low flow but high enough to avoid contact with the ground surface (fig. 4). Periodic clearing of the sediment at the bottom of the stilling well was necessary to avoid build-up of sediment on the pressure transducer. The accuracy of the pressure transducer measurements is $\pm 1.0 \mathrm{~cm}$, with a resolution of $0.2 \mathrm{~cm}$. The temperature readings have an accuracy of $\pm 0.1^{\circ} \mathrm{C}$ and a resolution of $0.01{ }^{\circ} \mathrm{C}$.

Temperature and pressures were monitored every 30 minutes during the 2012 and 2013 agricultural seasons. Data were retrieved from data loggers on a monthly basis. Manual measurements of canal stage, and piezometer and monitoring well heads were taken to evaluate and correct pressure transducer readings. Barometric pressure was measured at three transects in Mason, Smith, and Walker Lake Valleys by using a Schlumberger Water Services Baro-Diver to compensate measured pressure for barometric fluctuations.

The accuracy of the temperature sensors was improved through calibration with a NIST-certified traceable digital thermometer with a resolution of $0.0001{ }^{\circ} \mathrm{C}$ and an accuracy of $0.05^{\circ} \mathrm{C}$ in a circulating water bath. Temperature sensors were evaluated at target bath temperatures of $5,10,15$, and $20^{\circ} \mathrm{C}$, and a linear regression equation was developed between the NIST thermometer readings and the individual temperature sensor values. The raw data from each temperature temperature sensor were then corrected by using each individual regression equation, which improved the accuracy from $\pm 1.0^{\circ} \mathrm{C}$ to $\pm 0.1{ }^{\circ} \mathrm{C}$. The corrected temperatures were then used for model calibration.

Two monitoring wells were constructed on the banks of the Campbell ditch (Campbell 1 and 2) to monitor the water table and its effects on canal seepage. Altitude data for each cross section, monitoring well, bank piezometer, and temperature sensor were obtained through level RTK GNSS survey techniques (Rylund and Densmore, 2012). The difference between the altitude of the water table and the canal stage, along with the hydraulic conductivity, which is dependent on soil moisture content, determines the extent of connectivity. 


\section{Canal Bed Soil and Texture Analysis}

Sediment cores were collected near the TRODs from 23 canal sites (appendix 4) to characterize the textures and depth variability of canal-bed sediments. Visual inspection of the canal sediment helped to describe the general extent of the soil zones used in the model, and core textural classification helped to identify the extent of layered deposits. For many of the canals, sharp contrasts in the soil types were visible through the soil coring tube with some sites having a distinct layering of coarse sands, and fine-silt and clay sediments. Results of particle size distribution and textural analysis at discrete changes in soils were differentiated into two groups, less than $0.25 \mathrm{~m}$ (shallow) and greater than $0.25 \mathrm{~m}$ (deep) depths, to further distinguish potential clogging layers near the sediment-water interface (fig. 5; appendix 4). Particle size analysis at discrete depths in the sample core tubes was done by the Colorado State University Soil Testing Laboratory (Fort Collins, Colorado) by hydrometer.

The majority of 34 soil cores from the Smith Valley canals were classified as a sandy clay loam texture; samples consisted of high percentages of sand ( 22 to 78 percent) and clay (16 to 48 percent), and low percentages of silt ( 0 to 14 percent) (fig. 5A; appendix 4). In the Saroni canal, the sandy clay loam texture was uniform at both depths, with the exception of that at the Saroni 1.2, 2.1, and 3 sites, where the soil contained high percentages of clay (44 to 48 percent) at the shallow depths. In the Plymouth canal, a clear distinction between depths was observed with the shallow canal soils classified as sandy clay loam, and the deeper soils classified as a lowpermeability clay texture.

Forty-six sediment cores collected from Mason Valley sites were classified primarily as sandy clay loam, although the core samples had a larger range of textural classification than the samples from Smith and Walker Lake Valleys (fig. 5B; appendix 4). The variability in textural classification is due to a higher concentration of silt ( 0 to 50 percent), whereas percent ranges of sand (4 to 79) and clay (16 to 56) are similar to those in Smith and Walker Lake Valleys. The soils in the Campbell and Mickey ditches generally had uniform sandy clay loam texture at shallow and deep depths, with the exception of the deep cores from the Campbell 1 and Mickey 1.1 sites. The sediments in the Fox ditch have an abrupt change in textural classification from sandy clay loam at shallow depths to an increase in silt composition (28 to 56 percent) at deep soil depths.

The majority of the 17 sediment cores from Walker Lake Valley were classified as sandy clay loam texture. The soil core composition of sand ( 28 to 78 percent), clay (21 to 48 percent), and silt (0 to 28 percent) was similar to that in cores collected from canals in Smith Valley (fig. 5C; appendix 4).

Soils from Lateral Canals 1A and 2A were generally uniform in texture and classified as a sandy clay loam for both shallow and deep depths. The cores from Canal 2 had a low-permeability clay composition for the shallow samples, whereas the deeper samples had a low silt composition characteristic of sandy clay loam.
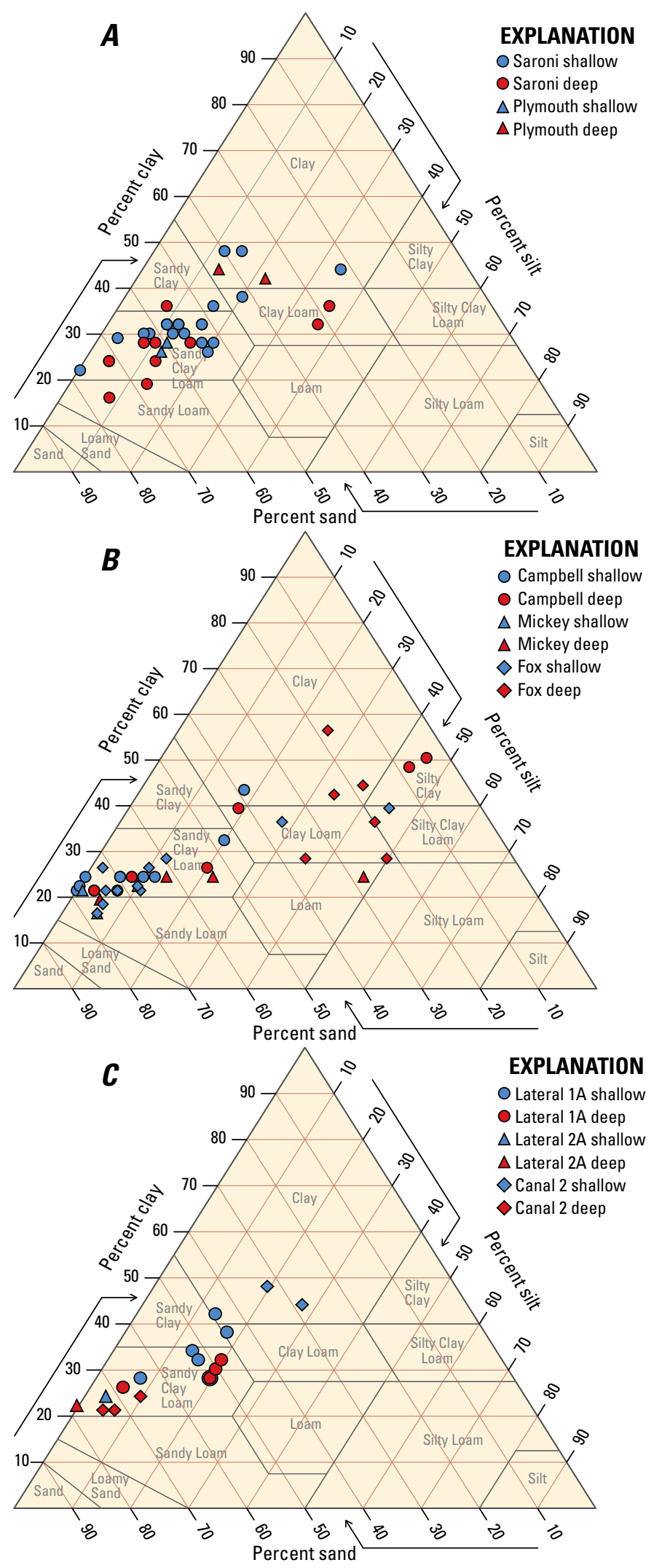

Figure 5. Soil core classifications for canal samples taken at transect sites in $A$, Smith Valley, $B$, Mason Valley, and $C$, Walker Lake Valleys, Nevada, as represented by compiling results into shallow (less than 0.25 meter) and deep (greater than 0.25 meter) zones. 


\section{Seepage Estimation Using Heat as a Tracer and Inverse Modeling (VS2DH)}

This section of the report describes the numerical methods used in estimating canal seepage rates. Included in this section is the model setup, rationale for soil textural class representation, model discretization, initial conditions, parameter sensitivity, and model calibration. The model used for estimation of seepage is a variably saturated two-dimensional groundwater flow model (VS2DH) that has been modified to simulate heat transport by advection and conduction, and uses the advection-dispersion equation to model energy transport (Healy and Ronan, 1996; Hsieh and others, 2000). VS2DH is a finite-difference model that uses a modified version of the advection-dispersion equation expressed in terms of water temperature (Healy and Ronan, 1996). The model simulates flow through the unsaturated zone by using a modified version of the Richards equation that assumes hydraulic conductivity is a temperature-dependent variable because of viscosity effects.

The use of heat as a natural tracer to estimate seepage across the sediment-water interface has been widely accepted because temperature, the measure of thermal energy, is easy to measure and relatively inexpensive to record. Moreover, natural thermal forcing at the land surface provides typically large diel signals in dry environments during the irrigation season. Heat tracer techniques have been used to estimate hydraulic and thermal properties of streambeds (Stonestrom and Blasch, 2003; Naranjo and others, 2012), quantify streambed scour (Tonina and others, 2014), quantify seepage losses in unlined agricultural canals (Mihevc and others, 2002; Hobza and Andersen, 2010; Shanafield and others, 2010) and ephemeral stream channels (Constantz and others, 2003), and evaluate recharge to aquifers (Taniguchi, 1993). For more examples using this technique, refer to extensive reviews by Stonestrom and Constantz (2003), Andersen (2006), Constantz and others (2008), and Rau and others (2014).

Canal seepage is affected by many factors, including depth to groundwater, canal flow depth and flow duration, and hydraulic conductivity of clogging layers. The hydraulic connection between the canal and the aquifer is important to measure as the infiltration rate is controlled by the head difference between the aquifer and the canal. Hydraulically connected systems can periodically become disconnected as a result of declining water tables (Brunner and others, 2009). The stages of connectivity are important to consider when measuring seepage losses as the rates may be influenced by the timing and occurrence of water-table declines by groundwater pumping. In hydraulically connected canals, the sediments beneath the canal are fully saturated, and the seepage rates are largely controlled by the dynamic behavior between changes in canal stage and the water table (fig. 6A). As the water table declines, an unsaturated zone develops beneath the canal, and the infiltration rate is no longer influenced by the water table and more controlled by the soil hydraulic properties and capillarity (fig. 6B). Further declines in the water table will result in an increase in thickness of the unsaturated zone, and the canal becomes hydraulically disconnected from the aquifer (fig. 6C). In this condition, the seepage rates are dependent on the depth of flow, hydraulic conductivity of the sediments, and the thickness of the clogging layer near the sediment-water interface (Brunner and others, 2009).

\section{Model Setup}

For each transect, a model was created by defining the model domain or cross-sectional representation of the canal, initial conditions, boundary conditions, and locations of observations (fig. 7). The physical characteristics of the model were based on a number of data types collected at each site, including soil cores, continuous water temperature, canal stage, cross-sectional survey altitude, and depth to the water table. The stage and temperature measured at the sedimentwater interface were specified as an upper boundary condition. The lateral and horizontal lower boundaries were specified as a total head boundary if the water table was measured in the bank piezometers. If the water table was lower than the depth of the piezometer, the lateral and lower horizontal boundaries were specified as a gravity drainage boundary condition. The two-dimensional VS2DH transect models were based on a parsimonious conceptual model consisting of an upper and lower zone. The upper zone represents soils near the sediment-water interface, and the lower zone represents a uniform homogeneous soil environment.

\section{Soil Textural Class Representation}

Canal sediments that represent the soil textural classes must be defined for each transect in the model domain. Textural classes associated with thermal and hydraulic properties are provided in the graphical user interface for VS2DH as a starting point in the parameterization process. These parameters are based on values reported in the literature (Carsel and Parrish, 1988). Parameters that define each zone of texture consist of hydraulic and thermal properties such as saturated hydraulic conductivity, porosity, the vertical to horizontal ratio of saturated hydraulic conductivity (hence referred to as the anisotropy), and the thermal conductivity at residual moisture content and at saturation. The units of hydraulic conductivity used in the model are in meters per hour $(\mathrm{m} / \mathrm{h})$, which requires thermal-conductivity values as reported in the literature to be converted for unit consistency from watts per meter-degrees Celsius $\left(\mathrm{W} / \mathrm{m}-{ }^{\circ} \mathrm{C}\right)$, an equivalent of joules per second per meter-degrees Celsius $\left(\mathrm{J} / \mathrm{s} / \mathrm{m}-{ }^{\circ} \mathrm{C}\right)$, to joules per hour per meterdegrees Celsius $\left(\mathrm{J} / \mathrm{h} / \mathrm{m}-{ }^{\circ} \mathrm{C}\right)$ (Richard Healy, U.S. Geological Survey, oral commun., 2012).

Near the sediment-water interface, some canal transects were indicated by an upper zone representing a clogging layer designed to limit the rate of infiltration into the model domain. This zone was assumed to have a lower permeability and ultimately control the rate of seepage. In some circumstances, two zones were delineated along the interface if two temperature probes were present. The sediment that represents the soil beneath this zone was also assumed to represent the general native soil and was defined to have a separate set of hydraulic and thermal properties. 
A

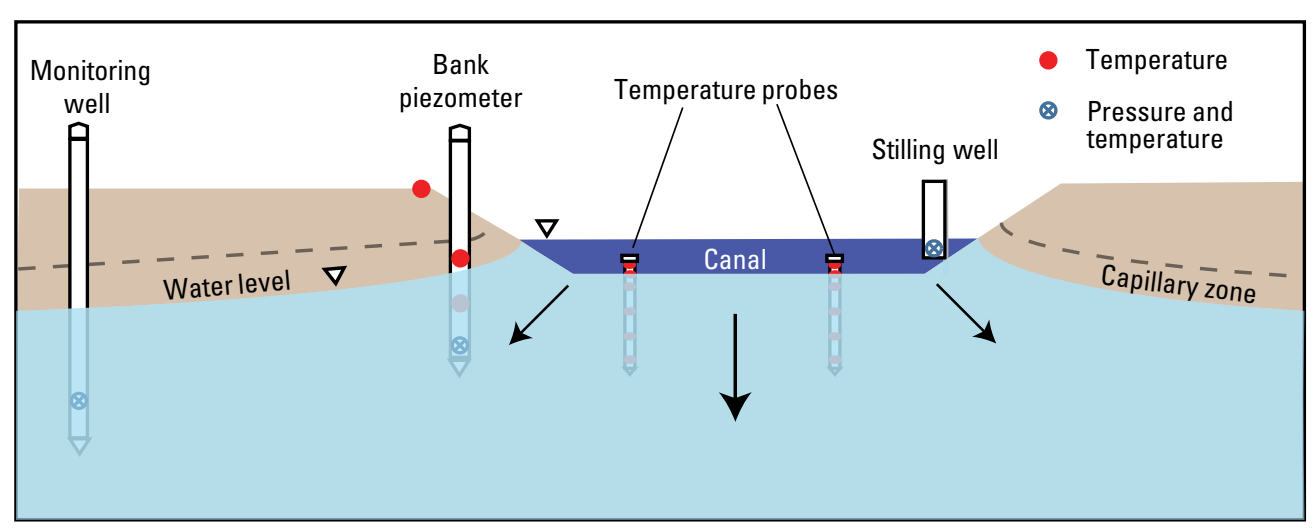

B

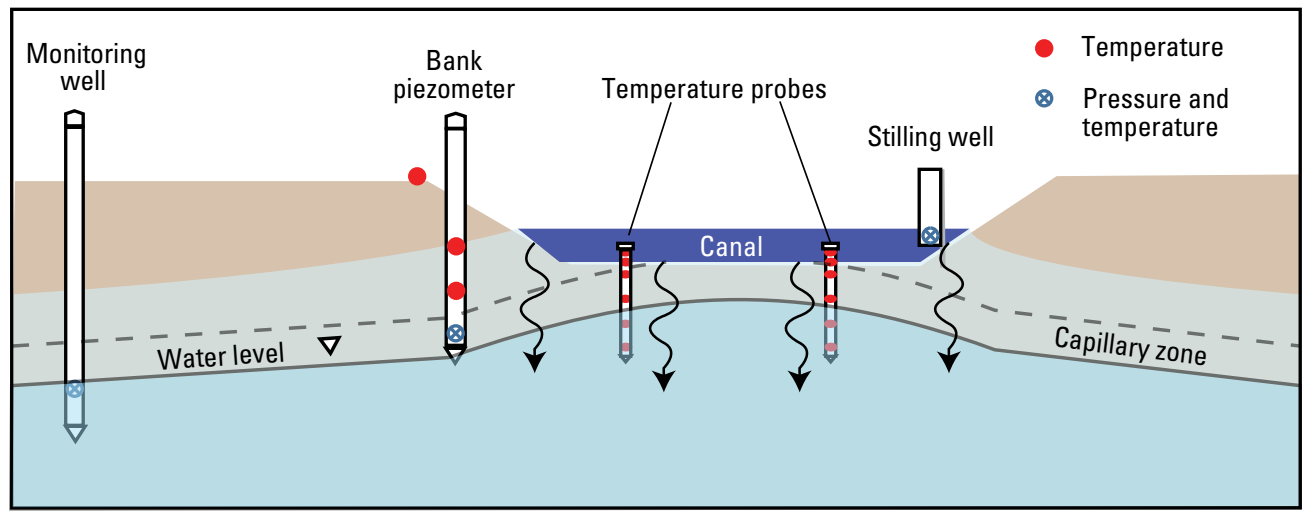

C

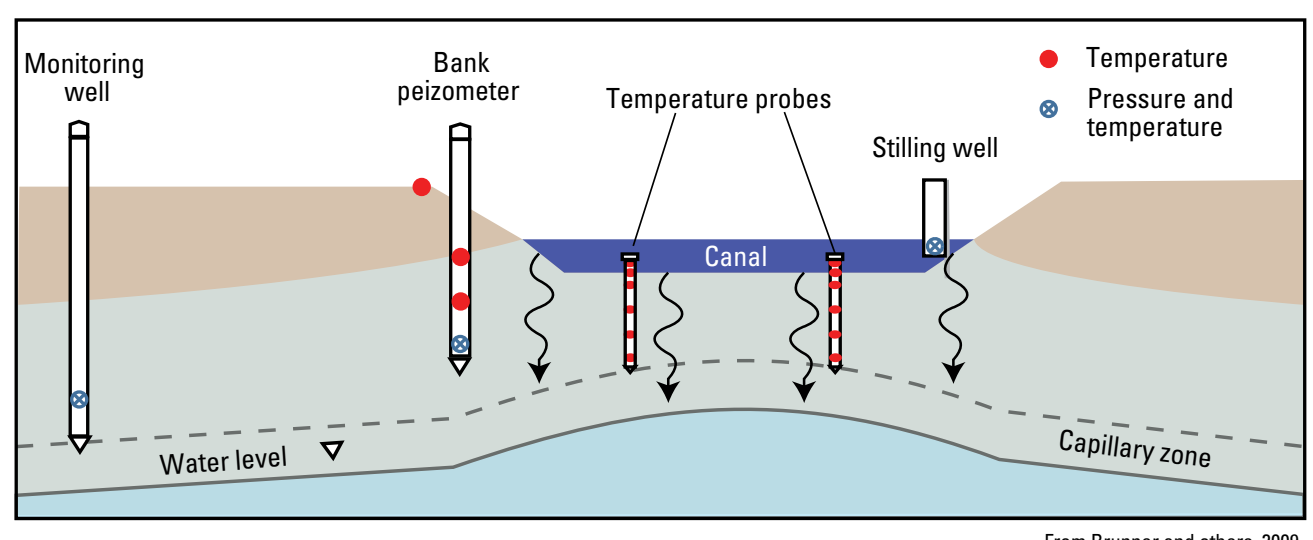

Percent saturation

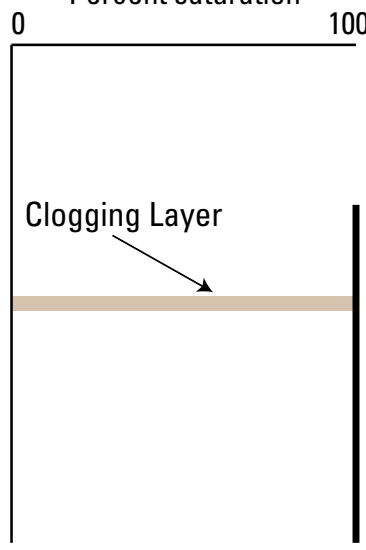

Percent saturation

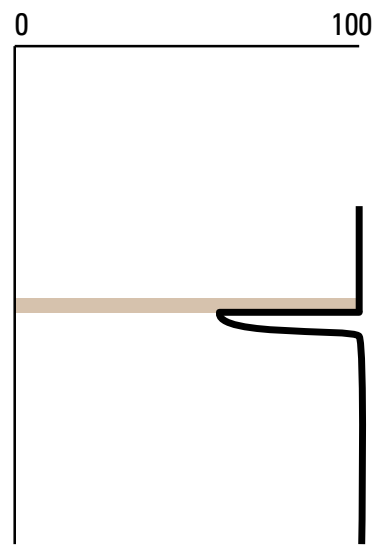

Percent saturation

0 100

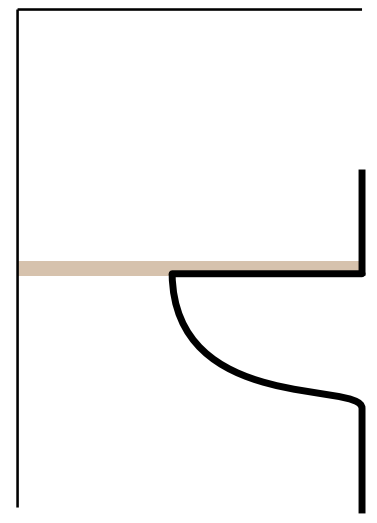

Figure 6. Array of temperature and pressure sensors in piezometers and wells in and adjacent to canals, and relative percent saturation of canal sediments in a $A$, hydraulically connected, $B$, transition, and $C$, disconnected canal. 


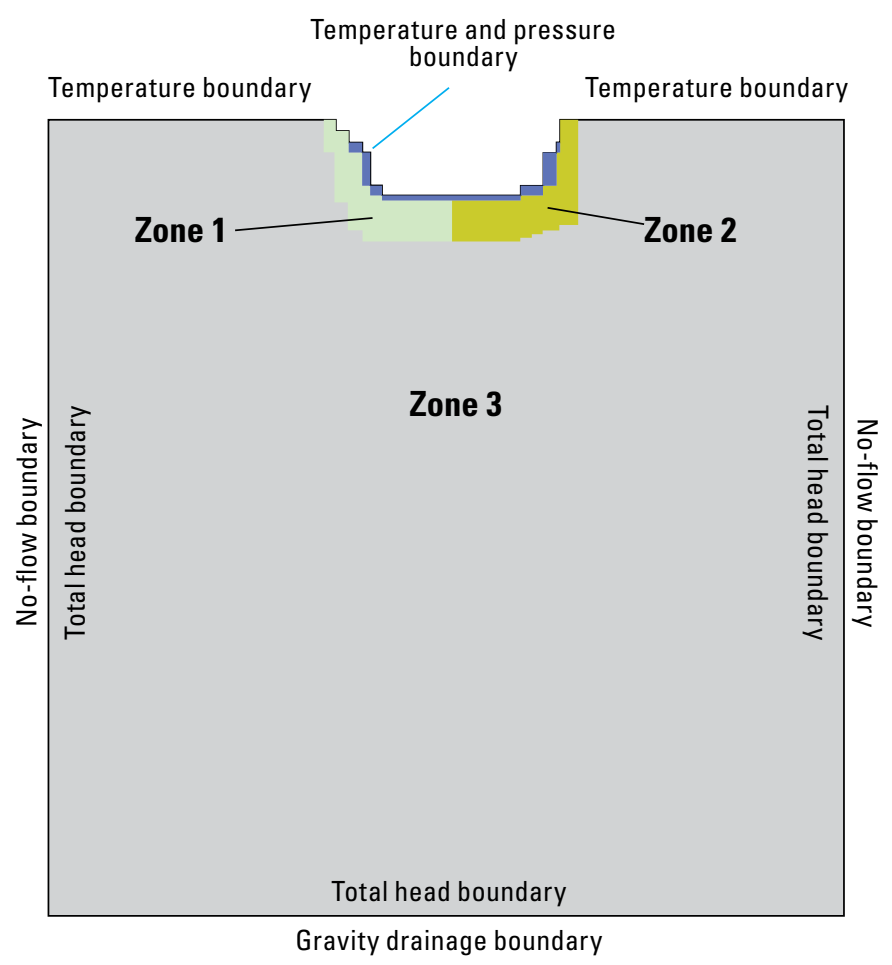

Figure 7. Generalized two-dimensional VS2DH model showing water and heat transport through canal-bed sediments. A no-flow and gravity drainage boundary was specified in hydraulically disconnected transect models, and a total head boundary condition was specified in hydraulically connected transect models.

\section{Model Discretization}

For each of the transect sites, each model represents a two-dimensional cross section of the canal oriented perpendicular to canal flow. The model grids defined in VS2DH have refined spacing near the canal boundary and temperature observations. Variable grid spacing was used in the horizontal direction between 0.2 and $1.0 \mathrm{~m}$ and in the vertical direction between 0.1 and $1 \mathrm{~m}$. The total model domain varied according to transect depending on canal width, location of bank piezometers, and depth to groundwater. The width and depth of the model domain varied for each model to avoid boundary condition edge effects on the simulations. The model extent in the horizontal and vertical direction varied between 20 and $50 \mathrm{~m}$, and 10 and $20 \mathrm{~m}$, respectively. Vertical boundaries along the sides of the models were placed at a distance that resulted in no influence to model simulations.

\section{Initial Conditions}

The VS2DH transect models require initial conditions for the specification of the hydraulic condition used and the general thermal gradients of the model area. The initial hydraulic condition was specified as "initial moisture content" option, which allows the user to define the moisture content of the soils relative to the pore space of the material. The value specified for each model was defined by assuming moisture contents were slightly above the residual moisture content of the soil textures defined by the general soil database in VS2DH. The initial moisture content among the different cross-sectional models ranged from 0.05 to 0.15 for the upper zone near the sediment-water interface. The initial temperature for each model was based on the interpolation of the observed temperature measurements at the start of the simulation.

\section{Parameter Sensitivity Analysis}

The value of a rigorous sensitivity analysis is to help identify sensitive parameters and their influence on predictions, determine the number of parameters needed for the formal parameter estimation procedure, and possibly guide the need for additional data collection. Reducing the number of parameters simplifies the calibration procedure and also makes the simulations run more efficiently. Sensitivity of individual parameters was tested by adjusting values by 25,50 , and 75 percent from a calibrated model and within the feasible parameter range for saturated hydraulic conductivity in the horizontal direction (Kh), porosity (Por), van Genuchten Alpha (VG Alpha) and Beta (VG Beta), longitudinal dispersion (DL), soil heat capacity (Cs), and thermal conductivity at residual moisture content (Ktr) and at saturation (Kts). The ratio of vertical to horizontal hydraulic conductivity, or anisotropy ratio $(\mathrm{Kz} / \mathrm{Kh})$, was specified as 1.0 or assumed isotropic conditions. This was justified to evaluate the relative contribution of hydraulic conductivity and thermal properties to the seepage rate and temperature simulations.

The baseline model used in the sensitivity analysis assumed a single uniform sandy loam texture. The feasible values of the VG Beta parameter do not vary beyond plus or minus 25 percent from the average value (1.89) of a sandy loam soil (appendix 5). Porosity of a sandy loam was initially assumed to be 0.40 and increases beyond 25 percent were not evaluated. The sensitivity of the individual parameters on the transport of heat was calculated by comparing the observed and simulated temperatures and calculating the percent bias (PBIAS). PBIAS is commonly used as an objective function that measures the average tendency of the simulated data to be more or less than the observed. Positive values of PBIAS indicate overestimation, and negative values indicate underestimation. The results clearly show the number of parameters that influence heat transport and may not necessarily influence seepage estimation (fig. 8). The Kh parameter is the most important and sensitive parameter in estimating heat transport and seepage estimation as indicated by the linear response to adjustments. Other parameters such as Por, Kts, and Cs only influence heat transport. The retention parameter VG Alpha is sensitive to the seepage estimation at adjustments greater than -50 percent from a sandy loam (1.88 to 3.75 per meter). Based on the results of the sensitivity analysis, the parameters used in the PEST optimization simulations were Kh, Ktr, Kts, and $\mathrm{Kz} / \mathrm{Kh}$. The $\mathrm{Kz} / \mathrm{Kh}$ parameter was included in the parameter estimation process to simulate anisotropic conditions in transect models. 


\section{Model Calibration Using PEST}

Once initial hydraulic and thermal properties for the transect models have been defined, model calibration is performed to refine the most sensitive parameter values. This is typically achieved by manual adjustments to parameters or through the use of separate programs designed to automate the process by making comparisons. In this study, the model was calibrated by using PEST (Parameter ESTimation; Doherty, 2007) code to refine the initial estimates for $\mathrm{Kh}, \mathrm{Kz} / \mathrm{Kh}, \mathrm{Ktr}$, and Kts for each of the textural classes or zones in the VS2DH transect models. PEST is an independent model that executes the VS2DH model and adjusts the model parameters using the Gauss-Marquardt-Levenberg optimization algorithm (Doherty, 2007) by comparing the simulated temperatures to the observed through a weighted least-squares objective function. PEST automatically re-runs the VS2DH model until the objective function is minimized and provides the final set of estimated parameters. PEST allows the use of observation and time varying weights to allow greater importance to data points or specific behaviors in the data such as daily fluctuations of temperature. To emphasize the daily minimum and maximum temperatures, the observations near the sedimentwater interface were given non-zero weights to avoid simulating temperatures that approximated the average temperatures. Applying weights to the minimum and maximum daily temperatures assigns more emphasis on the amplitude of the temperature signal, which is directly related to the hydraulic and thermal properties of the soils. The time varying weights were defined by using a modified version of Series SEE (v1.12; Halford and others, 2012) with the Period Function on the $0.10 \mathrm{~m}$ observation of the temperature probe. The observed temperature data between the daily maximum and minimum were given a weight of zero. PEST allows the user to specify prior relations between the zones, called Regularization, to limit the numerical instability caused by parameter nonuniqueness. Regularization avoids overfitting (and instability therefrom) by penalizing complexity. This is achieved by defining a set of relations among the set of parameters estimated between zones that avoid large contrasts in heterogeneity, typically defined as the log difference equal to zero.

To help facilitate the parameter estimation process, manual calibration was performed for each transect based on 1,000 hours of canal flow to initialize the model parameters needed for the execution of PEST. Default values were specified for soil properties not estimated in PEST based on reported values in Carsel and Parrish (1988) for general soil textural classifications included in VS2DH. PEST was allowed to only adjust the most influential parameters that affect seepage. The parameter values and ranges used in PEST were derived from values reported in the literature (table 2). The $\mathrm{Kh}$ was allowed to adjust multiple orders of magnitude with an assumed $\mathrm{Kh} / \mathrm{Kz}$ ranging from 0.1 to 1 . The range in Kts was assumed to vary between organic matter and a general sand texture.
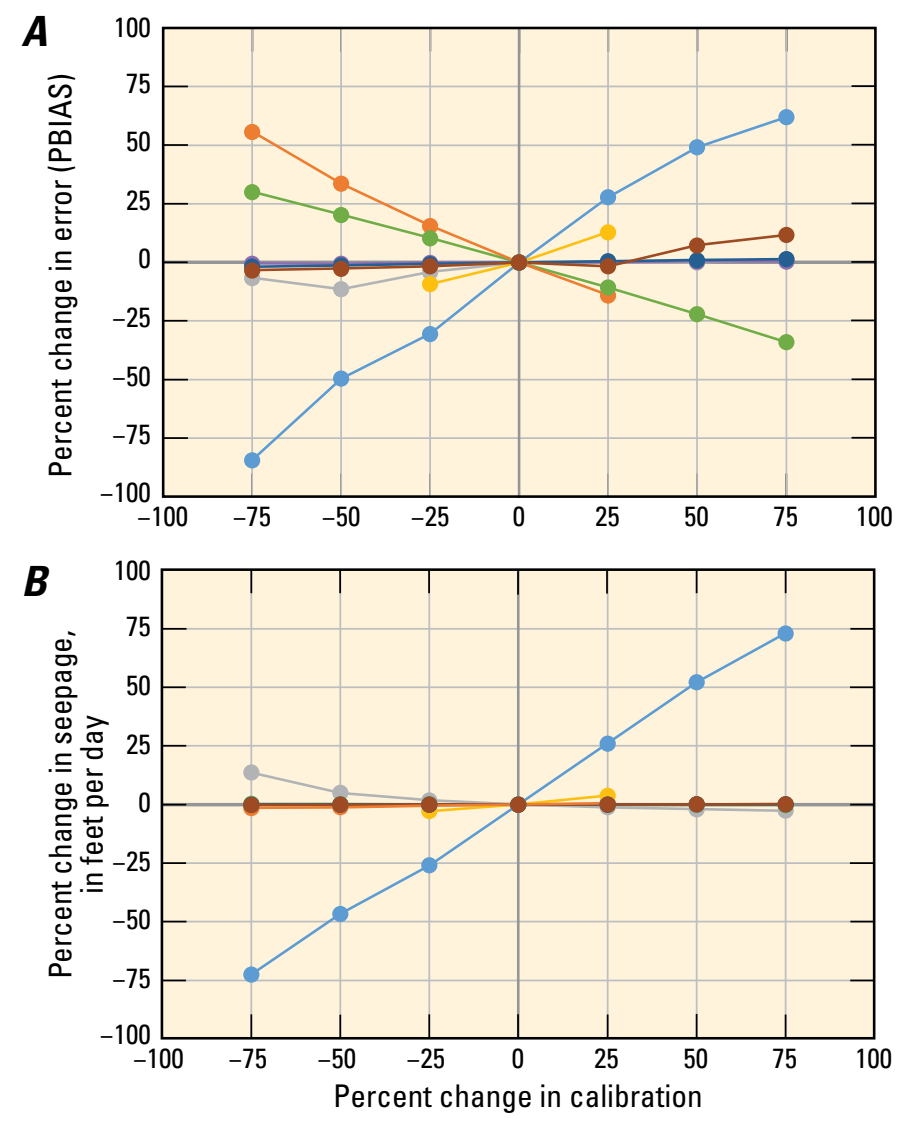

EXPLANATION

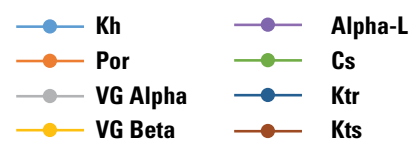

Figure 8. Sensitivity of hydraulic and thermal parameters to $A$, temperature error as indicated by percent bias (PBIAS), and $B$, canal seepage. Sensitivity of individual parameters was tested by adjusting values by 25,50 , and 75 percent within the feasible parameter range for saturated hydraulic conductivity in the horizontal direction. Saturated hydraulic conductivity (Kh), porosity (Por), van Genuchten Alpha (VG Alpha) and Beta (VG Beta), longitudinal dispersion (Alpha-L), soil heat capacity (Cs), and thermal conductivity at residual (Ktr) and at saturation (Kts).

The 2012 and 2013 irrigation seasons were divided into 60-minute intervals called recharge periods, each having unique upper and lower boundary conditions based on measured canal stage and water temperature data. Start date for model simulation periods for each temperature monitoring site was indicated for each irrigation season by a recorded rise in canal levels and change in thermal gradients induced by canal flow. 
Table 2. Summary of hydraulic and thermal parameters used as input into PEST to calibrate the VS2DH transect models.

\begin{tabular}{|c|c|c|c|c|}
\hline Parameter description & Symbol & Units & Values & Source \\
\hline \multicolumn{5}{|c|}{ Hydraulic parameters } \\
\hline Saturated horizontal hydraulic conductivity & $\mathrm{Kh}$ & $\mathrm{m} \mathrm{hr}^{-1}$ & $0.0001-10$ & Calibration \\
\hline Anisotropy & $\mathrm{Kz} / \mathrm{Kh}$ & - & $0.1-5.0$ & Calibration \\
\hline Saturated vertical hydraulic conductivity & $\mathrm{Kz}$ & $\mathrm{m} \mathrm{hr}^{-1}$ & $0.0001-10.0$ & $\mathrm{Kz}=\mathrm{Kh} *(\mathrm{Kz} / \mathrm{Kh})$ \\
\hline Porosity & $\mathrm{n}$ & - & $0.3-0.45$ & Carsel and Parrish $(1988)^{\mathrm{a}}$ \\
\hline Residual moisture content & $\mathrm{j}$ & - & $0.034-0.1$ & Carsel and Parrish (1988) \\
\hline van Genuthen Alpha & a & $\mathrm{m}^{-1}$ & $2-14.5$ & Carsel and Parrish (1988) \\
\hline van Genuthen Beta & $\mathrm{b}$ & - & $1.4-2.6$ & Carsel and Parrish (1988) \\
\hline \multicolumn{5}{|c|}{ Thermal parameters } \\
\hline Longitudinal dispersivity & $\mathrm{aL}$ & $\mathrm{m}$ & 0.01 & Niswonger and Prudic (2003) \\
\hline Transverse dispersivity & aT & $\mathrm{m}$ & 0.01 & Niswonger and Prudic (2003) \\
\hline Volumetric heat capacity & Cs & $\mathrm{J} \mathrm{m}^{-3}{ }^{\circ} \mathrm{C}^{-1}$ & $1.0 \times 10^{6}-1.3 \times 10^{6}$ & Niswonger and Prudic (2003) \\
\hline Thermal conductivity of sediments at residual moisture content & Ktr & $\mathrm{J} \mathrm{h}^{-1} \mathrm{~m}^{-1}{ }^{\circ} \mathrm{C}^{-1}$ & $300-936$ & Calibration \\
\hline Thermal conductivity of saturated sediments & Kts & $\mathrm{J} \mathrm{h}^{-1} \mathrm{~m}^{-1}{ }^{\circ} \mathrm{C}^{-1}$ & $300-9,720$ & Calibration \\
\hline
\end{tabular}

${ }^{a}$ Specified in each textural class within VS2DHI (Heish and others, 2000) as reported in Carsel and Parrish (1988).

\section{Modeling Results}

\section{PEST}

The parameters $\mathrm{Kh}, \mathrm{Kz} / \mathrm{Kh}$, Ktr, and Kts were optimized with PEST based on simulated and measured subsurface temperatures. The PEST estimates for Kh and Kts were the most variable between transects (appendix 5). A single set of model inputs was chosen for each textural class for the entire irrigation period or prediction period, extending from the model calibration period ( 1,000 hours) to the duration of canal flow during 2012 to 2013 except for the Saroni canal where siltation was significant. Prior to the 2012 agricultural season, routine maintenance on the Saroni canal was performed by heavy machinery where fine sediments were excavated and the canal was reshaped into a trapezoid to improve flow conveyance. At the end of 2012, deposition of fine sediments or siltation in the canal reduced the permeability of the sediments, which was evident in the VS2DH model's inability to match temperatures during the 2013 water year with fixed parameters from model calibration during 2012. Therefore, additional model calibration was completed on Saroni sites 1-4 during 2013. Although it is possible that siltation occurred in other canals during the 2012 season, the residual error computed for the 2013 season for other transects was not significant enough to warrant recalibration. Therefore, no other transect sites required recalibration based on the comparable residual errors between the 2012 and 2013 simulation periods.

\section{VS2DH Modeling}

The objective of model calibration was to simulate the thermal amplitude of canal sediments while matching longterm trends and thermal gradients caused by seasonal changes. Each transect was represented by a simple conceptual model of the subsurface sediments. Comparisons between measured and simulated subsurface temperatures are the primary indication of model accuracy, and during the calibration period, the transect models capture the diel temperature signal reasonably well. Larger errors in model simulations were likely caused by several factors, namely changes in permeability resulting from scour or siltation, and during intermittent periods of canal flow. Wetting and drying of canal sediments influence the heat transport in canal sediments by gravity drainage and evaporation. Simulated and observed temperatures for each transect are provided in appendixes $1 \mathrm{~A}-3 \mathrm{C}$ along with residual error, or the difference between the observed and simulated temperature for each simulated hour in 2012 and 2013.

A measure of the goodness of fit or root mean square error (RMSE) between simulated and observed temperatures for each observation depth was calculated to indicate how well the model simulates observed temperatures at each observation during the calibration and prediction periods (table 3 ). The median RMSE values for calibration range from 0.35 to $0.76{ }^{\circ} \mathrm{C}$ for all transect models. The median RMSE values increase from 0.46 to $1.41^{\circ} \mathrm{C}$ during the prediction period due to changes at the sediment-water interface from processes such as siltation or scour and during periods of intermittent canal flow. The transect models tend to poorly simulate the temperature observations along the canal bank piezometer locations during the calibration period as a consequence of the slow 
Table 3. Summary statistics of the calculated root mean square error (RMSE) and percent bias (PBIAS) for the calibration and prediction periods.

[Abbreviation: ${ }^{\circ} \mathrm{C}$, degrees Celsius; \%, percent]

\begin{tabular}{|c|c|c|c|c|c|c|}
\hline & \multicolumn{6}{|c|}{ Depth, in meters below canal bottom } \\
\hline & 0.1 & 0.2 & 0.5 & 0.75 & 1.0 & Bank piezometers \\
\hline \multicolumn{7}{|c|}{ Calibration RMSE ( $\left.{ }^{\circ} \mathrm{C}\right)$} \\
\hline Minimum & 0.1 & 0.1 & 0.1 & 0.1 & 0.1 & 0.1 \\
\hline Median & 0.4 & 0.4 & 0.4 & 0.4 & 0.5 & 0.8 \\
\hline Maximum & 1.0 & 1.1 & 1.3 & 1.2 & 1.1 & 4.8 \\
\hline \multicolumn{7}{|c|}{ Calibration PBIAS (\%) } \\
\hline Minimum & -6 & -3 & -11 & -5 & -4 & -46 \\
\hline Median & 0.2 & 0.2 & -0.5 & -0.3 & -0.1 & -0.6 \\
\hline Maximum & 3 & 4 & 3 & 2 & 2 & 26 \\
\hline \multicolumn{7}{|c|}{ Prediction RMSE $\left({ }^{\circ} \mathrm{C}\right)$} \\
\hline Minimum & 0.1 & 0.1 & 0.1 & 0.2 & 0.2 & 0.5 \\
\hline Median & 0.5 & 0.6 & 0.6 & 0.7 & 0.7 & 1.4 \\
\hline Maximum & 1.5 & 1.7 & 1.8 & 2.0 & 2.0 & 5.9 \\
\hline \multicolumn{7}{|c|}{ Prediction PBIAS (\%) } \\
\hline Minimum & -3 & -4 & -10 & -11 & -9 & -33 \\
\hline Median & 0.5 & 0.6 & 0.0 & 0.7 & 0.8 & -0.1 \\
\hline Maximum & 3 & 4 & 5 & 7 & 9 & 25 \\
\hline
\end{tabular}

lateral movement of soil moisture not necessarily arriving at the bank piezometers during the 1,000 hours of calibration. That is, at some transects, more than 1,000 hours would have been necessary to estimate sediment hydraulic and thermal properties of bank sediments based on temperature patterns alone due to the slow movement of the lateral wetting front.

For each transect, the models were calibrated during 1,000 hours of canal flow, and heat transport was more influenced by hydraulic and thermal conductivity. During the prediction period, many of the canals had periods of intermittent flow, causing the heat transport model to become very sensitive to other parameters not used in the calibration process such as retention properties, and van Genuchten Alpha and Beta parameters. Included in table 3 are the calculated RMSE and PBIAS values during the calibration and prediction periods, which include intermittent periods of no flow. The time series of residual errors during the prediction period, observed stage, and the estimated seepage are provided in appendixes 1A-3C. Further improvements to model performance could have been achieved by estimating retention properties in PEST or by calibration of multiple periods during the agricultural season as done on the Saroni canal. The improvements to model performance were not necessary during periods of no flow because this effort would not have resulted in improved estimates of seepage, and estimating changes in permeability (hydraulic conductivity) is beyond the scope of this work.

Canal seepage rates are directly related to the magnitude of the vertical and horizontal hydraulic conductivity of the soils. The layering of soils beneath canals will promote lateral subsurface flow and, in general, a reduction in vertical hydraulic conductivity as a function of depth is common where clay materials and alluvial deposits tend to facilitate subsurface flow in the horizontal direction. Anisotropy caused by layered sediments was predicted by PEST as transport simulations $(\mathrm{Kz} / \mathrm{Kh}$ less than 1.0) resulted in better fits with distinctly enhanced permeability in the horizontal direction at some sites (appendix 5).

Overall, the median hydraulic-conductivity values shown in table 4 for the study areas were between 0.001 and 0.03 meter per hour $(\mathrm{m} / \mathrm{h})$ and on the low end of the range reported for unconsolidated sediments along lower altitude alluvial slopes $(0.00025$ to $1.88 \mathrm{~m} / \mathrm{h}, 0.02$ to $140 \mathrm{ft} / \mathrm{d}$; Maurer and others, 2004, p. 6). The lower estimates of hydraulic conductivity are likely related to fine sediments deposited at the surface of the canals and subsurface layered deposits. As discussed earlier, the Saroni canal had undergone maintenance prior to the 2012 season where fine materials on the canal bottom were removed to improve conveyance. During the 2012 model calibration, the PEST model estimated an average hydraulic conductivity of $0.0022 \mathrm{~m} / \mathrm{h}$ in the upper sediments (zone 1) at Saroni 1 (appendix 5). After recalibration with 2013 observation data, the average hydraulic conductivity decreased by a factor of 20 to $0.00011 \mathrm{~m} / \mathrm{h}$. The reduction in hydraulic conductivity was discovered by evaluating the residual error between observed and simulated temperatures throughout the 2012 and 2013 seasons. By the end of 2012 and through 2013 , the residual errors were greater than $2.0^{\circ} \mathrm{C}$ in the shallow 0.10 - and $0.20-\mathrm{m}$ observations using a fixed set of model parameters from the 2012 calibration. Recalibration with 2013 data resulted in better fits to the observed data and lower estimates of hydraulic conductivity. 
Table 4. Median hydraulic and thermal conductivity of canal sediments estimated by PEST.

[Abbreviation: $\mathrm{m} \mathrm{hr}^{-1}$, meter per hour; $\mathrm{J} \mathrm{h}^{-1} \mathrm{~m}^{-1}{ }^{\circ} \mathrm{C}^{-1}$, joules per hour per meter per degree Celsius]

\begin{tabular}{|c|c|c|c|c|c|c|c|c|c|}
\hline \multirow{2}{*}{ Parameter } & \multirow{2}{*}{ Units } & \multicolumn{2}{|c|}{ Smith Valley } & \multicolumn{3}{|c|}{ Mason Valley } & \multicolumn{3}{|c|}{ Walker Lake Valley } \\
\hline & & Saroni & Plymouth & Mickey & Fox & Campbell & Lateral 1A & Lateral 2A & Canal 2 \\
\hline $\begin{array}{l}\text { Saturated horizontal hydraulic } \\
\text { conductivity }\end{array}$ & $\mathrm{m} \mathrm{hr}^{-1}$ & 0.004 & 0.001 & 0.03 & 0.03 & 0.02 & 0.008 & 0.03 & 0.004 \\
\hline Saturated vertical hydraulic conductivity & $\mathrm{m} \mathrm{hr}^{-1}$ & 0.002 & 0.001 & 0.03 & 0.01 & 0.008 & 0.008 & 0.03 & 0.02 \\
\hline $\begin{array}{l}\text { Thermal conductivity of saturated } \\
\text { sediments }\end{array}$ & $\mathrm{J} \mathrm{h}^{-1} \mathrm{~m}^{-1}{ }^{\circ} \mathrm{C}^{-1}$ & 3,456 & 3,780 & 9,720 & 9,720 & 5,364 & 2,077 & 2,302 & 4,986 \\
\hline
\end{tabular}

\section{Seepage Estimates}

The objective of the modeling was to estimate the seepage through canals at selected locations in the Walker River Basin. The seepage rate at every hourly time step in the model and the total seepage loss for each year are reported. A summary of the model simulation period, the number of days the canal was flowing, estimated seepage rates, and volume of loss for each transect for 2012-13 are provided in tables 5 and 6, respectively. Simulated seepage rates, canal stage, and residual error for each transect are provided in appendixes 1A-3C. The seepage losses for each transect were averaged for each year and summarized for the canal in table 7. Flow rates diverted into canals were not available to quantify the "percent loss"; however, the seepage rates are reported in units of feet per day (ft/d) and cubic feet per second per mile $\left(\mathrm{ft}^{3} / \mathrm{s}-\mathrm{mi}\right)$ of canal, and seepage loss is reported in acre-feet per mile per day (acre-ft/mi/d) and acre-feet per mile per agricultural year (acre-ft/mi/ag yr). Agricultural year is defined as the total number of days per year the canal had flow and was used to estimate the annual volume loss due to the reduction in water availability between 2012 and 2013. Simulated results for irrigation seasons 2012 and 2013 are shown in figure 9 for each of the transect sites.

\section{Smith Valley (Saroni and Plymouth Canals)}

The Saroni and Plymouth canals divert surface water from the West Walker River near the mouth of Hoye Canyon. The transect locations and the estimated seepage rates are shown in figure $9 A$. The Saroni and Plymouth canals are hydraulically disconnected from the aquifer and seepage rates were not affected by the position of the water table or regional groundwater pumping. The simulated and observed temperatures for the Smith Valley canals for the 2012 and 2013 irrigation seasons are shown in appendix 1A and 1B. During the 2013 irrigation season, additional transects were added to the Saroni canal (Saroni 1.1, 1.2, 1.3, 2.1, and 2.2). In 2013, the average number of irrigation days the canals had flowing water decreased to 125 from 190 in 2012 due to persistent drought conditions.

In 2012, the range of seepage from the Saroni canal was 0.02 to $1.6 \mathrm{ft} / \mathrm{d}(0.03$ to $0.6 \mathrm{ft} / \mathrm{s}-\mathrm{mi}$; table 5$)$. The highest rates of seepage were estimated at Saroni $4(1.6 \mathrm{ft} / \mathrm{d}$ or $0.4 \mathrm{ft} / / \mathrm{s}-\mathrm{mi})$,

Table 5. Seepage estimates for canal transect sites simulated in 2012 in Smith and Mason Valleys, Nevada.

[Abbreviation: $\mathrm{ft} / \mathrm{d}$, feet per day; $\mathrm{ft} / \mathrm{s}-\mathrm{mi}$, cubic feet per second per mile; acre-ft/mi/d, acre-feet per mile per day; acre-ft/mi/ag yr, acre-feet per mile per agricultural year; ${ }^{\circ} \mathrm{C}$, degrees Celsius; RMSE, root mean square error]

\begin{tabular}{|c|c|c|c|c|c|c|c|c|}
\hline \multirow{2}{*}{ Site name } & \multirow{2}{*}{ Date of simulation } & \multirow{2}{*}{$\begin{array}{l}\text { Simulation } \\
\text { period } \\
\text { (days) }\end{array}$} & \multirow{2}{*}{$\begin{array}{c}\text { Canal flow } \\
\text { (days) }\end{array}$} & \multicolumn{2}{|c|}{ Seepage rate } & \multicolumn{2}{|c|}{ Seepage loss } & \multirow{2}{*}{$\begin{array}{c}\mathrm{RMSE}^{\mathrm{a}} \\
\left({ }^{\circ} \mathrm{C}\right)\end{array}$} \\
\hline & & & & $(\mathrm{ft} / \mathrm{d})$ & $\left(\mathrm{ft}^{3} / \mathrm{s}-\mathrm{mi}\right)$ & (acre-ft/mi/d) & $\begin{array}{c}\text { (acre-ft/mi/ } \\
\text { ag yr) }\end{array}$ & \\
\hline \multicolumn{9}{|c|}{ Smith Valley } \\
\hline Saroni Canal 1 & $4 / 16 / 2012$ to $10 / 26 / 2012$ & 193 & 193 & 0.6 & 0.6 & 1.1 & 220 & 2.8 \\
\hline Saroni Canal 2 & $4 / 15 / 2012$ to $11 / 1 / 2012$ & 199 & 193 & 0.04 & 0.05 & 0.1 & 20 & 1.2 \\
\hline Saroni Canal 3 & $4 / 26 / 2012$ to $10 / 7 / 2012$ & 165 & 165 & 0.02 & 0.03 & 0.03 & 9 & 1.3 \\
\hline Saroni Canal 4 & $5 / 1 / 2012$ to $10 / 24 / 2012$ & 177 & 172 & 1.6 & 0.4 & 0.9 & 150 & 1.3 \\
\hline Plymouth Canal 1 & $3 / 23 / 2012$ to $10 / 26 / 2012$ & 217 & 217 & 0.2 & 0.1 & 0.2 & 40 & 0.8 \\
\hline Plymouth Canal 2 & $4 / 5 / 2012$ to $10 / 20 / 2012$ & 198 & 198 & 0.01 & 0.01 & 0.01 & 2 & 0.6 \\
\hline \multicolumn{9}{|c|}{ Mason Valley } \\
\hline Mickey Ditch 1 & $3 / 29 / 2012$ to $11 / 9 / 2012$ & 225 & 163 & 1.6 & 0.6 & 1.3 & 210 & 1.6 \\
\hline Fox Ditch 1 & $3 / 26 / 2012$ to $10 / 31 / 2012$ & 219 & 190 & 0.3 & 0.2 & 0.4 & 76 & 2.2 \\
\hline Fox Ditch 2 & $4 / 1 / 2012$ to $10 / 6 / 2012$ & 188 & 118 & 1.6 & 0.9 & 1.8 & 210 & 1.8 \\
\hline Campbell Ditch 1 & $3 / 26 / 2012$ to $10 / 31 / 2012$ & 220 & 172 & 0.15 & 0.2 & 0.4 & 60 & 1.5 \\
\hline Campbell Ditch 2 & $3 / 26 / 2012$ to $5 / 7 / 2012$ & 42 & 42 & 0.5 & 0.6 & 1.2 & 50 & 1.1 \\
\hline
\end{tabular}

\footnotetext{
${ }^{a}$ Calculated for entire model simulation period inclusive of dry periods and non-weighted.
} 
Table 6. Seepage estimates for canal transect sites simulated in 2013 in Smith, Mason, and Walker Lake Valleys, Nevada.

[Abbreviation: $\mathrm{ft} / \mathrm{d}$, feet per day; $\mathrm{ft} / \mathrm{s}-\mathrm{mi}$, cubic feet per second per mile; acre-ft/mi/d, acre-feet per mile per day; acre-ft/mi/ag yr, acre-feet per mile per agricultural year; ${ }^{\circ} \mathrm{C}$, degrees Celsius; RMSE, root mean square error; $>$, greater than; - , no data]

\begin{tabular}{|c|c|c|c|c|c|c|c|c|}
\hline \multirow{2}{*}{ Site name } & \multirow{2}{*}{ Date of simulation } & \multirow{2}{*}{$\begin{array}{c}\text { Simulation } \\
\text { period } \\
\text { (days) }\end{array}$} & \multirow{2}{*}{$\begin{array}{c}\text { Canal flow } \\
\text { (days) }\end{array}$} & \multicolumn{2}{|c|}{ Seepage rate } & \multicolumn{2}{|c|}{ Seepage loss } & \multirow{2}{*}{$\begin{array}{c}\mathrm{RMSE}^{\mathrm{a}} \\
\left.{ }^{\circ} \mathrm{C}\right)\end{array}$} \\
\hline & & & & $(\mathrm{ft} / \mathrm{d})$ & $\left(\mathrm{ft}^{3} / \mathrm{s}-\mathrm{mi}\right)$ & (acre-ft/mi/d) & (acre-ft/mi/ag yr) & \\
\hline \multicolumn{9}{|c|}{ Smith Valley } \\
\hline Saroni Canal 1 & $4 / 23 / 2013$ to $10 / 18 / 2013$ & 178 & 178 & 0.05 & 0.05 & 0.1 & 20 & 1.2 \\
\hline Saroni Canal 1.1 & $5 / 7 / 2013$ to $10 / 14 / 2013$ & 160 & 98 & 0.6 & 0.5 & 0.9 & 90 & 0.6 \\
\hline Saroni Canal 1.2 & $5 / 20 / 2013$ to $10 / 18 / 2013$ & 142 & 142 & 0.5 & 0.5 & 0.9 & 130 & 0.5 \\
\hline Saroni Canal 1.3 & $5 / 6 / 2013$ to $9 / 25 / 2013$ & 142 & 142 & 0.6 & 0.5 & 1.0 & 140 & 0.4 \\
\hline Saroni Canal 2 & $4 / 22 / 2013$ to $9 / 6 / 2013$ & 137 & 137 & 0.03 & 0.04 & 0.1 & 10 & 1.6 \\
\hline Saroni Canal 2.1 & $4 / 25 / 2013$ to $7 / 31 / 2013$ & 97 & 94 & 0.04 & 0.03 & 0.1 & 6 & 0.2 \\
\hline Saroni Canal 2.2 & $4 / 25 / 2013$ to $8 / 13 / 2013$ & 110 & 102 & 0.1 & 0.1 & 0.1 & 10 & 0.8 \\
\hline Saroni Canal 3 & $4 / 5 / 2013$ to $10 / 18 / 2013$ & 176 & 176 & 0.04 & 0.05 & 0.1 & 15 & 1.1 \\
\hline Saroni Canal 4 & $5 / 13 / 2013$ to $8 / 22 / 2013$ & 101 & 48 & 2.5 & 0.7 & 1.3 & 65 & 1.2 \\
\hline Plymouth Canal 1 & $3 / 20 / 2013$ to $7 / 26 / 2013$ & 129 & 129 & 0.2 & 0.1 & 0.2 & 24 & 0.8 \\
\hline Plymouth Canal 2 & $3 / 20 / 2013$ to $8 / 30 / 2013$ & 163 & 133 & 0.01 & 0.01 & 0.01 & 2 & 1.3 \\
\hline \multicolumn{9}{|c|}{ Mason Valley } \\
\hline Mickey Ditch 1 & $3 / 9 / 2013$ to $8 / 17 / 2013$ & 161 & 127 & 3.2 & 1.3 & 2.5 & 320 & 2.6 \\
\hline Mickey Ditch 1.1 & $4 / 10 / 2013$ to $9 / 28 / 2013$ & 171 & 109 & 3.3 & 1.3 & 2.6 & 290 & 0.9 \\
\hline Fox Ditch 1 & Moved to 1.1 & - & - & - & - & - & - & - \\
\hline Fox Ditch 1.1 & $5 / 4 / 2013$ to $8 / 14 / 2013$ & 102 & 59 & 1.7 & 1.0 & 2.0 & 120 & 2.0 \\
\hline Fox Ditch 2 & $3 / 27 / 2013$ to $9 / 6 / 2013$ & 163 & 102 & 1.6 & 0.9 & 1.8 & 180 & 1.8 \\
\hline Campbell Ditch 1 & $3 / 14 / 2013$ to $8 / 17 / 2013$ & 156 & 123 & 0.1 & 0.2 & 0.3 & 40 & 1.4 \\
\hline Campbell Ditch 1.1 & $5 / 5 / 2013$ to $7 / 12 / 2013$ & 67 & 67 & 1.8 & 0.6 & 1.2 & 80 & 0.3 \\
\hline Campbell Ditch 2 & Not simulated & - & - & - & - & - & - & - \\
\hline \multicolumn{9}{|c|}{ Walker Lake Valley } \\
\hline Schurz 1 Lateral 1A & $5 / 14 / 2013$ to $5 / 19 / 2013$ & 5 & $>5.0$ & 0.7 & 0.4 & 0.8 & $(\mathrm{~b})$ & 0.8 \\
\hline Schurz 2 Lateral 1A & $4 / 24 / 2013$ to $10 / 4 / 2013$ & 163 & 67 & 0.8 & 0.5 & 1.0 & 70 & 1.4 \\
\hline Schurz 3 Lateral 2A & $4 / 17 / 2013$ to $10 / 6 / 2013$ & 171 & 26 & 0.9 & 0.7 & 1.4 & 5 & 0.8 \\
\hline Schurz 4 Canal 2 & $4 / 15 / 2013$ to $10 / 6 / 2013$ & 173 & 95 & 0.8 & 1.3 & 2.6 & 240 & 0.6 \\
\hline
\end{tabular}

${ }^{\text {a }}$ Calculated for entire model simulation period inclusive of dry periods and non-weighted.

${ }^{\mathrm{b}}$ Can not estimate due to pressure transducer failure resulting in loss of continuous stage record.

Table 7. Annual average seepage loss for selected irrigation canals in Smith, Mason, and Walker Lake Valleys, Nevada.

[Abbreviation: acre-ft, acre-feet; acre-ft/mi/ag yr, acre-feet per mile per agricultural year; -, no data]

\begin{tabular}{|c|c|c|c|c|c|}
\hline \multirow{2}{*}{ Site name } & \multirow{2}{*}{$\begin{array}{l}\text { Length } \\
\text { (miles) }\end{array}$} & \multicolumn{2}{|c|}{$\begin{array}{c}2012 \\
\text { Average seepage loss }\end{array}$} & \multicolumn{2}{|c|}{$\begin{array}{c}2013 \\
\text { Average seepage loss }\end{array}$} \\
\hline & & $\begin{array}{l}\text { (acre-ft/ } \\
\text { mi/ag yr) }\end{array}$ & (acre-ft) & $\begin{array}{l}\text { (acre-ft/ } \\
\text { mi/ag yr) }\end{array}$ & (acre-ft) \\
\hline \multicolumn{6}{|c|}{ Smith Valley } \\
\hline Saroni Canal & 11 & 100 & 1,100 & 50 & 590 \\
\hline Plymouth Canal & 9.7 & 22 & 210 & 13 & 130 \\
\hline \multicolumn{6}{|c|}{ Mason Valley } \\
\hline Mickey Ditch & 7.3 & 200 & 1,500 & 300 & 2,200 \\
\hline Fox Ditch & 14.9 & 140 & 2,100 & 150 & 2,200 \\
\hline Campbell Ditch & 11.5 & 60 & 660 & 60 & 700 \\
\hline \multicolumn{6}{|c|}{ Walker Lake Valley } \\
\hline Schurz Lateral 1A & 3.0 & $(\mathrm{a})$ & - & $68^{\mathrm{b}}$ & 200 \\
\hline Schurz Lateral 2A & 1.5 & - & - & 35 & 50 \\
\hline Schurz Canal 2 & 3.0 & - & - & 240 & 725 \\
\hline
\end{tabular}

${ }^{a}$ Not measured.

${ }^{\mathrm{b}}$ Estimated using duration from Schurz 1 Lateral 1A. 


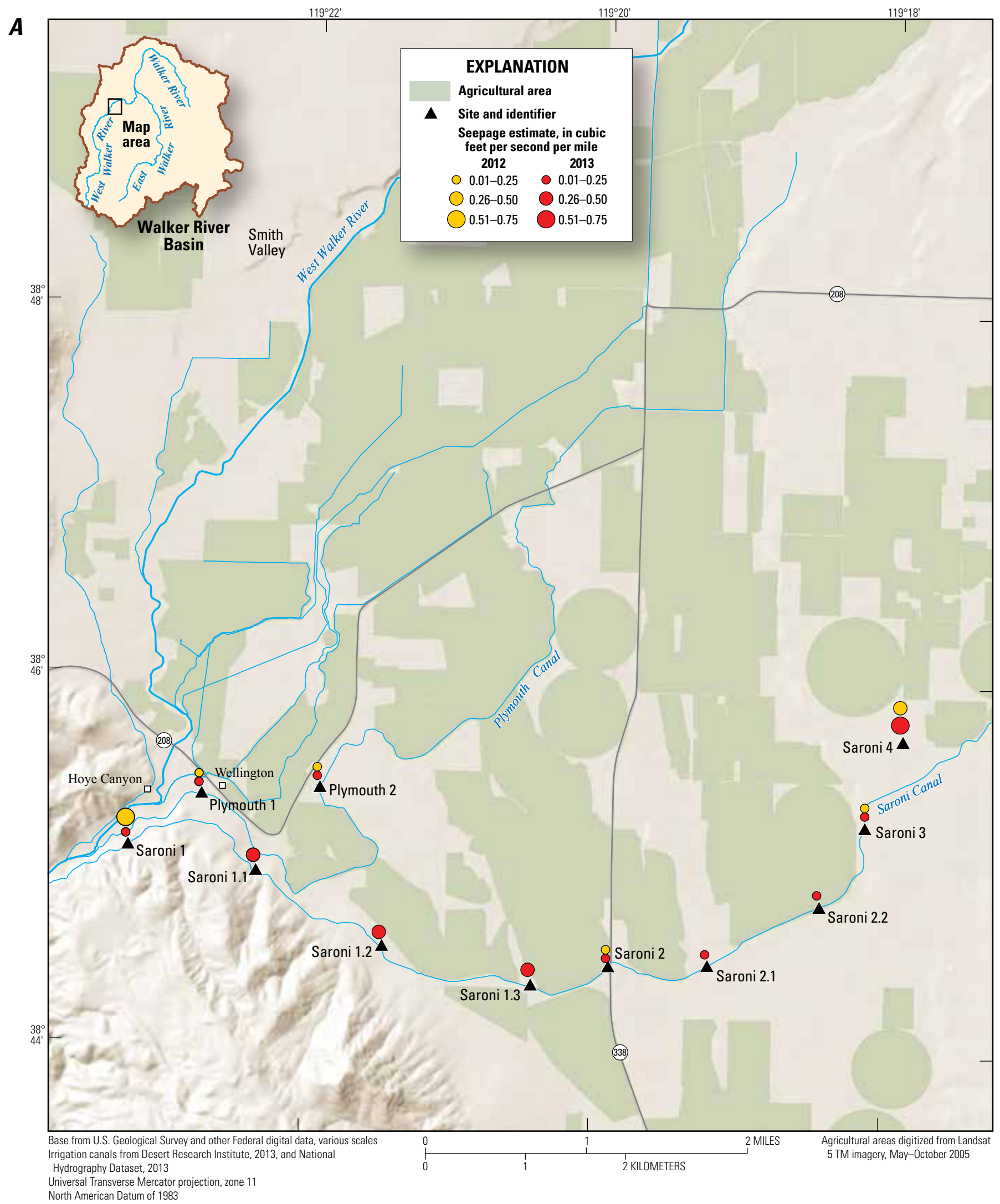

Figure 9. Estimated rates of seepage from selected irrigation canals in $A$, Smith Valley, $B$, Mason Valley, and $C$, Walker Lake Valley, Nevada. The following sites were instrumented in 2013 for seepage estimation: Smith Valley transect sites Saroni 1.1, 1.2, 1.3, 2.1, 2.2; Mason Valley transect sites Mickey 1.1, Fox 1.1, and Campbell 1.1; and all of the Walker Lake Valley sites. 


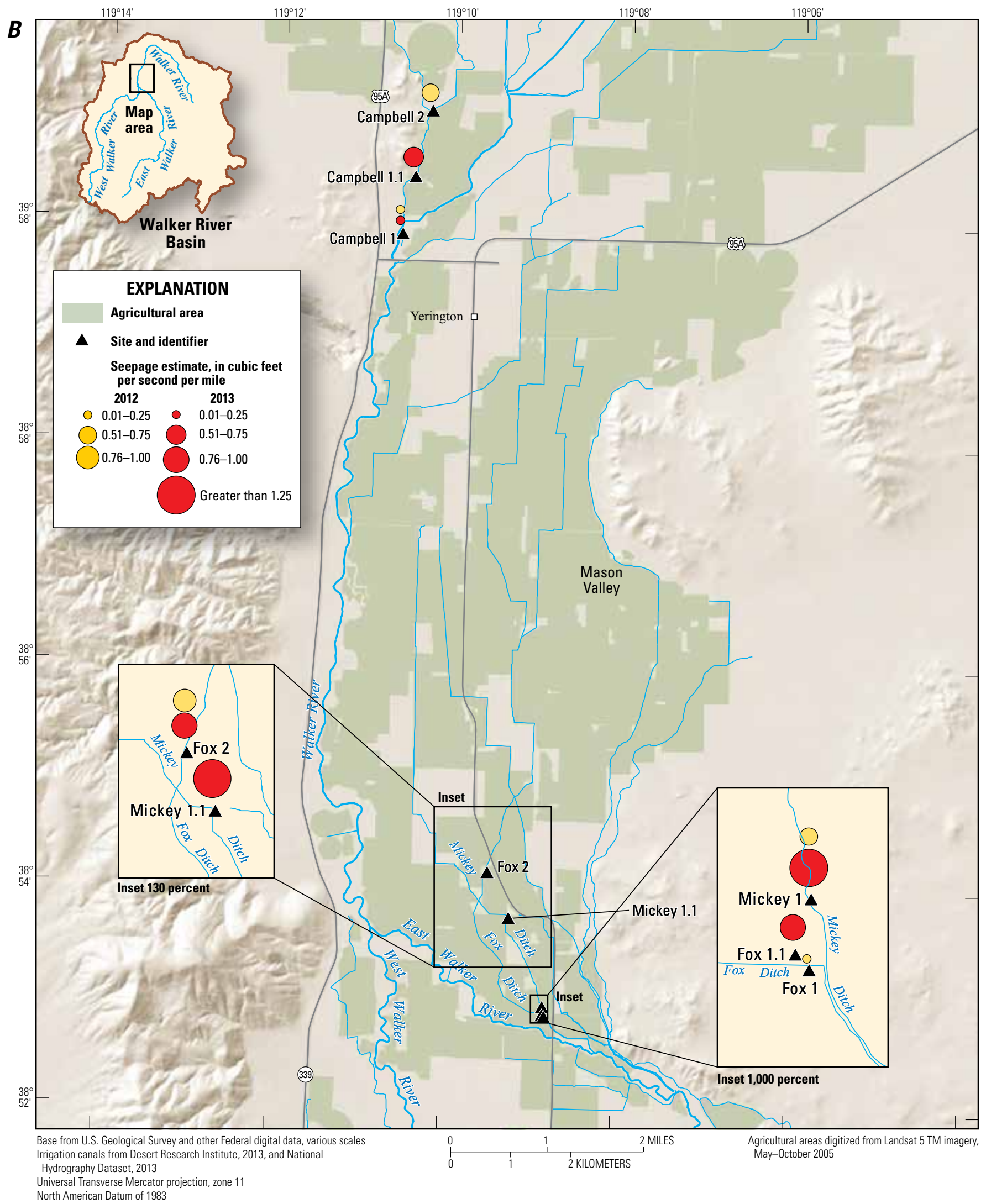

Figure 9 Estimated rates of seepage from selected irrigation canals in $A$, Smith Valley, $B$, Mason Valley, and $C$, Walker Lake Valley, Nevada. The following sites were instrumented in 2013 for seepage estimation: Smith Valley transect sites Saroni 1.1, 1.2, 1.3, 2.1, 2.2; Mason Valley transect sites Mickey 1.1, Fox 1.1, and Campbell 1.1; and all of the Walker Lake Valley sites.—Continued 


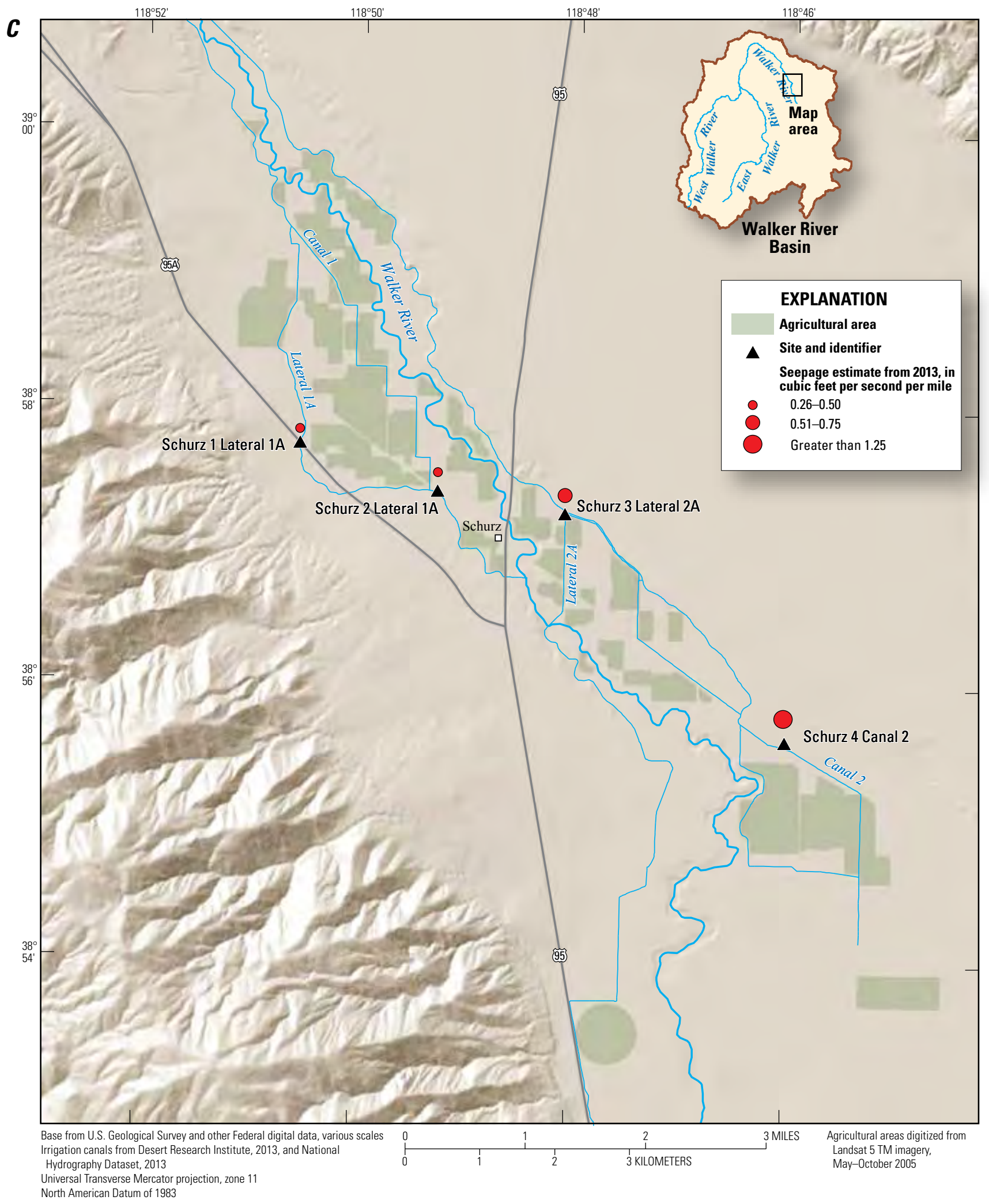

Figure 9 Estimated rates of seepage from selected irrigation canals in $A$, Smith Valley, B, Mason Valley, and $C$, Walker Lake Valley, Nevada. The following sites were instrumented in 2013 for seepage estimation: Smith Valley transect sites Saroni 1.1, 1.2, 1.3, 2.1, 2.2; Mason Valley transect sites Mickey 1.1, Fox 1.1, and Campbell 1.1; and all of the Walker Lake Valley sites.-Continued 
a lateral from the main Saroni canal. The high rate of seepage at Saroni 4 may be due to the settling of fine sediments upgradient of the site where a gate structure that diverts water into this segment of the canal is located. During the equipment installation and soil core sampling effort, very little accumulation of fine sediments transported by the surface water was present at this site (fig. 10). For comparison, rates reported by Loeltz and Eakin (1953) for the upper section of the Saroni canal near transect sites Saroni 1 and 2 was $1.25 \mathrm{ft}^{3} / \mathrm{s}-\mathrm{mi}$ during an inflow-outflow measurement of $47 \mathrm{ft}^{3} / \mathrm{s}$. Flow rates in the canal were not measured during this study; however, the canal flow rate, methodology, and associated uncertainty may explain in part these differences in seepage rates.

The total loss per year is directly related to the frequency and duration of canal flow, and from 2012 to 2013 the number of days the Saroni canal had water decreased by an average of 57 to 124 (tables 5 and 6). For comparison, in an average water year, the number of days of irrigation typically reported is 208. In 2013, the seepage rate from the Plymouth canal was similar to 2012 (table 6); however, the volumetric loss was reduced by 50 percent due to the 50 -percent reduction in the number of canal flow days. The seepage rates on the Plymouth canal in 2012 were among the lowest, ranging from 0.01 to $0.2 \mathrm{ft} / \mathrm{d}\left(0.01\right.$ to $\left.0.1 \mathrm{ft}^{3} / \mathrm{s}-\mathrm{mi}\right)$.

The calibrated model for the Saroni canal was able to reasonably match the subsurface temperatures measured in 2012; however, the simulations for the 2013 season did not produce satisfactory results. The sediment diurnal temperature data were much more dampened compared to simulated temperatures (not shown). The dampened temperature cycles indicate reduced leakage rates through canal-bed sediments. A reduction in leakage may have been caused by fine sediments with low hydraulic conductivity deposited near the sediment-water interface. During site visits between diversion periods, evidence of localized deposition of fine sediment on the canal bed was observed at Saroni 1 (fig. 9A). Deposition of fine sediment over sensor arrays likely would dampen diurnal sediment temperature cycles and potentially could reduce canal leakage. Following recalibration with 2013 temperature data, the estimated seepage rate was reduced by 90 percent at Saroni 1 due to localized siltation, resulting in a loss rate of $0.05 \mathrm{ft} / \mathrm{d}\left(0.05 \mathrm{ft}^{3} / \mathrm{s}-\mathrm{mi}\right)$. Sediment deposition may be localized such that it may not affect the leakage rates of an entire reach as indicated by the negligible reduction in seepage at Saroni 2 from $0.04 \mathrm{ft} / \mathrm{d}$ in 2012 to $0.03 \mathrm{ft} / \mathrm{d}$ in 2013. The rates of seepage increased by a factor of 2 at Saroni 3 between 2012 and 2013, from 0.02 to $0.04 \mathrm{ft} / \mathrm{d}$, respectively. The change in rates are minor compared to other sites on the Saroni canal ( 0.03 to $0.5 \mathrm{ft} / \mathrm{d}$ ), and the difference in seepage may be due to uncertainty in recalibration given the differences in estimated thermal and hydraulic conductivity for canal sediments in 2012 and 2013 (appendix 5). Uncertainty in thermal parameters can cause greater errors in seepage estimates where heat transport is dominated by conduction such as those in lower hydraulic conductivity soils (Constantz and others, 2003).

At Saroni 4 the rates increased by a factor of 1.5 from 1.6 to $2.5 \mathrm{ft} / \mathrm{d}$ between 2012 and 2013. Although rates increased in 2013, the volumetric loss was 57-percent lower due to the reduction in water use during 2013. At this site, the difference in canal usage between 2012 and 2013 was 124 days, which further translates to a reduction of $86 \mathrm{acre}-\mathrm{ft} / \mathrm{mi} / \mathrm{ag}$ yr. The increase in loss rates at Saroni 4 also may be due to the greater variability in canal flow and the predominant soil moisture conditions following prolonged periods of no flow in the canals. At Saroni 4 in 2012, the flow in the canal was nearly continuous, and in 2013 , flow was very intermittent (appendix 1A, figs. 1A-62B and 65B). The unsaturated properties, namely the hydraulic conductivity, are higher at low soil moisture contents than at saturation. Therefore, the simulated seepage rates are sensitive to the variable moisture conditions in canal sediments, especially at early stages of canal flow following prolonged periods of dry conditions.

\section{Mason Valley (Fox, Mickey, and Campbell Ditches)}

The Fox and Mickey ditches are located along the East Walker River near the northern portion of the Wassuk Range (fig. 2B). Downgradient from the confluence of East and West Walker River near the city of Yerington and just north of the 95A bridge is the diversion structure for the Campbell ditch. The extent of connectivity between canals in Mason Valley and the alluvial aquifer may depend on location, the depth of canal incision, and timing of groundwater-level declines due to pumping. For example, the base altitude of the Mickey ditch is $15-20 \mathrm{ft}$ below the adjacent land surface and was hydraulically connected. In contrast, the Fox ditch is $2-6 \mathrm{ft}$ below the adjacent area and was hydraulically disconnected. Groundwater pumping results in a lowering of the water table despite increased infiltration and mounding due to seepage and agricultural use from nearby canals and fields. The transect locations and the estimated seepage rates are shown in figure $9 B$. The simulated and observed temperatures for the Mason Valley canal sites for the 2012 and 2013 irrigation seasons are shown in appendix 2A to 2C. During the 2013 irrigation season, additional transect sites were added to the Fox (Fox 1.1), Mickey (Mickey 1.1), and Campbell (Campbell 1.1) ditches.

Flow in the Fox ditch was very dynamic and sediment deposition and scour around the temperature probes was persistent, thus potentially contributing to uncertainty in seepage estimation. During extended periods of canal flow, 0.1 to $0.2 \mathrm{~m}$ of sediment would periodically erode from the temperature probes located in the canal at the Fox 1 transect. This was evident by physical observation and by anomalies in the observed temperature data at multiple depth observations such as those at 0 to $0.20-\mathrm{m}$ depths would be similar (no thermal gradient or lag). The first 1,000 hours of irrigation in 2012 were used for model calibration during a time that sediment movement around the temperature probes was not an issue. The residual errors increased in 2012 (simulation period 500 to 2,500 hours) as changes in the amplitudes of the observed temperatures at 0.10 - and $0.20-\mathrm{m}$ depths occurred due to 

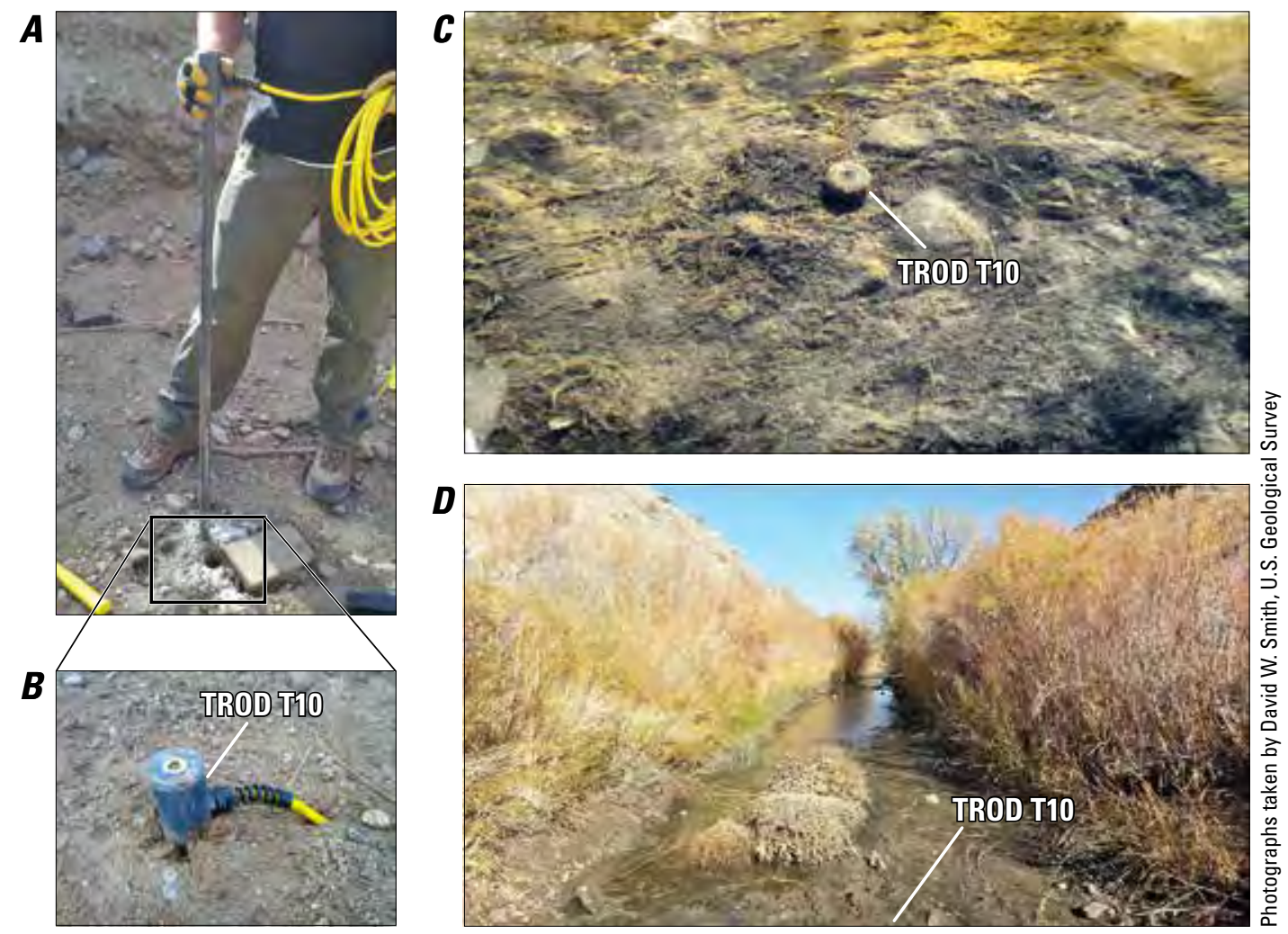

Figure 10. SARONI CANAL 1 site TROD T10 A, during site installation on 3/12/2012, $B$, showing closeup of TROD T10 head about 0.40 foot above canal bottom, $C$, during canal flow on 2/13/2013 (TROD head about 0.10 foot above canal bottom), and $D$, approximate location of buried TROD T10 on 1/30/2014 (TROD head about 0.10 foot below canal bottom).

scour (appendix 2A, fig. 2A-6A). Assuming constant model parameters from calibration, the estimated seepage rate for the Fox ditch 1 during 2012 was $0.3 \mathrm{ft} / \mathrm{d}(0.2 \mathrm{ft} / \mathrm{s}-\mathrm{mi})$. In 2013 , equipment from Fox 1 was moved $50 \mathrm{ft}$ down the canal, away from the diversion gate on the Mickey ditch. The seepage estimates at the new location of Fox 1.1 were $1.7 \mathrm{ft} / \mathrm{d}$, an estimate similar to Fox 2 (1.6 ft/d; table 6). Prior to the 2013 irrigation season, a concrete structure was constructed to control flow and sediment into the Fox ditch that helped alleviate sediment transport issues at Fox 1.1.

In 2012, the estimated seepage from Mickey ditch 1 was $1.6 \mathrm{ft} / \mathrm{d}\left(0.6 \mathrm{ft}^{3} / \mathrm{s}-\mathrm{mi}\right)$ (table 5); the rates increased in 2013 to $3.2 \mathrm{ft} / \mathrm{d}\left(1.3 \mathrm{ft}^{3} / \mathrm{s}-\mathrm{mi}\right)$. During early spring of 2012, the Mickey ditch 1 transect was hydraulically connected to the alluvial aquifer, and following extensive lowering of the water table in May 2012, the canal was disconnected continuously through the 2013 agricultural season (fig. 11A). The estimated seepage shown in figure $2 \mathrm{~B}-7 \mathrm{~B}$ of appendix $2 \mathrm{~B}$ for the Mickey ditch shows that during the period when the canal was hydraulically connected, the seepage rates were an average of $0.82 \mathrm{ft} / \mathrm{d}$ $(0.25$ meter per day $(\mathrm{m} / \mathrm{d}))$ during March to May (simulation period $0-1,500$ hours). The declines in the aquifer in July 2012 resulted in greater seepage losses as the canal was no longer hydraulically connected. During the period from July to October 2012 (simulation period 2,500-4,500 hours), the seepage rates increased to an average of $3.1 \mathrm{ft} / \mathrm{d}(0.94 \mathrm{~m} / \mathrm{d})$. From July to October and in 2013, there were periods when the canal was not flowing and the aquifer declined more rapidly. The seepage rates increased abruptly to as high as $9.5 \mathrm{ft} / \mathrm{d}(2.9 \mathrm{~m} / \mathrm{d})$ during the initial periods of canal flow. The highest rates of seepage were estimated at Mickey $1.1\left(3.3 \mathrm{ft} / \mathrm{d}\right.$ or $\left.1.3 \mathrm{ft}^{3} / \mathrm{s}-\mathrm{mi}\right)$ and were comparable to Mickey $1\left(3.2 \mathrm{ft} / \mathrm{d}\right.$ or $\left.1.3 \mathrm{ft}^{3} / \mathrm{s}-\mathrm{mi}\right)$ (table 6).

On the Campbell 1 transect, the extent of hydraulic connectivity between the canal and the shallow aquifer varied throughout 2012 and 2013 (fig. 11B). The head in bank piezometer BP1 decreased $1.15 \mathrm{~m}$ from April to October 2012 as a consequence of water-table declines due to groundwater pumping. Lowering the water table resulted in an increase in seepage rates from 0.05 to $0.1 \mathrm{~m} / \mathrm{d}$ at the end of the year (appendix 2C, fig. 2C-6C). During the period when the water table drops below the canal altitude, the aquifer responds to rapid increases in canal stage as shown by abrupt changes in head in the well. The aquifer recovers by April 2013 and then declines $1.6 \mathrm{~m}$ between May and October 2013 (fig. 11B). The effect of rises in the water table reduces the seepage rates estimated in the model. However, as shown in the Mickey ditch 1 (fig. 11A), and conceptualized in figure 6, when the water table declines to an altitude where the canal is no longer affected by the aquifer head, the seepage rates increase and following prolonged periods of no flow, even greater rates occur during the initial periods of canal flow. During the early irrigation season of March 2012 when the canal was hydraulically connected to the aquifer, the seepage rates were approximately 


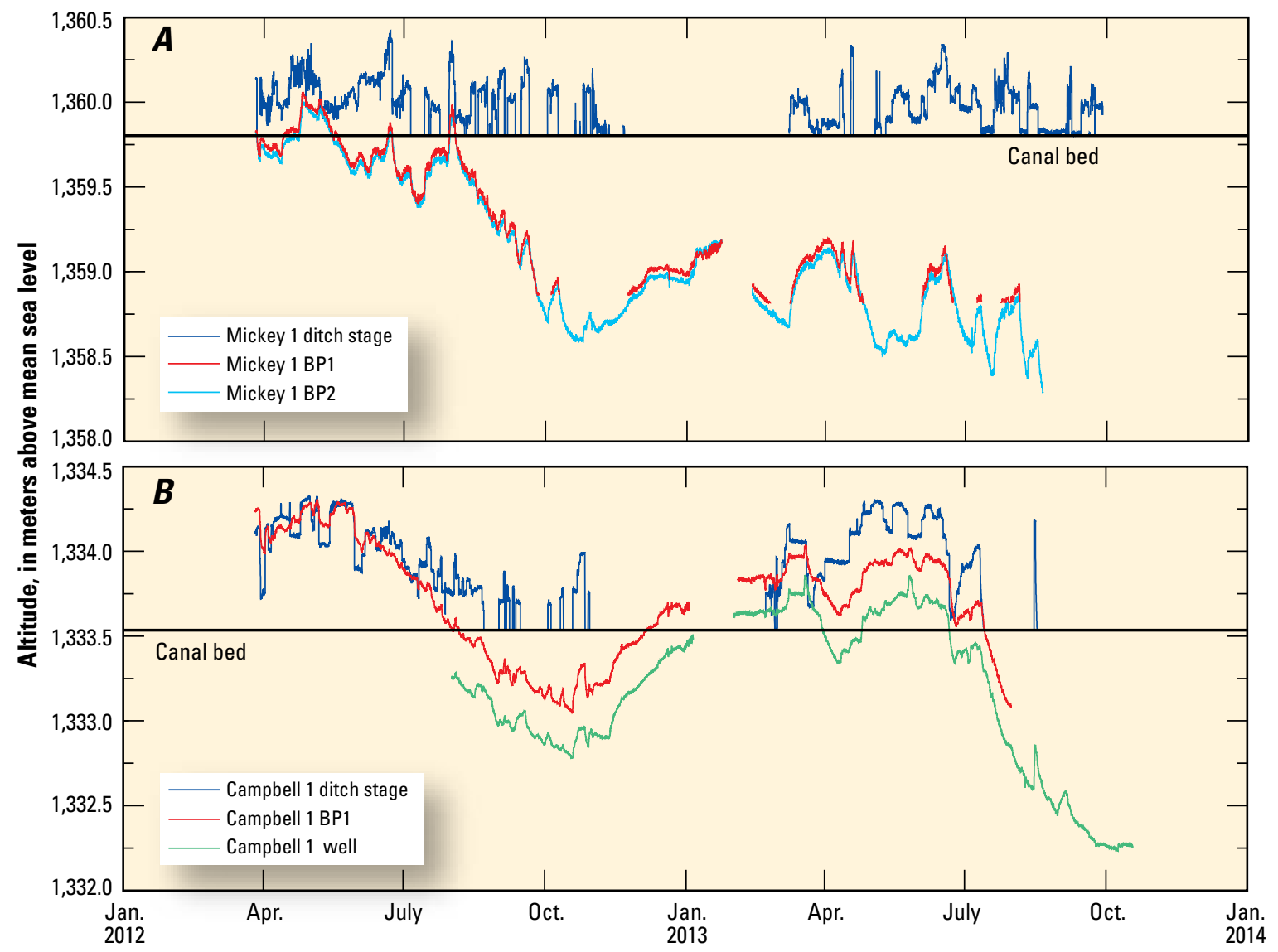

Figure 11. Measured stage and piezometric head in 2012-13 at site 1 on the $A$, Mickey ditch, and $B$, Campbell ditch. At the Mickey site, the water table dropped below the bottom of piezometer BP1 intermittently in both 2012 and 2013.

$0.25 \mathrm{~m} / \mathrm{d}$ (appendix 2B, fig. $2 \mathrm{~B}-7 \mathrm{~B}$, simulation period 0 to 500 hours) at approximately $0.25 \mathrm{~m}$ of stage. Following declines in the water table and a prolonged period of no flow, the canal became hydraulically disconnected by the end of the simulation period in August 2013 (fig. 11A), and the estimated seepage rate was $1.2 \mathrm{~m} / \mathrm{d}$ for an equivalent stage (appendix $2 \mathrm{~B}$, fig. $2 \mathrm{~B}-8 B$, simulation period 3,700 to 3,900 hours). This corresponds to a 380-percent increase (a factor of 5) in seepage due to loss of hydraulic connectivity between the water in the canal and the water table.

\section{Walker Lake Valley (Schurz Canals 1A, 2A, and Canal 2)}

The network of canals on the WRPIR is located just downgradient of the Weber Reservoir at a diversion structure known as Little Dam in the rural community of Schurz (fig. 2C). The canal transects investigated were hydraulically disconnected from the aquifer, and seepage rates were not affected by a high water table or regional groundwater pumping. The transect locations and the estimated seepage rates are shown in figure $9 C$. The simulated and observed temperatures for the Walker Lake Valley Schurz canal sites (referred to as Schurz) during the 2013 irrigation season are shown in appendix 3A to 3C. Data collected on the Schurz sites began at the start of the 2013 irrigation season.
Diversions into Lateral Canals 1A and 2A during the 2013 irrigation season were very intermittent. The average seepage loss from the Schurz 1 Lateral 1 A canal was $0.7 \mathrm{ft} / \mathrm{d}$ $\left(0.4 \mathrm{ft}^{3} / \mathrm{s}-\mathrm{mi}\right)$ (table 6$)$. The highest rates of seepage were estimated to be $0.9 \mathrm{ft} / \mathrm{d}\left(0.7 \mathrm{ft}^{3} / \mathrm{s}-\mathrm{mi}\right)$ at the Schurz 3 Lateral $2 \mathrm{~A}$ canal. The duration of continuous flow has significant impact on the rate of seepage in the canals, and in disconnected systems, canal stage can be used as a predictor for seepage rates as head in the canal primarily drives seepage loss. However, the relation between stage and seepage can be non-linear if persistent periods of no flow exist and the canal loses soil moisture through gravity drainage and evaporation. For lateral canals in the Schurz study area, this is often the case, as flows are diverted from the main canal for a few days, then dry for several weeks. The seepage rates in figure 12 show two contrasting sites where stage-seepage relations are non-linear and linear. At Schurz 3 Lateral $2 \mathrm{~A}$, there were very frequent periods of no flow (appendix 3B, fig. 3B-6B). During 2013, 171 days of simulation were used to capture periods of flow that summed up to 26 total days of flow (table 6). At Schurz 4 Canal 2, there were slightly more consistent days of canal flow, and the seepage losses increased linearly with canal stage (fig. 12B). Identifying the frequency and duration of flow in canals and the effect of early seepage losses is critically important when estimating volumetric losses. 

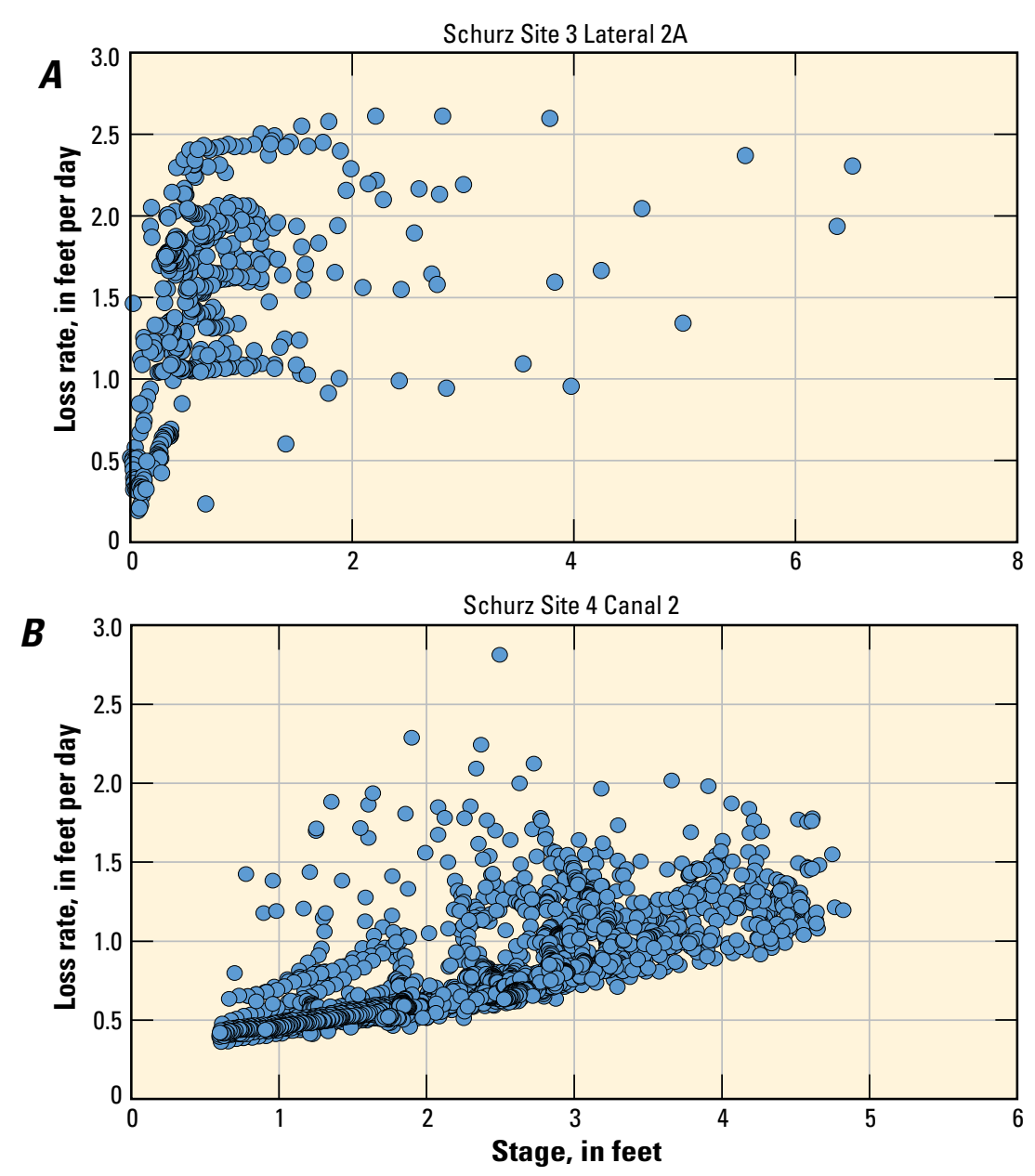

Figure 12. Canal seepage loss rates in relation to stage in the Schurz study area for $A$, a lateral canal with intermittent periods of no flow, and $B$, a main canal with consistent flow. The seepage rates in the lateral canal are greatly affected by initial periods of canal flow followed by prolonged periods of no flow.

\section{Seepage Rate Comparisons}

The seepage estimates for each transect represent a detailed monitoring and modeling effort to determine the temporal and spatial variability at one location. However, the seepage loss along each transect needs to be scaled up to the entire length of the canal to be more meaningful to water managers. Diversion data were not available for irrigation seasons 2011-12 so comparisons to seepage estimates by Carroll and others (2010) could not be made. In this report, the annual loss rate was determined by calculating the average seepage loss by the canal length during the period of canal flow for the 2012 and 2013 irrigation seasons (table 7). For the Smith Valley canal sites, the nearly 50 -percent reductions in volumetric loss rates between 2012 and 2013 were associated with less than average diversions into canals from the Walker River and reductions in infiltration rates following routine canal maintenance. The total seepage losses from the Saroni canal for the 2012 and 2013 irrigation seasons were estimated to be 1,100 and 590 acre-ft, respectively. Lower rates of seepage from the Plymouth canal for the 2012 and 2013 irrigation seasons were estimated to be 210 and 130 acre-ft, respectively. For the Mason Valley canal sites, the rate increases between 2012 and 2013 are likely due to the increase in canal seepage loss resulting from lowering of the water table in hydraulically connected canals. The seepage loss for the Fox ditch did not exhibit significant year to year variability. The annual seepage losses estimated for 2012 and 2013 in the Fox ditch were 2,100 and 2,200 acre-ft, respectively. For the Mickey ditch, the seepage loss was 1.5 times the rate estimated in 2012 despite having 45 days less canal flow. Similarly, the Campbell ditch seepage loss increased slightly from 660 to 700 acre-ft, a factor of 1.1, with 49 days less flow. The 2013 loss rates estimated for the WRPIR canals were variable due to canal flow duration and length of the canal. The annual estimated seepage loss in Walker Lake Valley ranged between 50 and 725 acre-ft among the transect sites. The loss rates estimated for Schurz Canal 2 were relatively high compared to other sites, such as the Campbell ditch, given that the total length of unlined canal is only $3 \mathrm{mi}$. 
Seepage rates estimated for the Walker River Basin irrigation canals have both spatial and temporal uncertainty that were indirectly evaluated for this study. The uncertainty of model simulations was not directly evaluated because of the computational time needed to address parameter uncertainty at 22 locations. Uncertainty was considered in the experimental design by the collection of data at multiple transects along the canals and during multiple irrigation seasons to address aspects of the spatial and temporal variability of seepage losses. Spatial uncertainty arises primarily from the variability of soil hydraulic properties along the canals, namely hydraulic conductivity, and physical controls such as gate structures that control sediment. The seepage rates estimated at each transect along the canal were applied along a 1-mi segment of canal assuming similar soil hydraulic properties, wetted perimeter, and hydraulic connectivity.

To address the spatial uncertainty in soil hydraulic properties, a number of additional monitoring sites were added in 2013 based on permission granted by the WRID, to evaluate the spatial heterogeneity of seepage rates along the canals, such as those in the Saroni canal, and Mickey and Campbell ditches. The seepage rates among the studied transects provide insight into the range of uncertainty along the canals. For example, in 2013, the large range in seepage rates along the Saroni canal (0.03-2.5 ft/d) (table 6) was attributed to physical controls on surface-water flow and siltation caused by the gate structure upgradient of Saroni site 4. Accounting for the wetted perimeter of each transect, the estimated seepage along Saroni transect sites 1-3 was consistently low, between 0.03 and $0.5 \mathrm{ft}^{3} / \mathrm{s}-\mathrm{mi}$. The higher seepage rates at Saroni site $4\left(0.68 \mathrm{ft}^{3} / \mathrm{s}-\mathrm{mi}\right)$ were due to the settling of fine sediments behind a gate structure upgradient that reduced sediment clogging along this lateral canal site.

The temporal uncertainty in seepage loss is primarily caused by sediment transport (scour and siltation) and differences in interannual diversions into each canal. For example, the differences in seepage rates from the Saroni canal between 2012 and 2013 were largely attributed to siltation following canal maintenance. Differences in seepage rates for the Mason Valley canals between 2012 and 2013 were largely due to the influence of water-table declines on seepage loss. Annual seepage loss was also variable due to the decrease in diversions and number of canal flow days.

\section{Summary and Conclusions}

Since the 1860s, water diverted from the Walker River has been an important resource for agriculture. The reduced flows into Walker Lake have resulted in lake-level declines, loss of storage, and degraded water quality, threatening the freshwater ecosystems. The efforts to refine water budgets within the Walker River Basin and purchase water rights to restore the lake levels and improve water quality have contributed to new investigations to evaluate the effects of changing water use at the farm-scale and efficacy of management options on increasing flows into Walker Lake. This study is part of the efforts by the U.S. Geological Survey in collaboration with the Bureau of Reclamation to refine recharge estimates for water budgets and to provide baseline data to evaluate changing water use. The data collected can also be useful for managers of the Walker River Irrigation District (WRID) and the Walker River Paiute Indian Reservation (WRPIR) to obtain seepage rates related to the temporal variability, canal flow duration, groundwater pumping, and frequency of canal use. This report presents an extensive data and model effort used to characterize seepage losses in selected canals in the Walker River Basin. The number and location of study sites were determined based on permission of farmers, the WRID, and the WRPIR. The study was conducted during the 2012 and 2013 irrigation seasons in both hydraulically connected and disconnected canals. Multidepth observations of temperature using heat as a tracer were incorporated in a numerical model to quantify seepage rates as a function of varying stage and groundwater levels.

Hydraulic and thermal properties of canal sediments were estimated using an inverse modeling approach, assuming a multi-layered conceptualization of soil textures. Comparisons between simulated and measured temperatures and groundwater-level measurements were used to evaluate the VS2DH models during a calibration period and then used to predict seepage rates for both irrigation seasons. Deviations in model performance helped determine changes in seepage rates due to canal siltation where reduction in permeability of canal sediments occurred following routine canal maintenance. A newly designed temperature probe used in this study helped provide a continuous record of subsurface temperatures that were useful in monitoring diel temperature variations as well as long-term seasonal changes in temperature caused by weather conditions. The ability to monitor the duration and frequency of flow in the canals help to refine the estimates of total canal loss as year to year variability of available water influences seepage rates. The use of heat as a tracer in this study demonstrates the value of long-term monitoring and modeling seepage variations that can improve an understanding of linkages and feedbacks between groundwater and surface-water systems.

The connectivity of groundwater and surface-water systems is critical for understanding water resources in the Walker River Basin. A significant source of groundwater recharge in parts of the Walker River Basin is from irrigation canal leakage; therefore, changes in water availability have direct implications on recharge. Less surface water available for irrigation will increase the reliance on pumping groundwater, thus impacting the conveyance and delivery of water in canals that are hydraulically connected. Lowering of the water table in these systems causes the canals to become hydraulically disconnected from the aquifer, effectively increasing seepage rates and reducing delivery efficiency. 


\section{References Cited}

Alam, M.M., and Bhutta, M.N., 2004, Comparative evaluation of canal seepage investigation techniques: Agricultural Water Management, v. 66, p. 65-76.

Allander, K.K., Niswonger, R.N., and Jeton, A.E., 2014, Simulation of the lower Walker River Basin hydrologic system, west-central Nevada, using PRMS and MODFLOW models: U.S. Geological Survey Scientific Investigations Report 2014-5190, 93 p., http://dx.doi.org/10.3133/sir20145190.

Allander, K.K., Smith, J.L., and Johnson, M.J., 2009, Evapotranspiration from the lower Walker River Basin, west-central Nevada, water years 2005-07: U.S. Geological Survey Scientific Investigations Report 2009-5079, 62 p.

Andersen M.P., 2006, Heat as a ground water tracer: Ground Water, v. 43, no. 6, p. 951-968.

Brunner, P., Cook, P.G., and Simmons C.T., 2009, Hydrogeologic controls on disconnection between surface water and groundwater: Water Resources Research, v. 45, W01422, http://dx.doi.org/10.1029/2008WR006953.

Carroll, R.W., Pohll, G.M., McGraw, D.S., Garner, C., Knust, A.M., Boyle, D., Minor, T., Bassett, S., and Pohlmann, K.F., 2010, Mason Valley groundwater model—Linking surface and groundwater processes in the Walker River basin, Nevada: Journal of American Water Resources Association, v. 46 , no. 3 , p. $554-573$, http://dx.doi.org/10.1111/j.1752-1688.2010.00434.x.

Carsel, R.F., and Parrish, R.S., 1988, Developing joint probability distributions of soil water retention characteristics: Water Resources Research, v. 24, no. 5, p. 755-769, http://dx.doi.org/10.1029/WR024i005p00755.

Constantz, J.E., Niswonger, R.G., and Stewart, A.E., 2008, Analysis of temperature gradients to determine stream exchanges with ground water, in Rosenberry, D.O., and LaBaugh, J.W., eds., Field techniques for estimating water fluxes between surface water and ground water: U.S. Geological Survey Techniques and Methods 4-D2, p. 115-128.

Constantz, J., Tyler, S.W., and Kwicklis, E., 2003, Temperature-profile methods for estimating percolation rates in arid environments: Vadose Zone Journal, v. 2, p. 12-24.

Doherty, J., 2007, PEST-Model-Independent Parameter Estimation and Uncertainty Analysis: Watermark Numerical Computing, Brisbane, Australia, accessed May 2012, at http://pesthomepage.org/Home.php.

Everett, D.E., and Rush, F.E., 1967, A brief appraisal of the water resources of the Walker Lake area, Mineral, Lyon, and Churchill Counties, Nevada: Nevada Department of Conservation and Natural Resources, Water ResourcesReconnaissance Series Report 40, 44 p.
Halford, K., Garcia, C.A., Fenelon, J., and Mirus, B., 2012, Advanced methods for modeling water-levels and estimating drawdowns with SeriesSEE, an Excel add-in: U.S. Geological Survey Techniques and Methods 4-F4, 28 p.

Healy, R.W., and Ronan, A.D., 1996, Documentation of computer program VS2DH for simulation of energy transport in variably saturated porous media; modification of the U.S. Geological Survey's computer program VS2DT: U.S. Geological Survey Water-Resources Investigations Report 96-4230, 36 p., available at http://pubs.er.usgs.gov/pubs/ wri/wri964230.

Hobza, C.M., and Andersen, M.J., 2010, Quantifying canal leakage rates using a mass-balance approach and heatbased hydraulic conductivity estimates in selected irrigation canals, western Nebraska, 2007 through 2009: U.S. Geological Survey Scientific Investigations Report 2010-5226, $45 \mathrm{p}$.

Hsieh, P.A., Wingle, W.L., and Healy, R.W., 2000, VS2DIA graphical software package for simulating fluid flow and solute or energy transport in variably saturated porous media: U.S. Geological Survey Water-Resources Investigations Report 99-4130, 16 p.

Leoltz, O.J., and Eakin, T.E., 1953, Geology and water resources of Smith Valley, Lyon and Douglas Counties, Nevada: U.S. Geological Survey Water-Supply Paper 1228, $94 \mathrm{p}$.

Lopes, T.J., 2005, Science to sustain terminal lakes-The Walker River Basin study: U.S. Geological Survey Fact Sheet 2005-3124, 2 p.

Lopes, T.J., and Allander, K.K., 2009a, Hydrologic setting and conceptual hydrologic model of the Walker River basin, California and Nevada: U.S. Geological Survey Scientific Investigations Report 2009-5155, 84 p., available at http://pubs.usgs.gov/sir/2009/5155.

Lopes, T.J., and Allander, K.K., 2009b, Water budgets of the Walker River basin and Walker Lake, California and Nevada: U.S. Geological Survey Scientific Investigations Report 2009-5157, 44 p., available at http://pubs.usgs.gov/sir/2009/5157.

Lopes, T.J., Buto, S.G., Smith, J.L., and Welborn, T.L., 2006, Water-table levels and gradients, Nevada, 1947-2004: U.S. Geological Survey Scientific Investigations Report 20065100,35 p., 3 pls.

Lopes, T.J., and Medina, R.L., 2007, Precipitation zones of west-central Nevada: Journal of Nevada Water Resources Association, v. 4, no. 2, p. 1-19. 
Lopes, T.J., and Smith, J.L., 2007, Bathymetry of Walker Lake, west-central Nevada: U.S. Geological Survey Scientific Investigations Report 2007-5012, 26 p., available at http://pubs.usgs.gov/sir/2007/5012/.

Martin, C.H., and Gates, T.K., 2014, Uncertainty of canal seepage losses estimated using flowing water balance with acoustic Doppler devices: Journal of Hydrology, v. 517, p. 746-761, http://dx.doi.org/10.1016/j.jhydrol.2014.05.074.

Maurer, D.K., Lopes, T.J., Medina, R.L., and Smith, J.L., 2004, Hydrogeology and hydrologic landscape regions of Nevada: U.S. Geological Survey Scientific Investigations Report 2004-5131, 35 p., available at http://pubs.usgs.gov/sir/2004/5131/.

Mihevc, T., Pohll, G., Niswonger, R., and Stevick E., 2002, Truckee Canal seepage analysis in the Fernley/Wadsworth area, Las Vegas, Nevada: Desert Research Institute Publication No. 41176, 44 p.

Naranjo, R.C., Niswonger, R.G., Stone, M., Davis, C., and Mckay, A., 2012, The use of multiobjective calibration and regional sensitivity analysis in simulating hyporheic exchange: Water Resources Research v. 48, W01538, http://onlinelibrary.wiley.com/doi/10.1029/2011 WR011179/ full.

Naranjo, R.C., and Turcotte, R., 2015, A new temperature profiling probe for investigating groundwater-surface water interaction: Water Resources Research, v. 51, no. 9, p. 7790-7797, http://dx.doi.org/10.1002/2015WR017574.

Niswonger, R.G., and Prudic, D.E., 2003, Modeling heat as a tracer to estimate streambed seepage and hydraulic conductivity, in Constantz, J., and Stonestrom, D.A., eds., Heat as a tool for studying the movement of ground water near streams: U.S. Geological Survey Circular 1260, p. 81-89.

Rau, G.C., Andersen, M.S., McCallum, A.M., Roshan, H., and Acworth, R.I., 2014, Heat as a tracer to quantify water flow in near-surface sediments: Earth-Science Reviews, v. 129, p. $40-58$.

Rush, F.E., and Schroer, C.V., 1976, Geohydrology of Smith Valley, Nevada, with special reference to the water-use period, 1953-72: Water Resources Bulletin, no. 43, 95 p., http://images.water.nv.gov/images/publications/water\%20 resources\%20bulletins/Bulletin43.pdf.

Rydlund, P.H., Jr., and Densmore, B.K., 2012, Methods of practice and guidelines for using survey-grade global navigation satellite systems (GNSS) to establish vertical datum in the United States Geological Survey: U.S. Geological Survey Techniques and Methods, book 11, chap. D1, 102 p. with appendixes.
Schaefer, D.H., 1980, An appraisal of the water resources of the Walker River Indian Reservation, Nevada: U.S. Geological Survey Open-File Report 80-427, 65 p.

Shanafield, M., Pohll, G., and Susfalk, R., 2010, Use of heatbased vertical fluxes to approximate total flux in simple channels: Water Resources Research, v. 46, no. 3, 8 p., W03508, http://dx.doi.org/10.1029/2009WR007956.

Stonestrom, D.A., and Blasch, K.W., 2003, Determining temperature and thermal properties for heat-based studies of surface-water ground-water interactions, appendix A, in Stonestrom, D.A., and Constantz, J., eds., Heat as a tool for studying the movement of ground water near streams: U.S. Geological Survey Circular 1260, p. 73-80.

Stonestrom, D.A., and Constantz, J., eds., 2003, Heat as a tool for studying the movement of ground water near streams: U.S. Geological Survey Circular 1260, 96 p.

Taniguchi, Makoto, 1993, Evaluation of vertical groundwater fluxes and thermal properties of aquifers based on transient temperature-depth profiles: Water Resources Research, v. 29 , no. 7, p. 2021-2026, http://dx.doi.org/10.1029/93WR00541.

Tonina, D., Luce, C., and Gariglio, F., 2014, Quantifying streambed deposition and scour from stream and hyporheic water temperature time series, Water Resources Research, v. 50, p. 287-292, http://dx.doi.org/10.1002/2013WR014567. 


\section{Appendix 1A Temperature and Model Results for Saroni Canal 1, Smith Valley, Nevada}

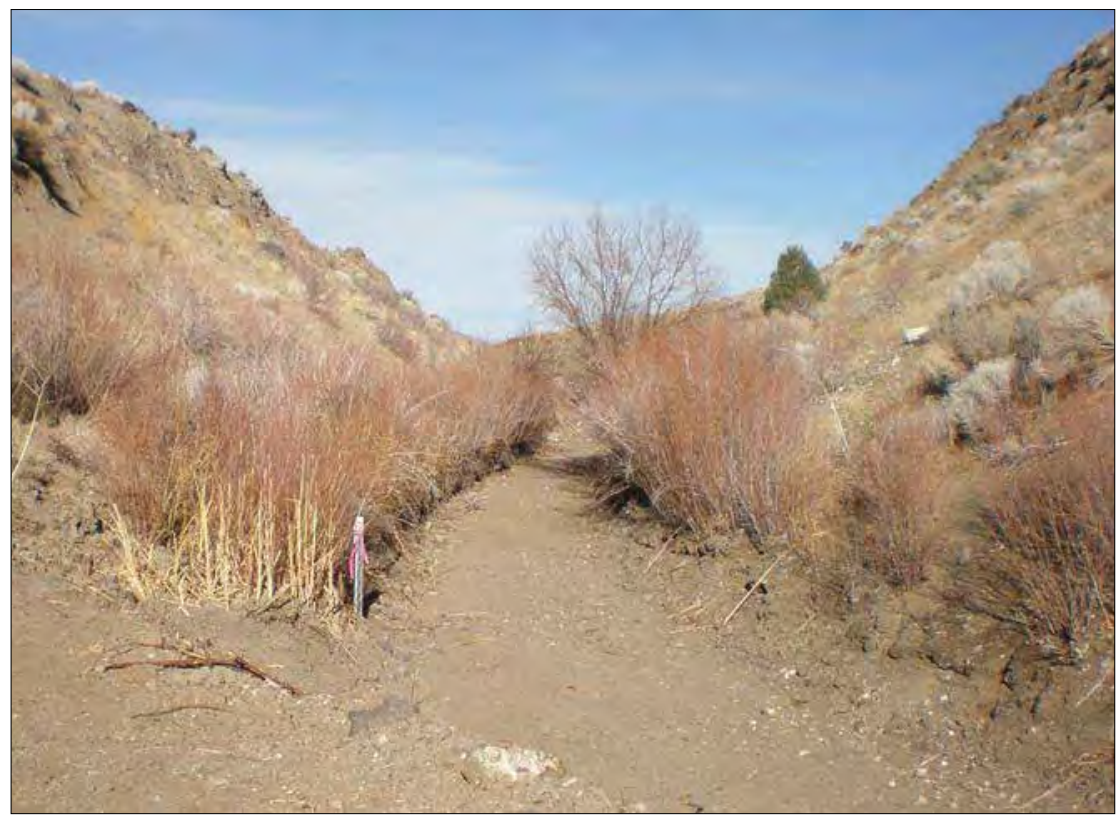

Figure 1A-1. Photograph of SARONI CANAL 1 site, Wellington, Nevada. Photograph taken by Steven Clarke, U.S. Geological Survey, looking downstream on 2/22/2012.

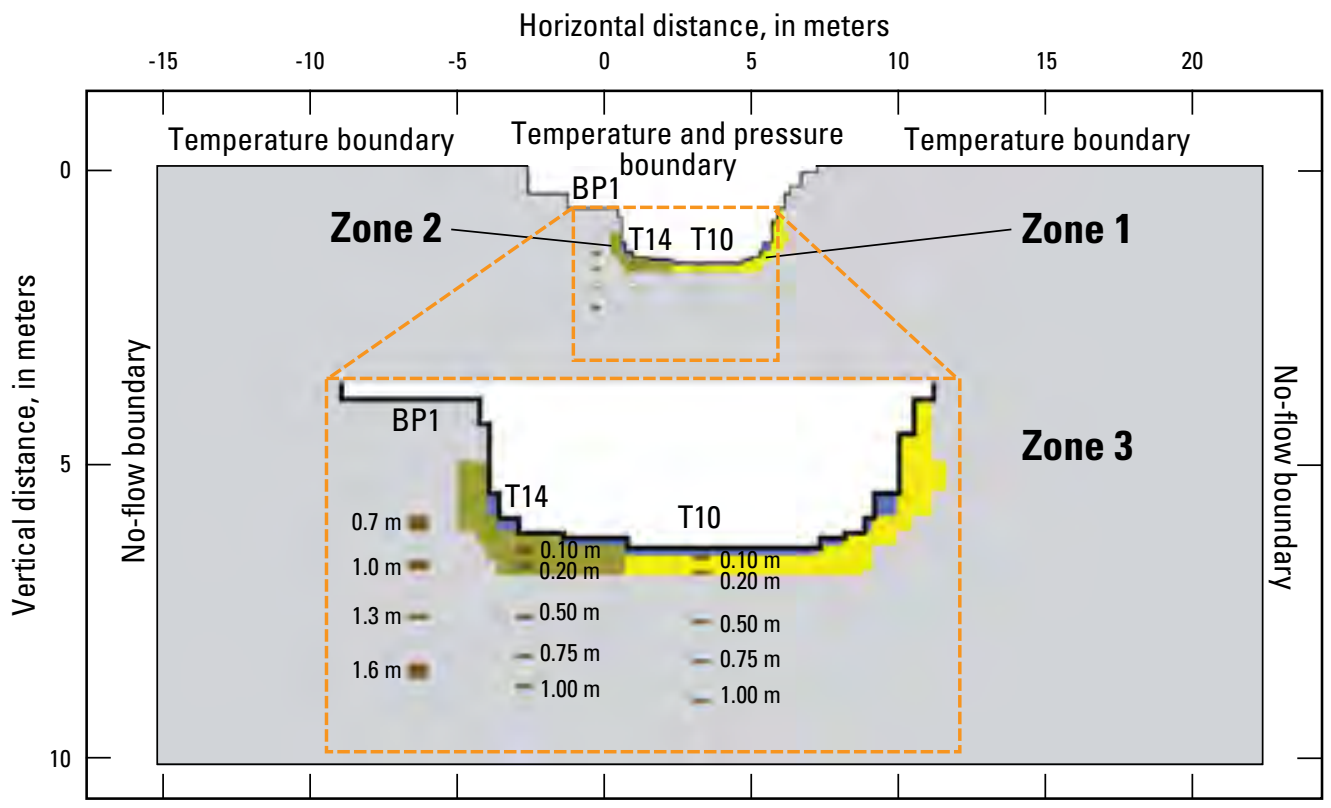

Figure 1A-2. Schematic cross section of two-dimensional VS2DH model of water and heat transport through canal-bed sediments at SARONI CANAL 1 site with soil textural zones (Zones 1-3), locations of temperature observations below ground surface within the canal (T10 and T14) and along the banks (BP1), and specified vertical and horizontal boundary conditions. 

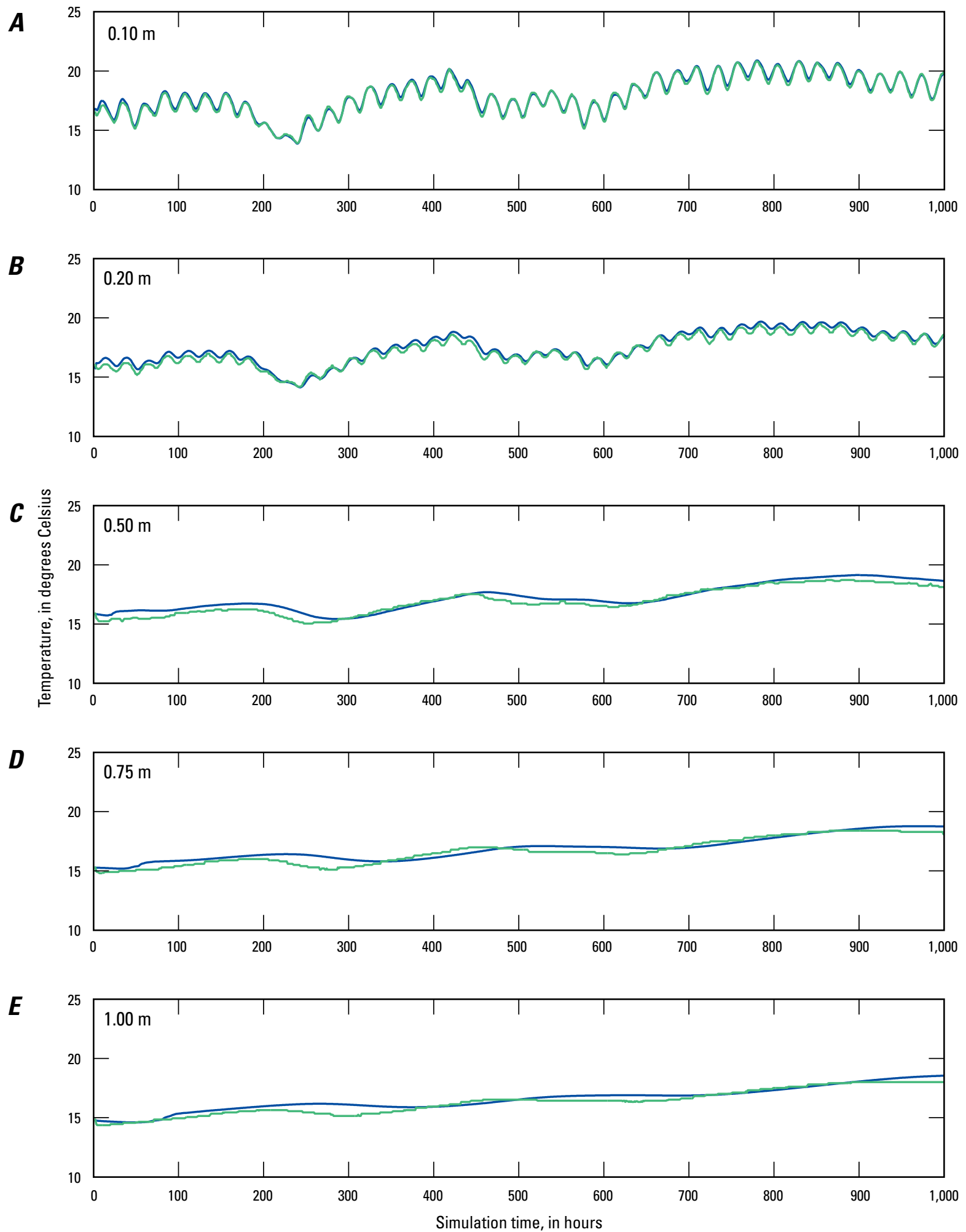

EXPLANATION

Measured

Simulated

Figure 1A-3. Measured and simulated thermographs for canal sediments for T10 at depths of $A, 0.10 \mathrm{~m}, \mathrm{~B}, 0.20 \mathrm{~m}, \mathrm{C}, 0.50 \mathrm{~m}, \mathrm{D}, 0.75 \mathrm{~m}$, and $\mathrm{E}, 1.0 \mathrm{~m}$ for the 2012 calibration period. 

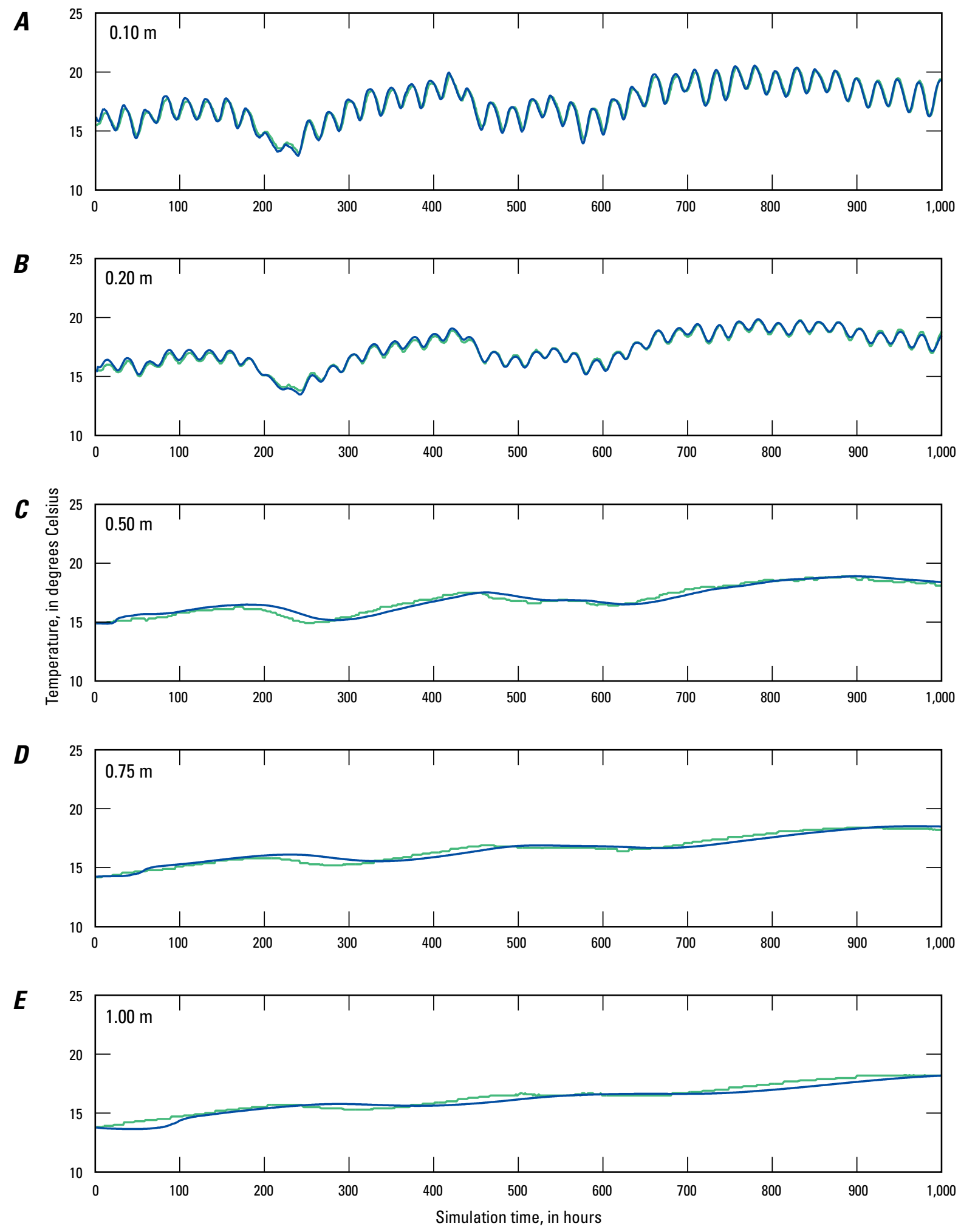

EXPLANATION

Measured

Simulated

Figure 1A-4. Measured and simulated thermographs for canal sediments for T14 at depths of A, $0.10 \mathrm{~m}, \mathrm{~B}, 0.20 \mathrm{~m}, \mathrm{C}, 0.50 \mathrm{~m}, \mathrm{D}, 0.75 \mathrm{~m}$, and $\mathrm{E}, 1.0 \mathrm{~m}$ for the 2012 calibration period. 

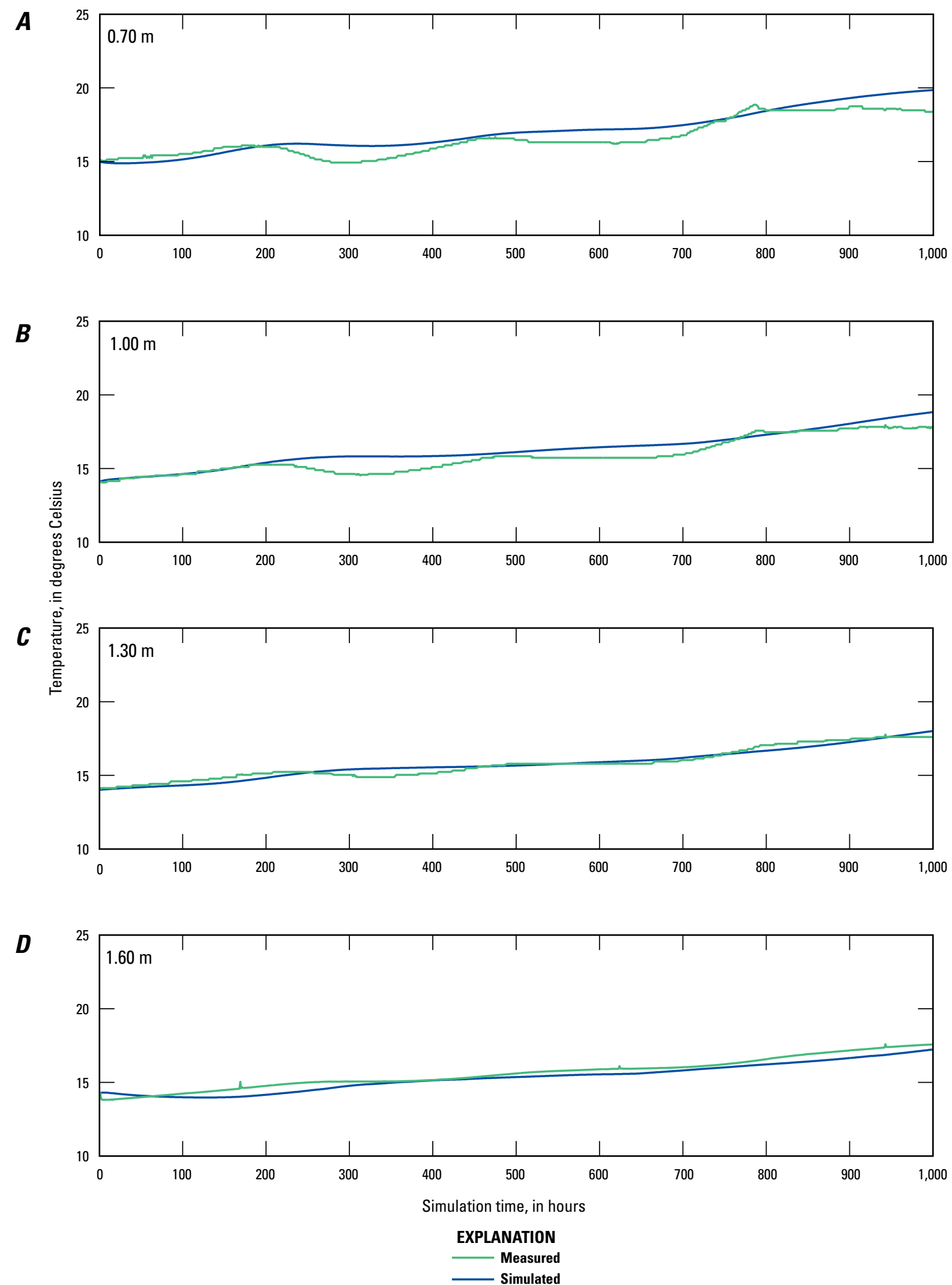

Figure 1A-5. Measured and simulated thermographs for canal sediments for Bank Piezometer 1 (BP1) at depths of $A, 0.70 \mathrm{~m}, \mathrm{~B}, 1.0 \mathrm{~m}$, C, $1.30 \mathrm{~m}$, and D, $1.60 \mathrm{~m}$ for the 2012 calibration period. 

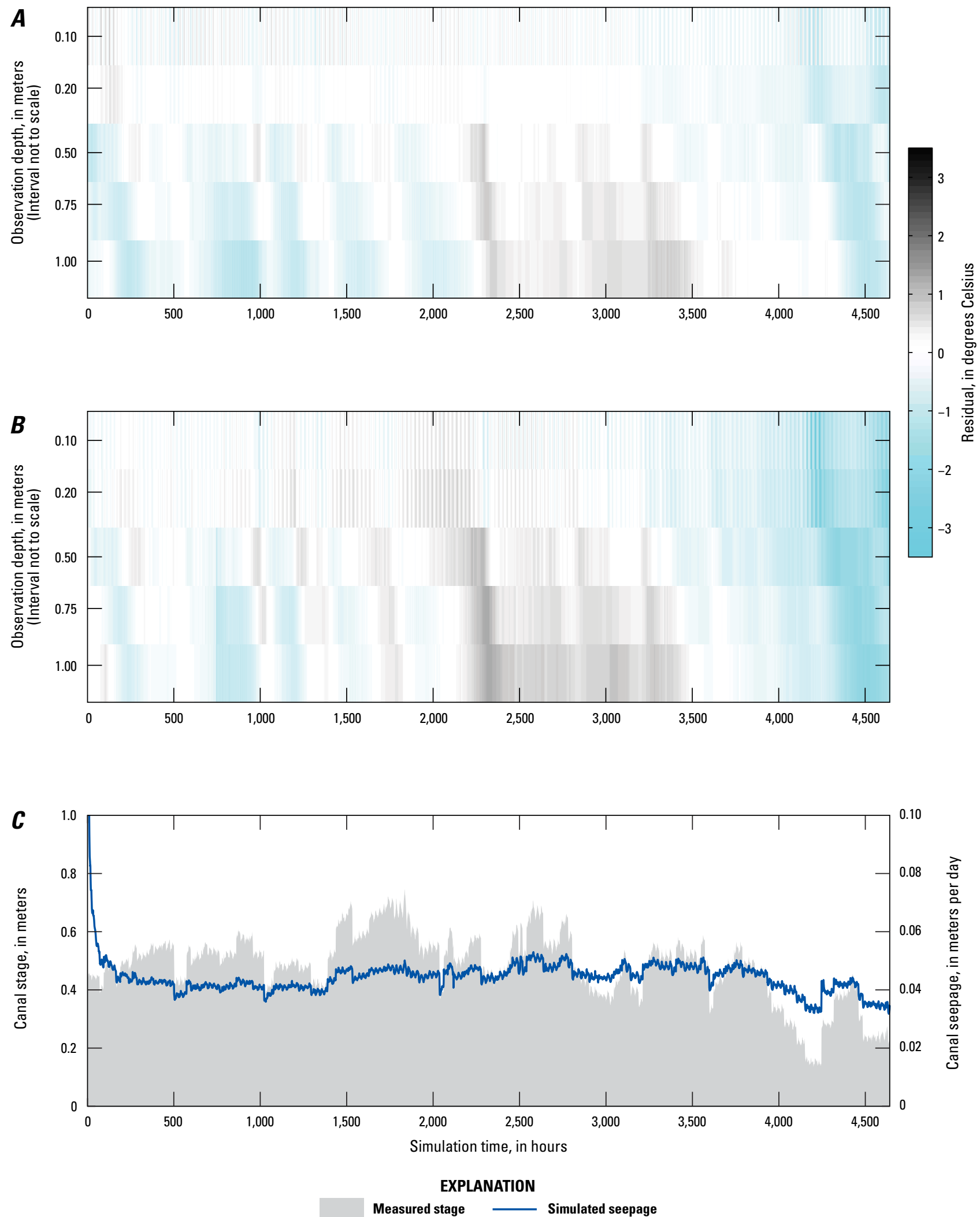

Figure 1A-6. Temperature residual for each depth below the canal at location $A, T 10$ and B, T14, and C, measured stage and simulated seepage for the 2012 prediction period. 

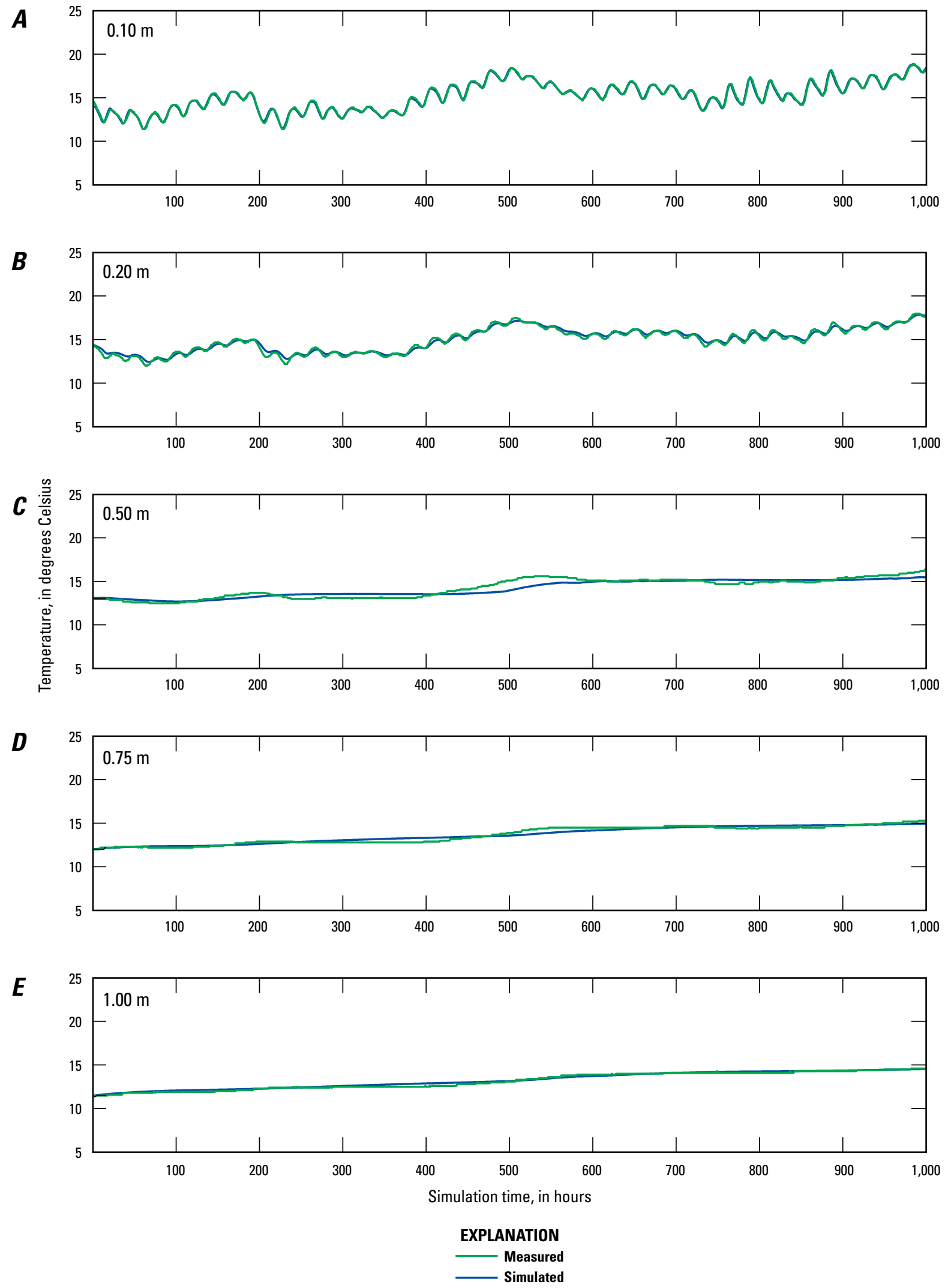

Figure 1A-7. Measured and simulated thermographs for canal sediments for T10 at depths of $A, 0.10 \mathrm{~m}, B, 0.20 \mathrm{~m}, \mathrm{C}, 0.50 \mathrm{~m}, \mathrm{D}, 0.75 \mathrm{~m}$, and $\mathrm{E}, 1.0 \mathrm{~m}$ for the 2013 calibration period. 

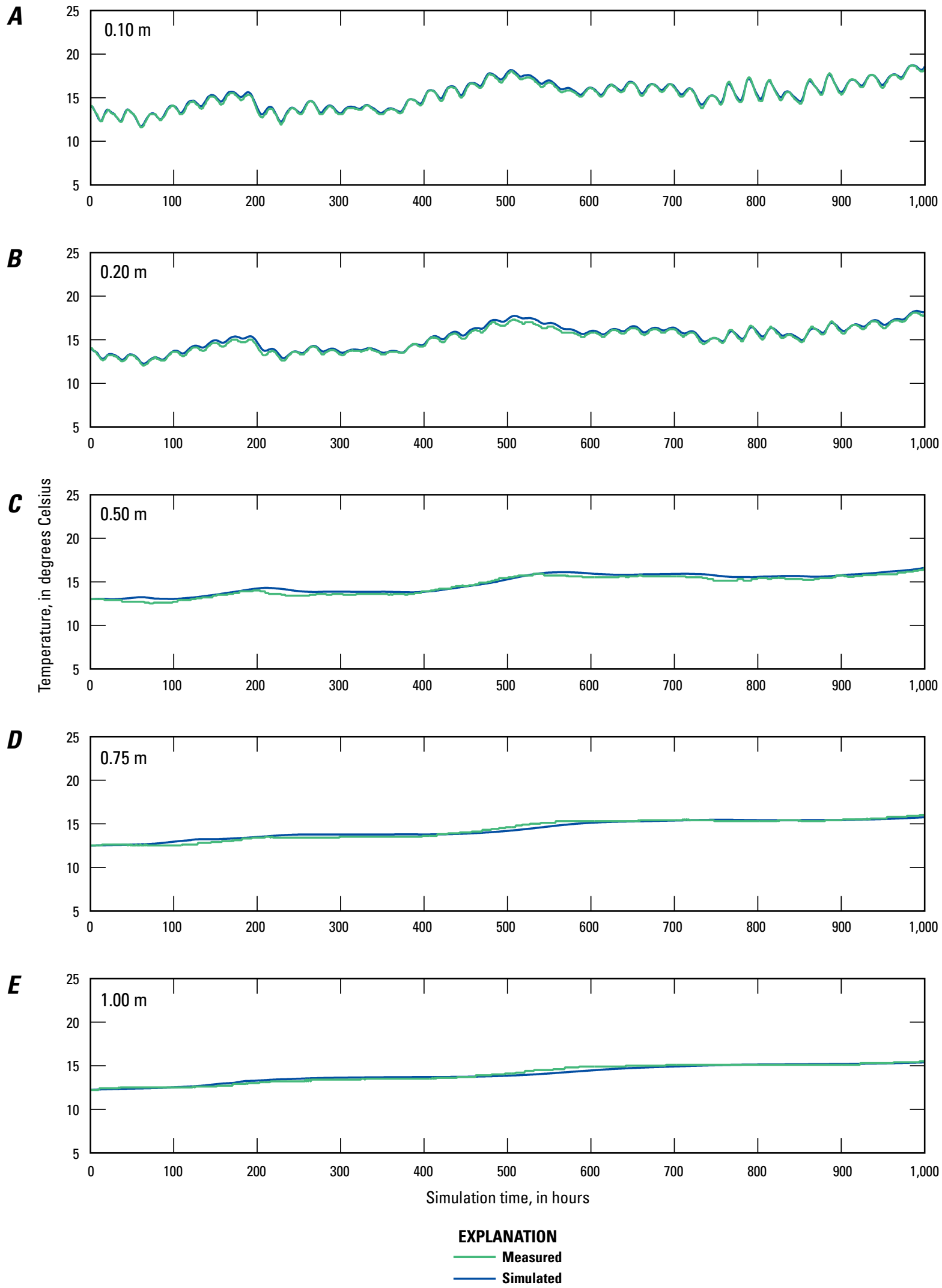

Figure 1A-8. Measured and simulated thermographs for canal sediments for T14 at depths of $A, 0.10 \mathrm{~m}, \mathrm{~B}, 0.20 \mathrm{~m}, \mathrm{C}, 0.50 \mathrm{~m}, \mathrm{D}, 0.75 \mathrm{~m}$, and $\mathrm{E}, 1.0 \mathrm{~m}$ for the 2013 calibration period. 

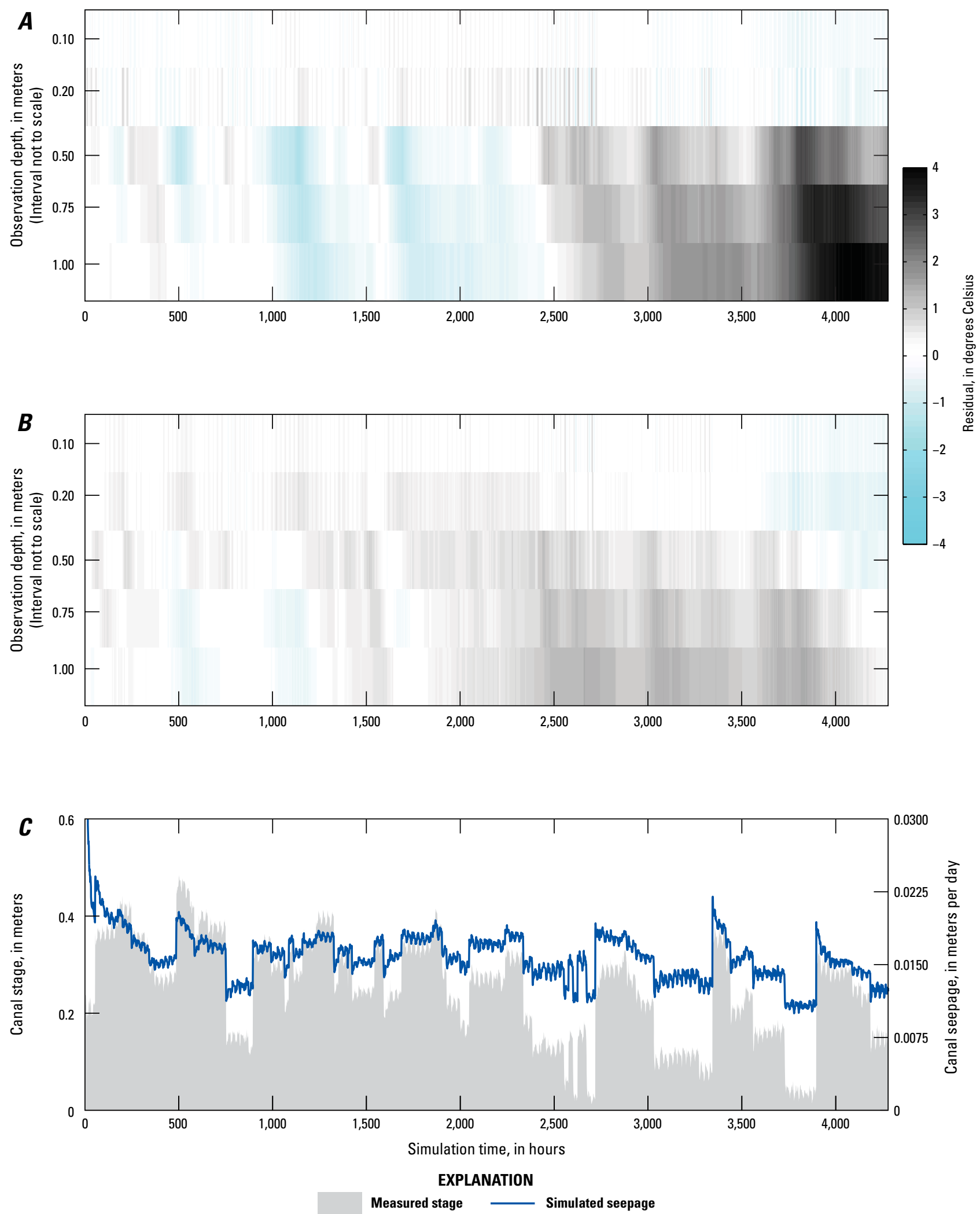

Figure 1A-9. Temperature residual for each depth below the canal at location $A, T 10$ and $B, T 14$, and $C$, measured stage and simulated seepage for the 2013 prediction period. 


\section{Appendix 1A Temperature and Model Results for Saroni Canal 1.1, Smith Valley, Nevada}

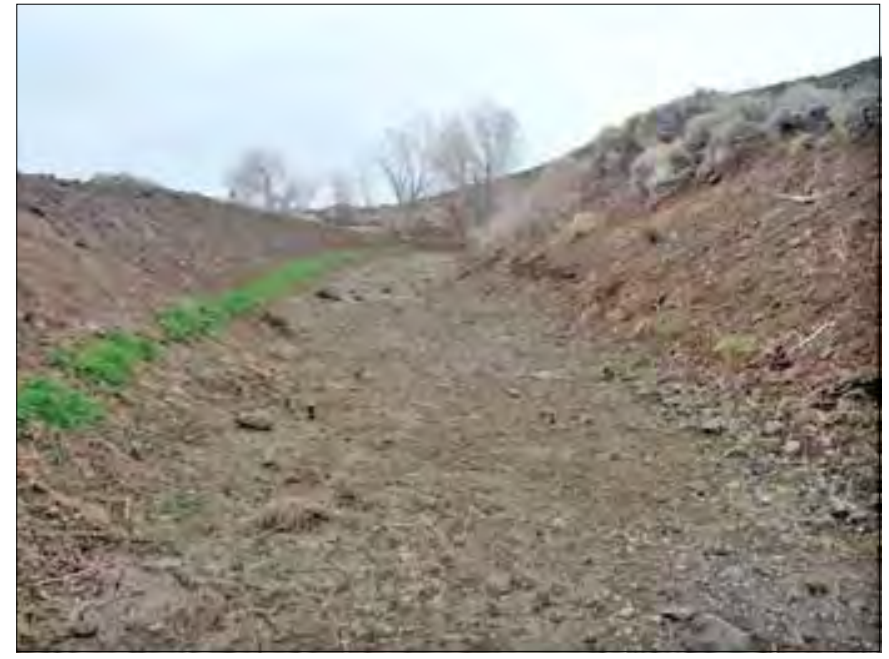

Figure 1A-10. Photograph of SARONI CANAL 1.1 site, Wellington, Nevada. Photograph taken by David W. Smith, U.S. Geological Survey, looking downstream on 4/8/2013.

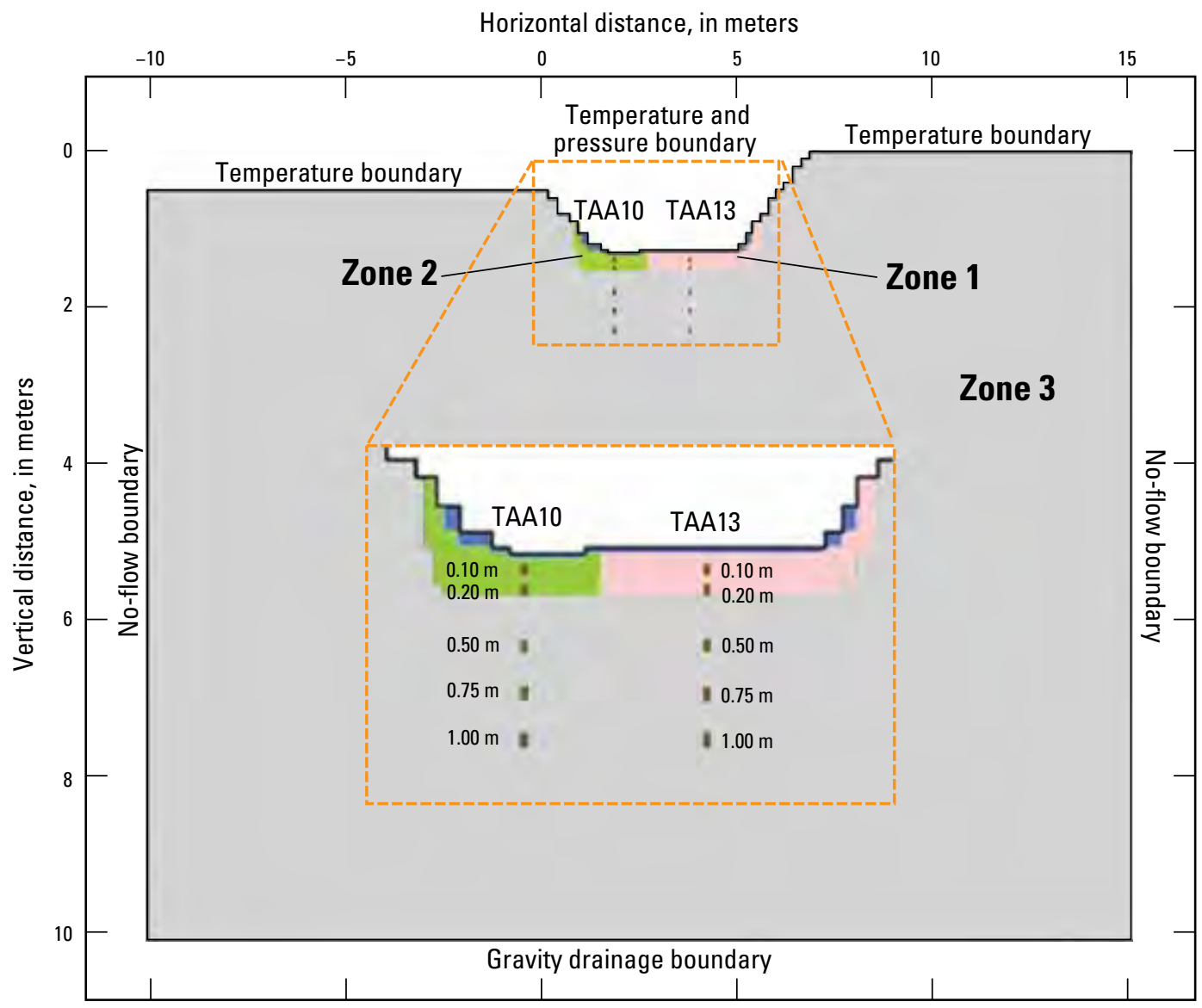

Figure 1A-11. Schematic cross section of two-dimensional VS2DH model of water and heat transport through canal-bed sediments at SARONI CANAL 1.1 site with soil textural zones (Zones 1-3), locations of temperature observations below ground surface within the canal (TAA10 and TAA13), and specified vertical and horizontal boundary conditions. 

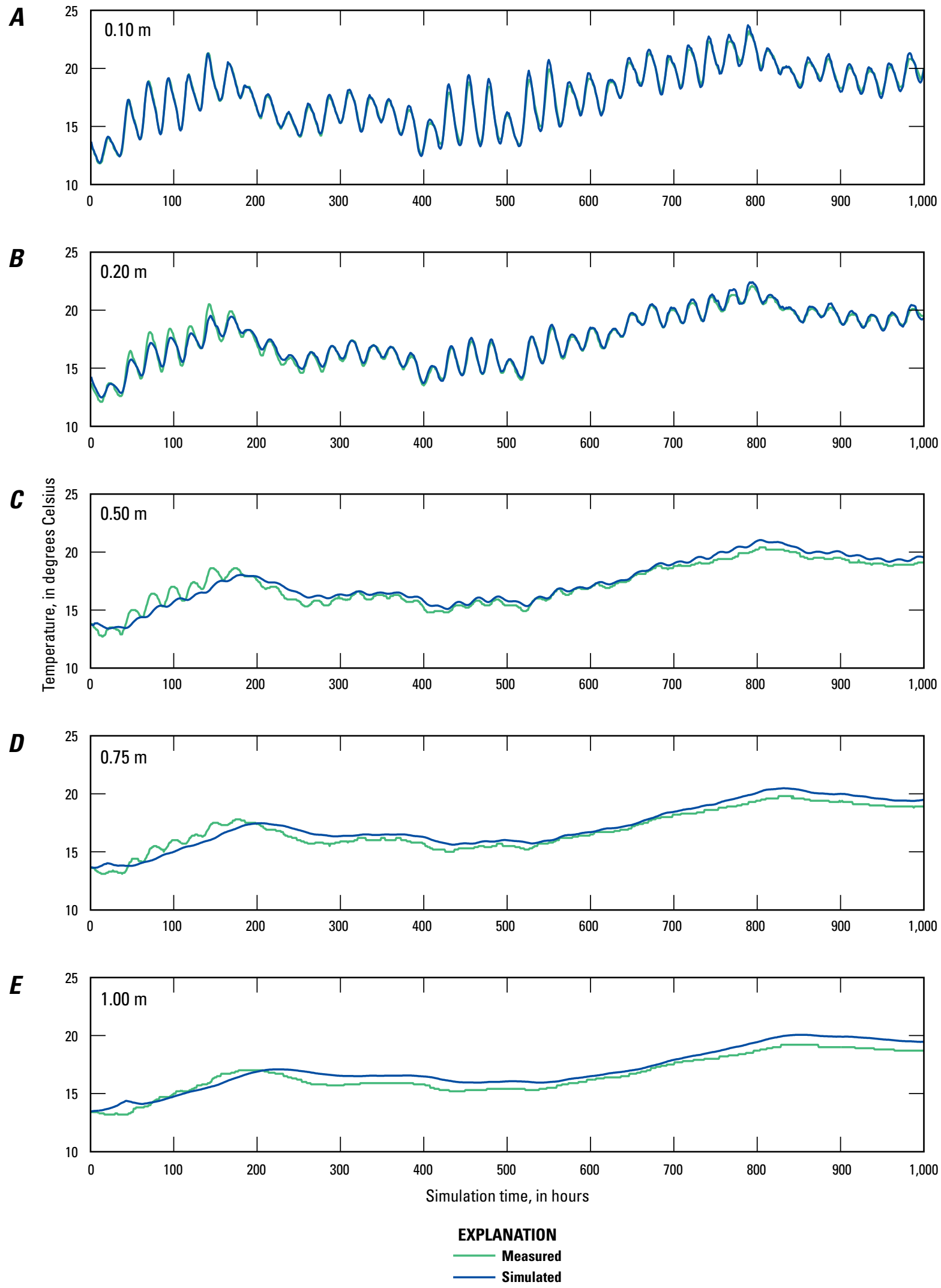

Figure 1A-12. Measured and simulated thermographs for canal sediments for TAA10 at depths of $A, 0.10 \mathrm{~m}, \mathrm{~B}, 0.20 \mathrm{~m}, \mathrm{C}, 0.50 \mathrm{~m}$, $\mathrm{D}, 0.75 \mathrm{~m}$, and $\mathrm{E}, 1.0 \mathrm{~m}$ for the 2013 calibration period. 
$\boldsymbol{A}$

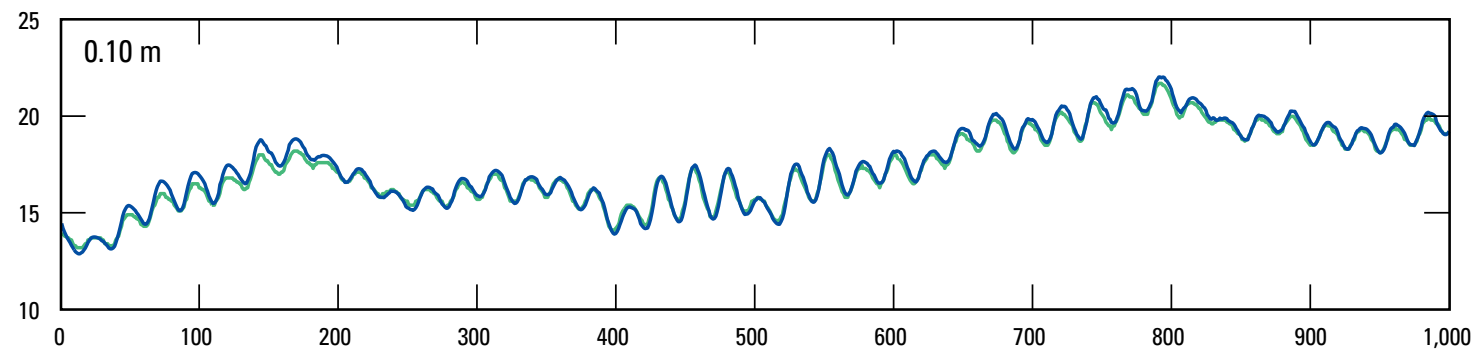

B
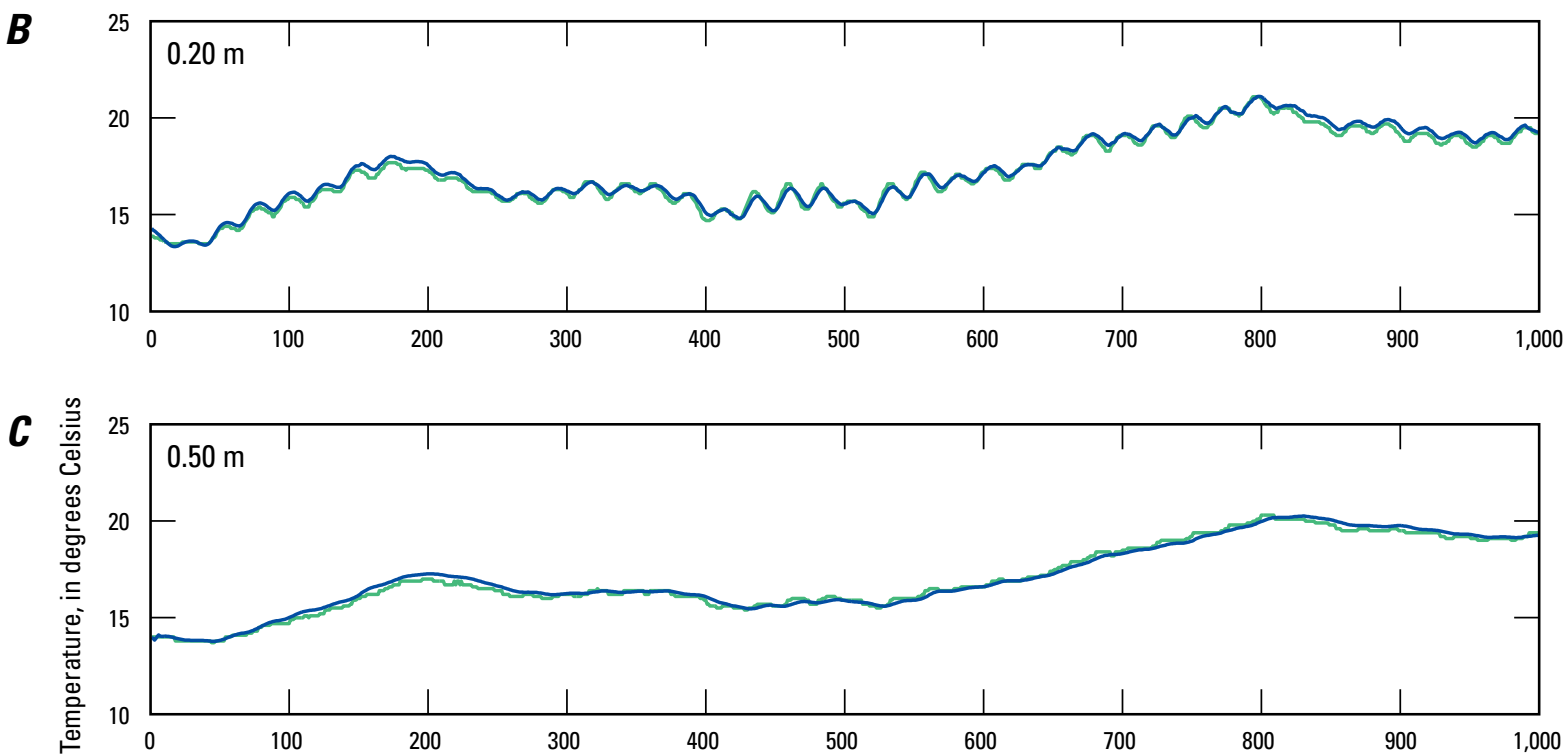

D

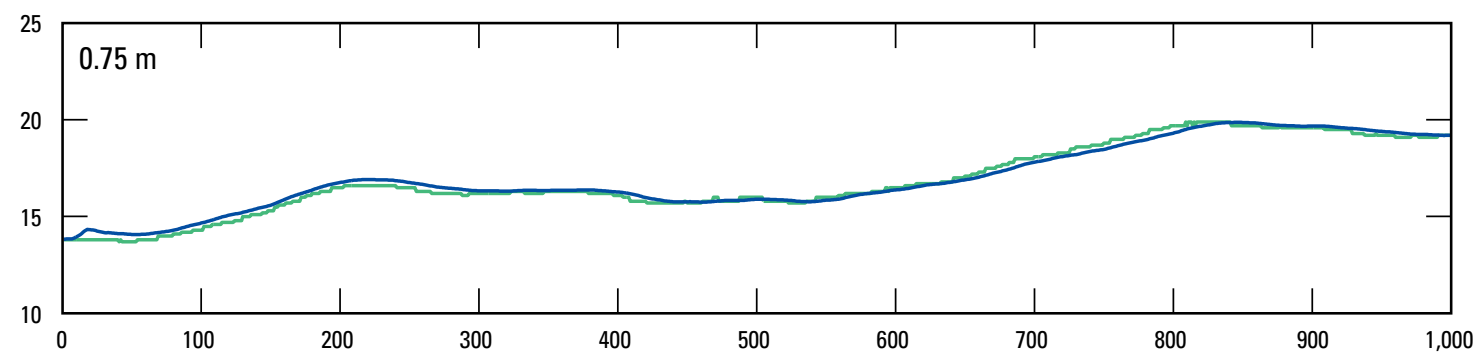

$E$

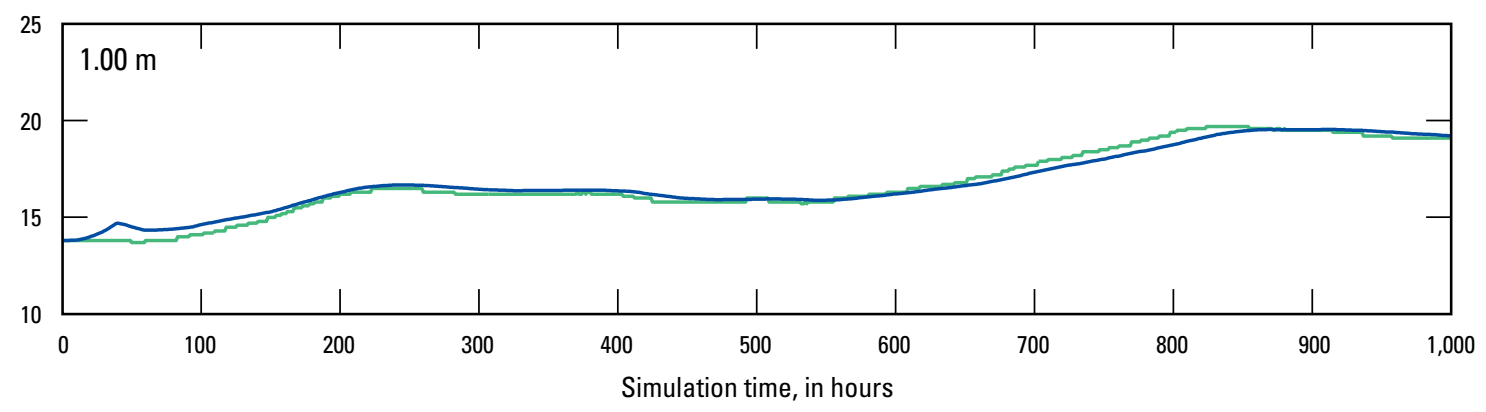

EXPLANATION

Measured

Figure 1A-13. Measured and simulated thermographs for canal sediments for TAA13 at depths of $A, 0.10 \mathrm{~m}, B, 0.20 \mathrm{~m}, \mathrm{C}, 0.50 \mathrm{~m}$, $\mathrm{D}, 0.75 \mathrm{~m}$, and $\mathrm{E}, 1.0 \mathrm{~m}$ for the 2013 calibration period. 

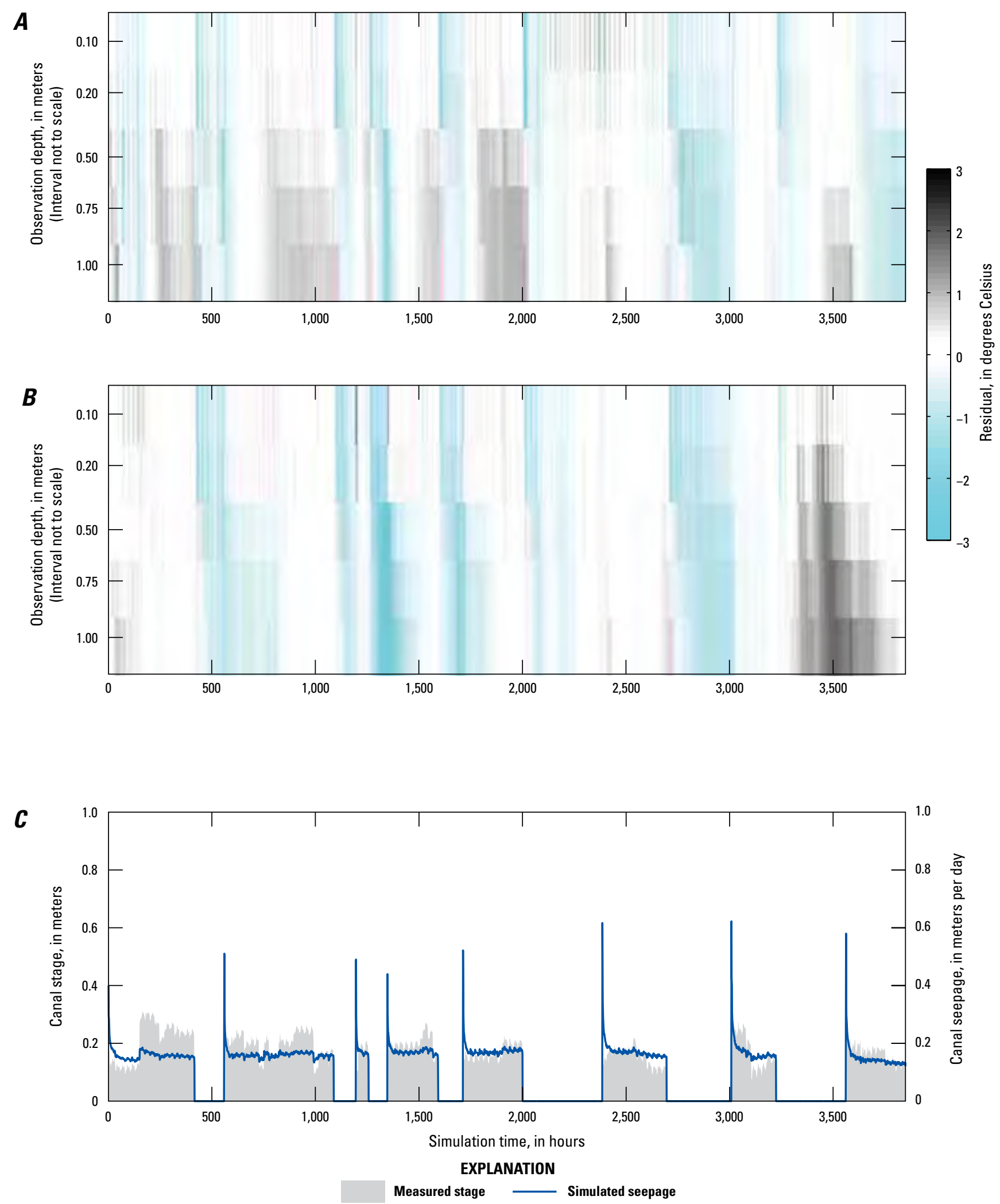

Figure 1A-14. Temperature residual for each depth below the canal at location A, TAA10 and B, TAA13, and C, measured stage and simulated seepage for the 2013 prediction period. 


\section{Appendix 1A Temperature and Model Results for Saroni Canal 1.2, Smith Valley, Nevada}

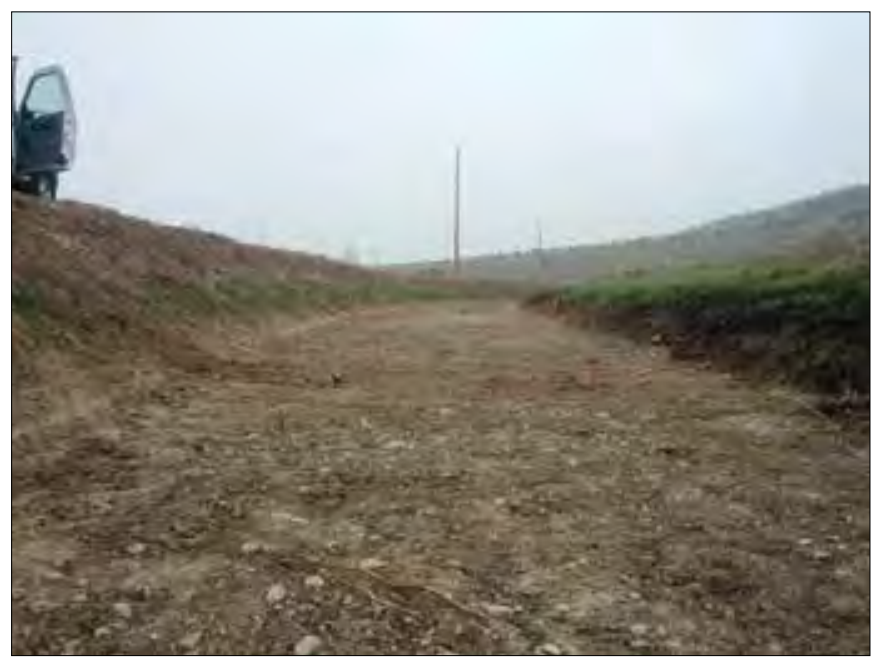

Figure 1A-15. Photograph of SARONI CANAL 1.2 site, Wellington, Nevada. Photograph taken by David W. Smith, U.S. Geological Survey, looking downstream on 4/8/2013.

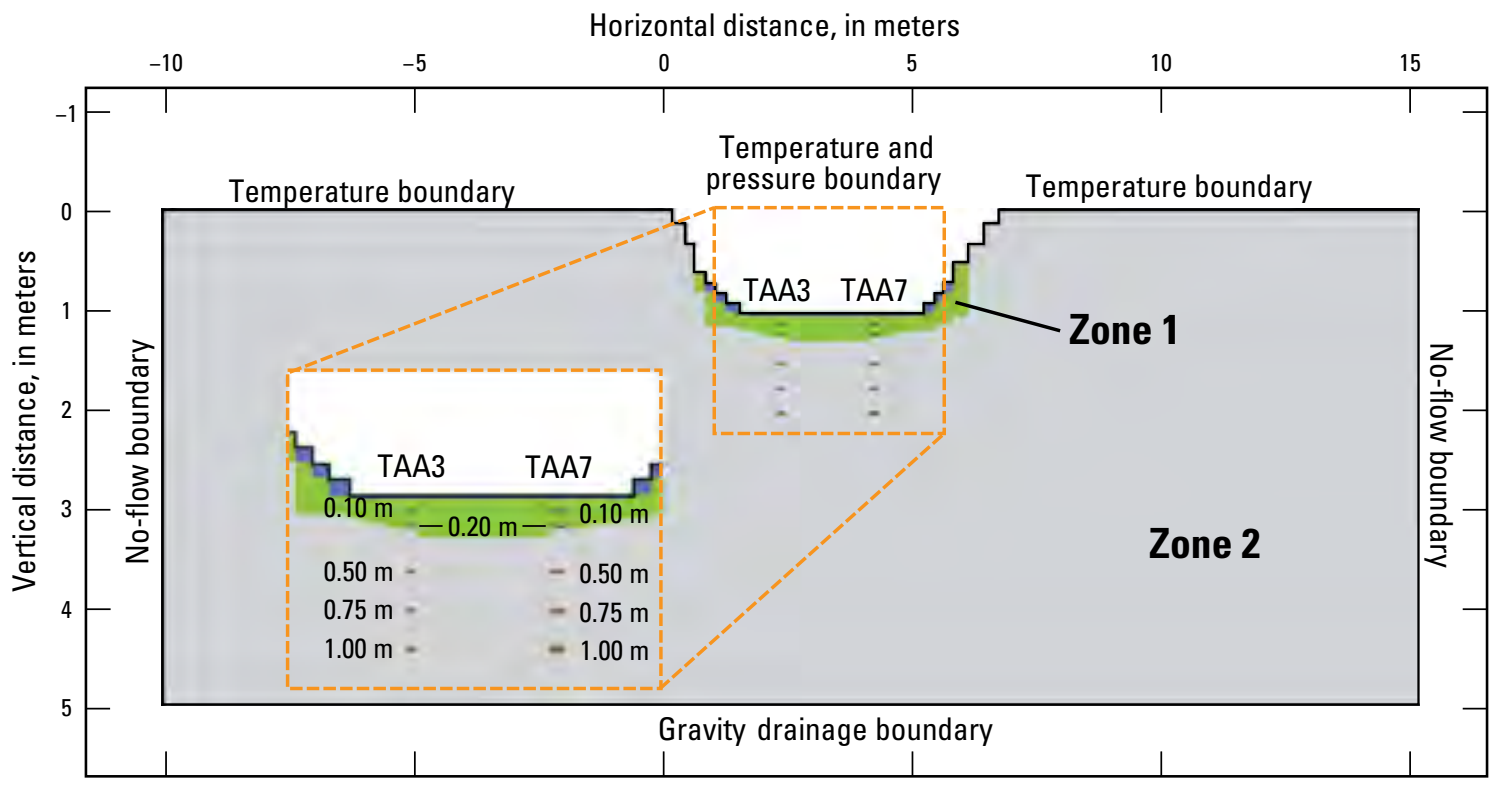

Figure 1A-16. Schematic cross section of two-dimensional VS2DH model of water and heat transport through canal-bed sediments at SARONI CANAL 1.2 site with soil textural zones (Zones 1-2), locations of temperature observations below ground surface within the canal (TAA3 and TAA7), and specified vertical and horizontal boundary conditions. 

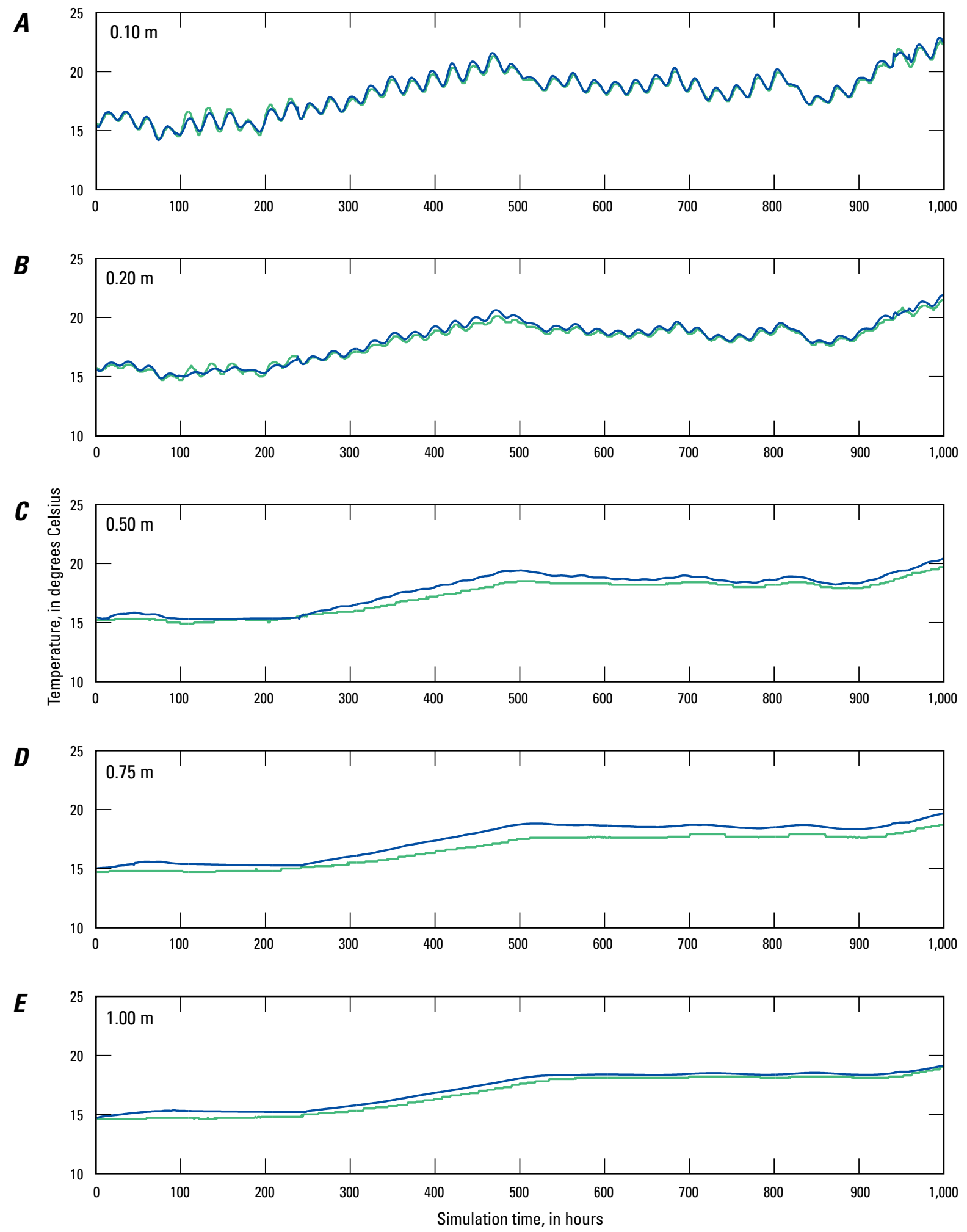

EXPLANATION

Measured

Simulated

Figure 1A-17. Measured and simulated thermographs for canal sediments for TAA3 at depths of $A, 0.10 \mathrm{~m}, B, 0.20 \mathrm{~m}, \mathrm{C}, 0.50 \mathrm{~m}$, $\mathrm{D}, 0.75 \mathrm{~m}$, and $\mathrm{E}, 1.0 \mathrm{~m}$ for the 2013 calibration period. 

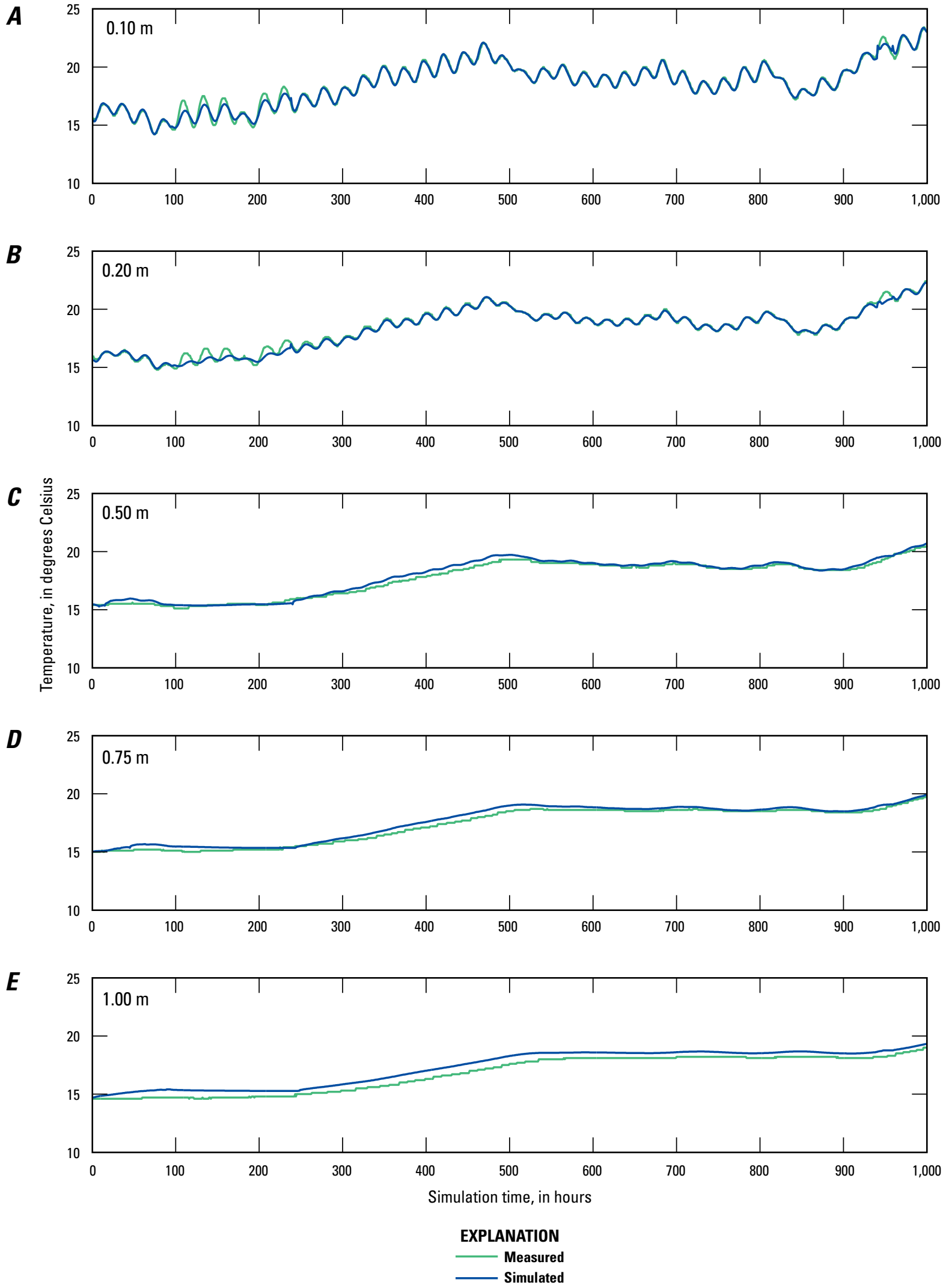

Figure 1A-18. Measured and simulated thermographs for canal sediments for TAA7 at depths of $A, 0.10 \mathrm{~m}, B, 0.20 \mathrm{~m}, C, 0.50 \mathrm{~m}$, $\mathrm{D}, 0.75 \mathrm{~m}$, and $\mathrm{E}, 1.0 \mathrm{~m}$ for the 2013 calibration period. 

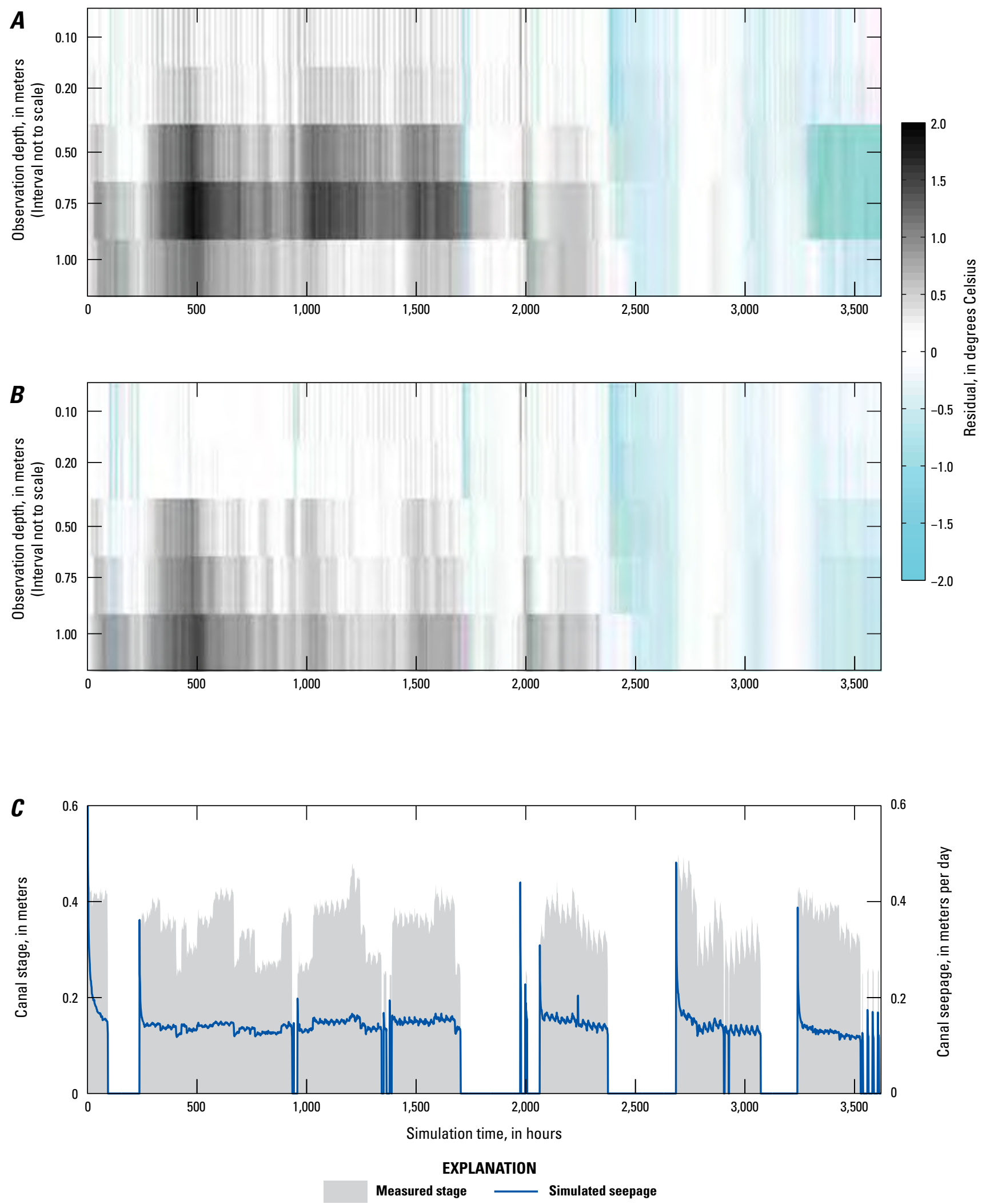

Figure 1A-19. Temperature residual for each depth below the canal at location $A, T A A 3$ and $B, T A A 7$, and $C$, measured stage and simulated seepage for the 2013 prediction period. 


\section{Appendix 1A Temperature and Model Results for Saroni Canal 1.3, Smith Valley, Nevada}

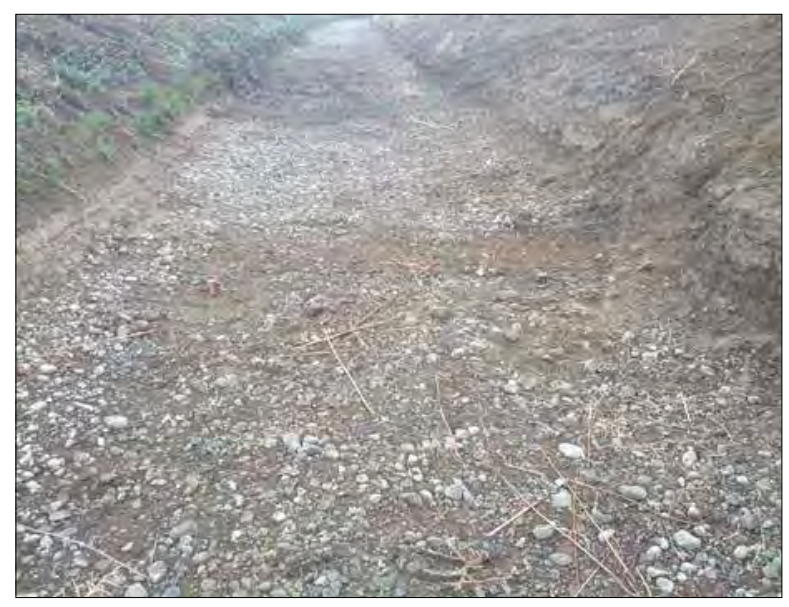

Figure 1A-20. Photograph of SARONI CANAL 1.3 site, Wellington, Nevada. Photograph taken by David W. Smith, U.S. Geological Survey, looking downstream on 4/8/2013.

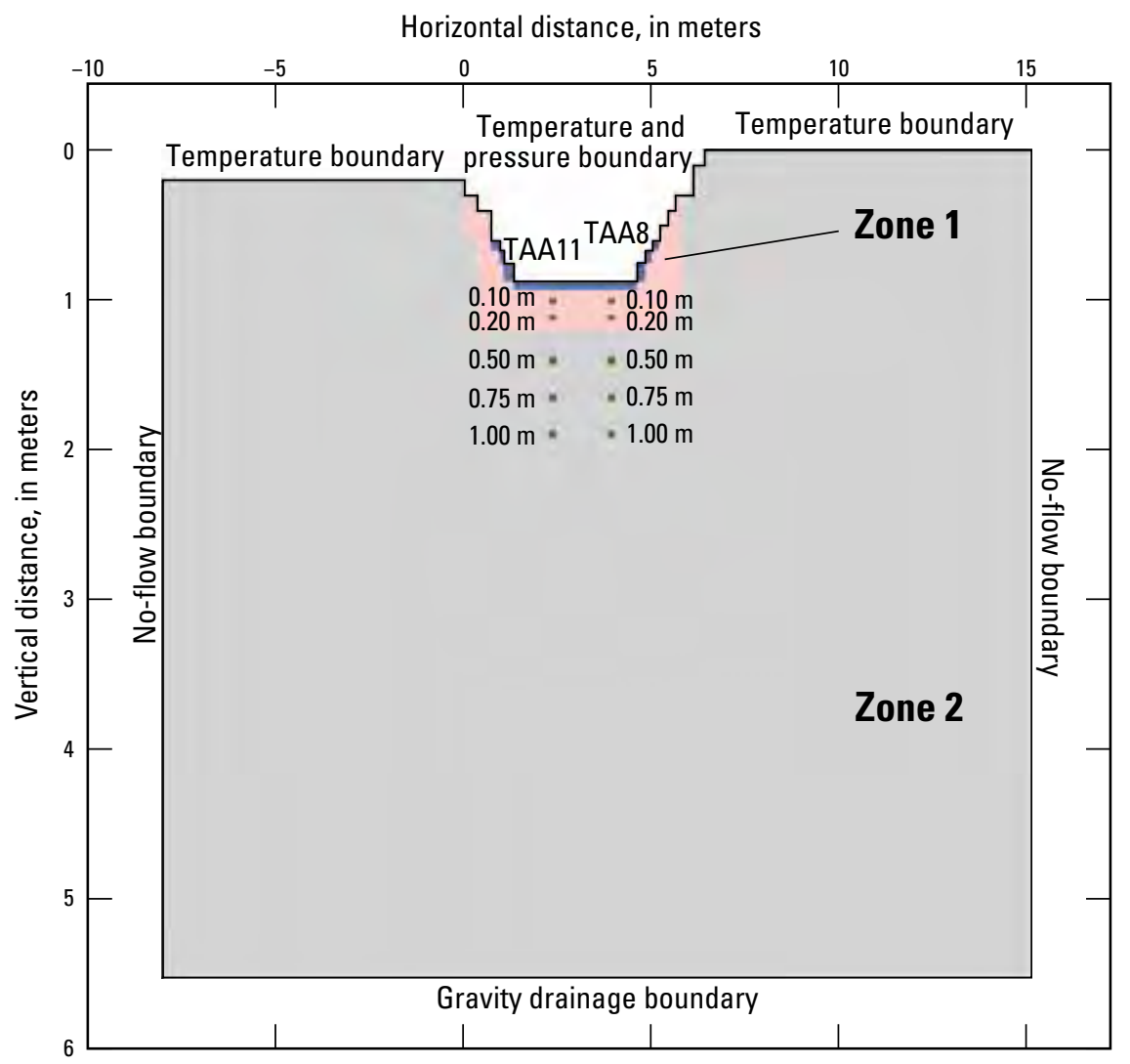

Figure 1A-21. Schematic cross section of two-dimensional VS2DH model of water and heat transport through canal-bed sediments at SARONI CANAL 1.3 site with soil textural zones (Zones 1-2), locations of temperature observations below ground surface within the canal (TAA8 and TAA11), and specified vertical and horizontal boundary conditions. 

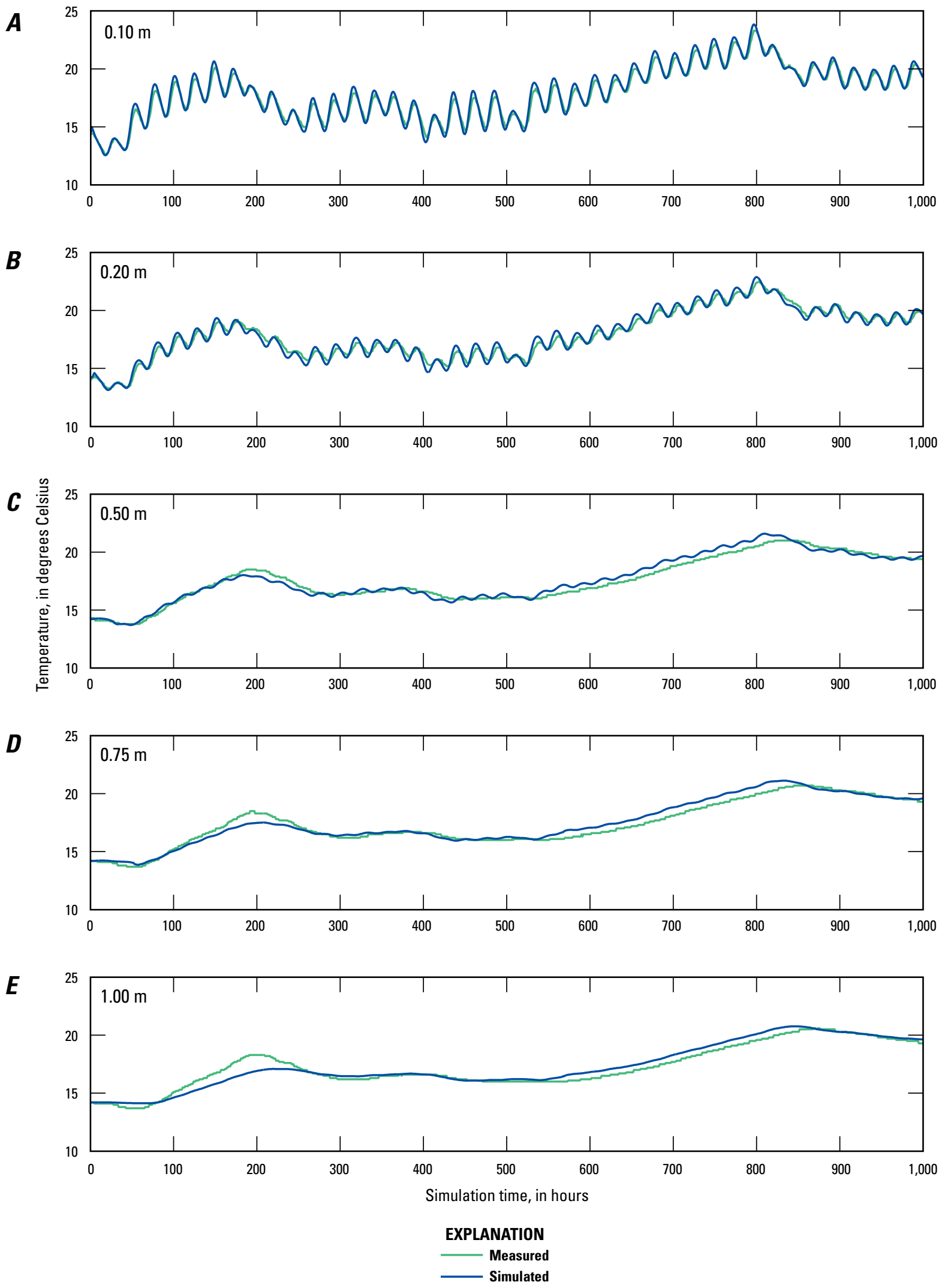

Figure A1-22. Measured and simulated thermographs for canal sediments for TAA8 at depths of $A, 0.10 \mathrm{~m}, \mathrm{~B}, 0.20 \mathrm{~m}, \mathrm{C}, 0.50 \mathrm{~m}$, $\mathrm{D}, 0.75 \mathrm{~m}$, and $\mathrm{E}, 1.0 \mathrm{~m}$ for the 2013 calibration period. 
$\boldsymbol{A}$

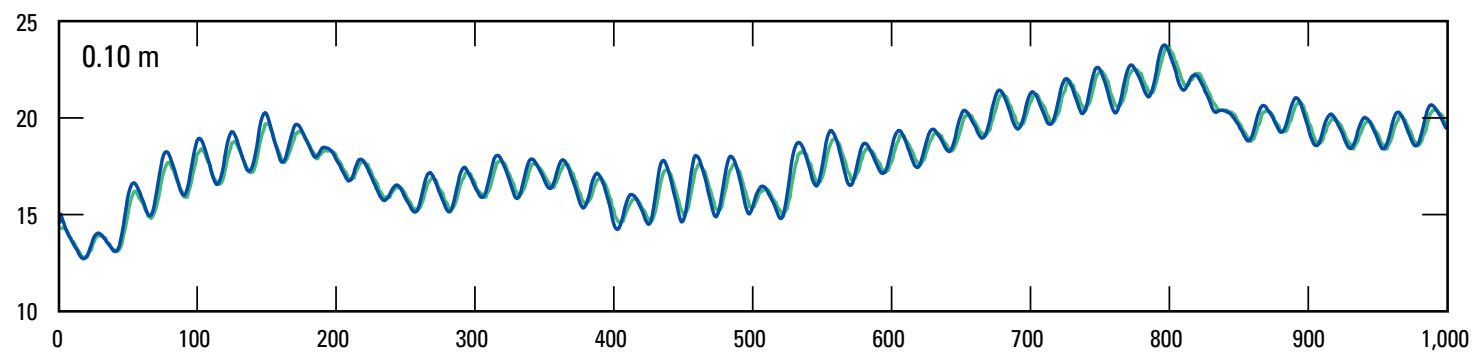

$B$
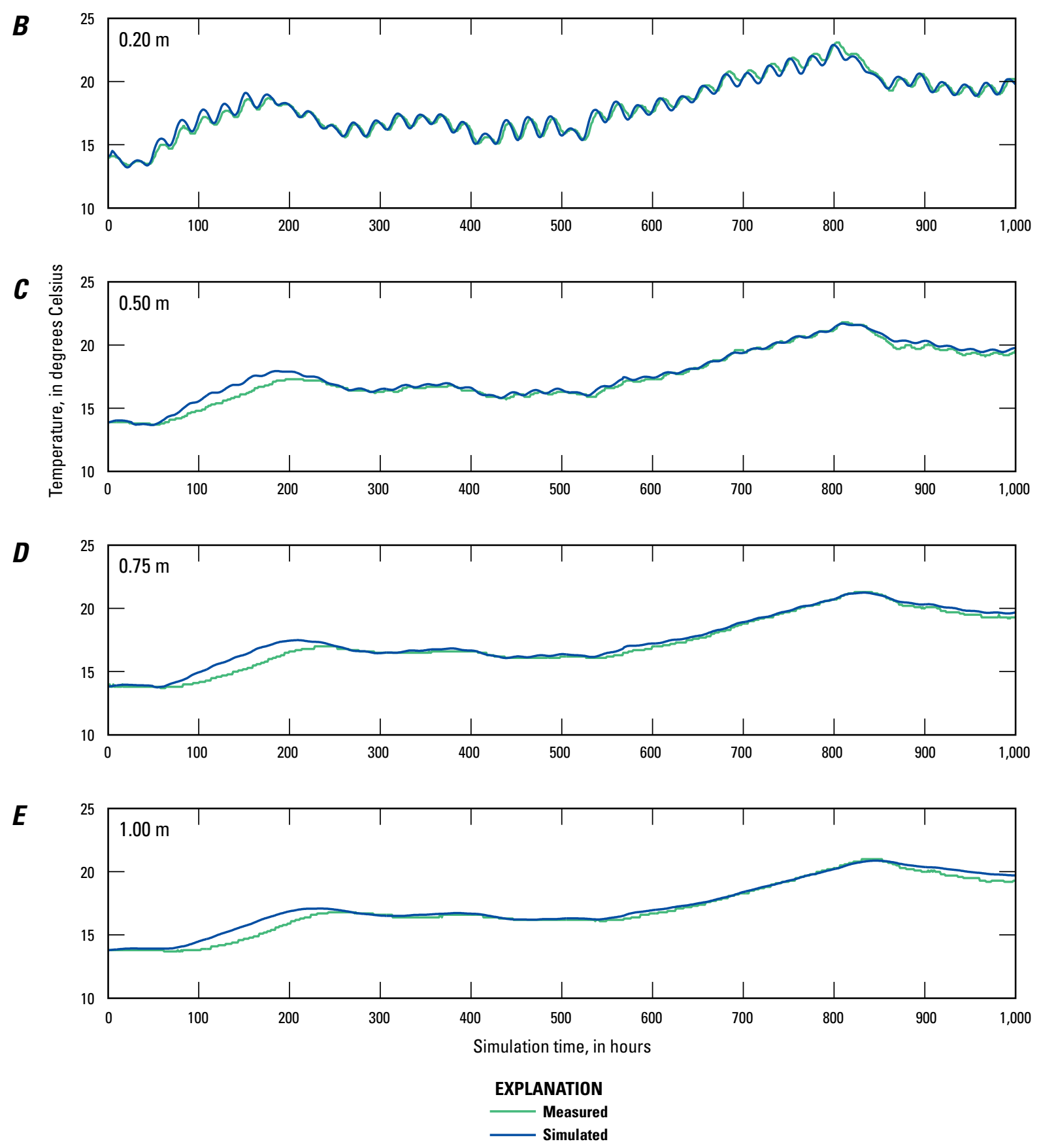

Figure 1A-23. Measured and simulated thermographs for canal sediments for TAA11 at depths of $A, 0.10 \mathrm{~m}, \mathrm{~B}, 0.20 \mathrm{~m}, \mathrm{C}, 0.50 \mathrm{~m}$, $\mathrm{D}, 0.75 \mathrm{~m}$, and $\mathrm{E}, 1.0 \mathrm{~m}$ for the 2013 calibration period. 

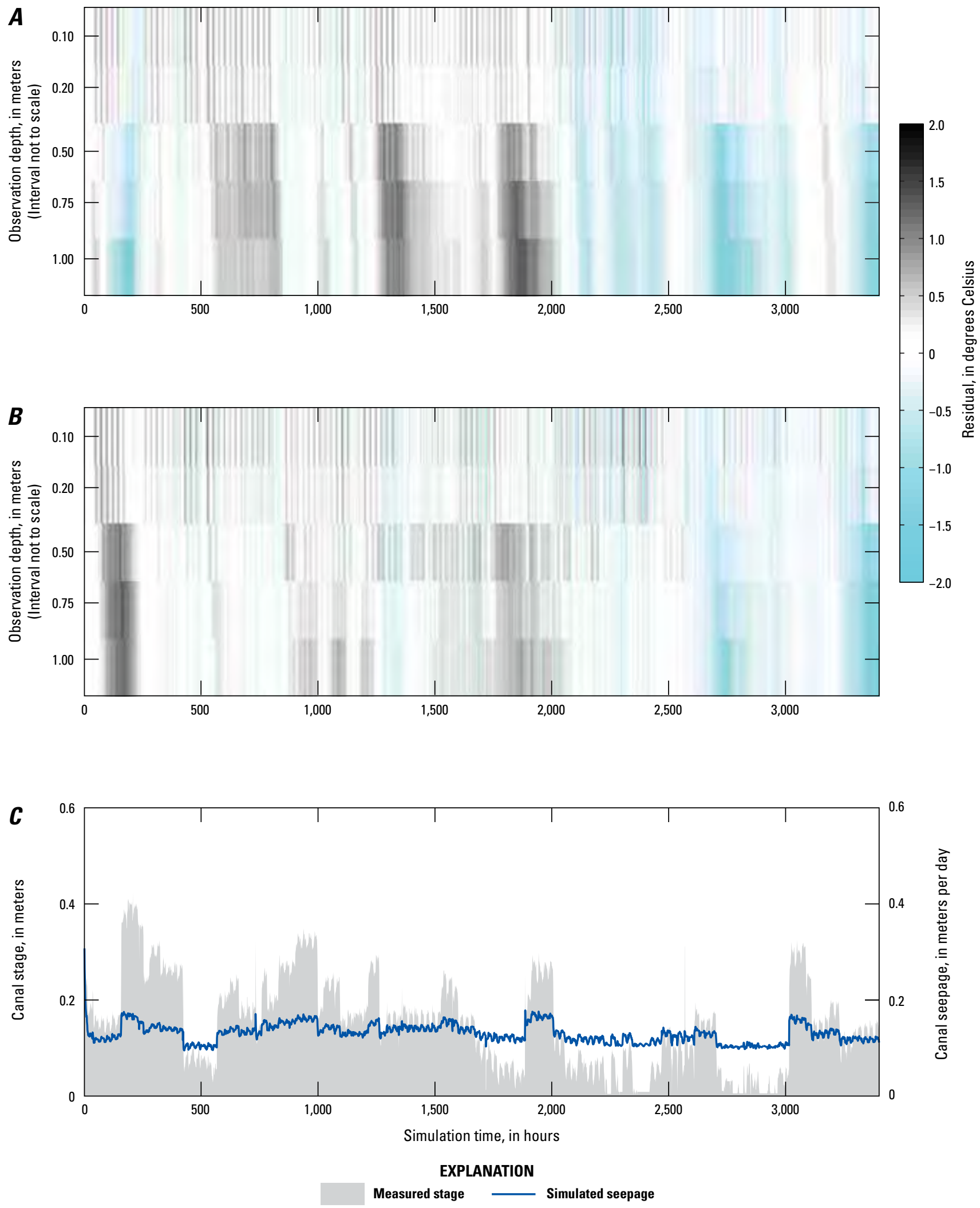

Figure 1A-24. Temperature residual for each depth below the canal at location A, TAA8 and B, TAA11, and C, measured stage and simulated seepage for the 2013 prediction period. 


\section{Appendix 1A Temperature and Model Results for Saroni Canal 2, Smith Valley, Nevada}

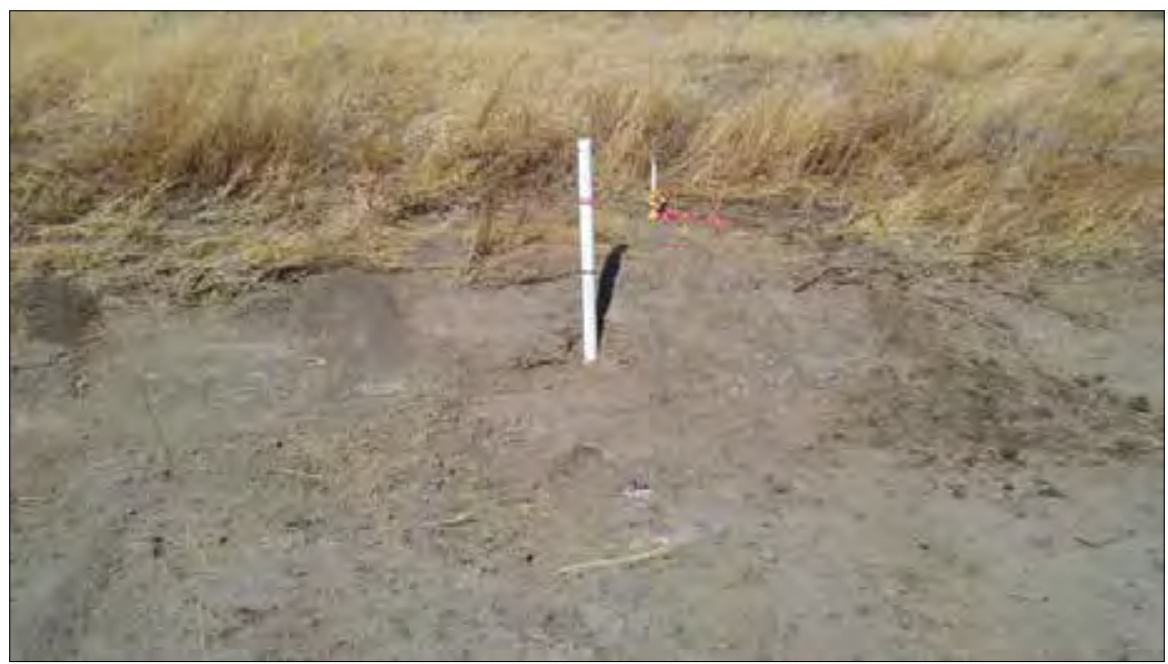

Figure 1A-25. Photograph of SARONI CANAL 2 site, Wellington, Nevada. Photograph taken by David W. Smith, U.S. Geological Survey. View of right stream bank on 3/12/2013.

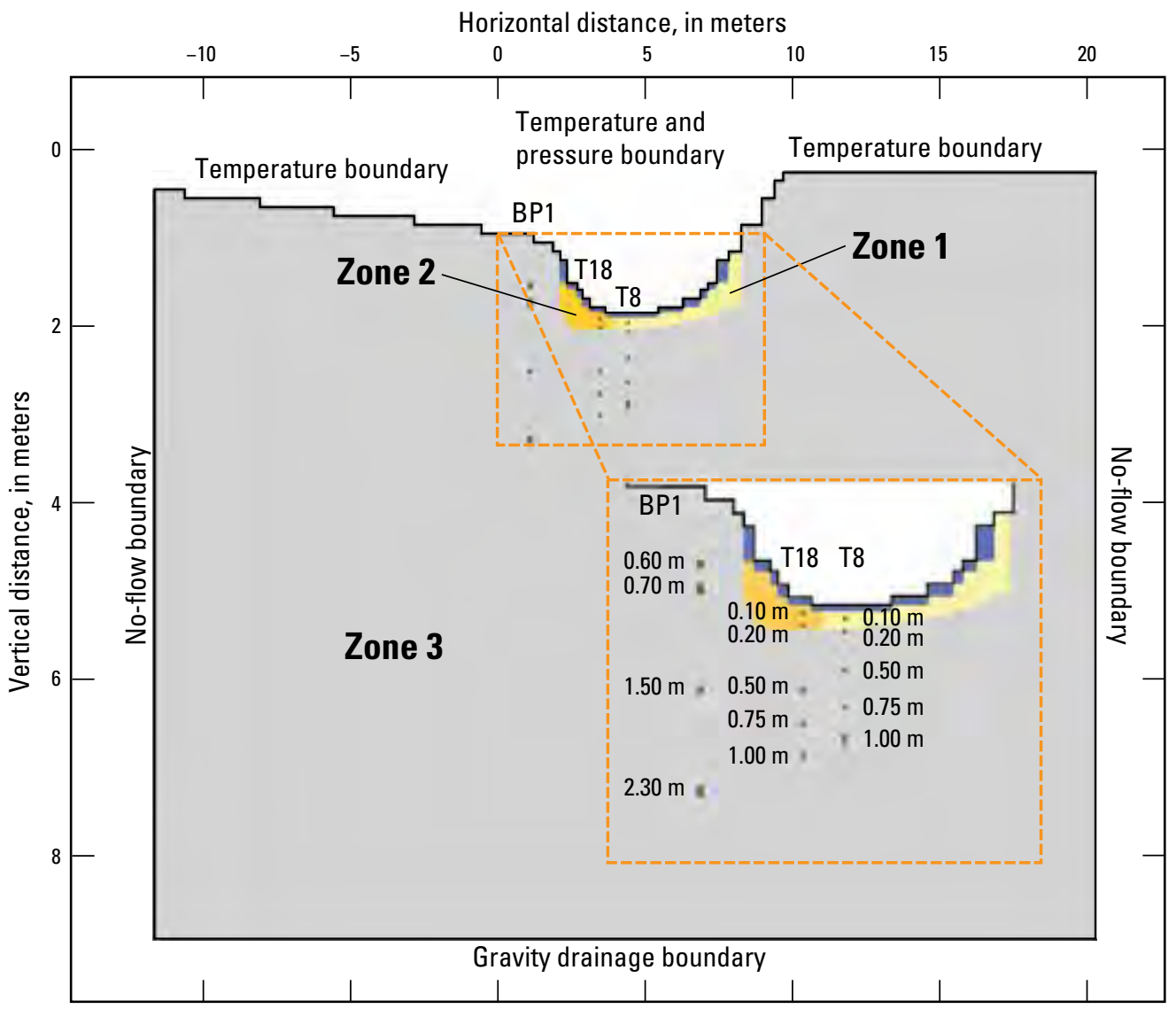

Figure 1A-26. Schematic cross section of two-dimensional VS2DH model of water and heat transport through canal-bed sediments at SARONI CANAL 2 site with soil textural zones (Zones 1-3), locations of temperature observations below ground surface within the canal (T8 and T18) and along the banks (BP1), and specified vertical and horizontal boundary conditions. 

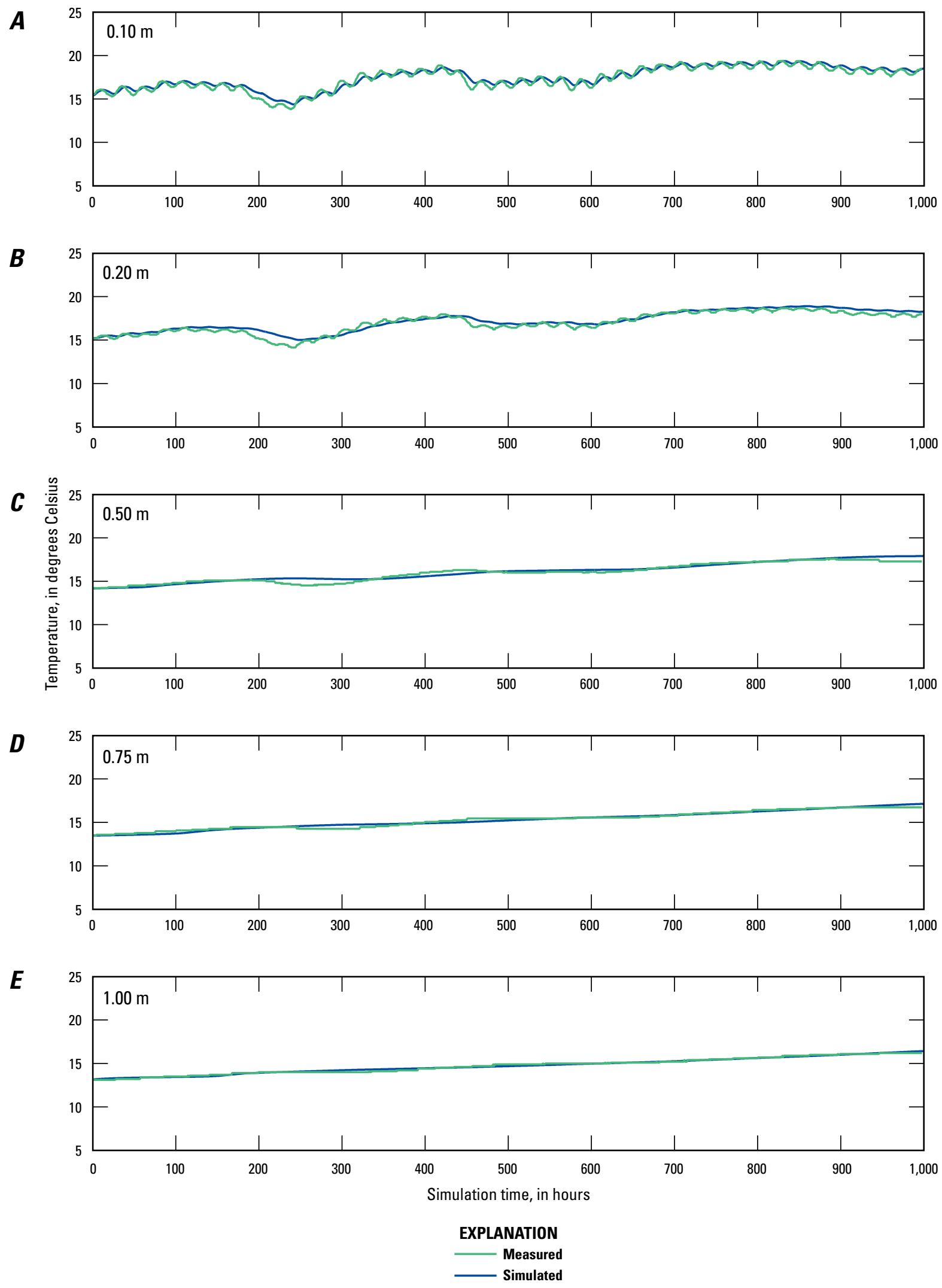

Figure 1A-27. Measured and simulated thermographs for canal sediments for T8 at depths of $A, 0.10 \mathrm{~m}, \mathrm{~B}, 0.20 \mathrm{~m}, \mathrm{C}, 0.50 \mathrm{~m}, \mathrm{D}, 0.75 \mathrm{~m}$, and $\mathrm{E}, 1.0 \mathrm{~m}$ for the 2012 calibration period. 

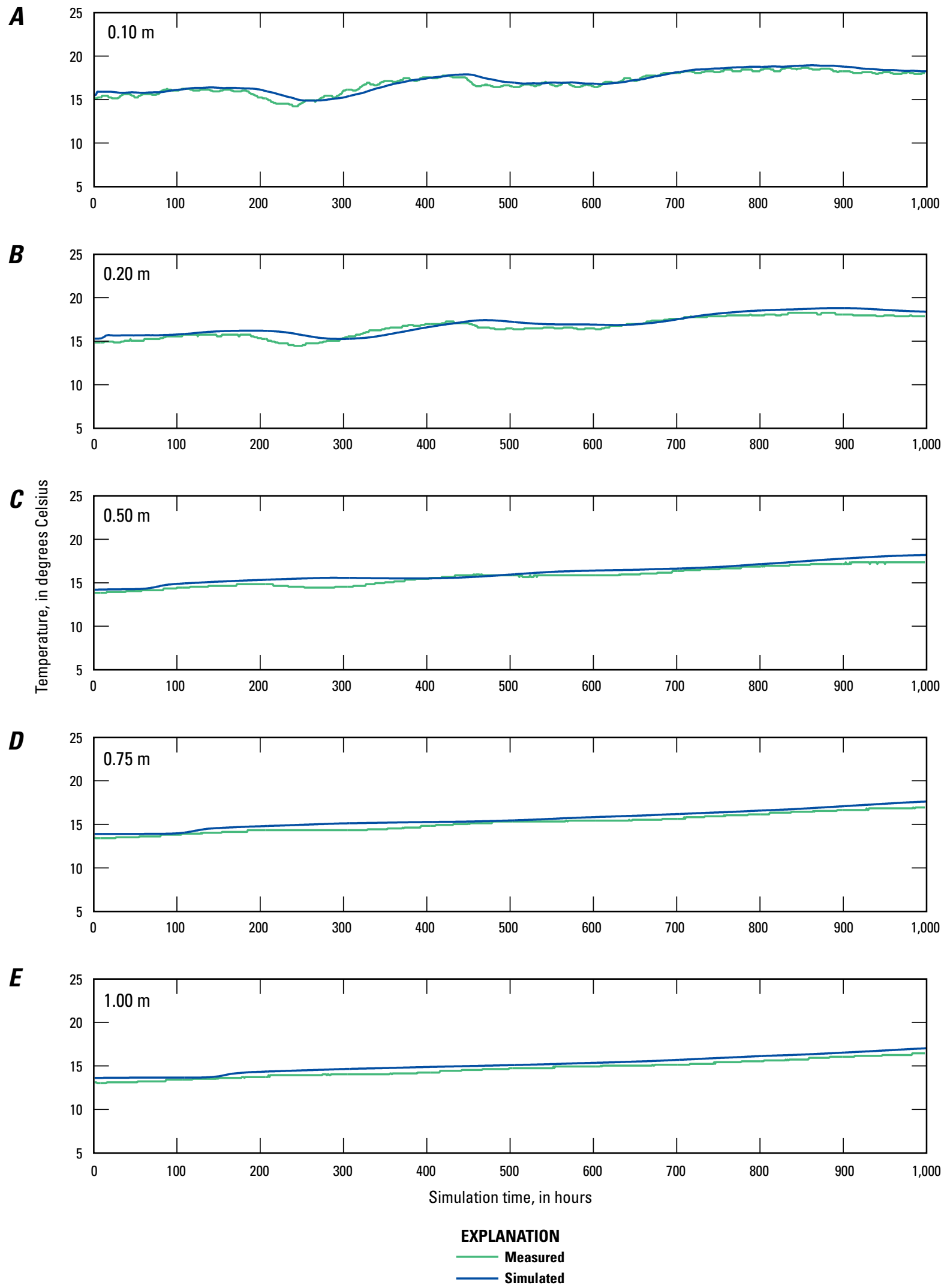

Figure 1A-28. Measured and simulated thermographs for canal sediments for T18 at depths of $A, 0.10 \mathrm{~m}, \mathrm{~B}, 0.20 \mathrm{~m}, \mathrm{C}, 0.50 \mathrm{~m}, \mathrm{D}, 0.75 \mathrm{~m}$, and $\mathrm{E}, 1.0 \mathrm{~m}$ for the 2012 calibration period. 

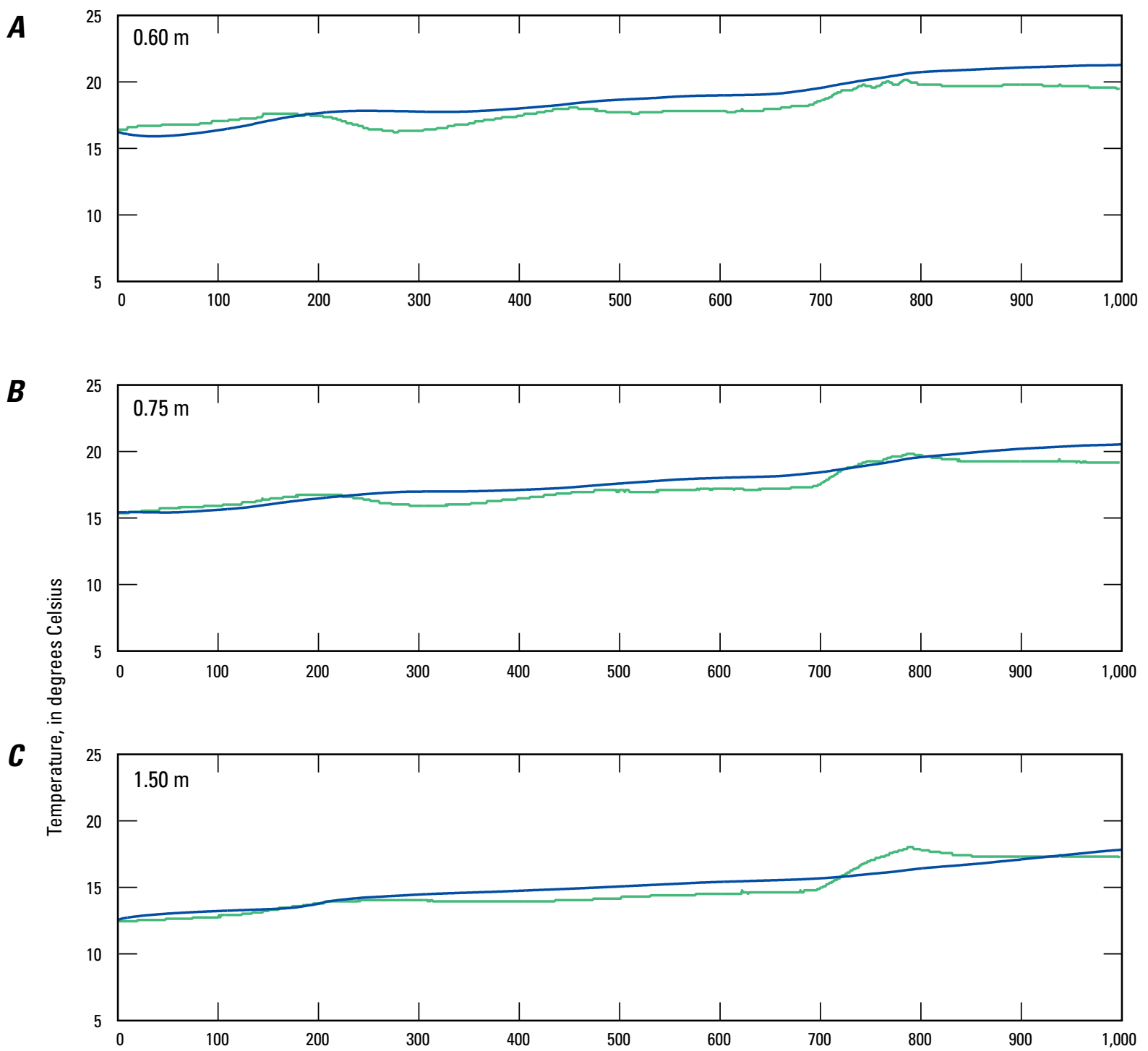

D

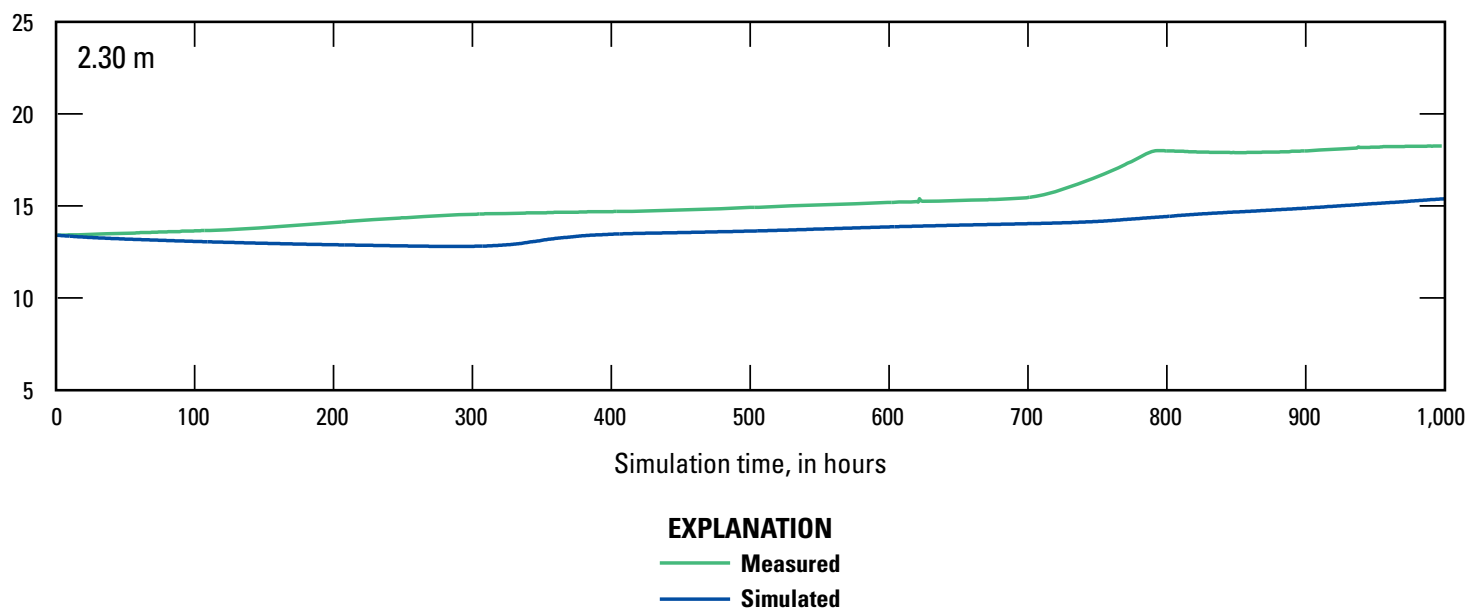

Figure 1A-29. Measured and simulated thermographs for Bank Piezometer 1 (BP1) at depths of A, 0.60 m, B, $0.75 \mathrm{~m}, \mathrm{C}, 1.50 \mathrm{~m}$, and D, $2.30 \mathrm{~m}$ for the 2012 calibration period. 

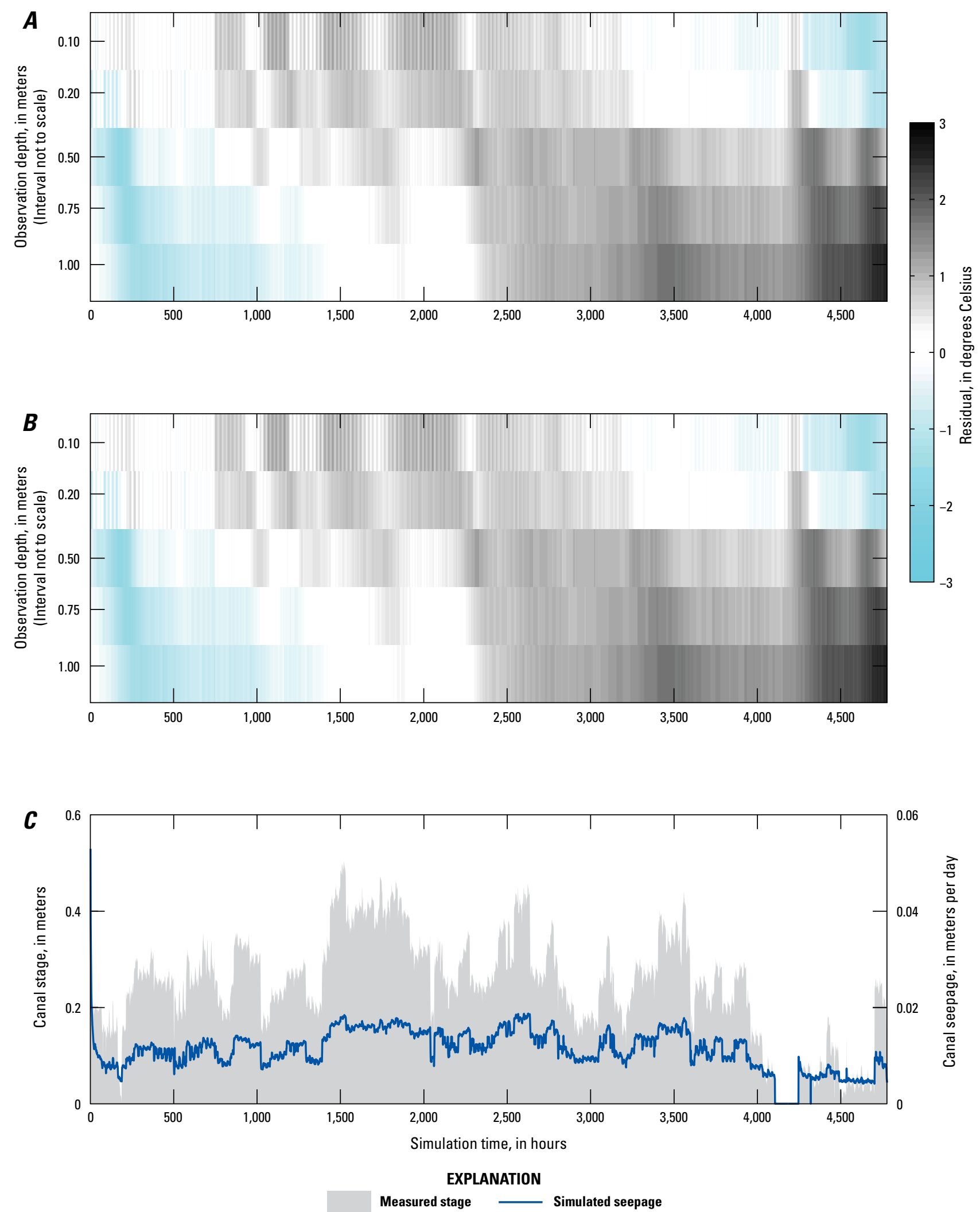

Figure 1A-30. Temperature residual for each depth below the canal at location $A, T 8$ and $B, T 18$, and $C$, measured stage and simulated seepage for the 2012 prediction period. 

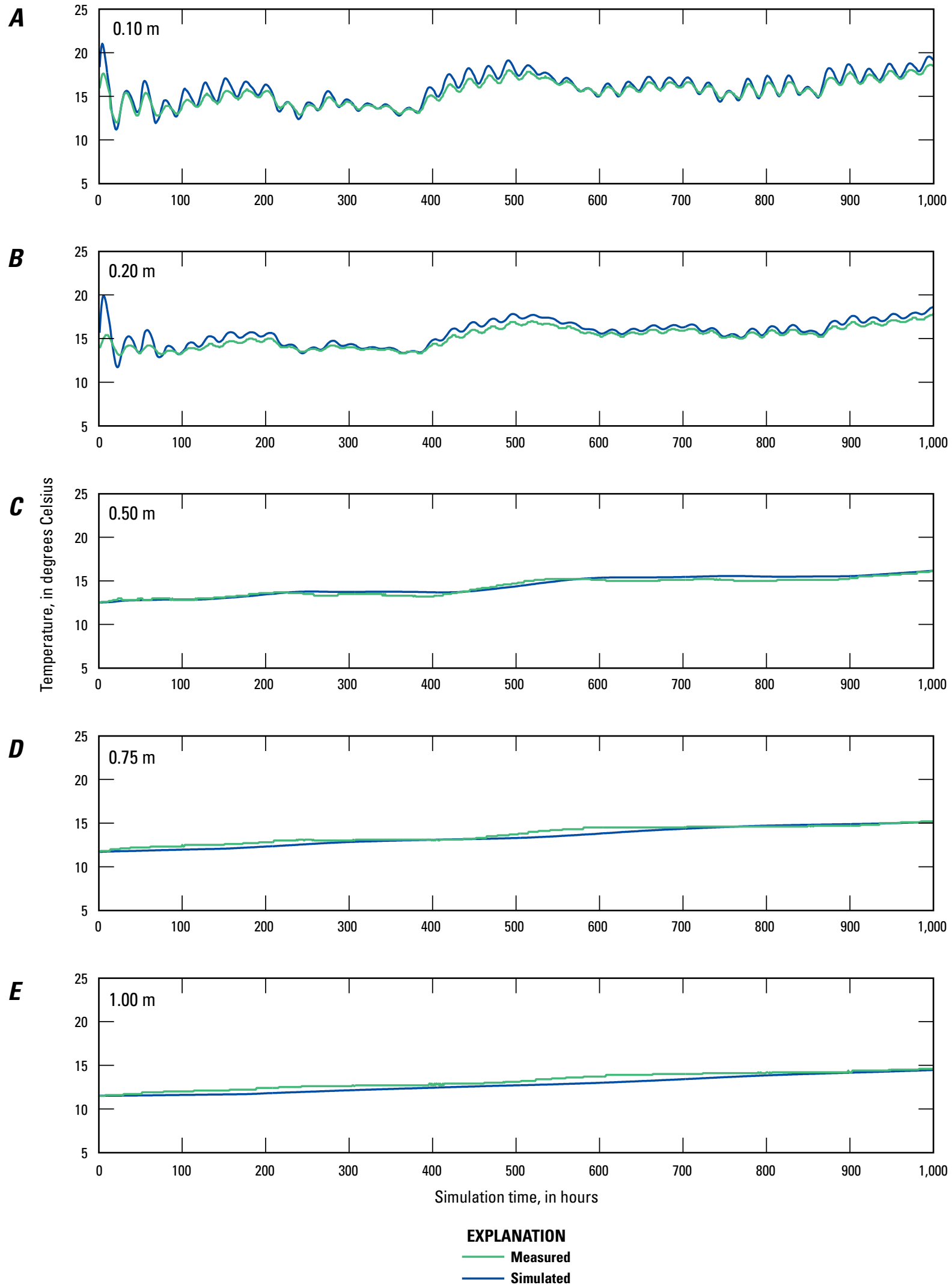

Figure 1A-31. Measured and simulated thermographs for canal sediments for T8 at depths of $A, 0.10 \mathrm{~m}, B, 0.20 \mathrm{~m}, \mathrm{C}, 0.50 \mathrm{~m}, \mathrm{D}, 0.75 \mathrm{~m}$, and $\mathrm{E}, 1.0 \mathrm{~m}$ for the 2013 calibration period. 
$\boldsymbol{A}$

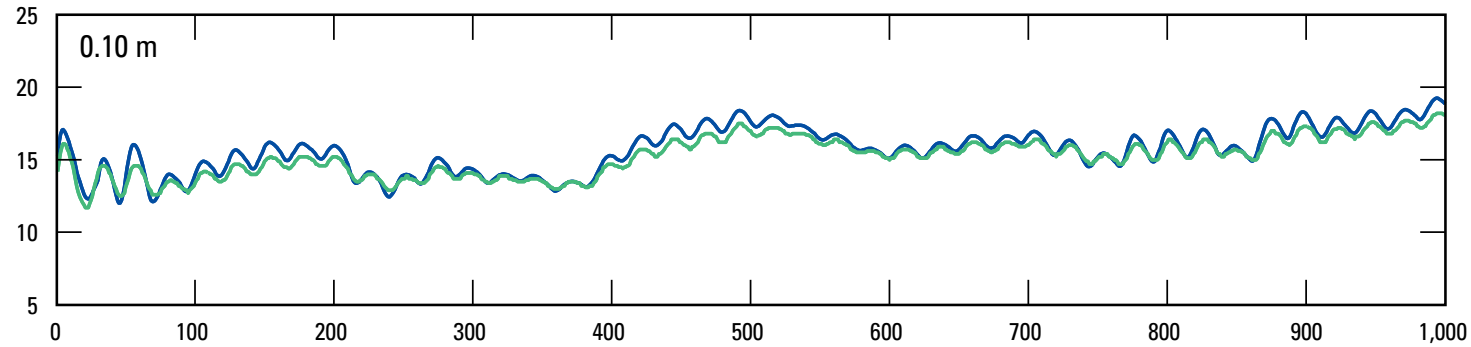

B

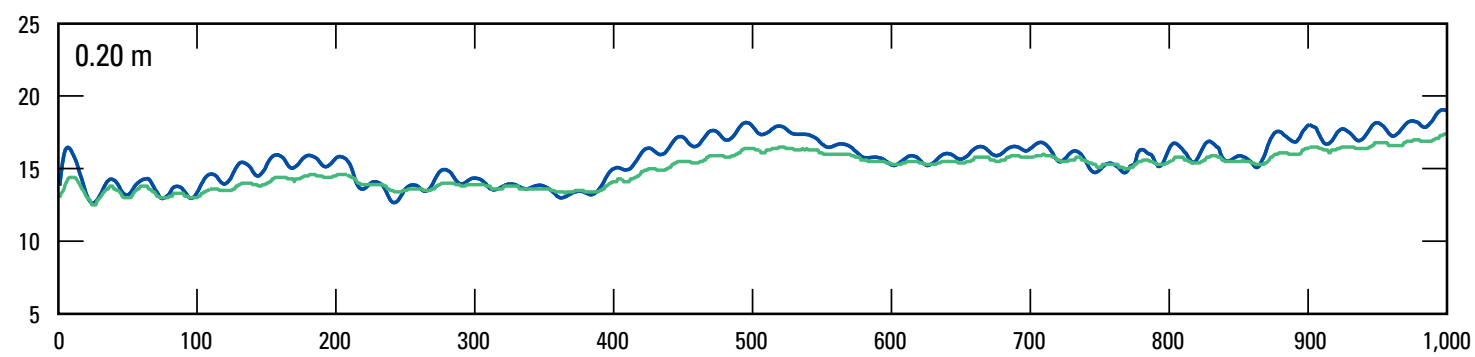

C

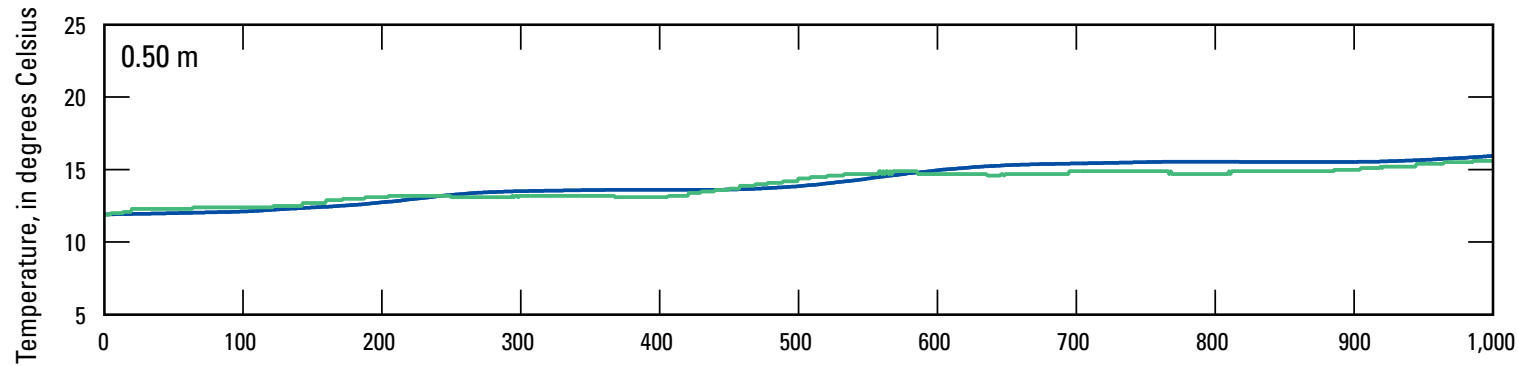

D

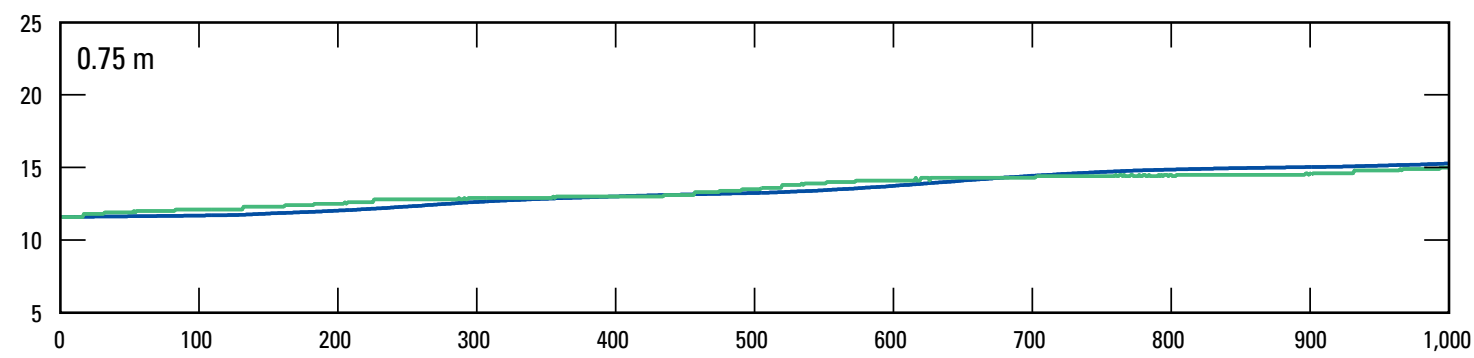

$\boldsymbol{E}$

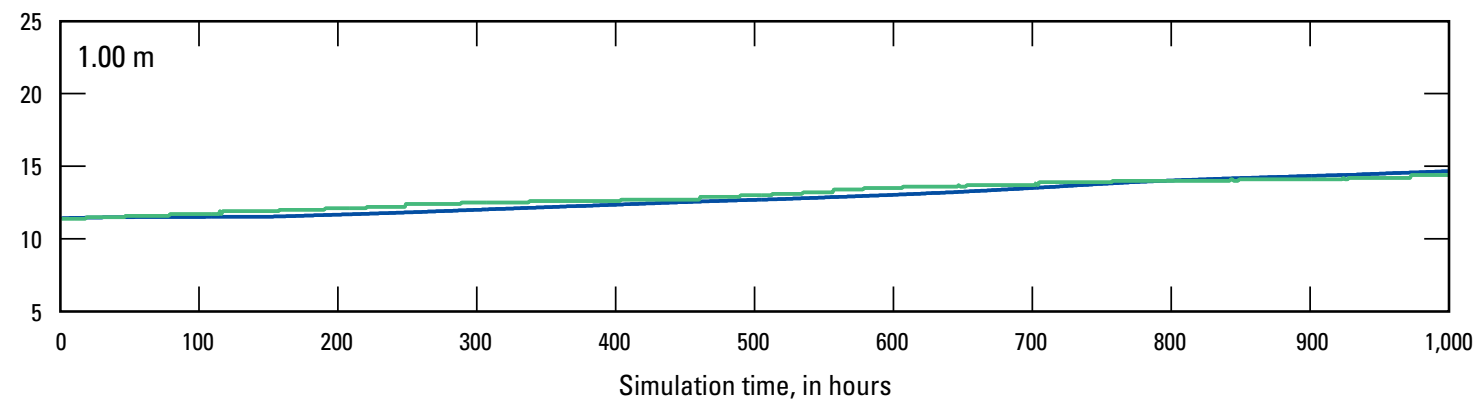

EXPLANATION

Measured

Simulated

Figure 1A-32. Measured and simulated thermographs for canal sediments for T18 at depths of $A, 0.10 \mathrm{~m}, \mathrm{~B}, 0.20 \mathrm{~m}, \mathrm{C}, 0.50 \mathrm{~m}, \mathrm{D}, 0.75 \mathrm{~m}$, and $\mathrm{E}, 1.0 \mathrm{~m}$ for the 2013 calibration period. 

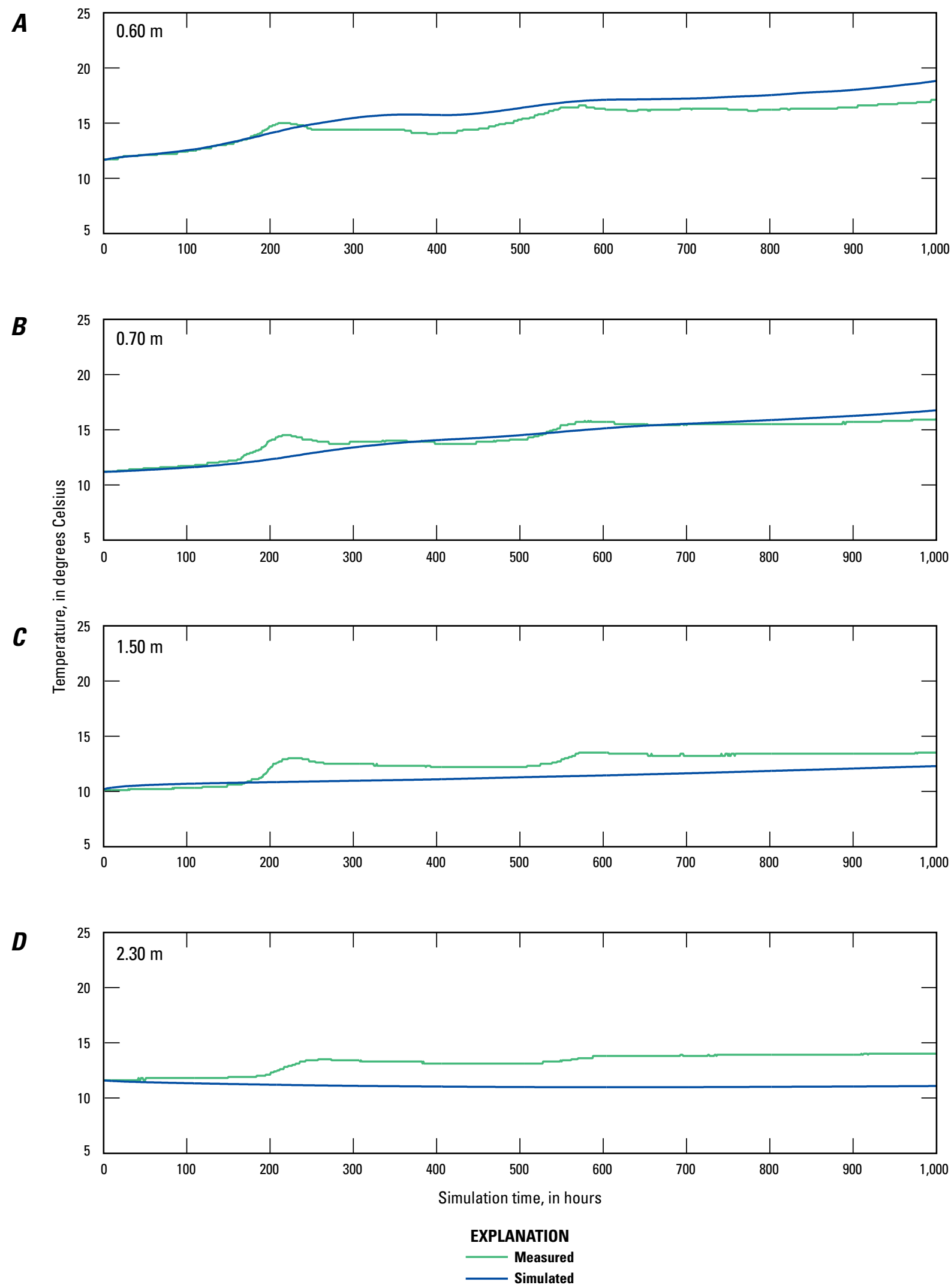

Figure 1A-33. Measured and simulated thermographs for Bank Piezometer 1 (BP1) at depths of $A, 0.60 \mathrm{~m}, B, 0.70 \mathrm{~m}, \mathrm{C}, 1.50 \mathrm{~m}$, and D, $2.30 \mathrm{~m}$ for the 2013 calibration period. 

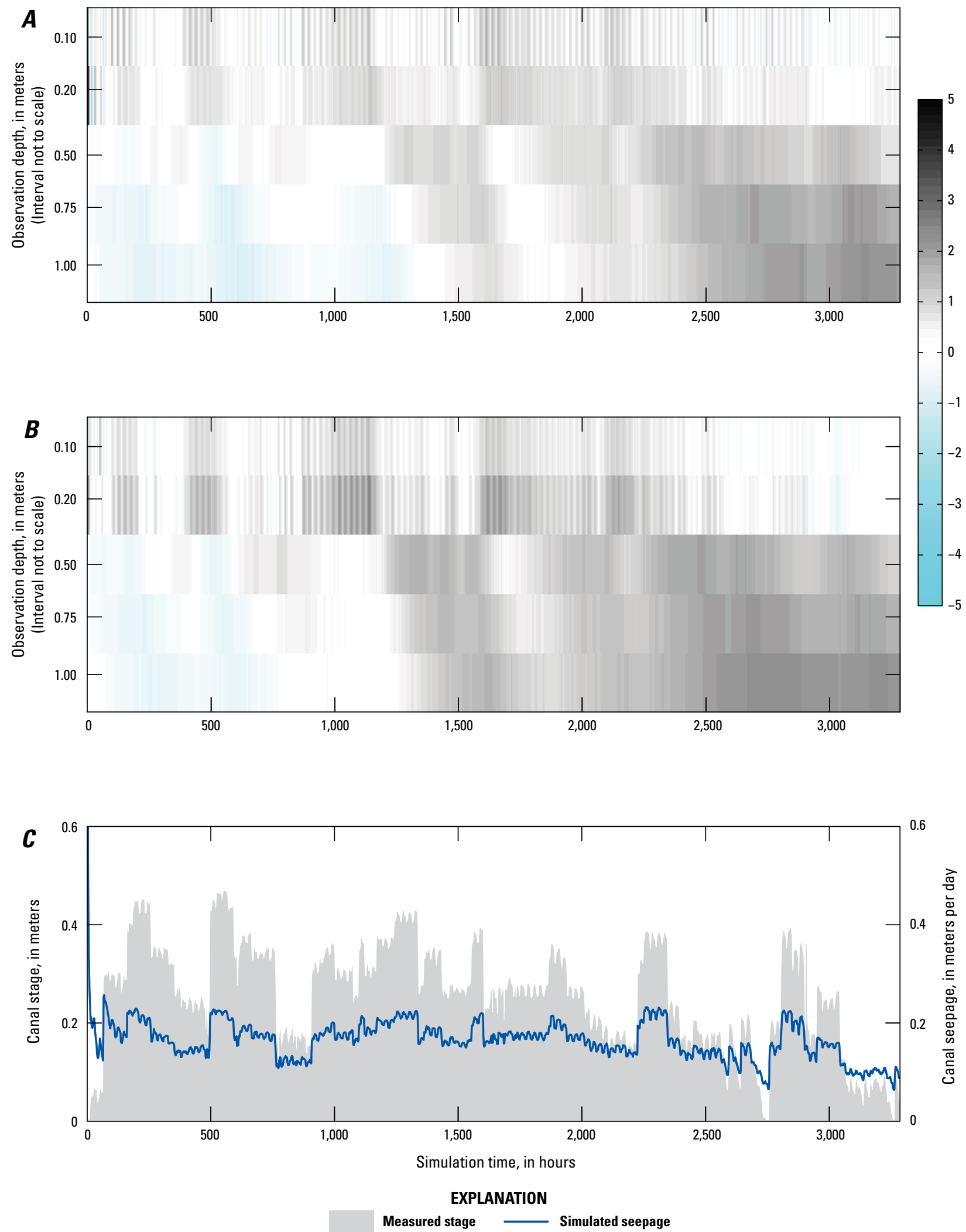

Figure 1A-34. Temperature residual for each depth below the canal at location $A, T 8$ and $B, T 18$, and $C$, measured stage and simulated seepage for the 2013 prediction period. 


\section{Appendix 1A Temperature and Model Results for Saroni Canal 2.1, Smith Valley, Nevada}

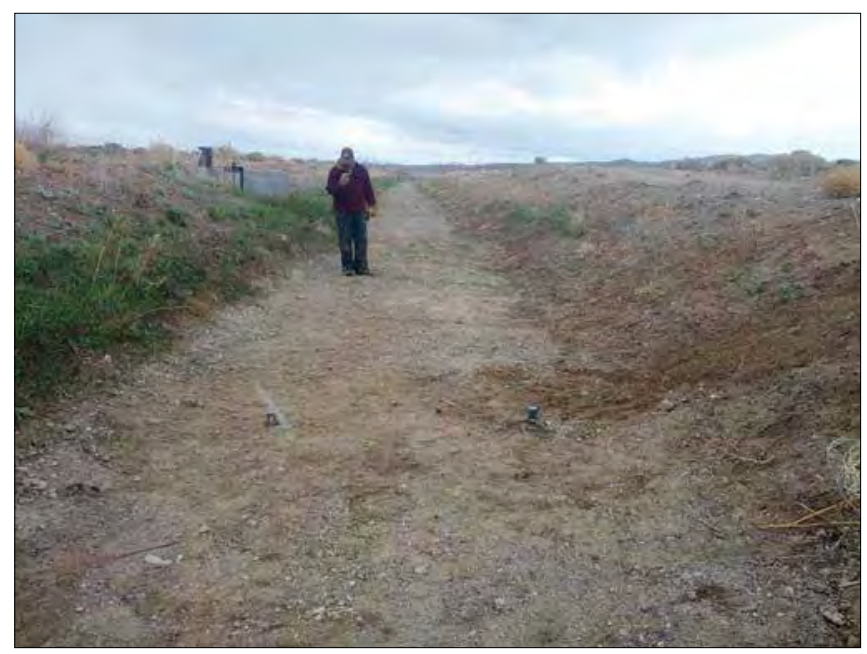

Figure 1A-35. Photograph of SARONI CANAL 2.1 site, Wellington, Nevada. Photograph taken by David W. Smith, U.S. Geological Survey, looking downstream on 4/9/2013.

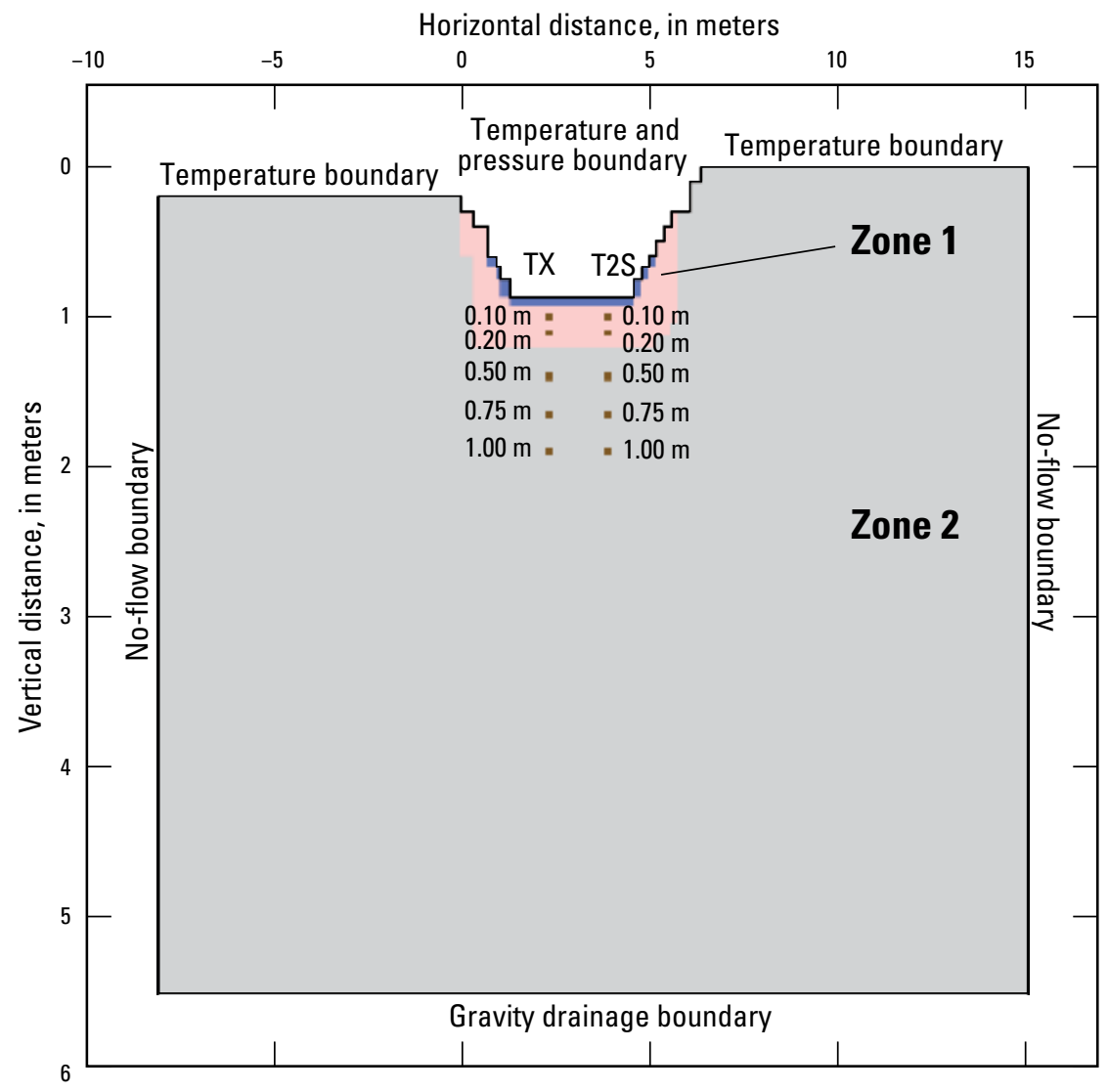

Figure 1A-36. Schematic cross section of two-dimensional VS2DH model of water and heat transport through canal-bed sediments at SARONI CANAL 2.1 site with soil textural zones (Zones 1-2), locations of temperature observations below ground surface within the canal (TX and T2S), and specified vertical and horizontal boundary conditions. 

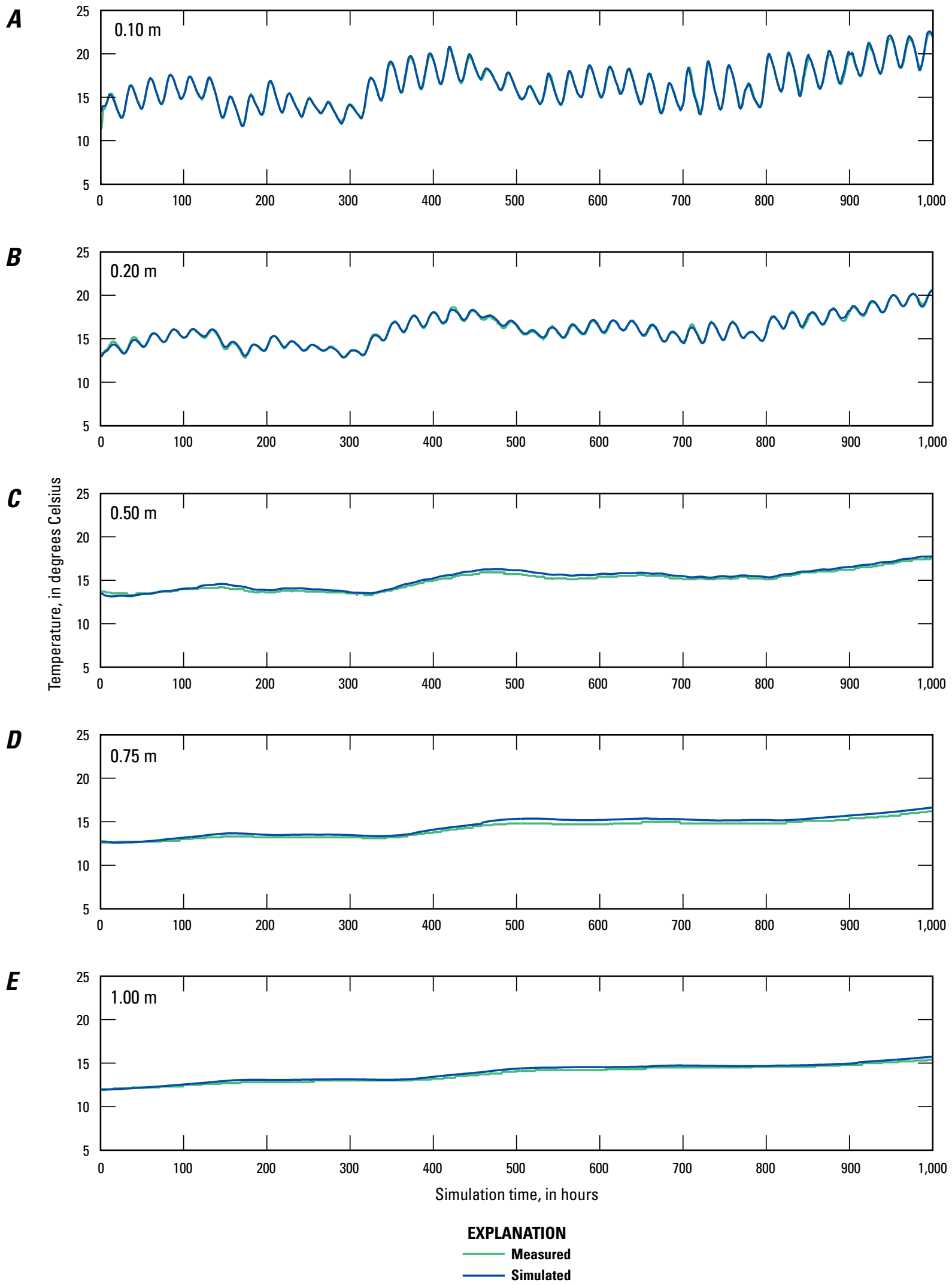

Figure 1A-37. Measured and simulated thermographs for canal sediments for TX at depths of $A, 0.10 \mathrm{~m}, \mathrm{~B}, 0.20 \mathrm{~m}, \mathrm{C}, 0.50 \mathrm{~m}, \mathrm{D}, 0.75 \mathrm{~m}$, and $\mathrm{E}, 1.0 \mathrm{~m}$ for the 2013 calibration period. 

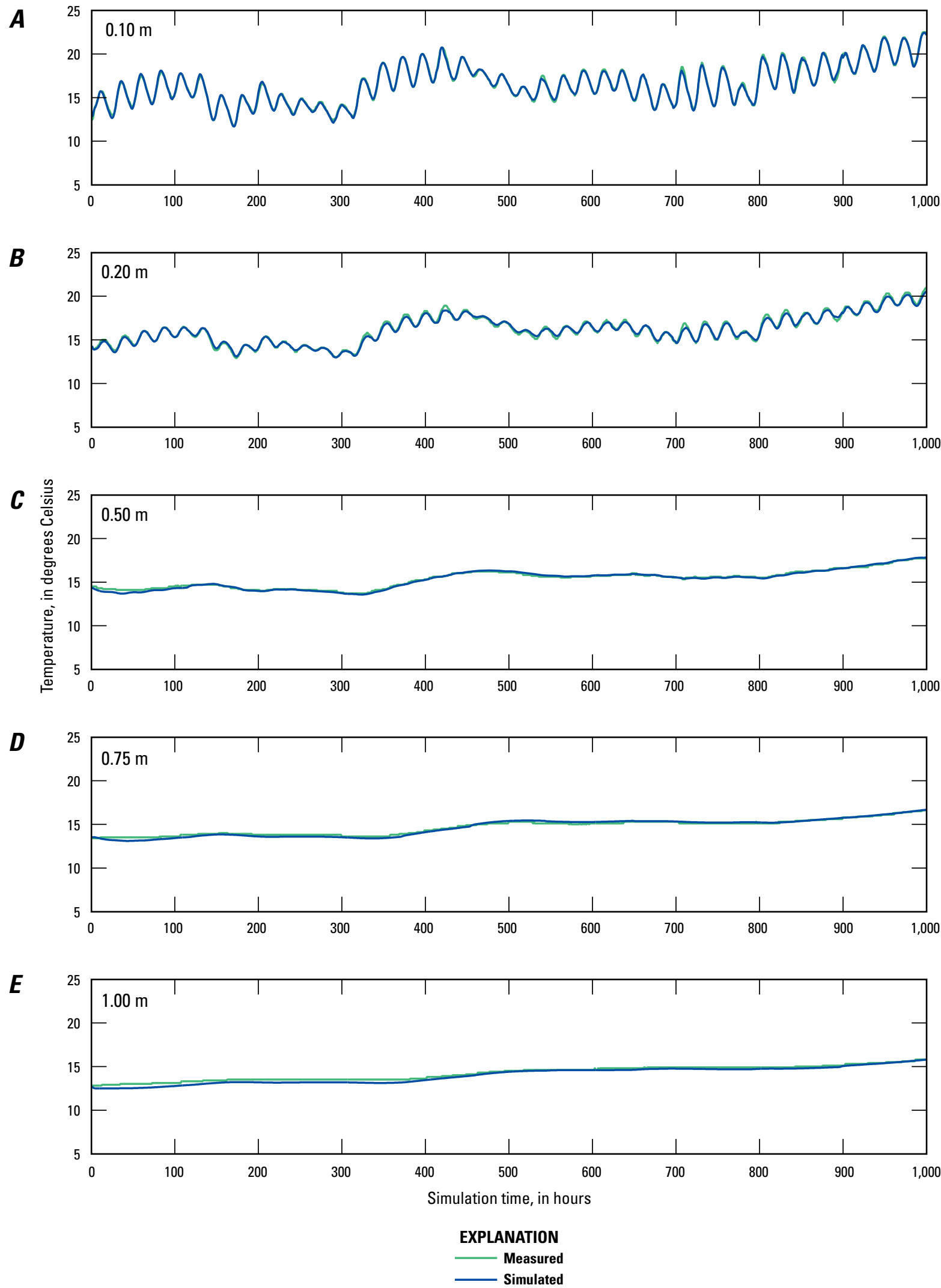

Figure 1A-38. Measured and simulated thermographs for canal sediments for T2S at depths of A, 0.10 m, B, $0.20 \mathrm{~m}, \mathrm{C}, 0.50 \mathrm{~m}, \mathrm{D}, 0.75 \mathrm{~m}$, and $\mathrm{E}, 1.0 \mathrm{~m}$ for the 2013 calibration period. 

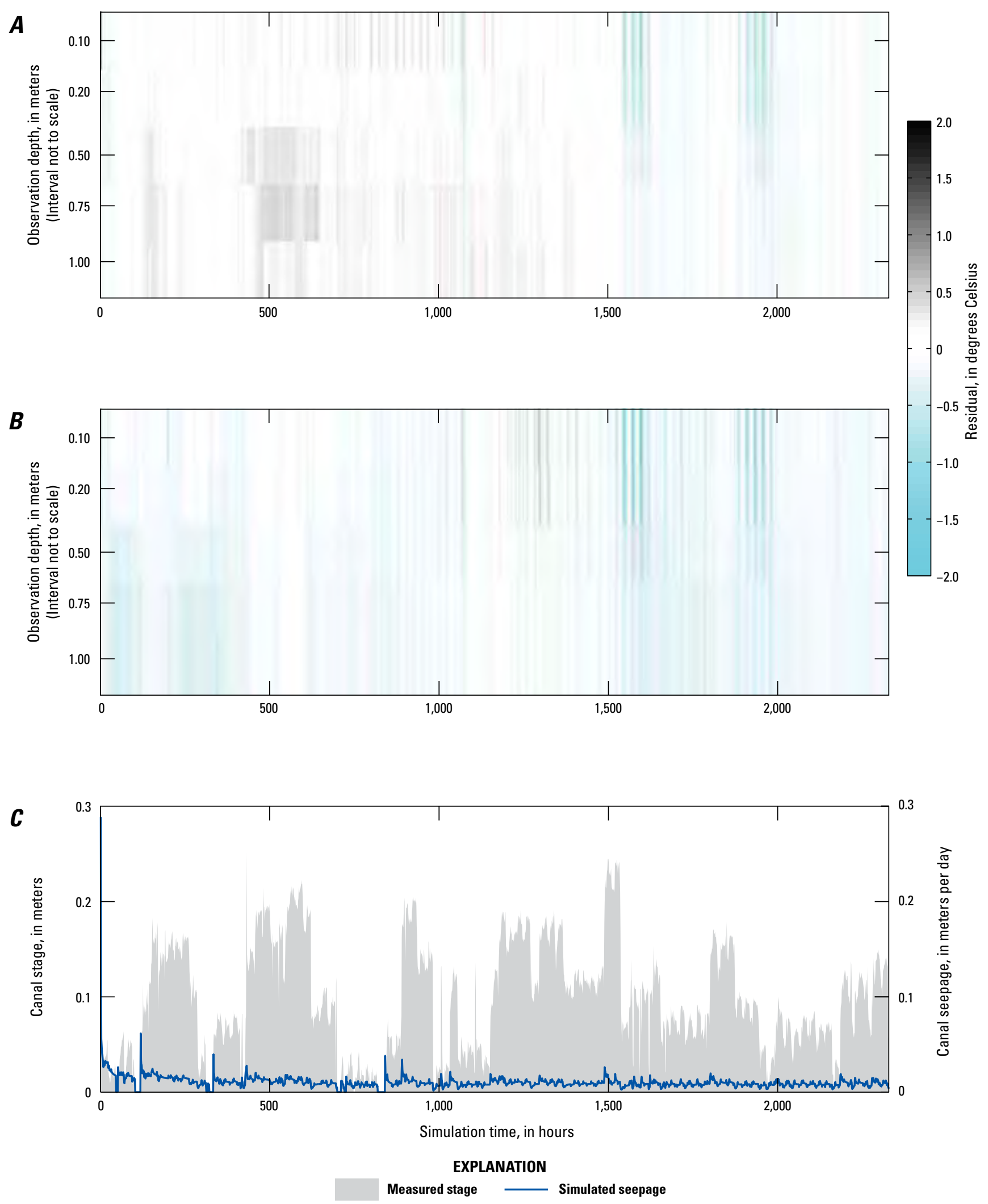

Figure 1A-39. Temperature residual for each depth below the canal at location $A, T X$ and $B, T 2 S$, and $C$, measured stage and simulated seepage for the 2013 prediction period. 


\section{Appendix 1A Temperature and Model Results for Saroni Canal 2.2, Smith Valley, Nevada}

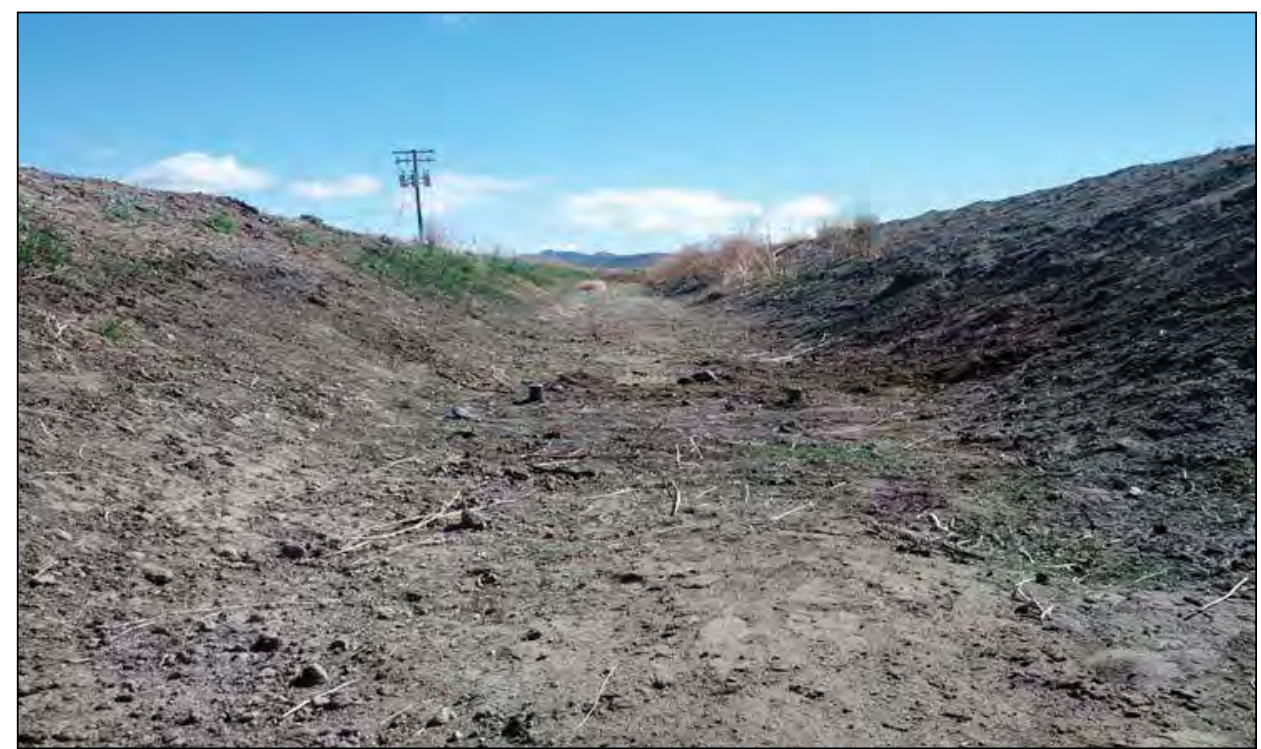

Figure 1A-40. Photograph of SARONI CANAL 2.2 site, Wellington, Nevada. Photograph taken by David W. Smith, U.S. Geological Survey, looking downstream on 4/9/2013.

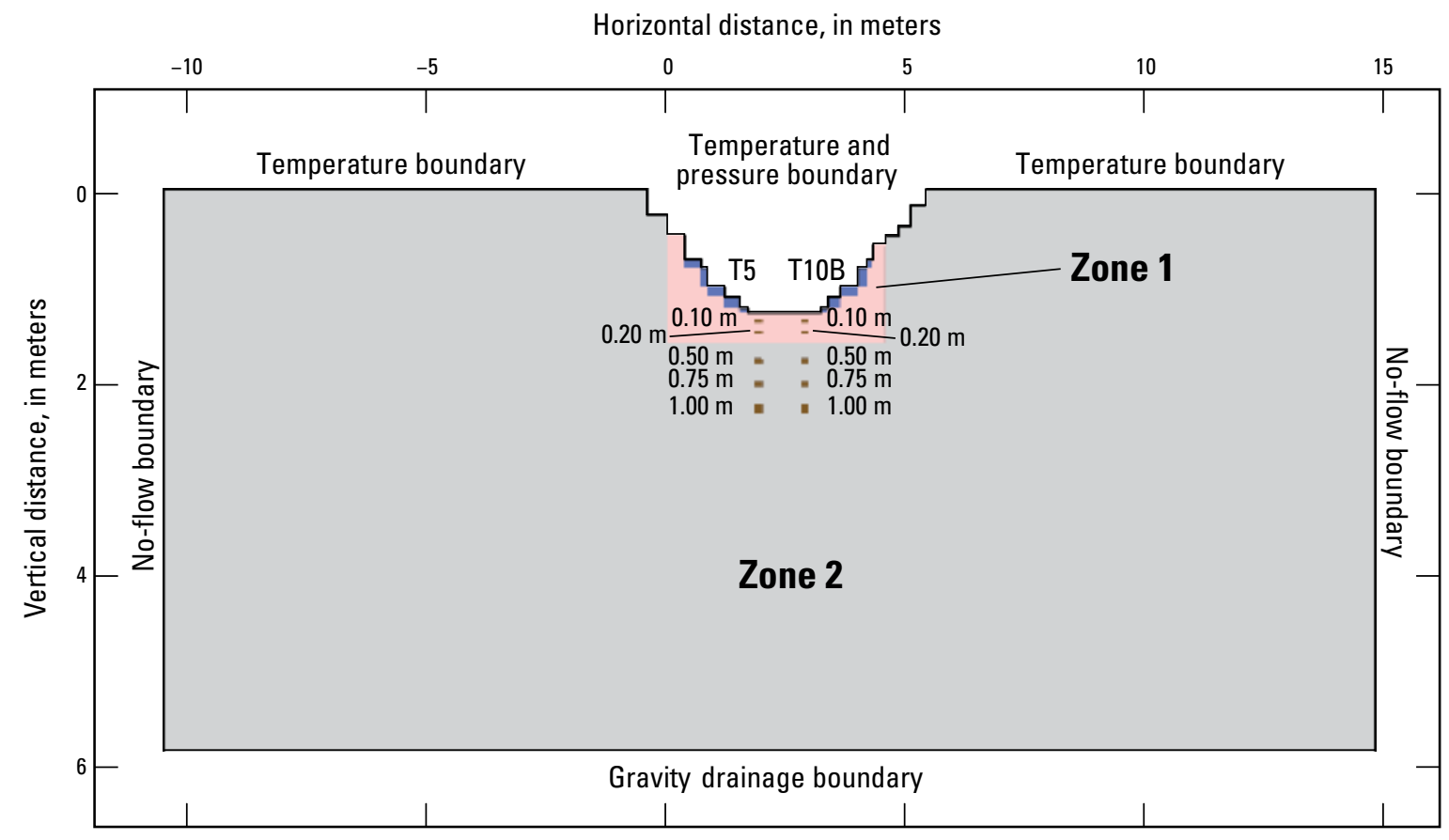

Figure 1A-41. Schematic cross section of two-dimensional VS2DH model of water and heat transport through canal-bed sediments at SARONI CANAL 2.2 site with soil textural zones (Zones 1-2), locations of temperature observations below ground surface within the canal (T5 and $\mathrm{T} 10 \mathrm{~B})$, and specified vertical and horizontal boundary conditions. 

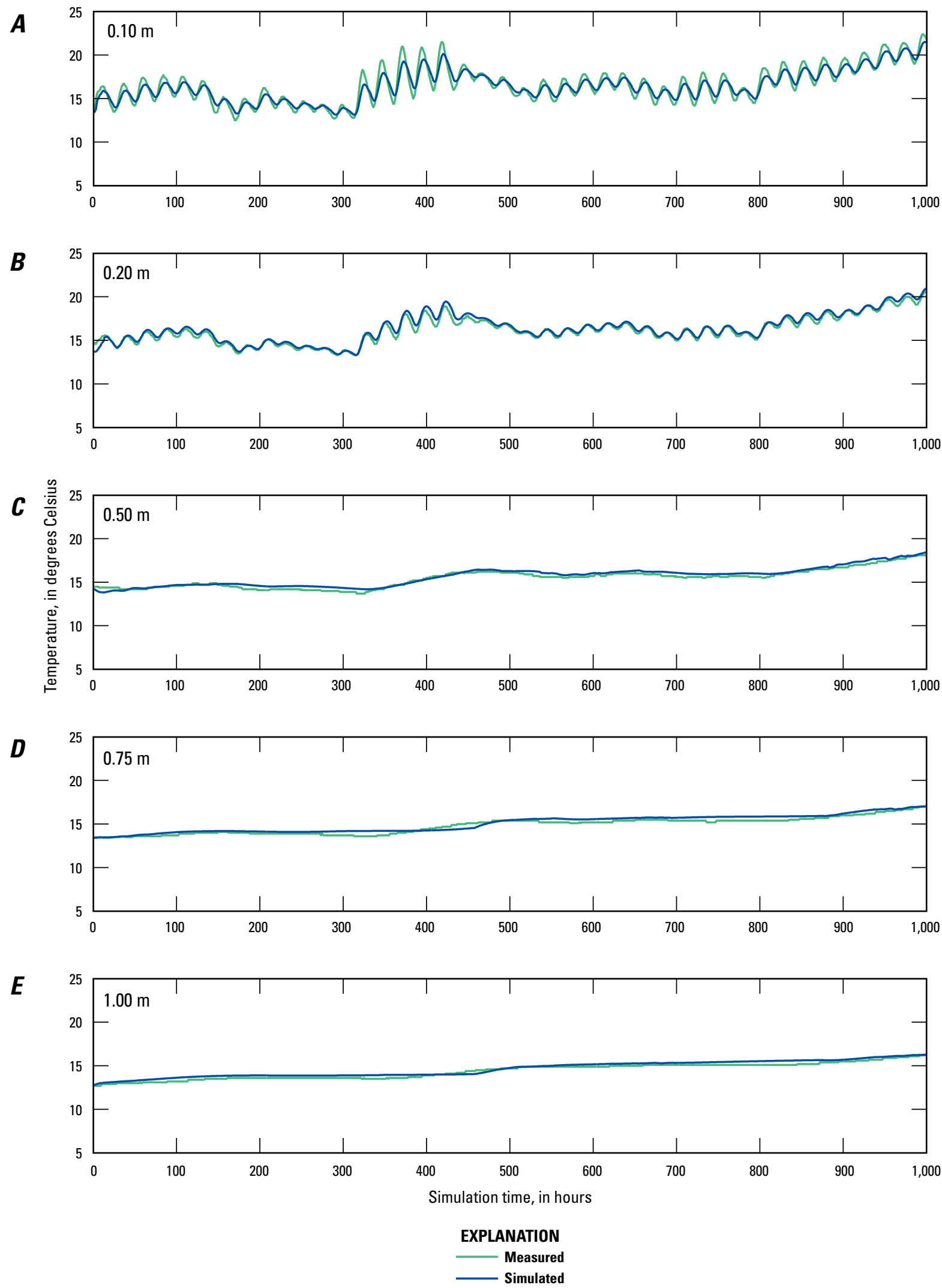

Figure 1A-42. Measured and simulated thermographs for canal sediments for T5 at depths of $A, 0.10 \mathrm{~m}, \mathrm{~B}, 0.20 \mathrm{~m}, \mathrm{C}, 0.50 \mathrm{~m}, \mathrm{D}, 0.75 \mathrm{~m}$, and $E, 1.0 \mathrm{~m}$ for the 2013 calibration period. 

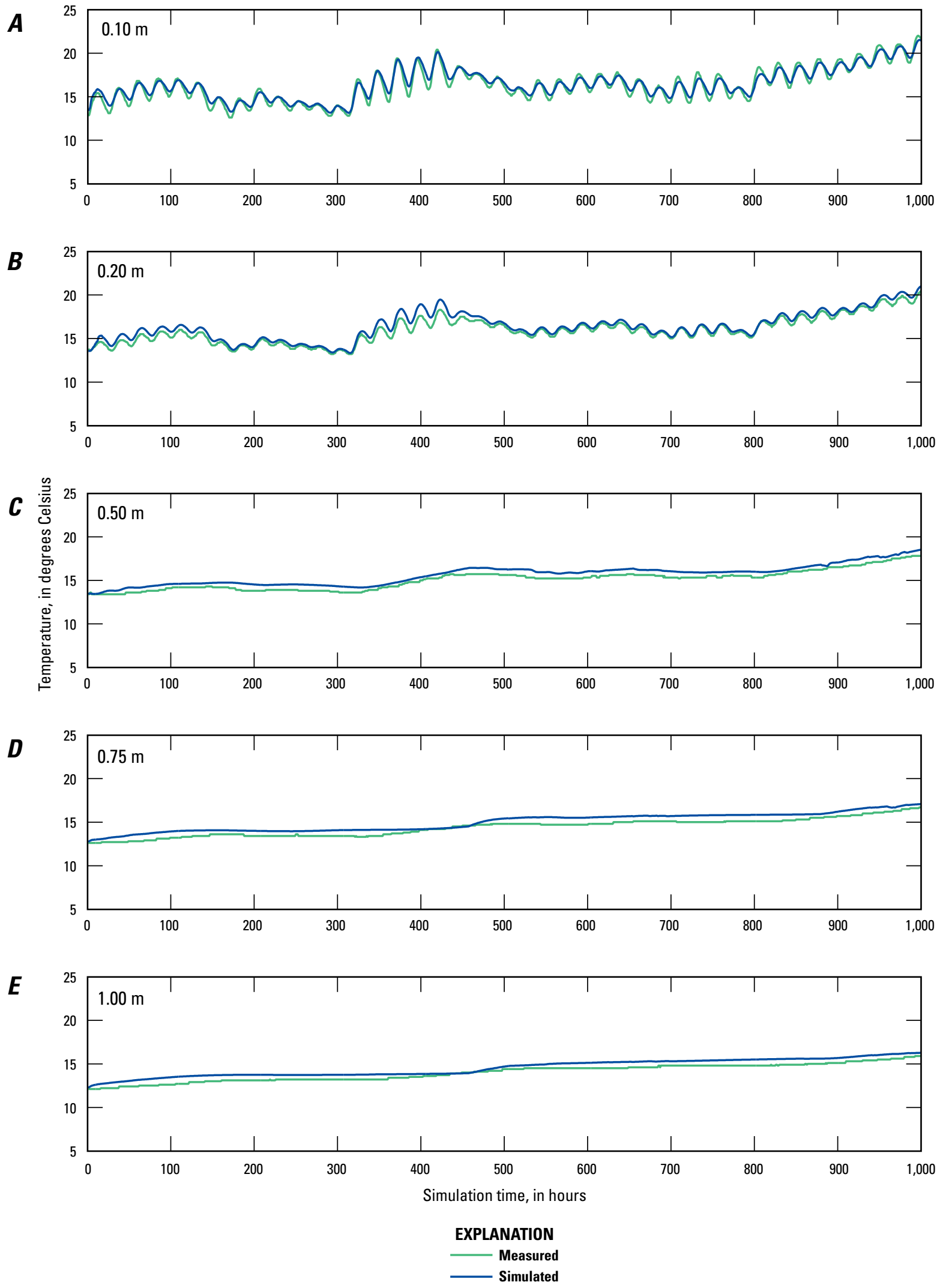

Figure 1A-43. Measured and simulated thermographs for canal sediments for T10B at depths of $A, 0.10 \mathrm{~m}, B, 0.20 \mathrm{~m}, \mathrm{C}, 0.50 \mathrm{~m}$, $\mathrm{D}, 0.75 \mathrm{~m}$, and $\mathrm{E}, 1.0 \mathrm{~m}$ for the 2013 calibration period. 

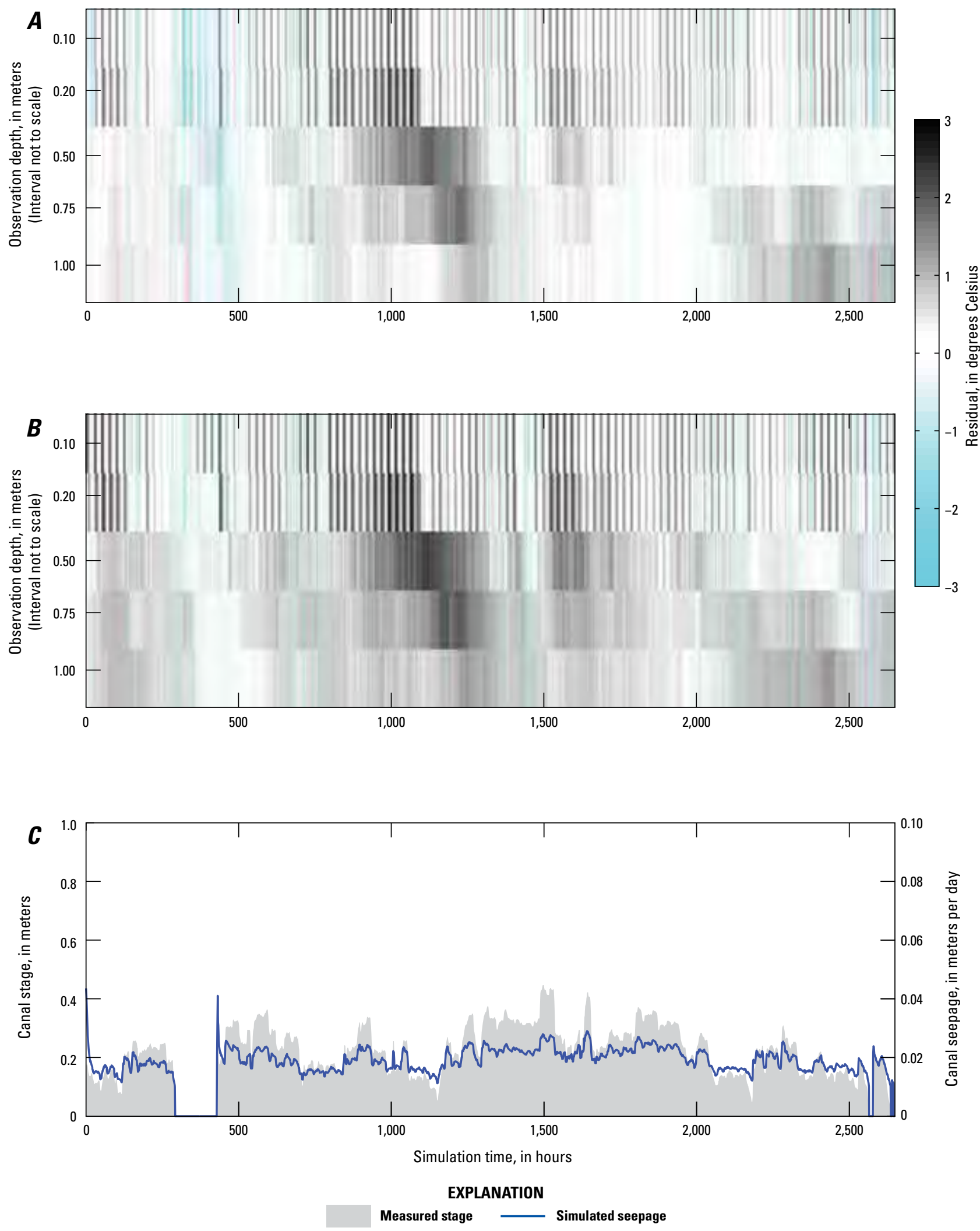

Figure 1A-44. Temperature residual for each depth below the canal at location $A$, $T 5$ and $B, T 10 B$, and $C$, measured stage and simulated seepage for the 2013 prediction period. 


\section{Appendix 1A Temperature and Model Results for Saroni Canal 3, Smith Valley, Nevada}

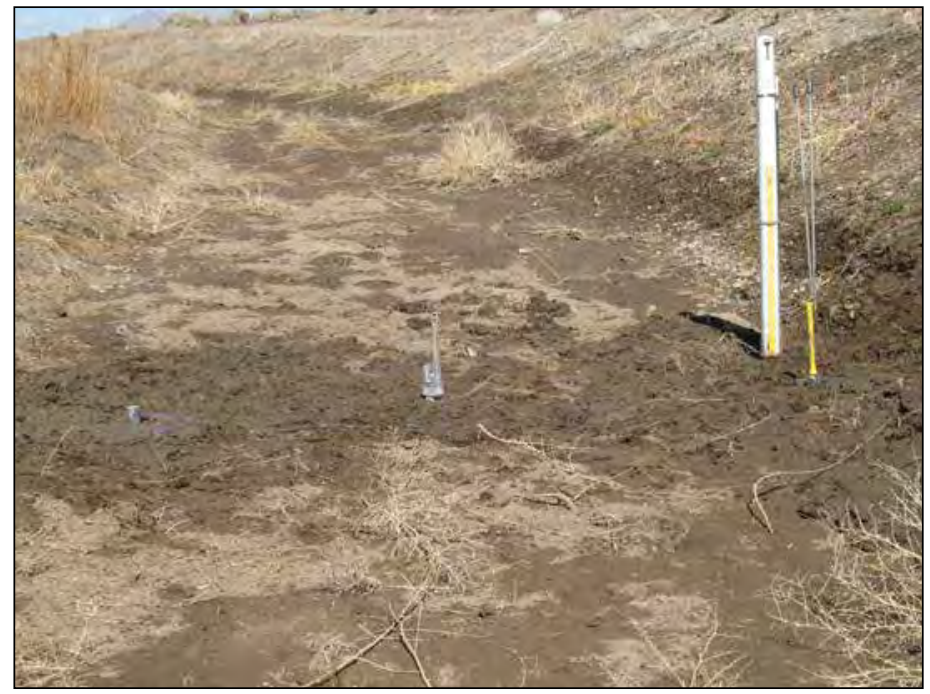

Figure 1A-45. Photograph of SARONI CANAL 3 site, Wellington, Nevada. Photograph taken by David W. Smith, U.S. Geological Survey, looking downstream on 3/4/2013.

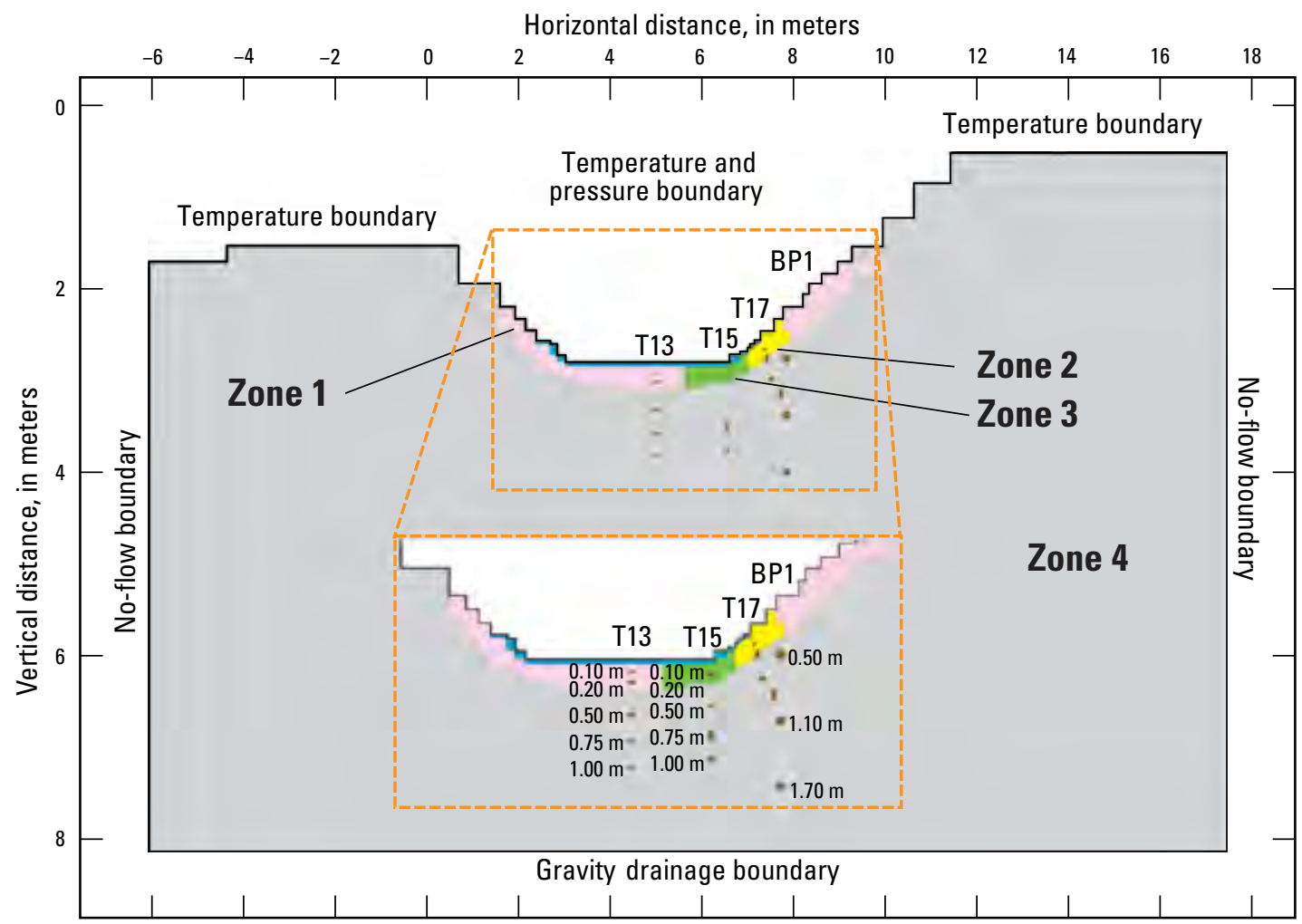

Figure 1A-46. Schematic cross section of two-dimensional VS2DH model of water and heat transport through canal-bed sediments at SARONI CANAL 3 site with soil textural zones (Zones 1-4), locations of temperature observations below ground surface within the canal $(\mathrm{T} 13, \mathrm{~T} 15$, and $\mathrm{T} 17)$ and along the banks (BP1), and specified vertical and horizontal boundary conditions. 
$\boldsymbol{A}$

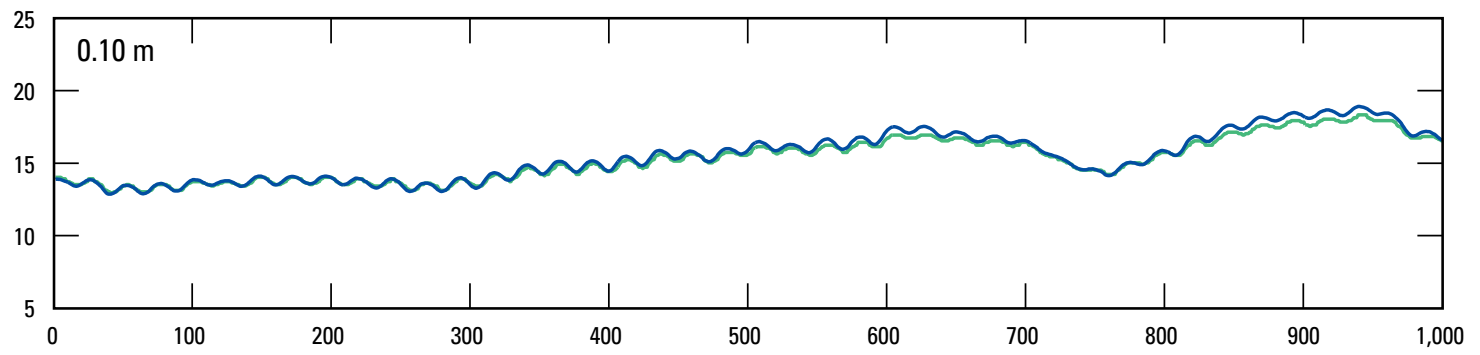

B

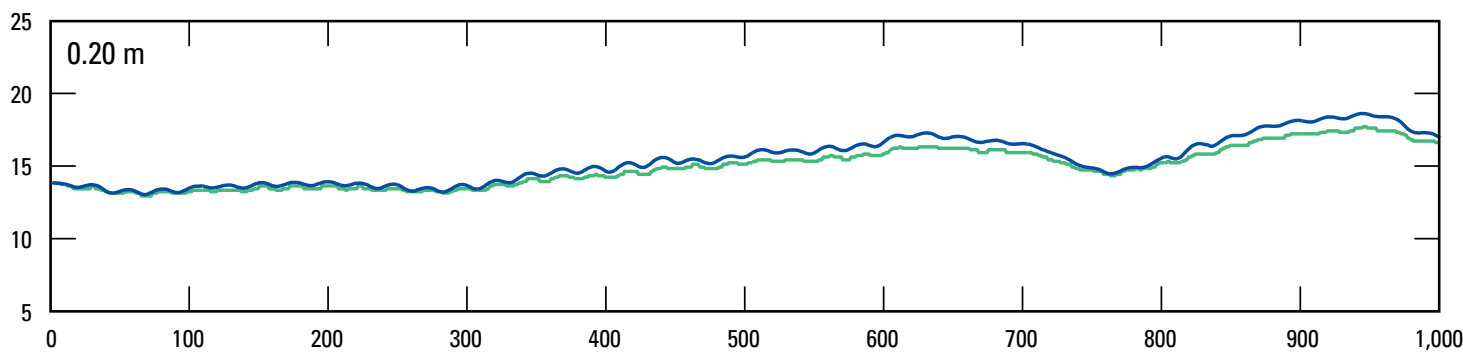

C

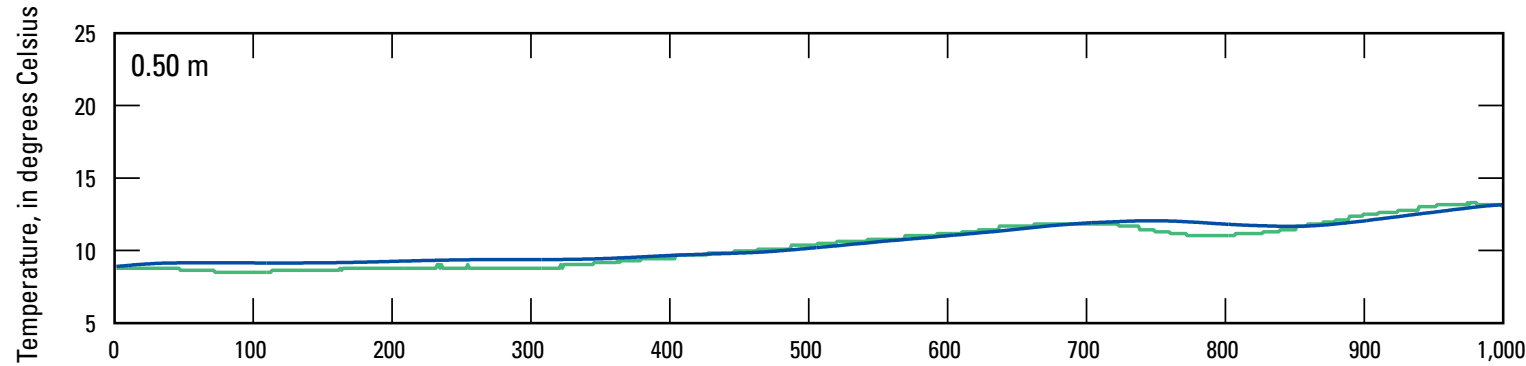

D

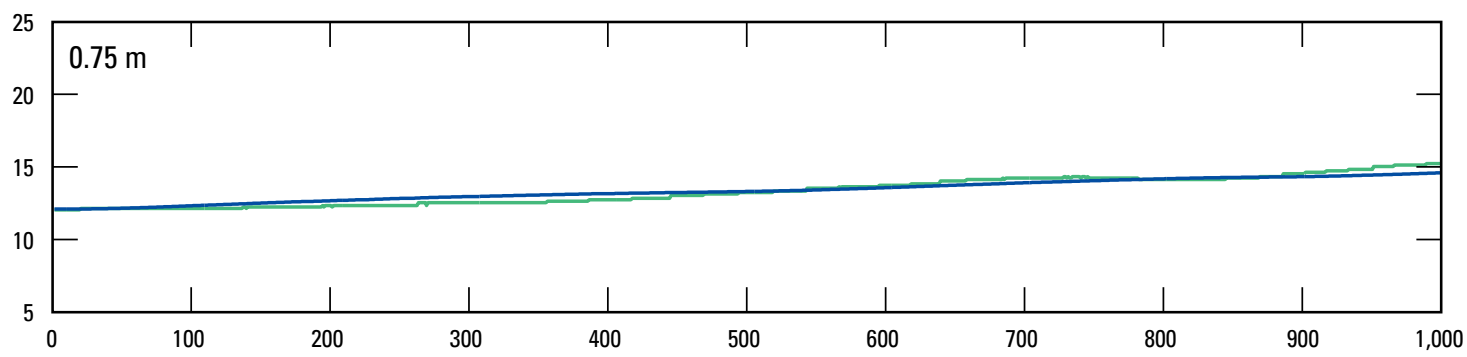

$\boldsymbol{E}$

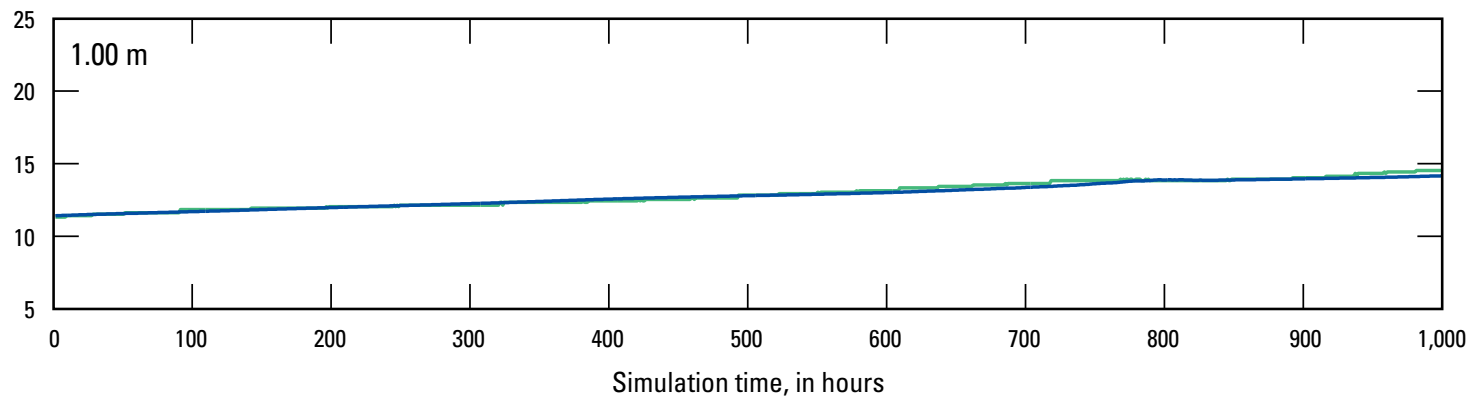

EXPLANATION

Measured

Simulated

Figure 1A-47. Measured and simulated thermographs for canal sediments for T13 at depths of $A, 0.10 \mathrm{~m}, \mathrm{~B}, 0.20 \mathrm{~m}, \mathrm{C}, 0.50 \mathrm{~m}, \mathrm{D}, 0.75 \mathrm{~m}$, and $E, 1.0 \mathrm{~m}$ for the 2012 calibration period. 

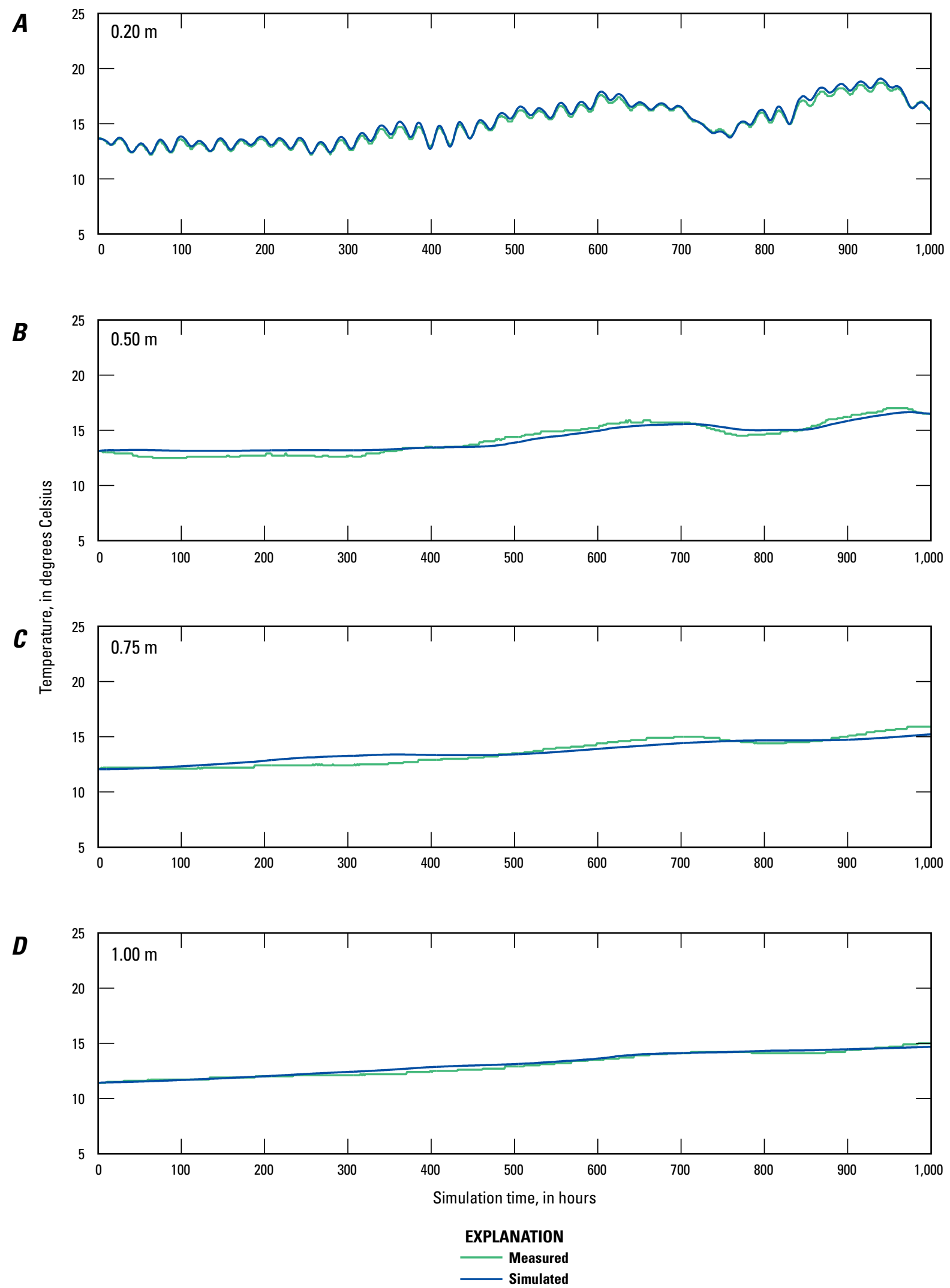

Figure 1A-48. Measured and simulated thermographs for canal sediments for T15 at depths of $A, 0.20 \mathrm{~m}, \mathrm{~B}, 0.50 \mathrm{~m}, \mathrm{C}, 0.75 \mathrm{~m}$, and D, $1.0 \mathrm{~m}$ for the 2012 calibration period. 

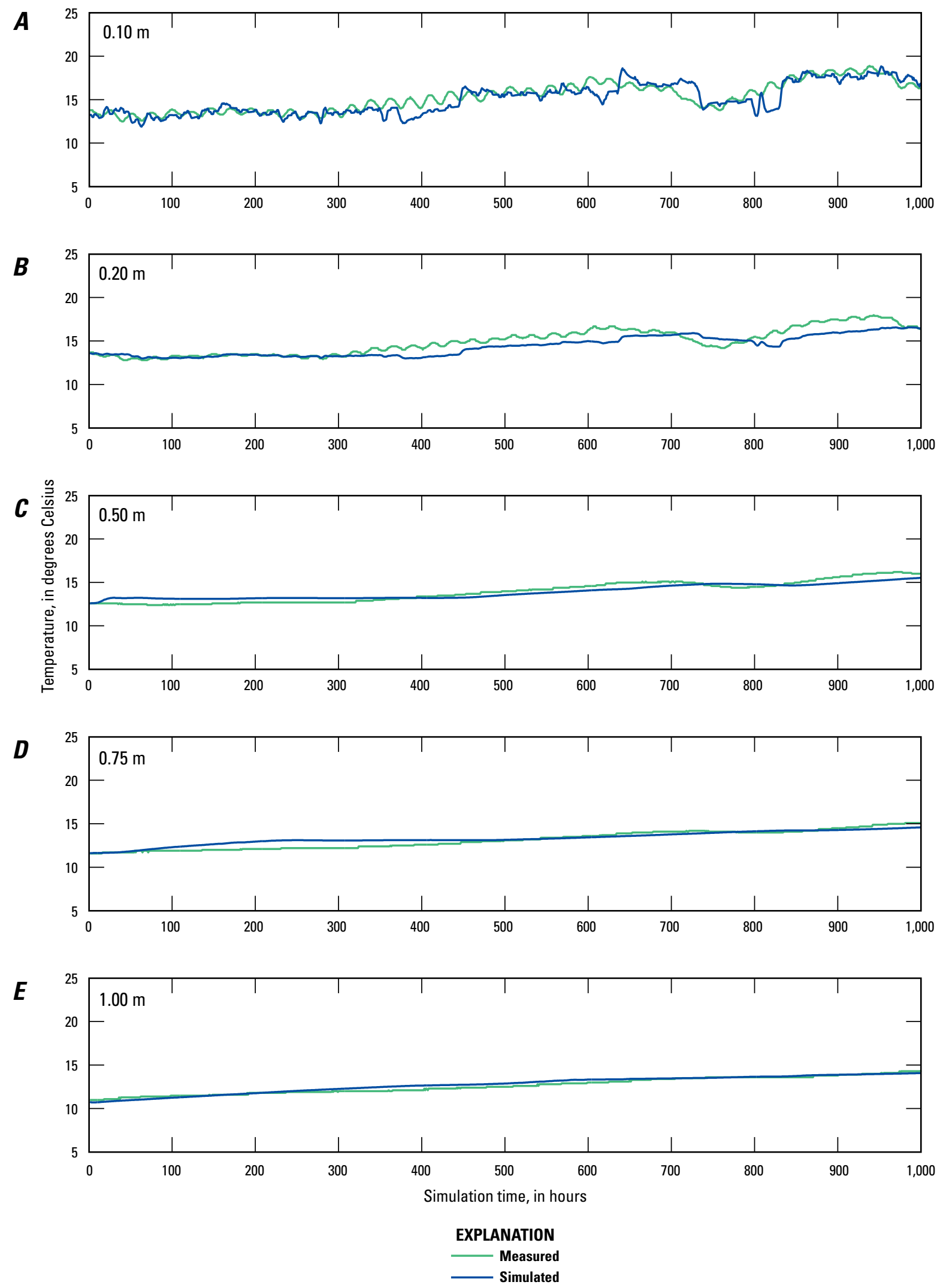

Figure 1A-49. Measured and simulated thermographs for canal sediments for T17 at depths of $A, 0.20 \mathrm{~m}, \mathrm{~B}, 0.50 \mathrm{~m}, \mathrm{C}, 0.75 \mathrm{~m}$, and D, $1.0 \mathrm{~m}$ for the 2012 calibration period. 
74 Quantifying Seepage Using Heat as a Tracer in Selected Irrigation Canals, Walker River Basin, Nevada, 2012 and 2013
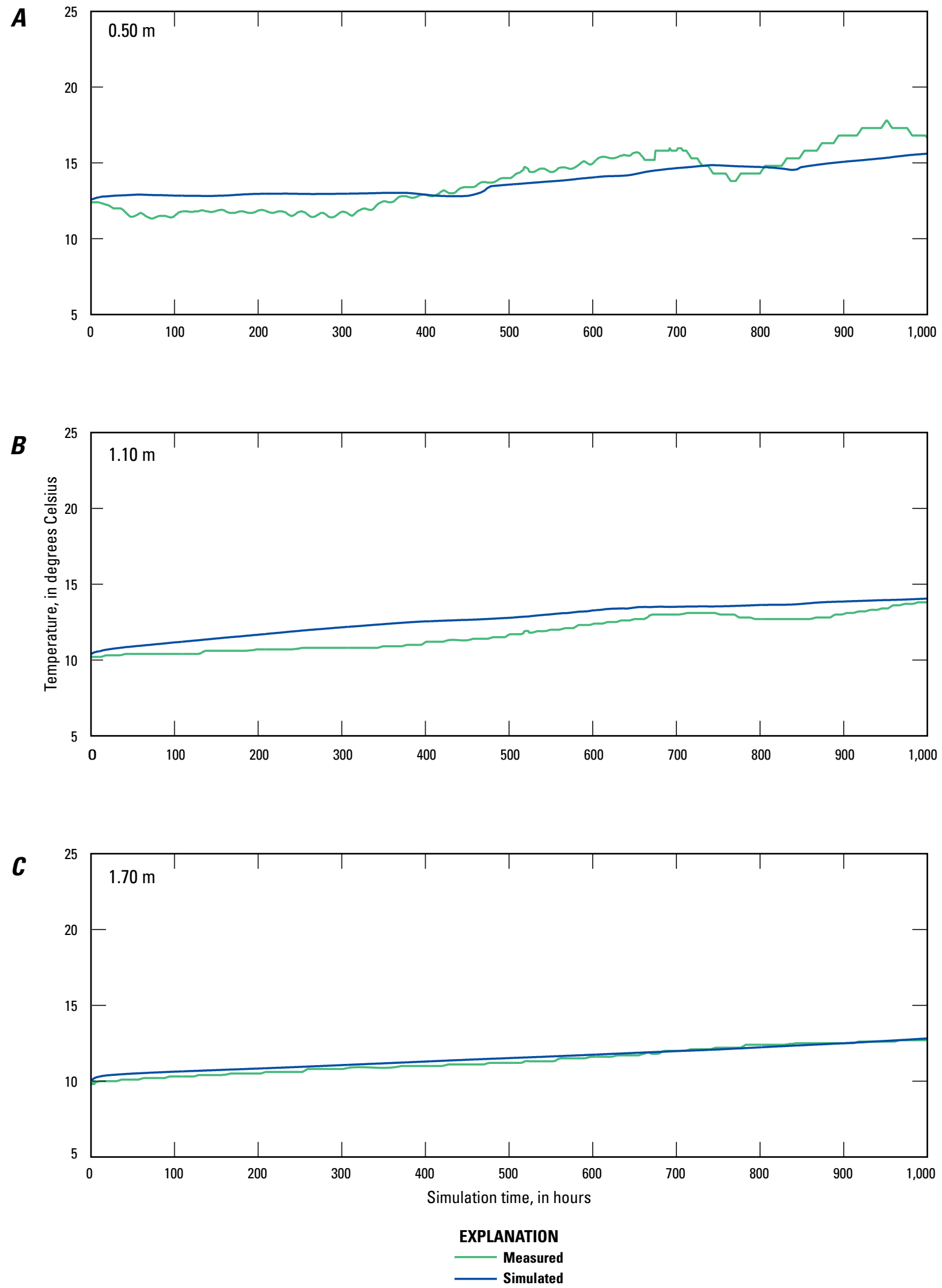

Figure 1A-50. Measured and simulated thermographs for Bank Piezometer 1 (BP1) at depths of $A, 0.50 \mathrm{~m}, \mathrm{~B}, 1.10 \mathrm{~m}$, and $\mathrm{C}, 1.70 \mathrm{~m}$ for the 2012 calibration period. 

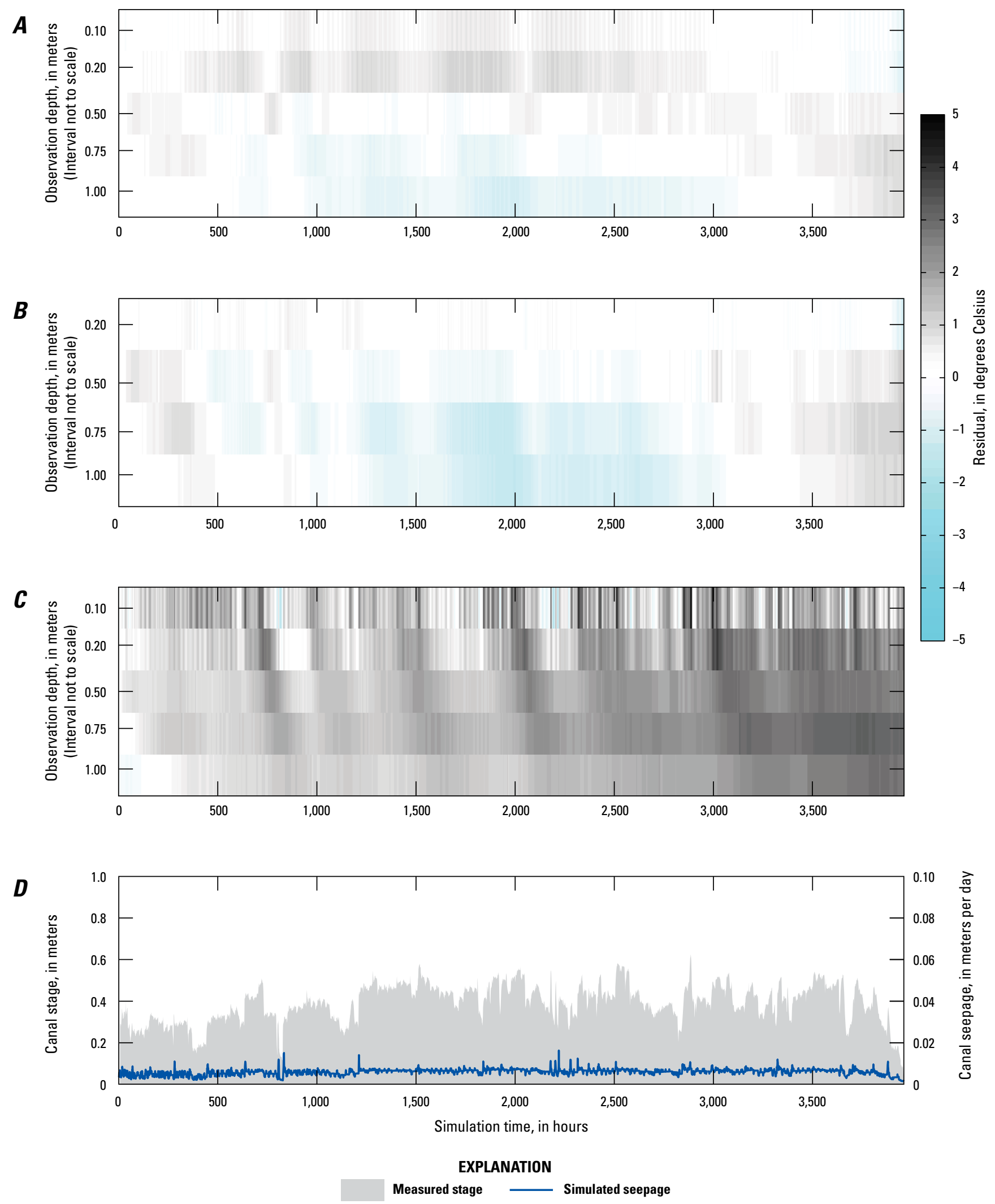

Figure 1A-51. Temperature residual for each depth below the canal at location $A, T 13, B, T 15$, and $C, T 17$, and $D$, measured stage and simulated seepage for the 2012 prediction period. 


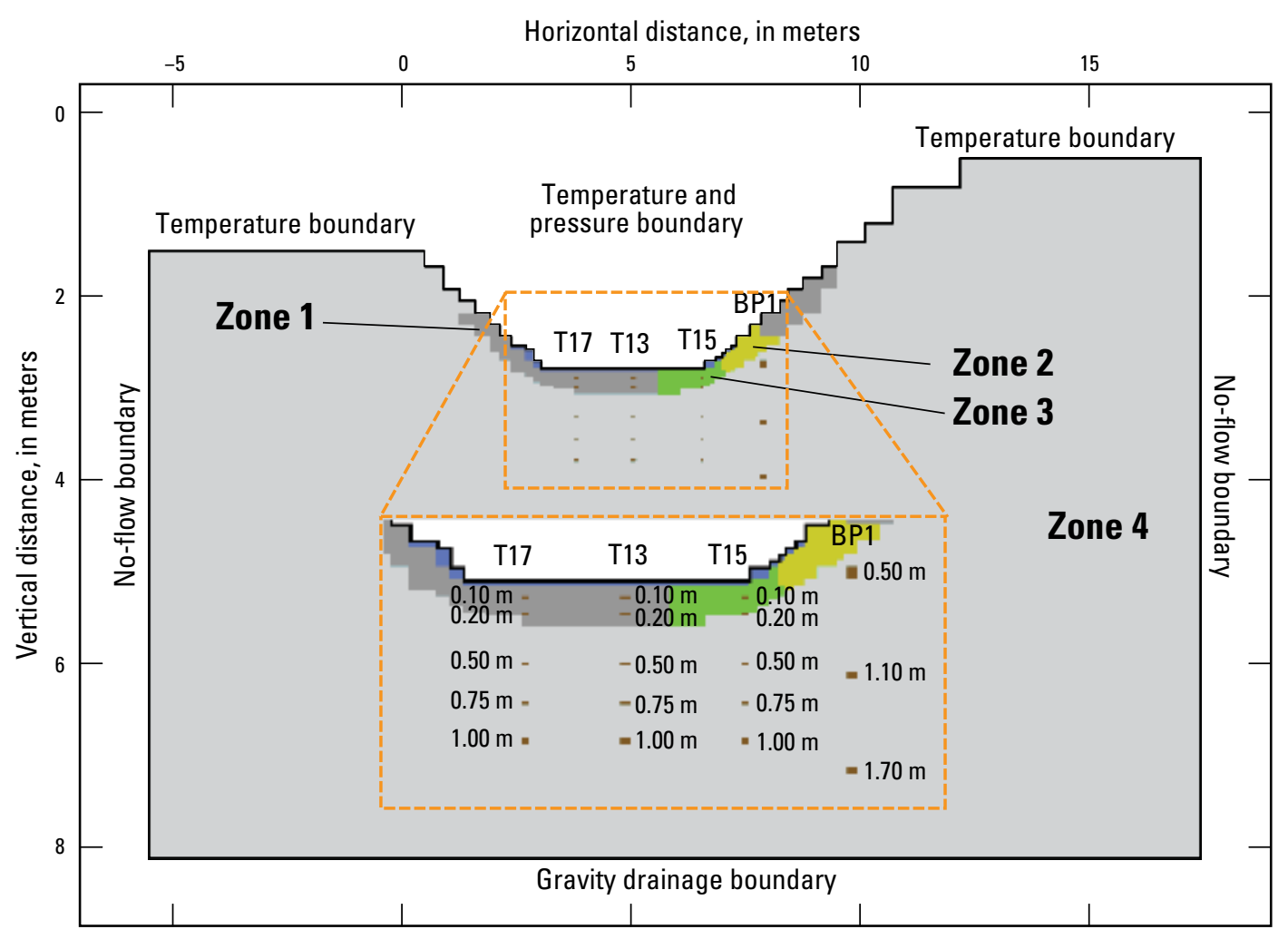

Figure 1A-52. Schematic cross section of two-dimensional VS2DH model of water and heat transport through canal-bed sediments at SARONI CANAL 3 site with soil textural zones (Zones 1-4), locations of temperature observations below ground surface within the canal (T17, T13, and T15) and along the banks (BP1), and specified vertical and horizontal boundary conditions. 

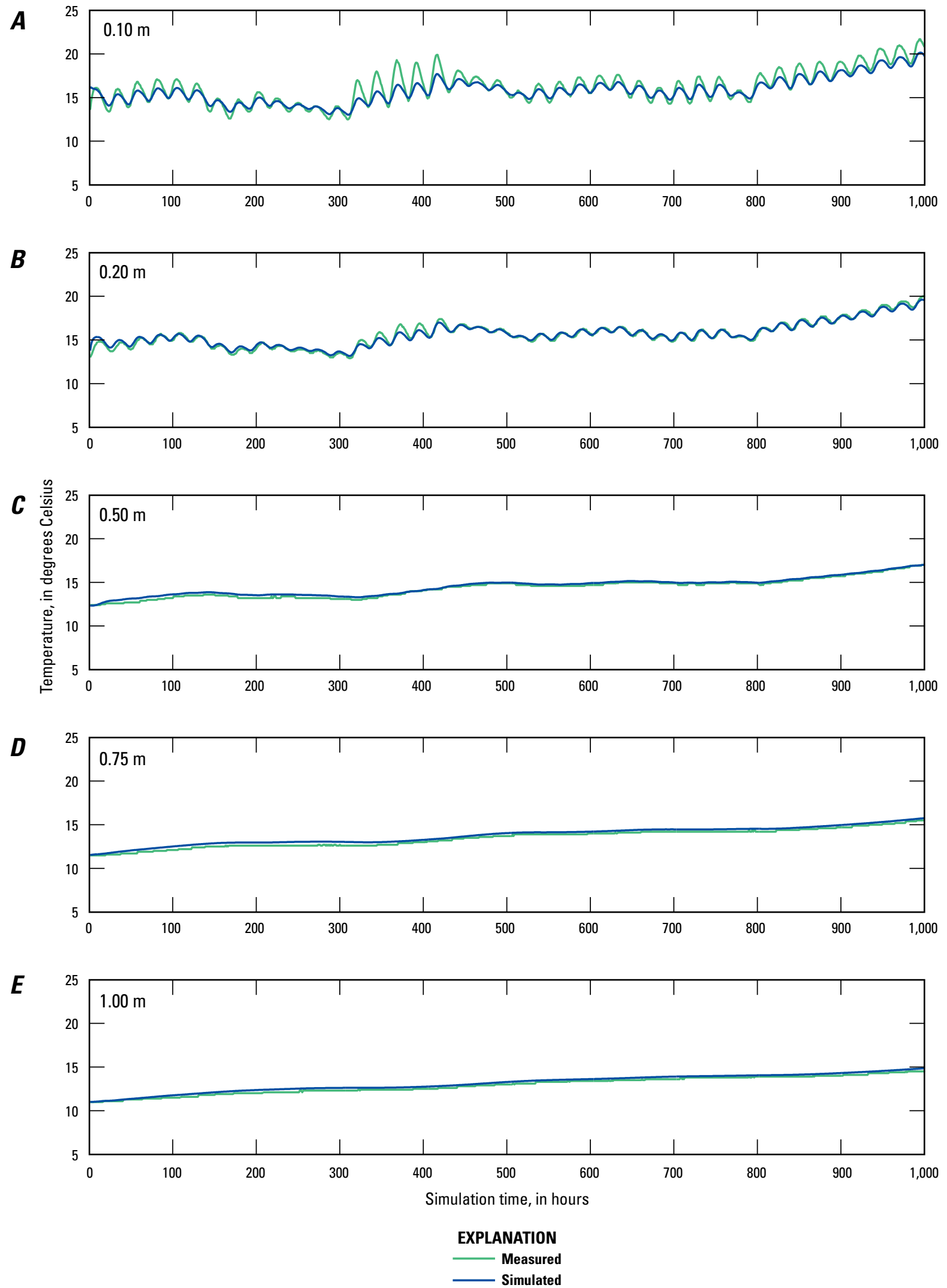

Figure 1A-53. Measured and simulated thermographs for canal sediments for T17 at depths of $A, 0.10 \mathrm{~m}, \mathrm{~B}, 0.20 \mathrm{~m}, \mathrm{C}, 0.50 \mathrm{~m}, \mathrm{D}, 0.75 \mathrm{~m}$, and $\mathrm{E}, 1.0 \mathrm{~m}$ for the 2013 calibration period. 

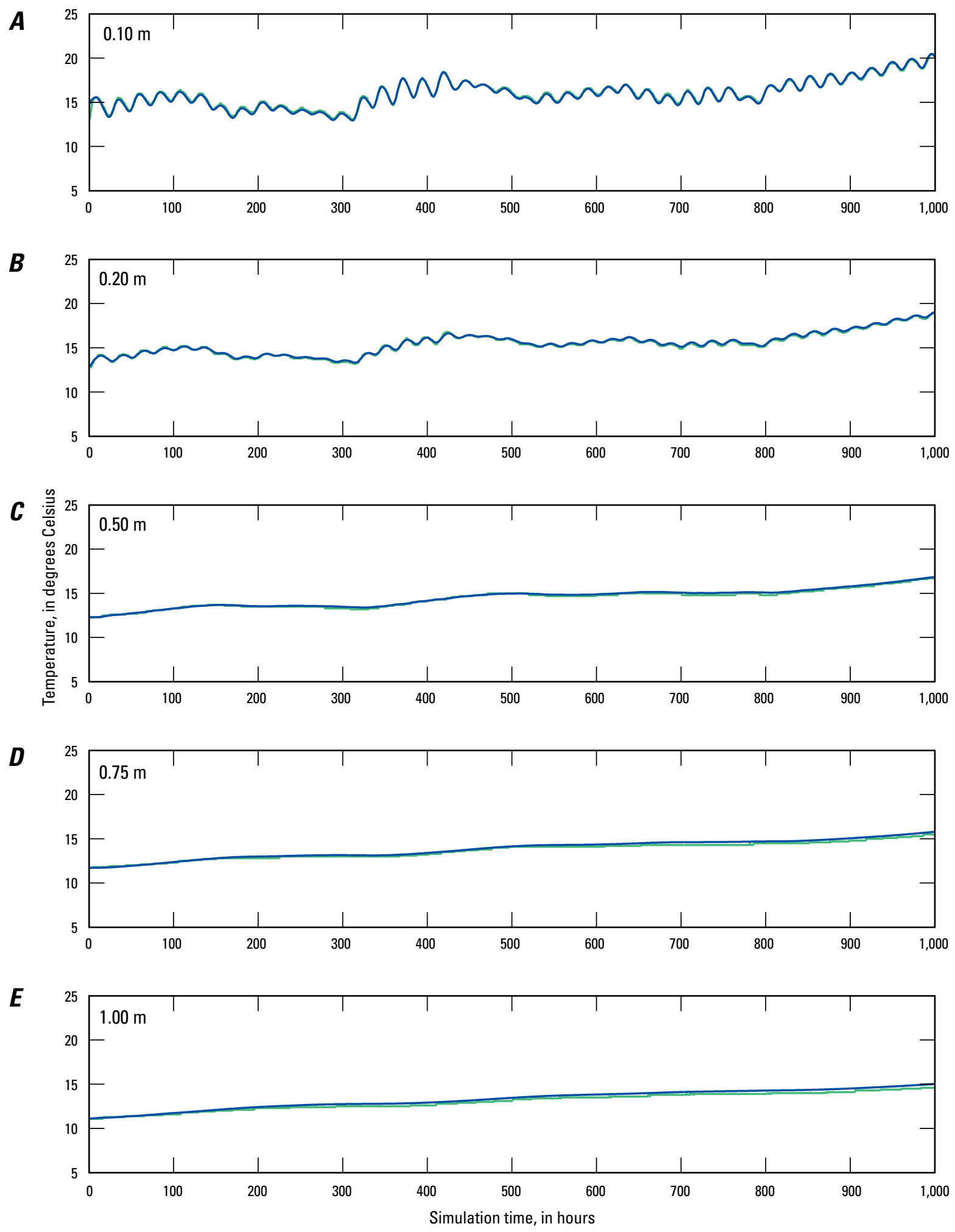

\section{EXPLANATION}

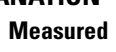

Figure 1A-54. Measured and simulated thermographs for canal sediments for T13 at depths of A, $0.10 \mathrm{~m}, \mathrm{~B}, 0.20 \mathrm{~m}, \mathrm{C}, 0.50 \mathrm{~m}, \mathrm{D}, 0.75 \mathrm{~m}$, and $\mathrm{E}, 1.0 \mathrm{~m}$ for the 2013 calibration period. 

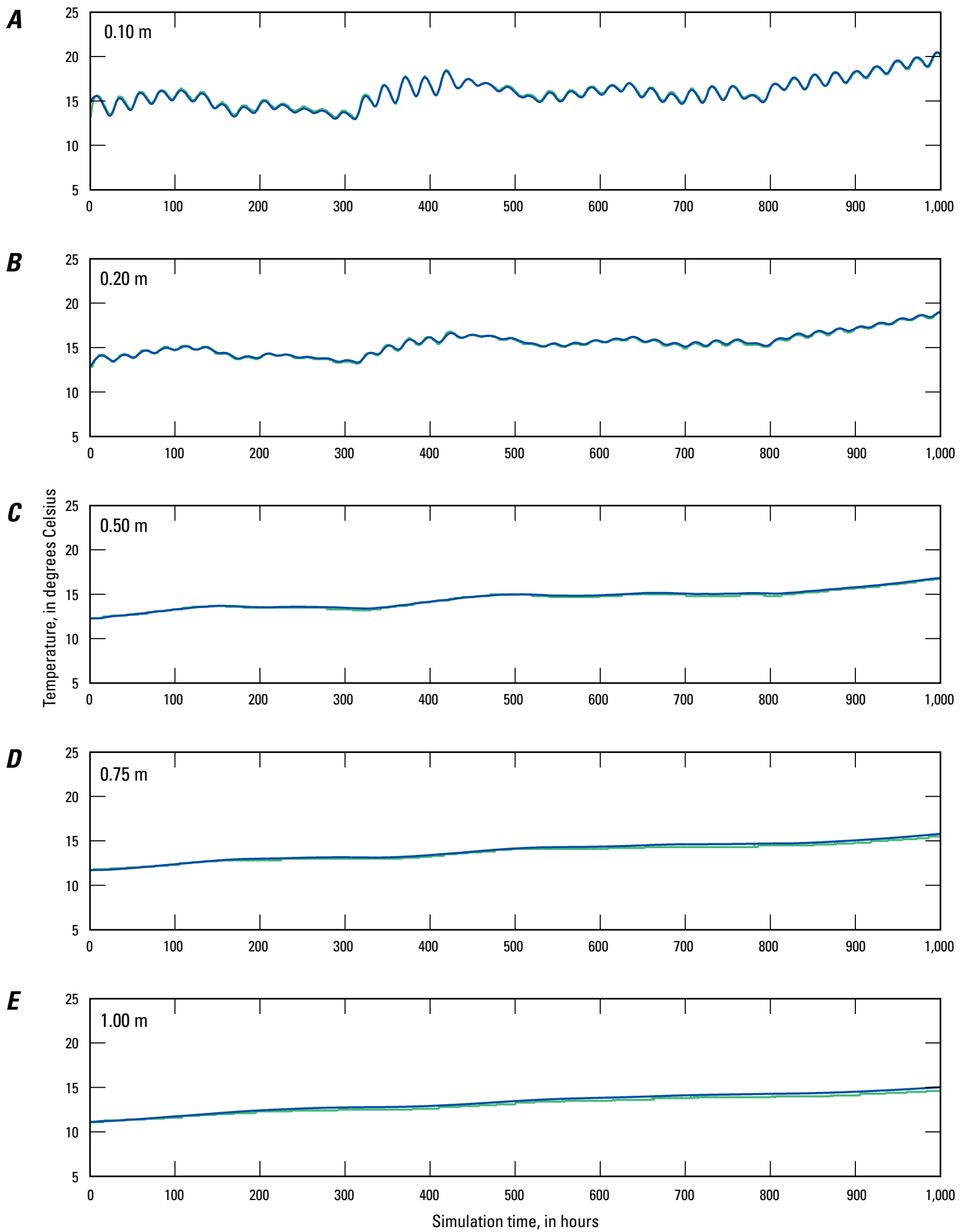

EXPLANATION

Measured

Simulated

Figure 1A-55. Measured and simulated thermographs for canal sediments for T15 at depths of A, $0.10 \mathrm{~m}, \mathrm{~B}, 0.20 \mathrm{~m}, \mathrm{C}, 0.50 \mathrm{~m}, \mathrm{D}, 0.75 \mathrm{~m}$, and $\mathrm{E}, 1.0 \mathrm{~m}$ for the 2013 calibration period. 

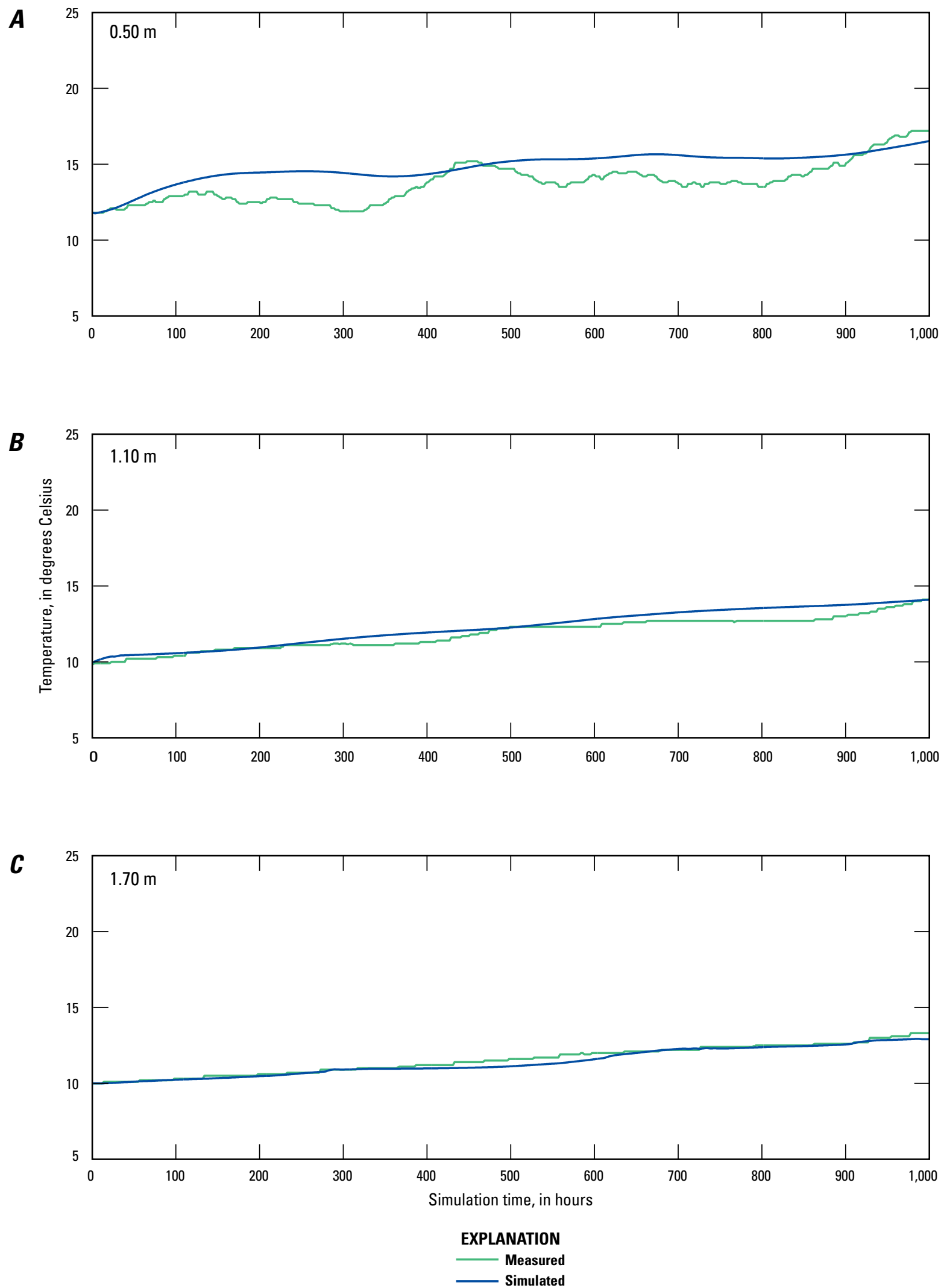

Figure 1A-56. Measured and simulated thermographs for Bank Piezometer 1 (BP1) at depths of $A, 0.50 \mathrm{~m}, \mathrm{~B}, 1.10 \mathrm{~m}$, and $\mathrm{C}, 1.70 \mathrm{~m}$ for the 2013 calibration period. 

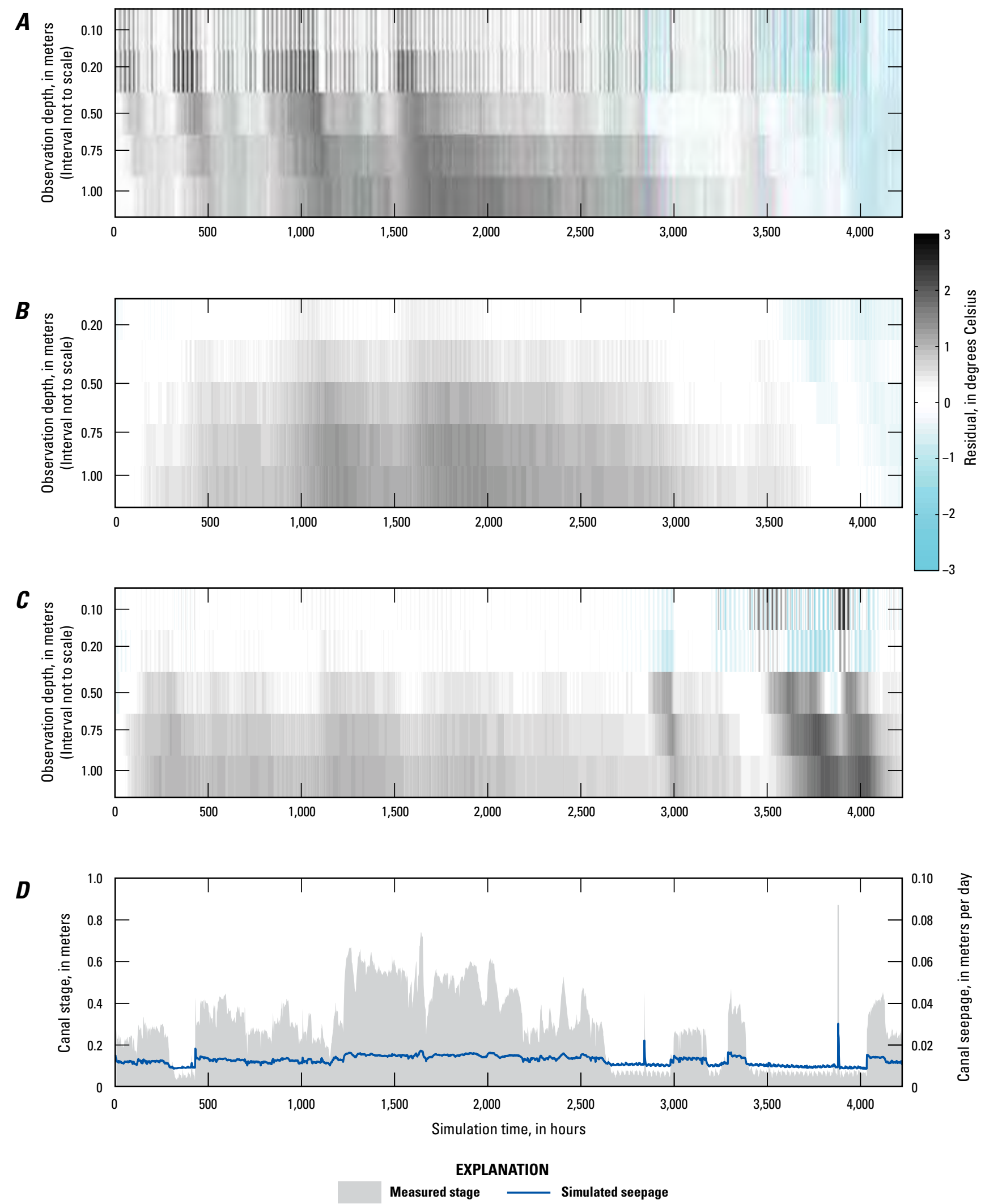

Figure 1A-57. Temperature residual for each depth below the canal at location $A, T 17, B, T 13$, and $C, T 15$, and $D$, measured stage and simulated seepage for the 2013 prediction period. 


\section{Appendix 1A Temperature and Model Results for Saroni Canal 4, Smith Valley, Nevada}

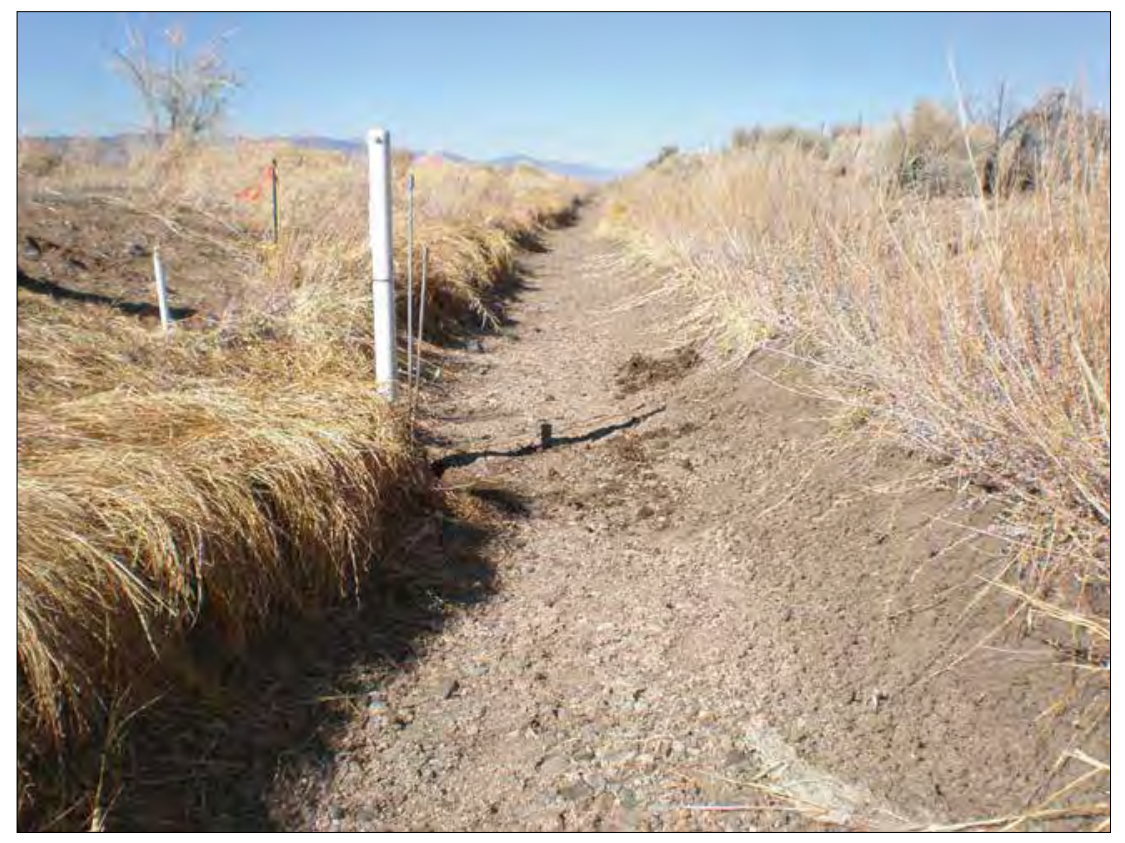

Figure 1A-58. Photograph of SARONI CANAL 4 site, Wellington, Nevada. Photograph taken by Steven Clarke, U.S. Geological Survey, looking downstream on 2/25/2013.

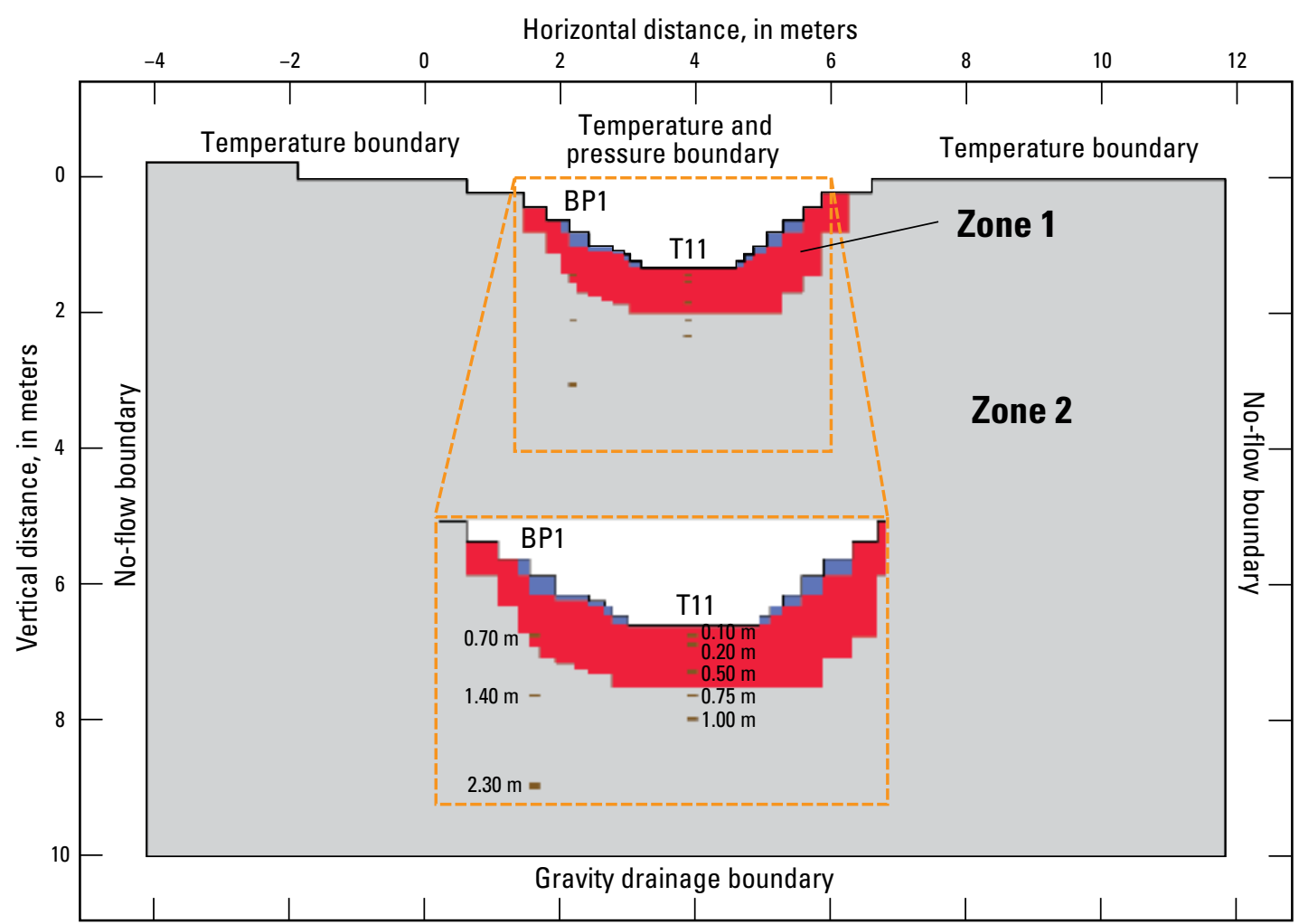

Figure 1A-59. Schematic cross section of two-dimensional VS2DH model of water and heat transport through canal-bed sediments at SARONI CANAL 4 site with soil textural zones (Zones 1-2), locations of temperature observations below ground surface within the canal (T11) and along the banks (BP1), and specified vertical and horizontal boundary conditions. 

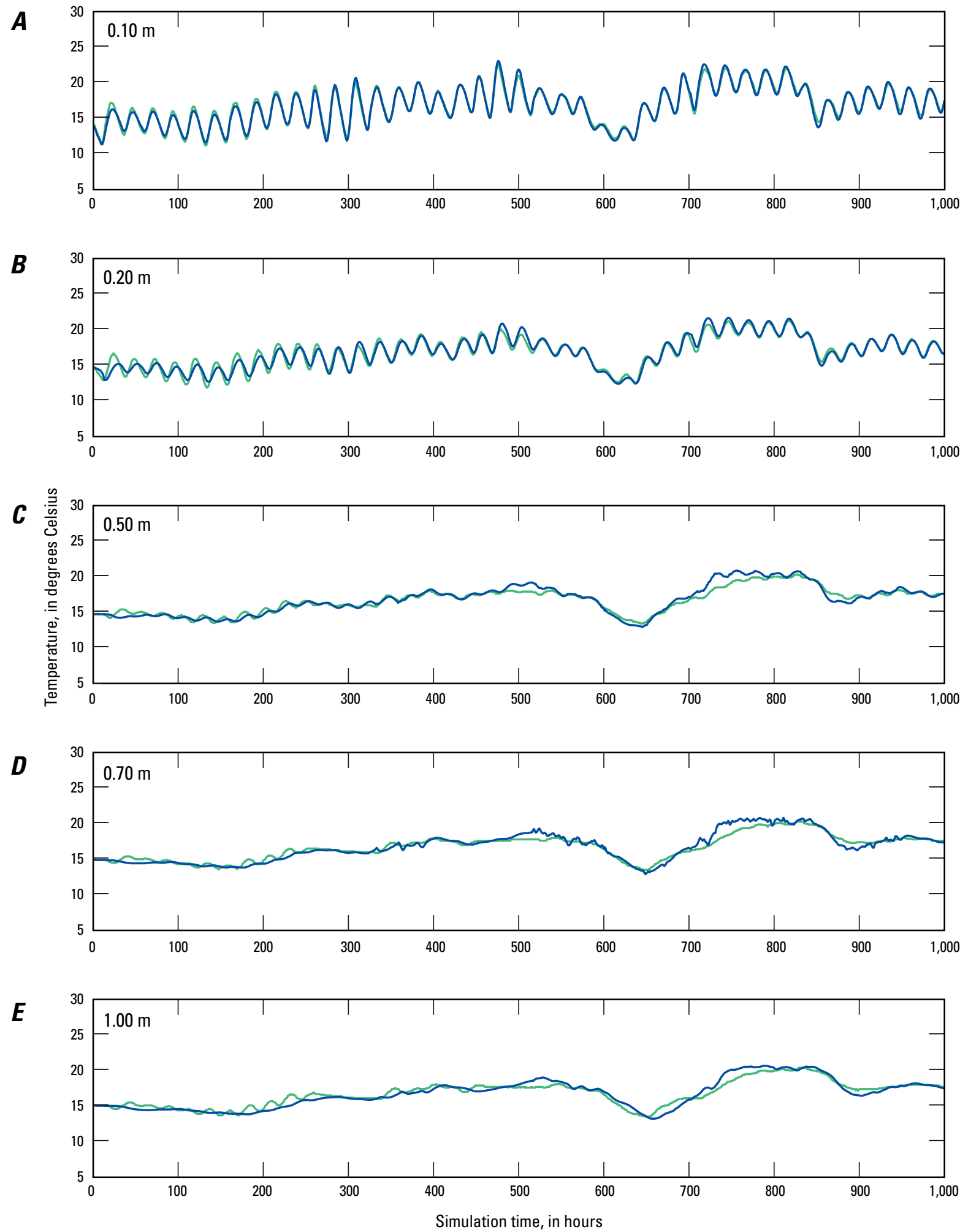

\section{EXPLANATION}

Measured

Simulated

Figure 1A-60. Measured and simulated thermographs for canal sediments for T11 at depths of $A, 0.10 \mathrm{~m}, \mathrm{~B}, 0.20 \mathrm{~m}, \mathrm{C}, 0.50 \mathrm{~m}, \mathrm{D}, 0.75 \mathrm{~m}$, and $E, 1.0 \mathrm{~m}$ for the 2012 calibration period. 

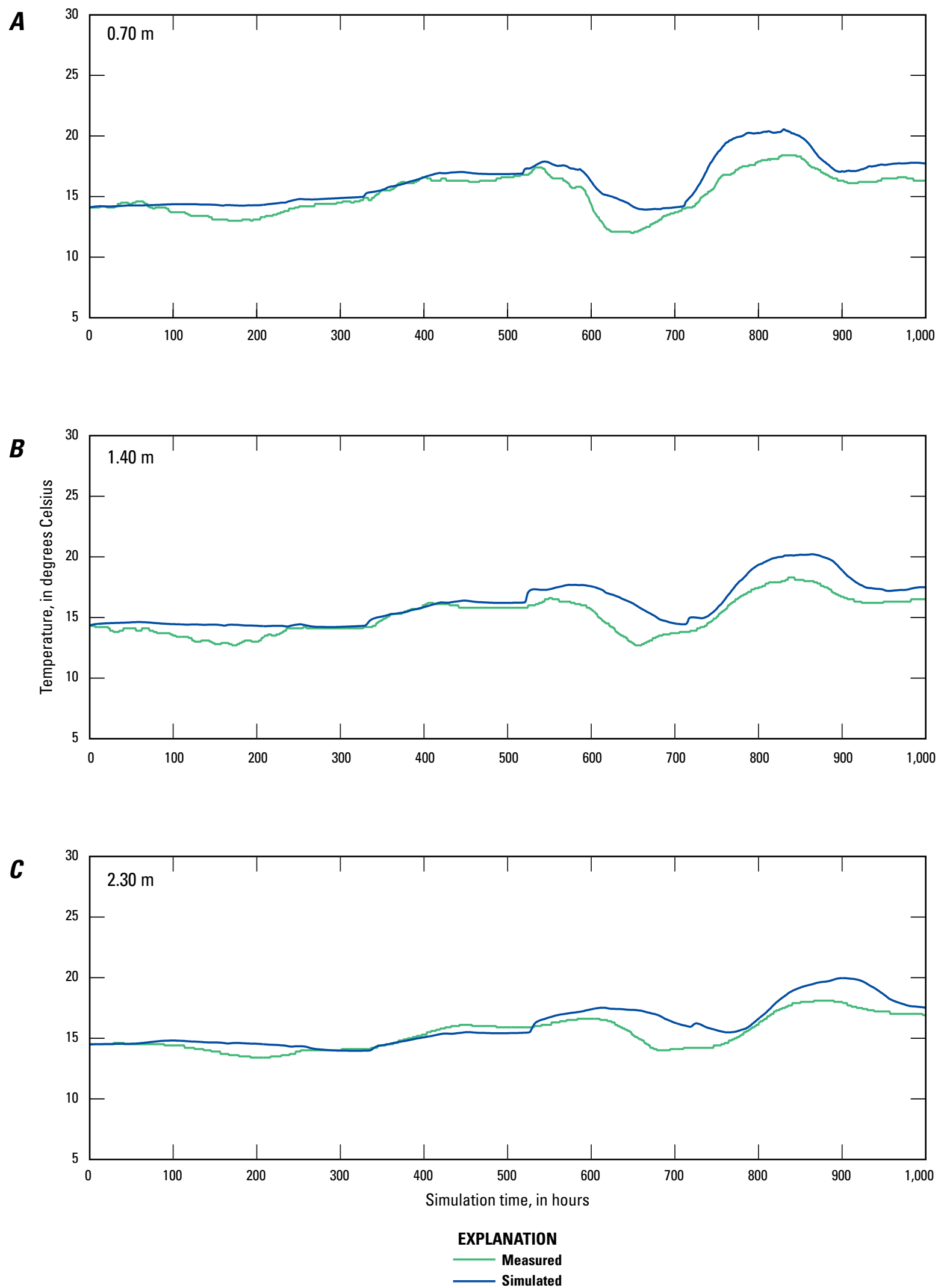

Figure 1A-61. Measured and simulated thermographs for Bank Piezometer 1 (BP1) at depths of $A, 0.70 \mathrm{~m}, \mathrm{~B}, 1.40 \mathrm{~m}$, and C, $2.30 \mathrm{~m}$ for the 2012 calibration period. 

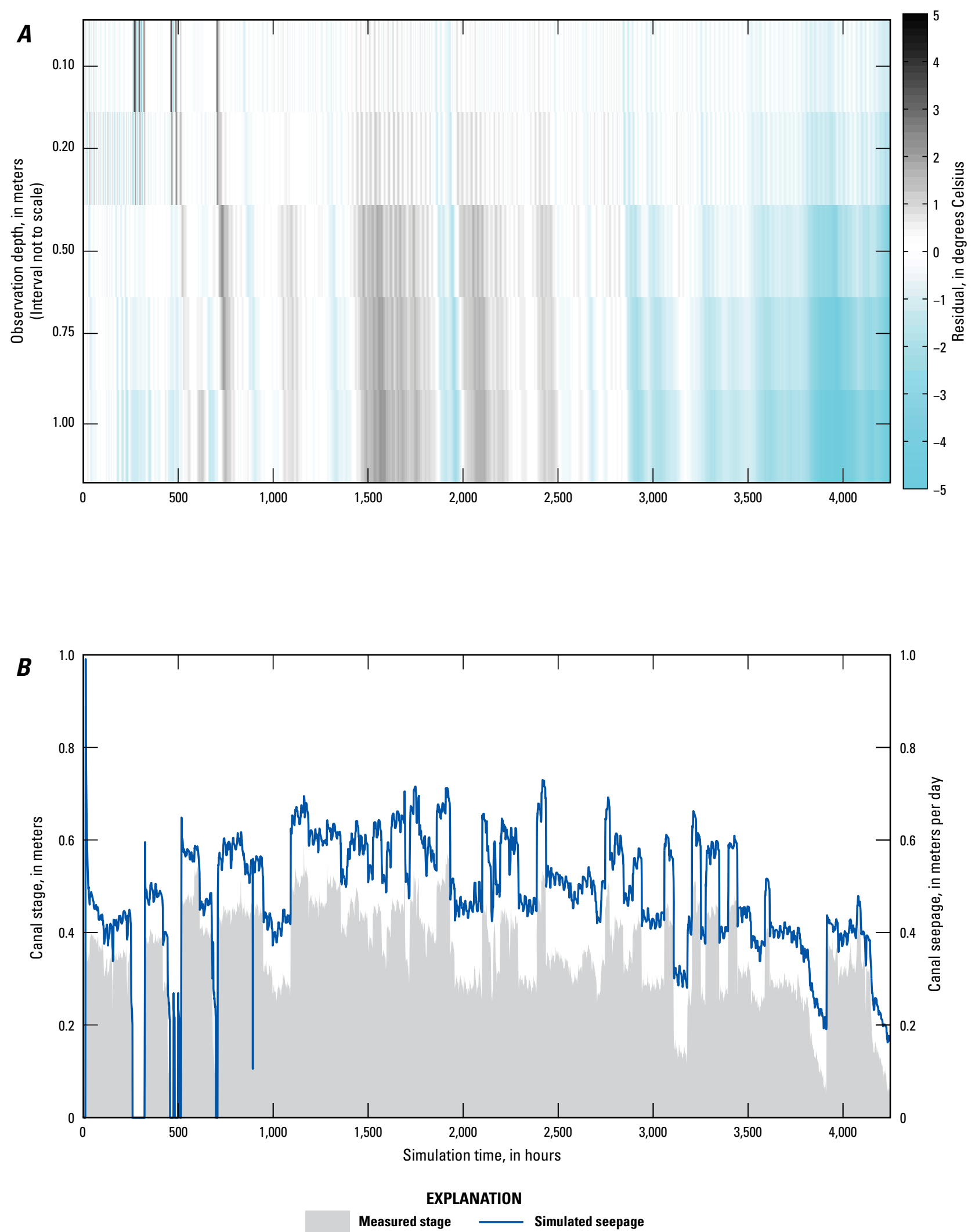

Figure 1A-62. Temperature residual for each depth below the canal at location $A, T 11$, and $B$, measured stage and simulated seepage for the 2012 prediction period. 

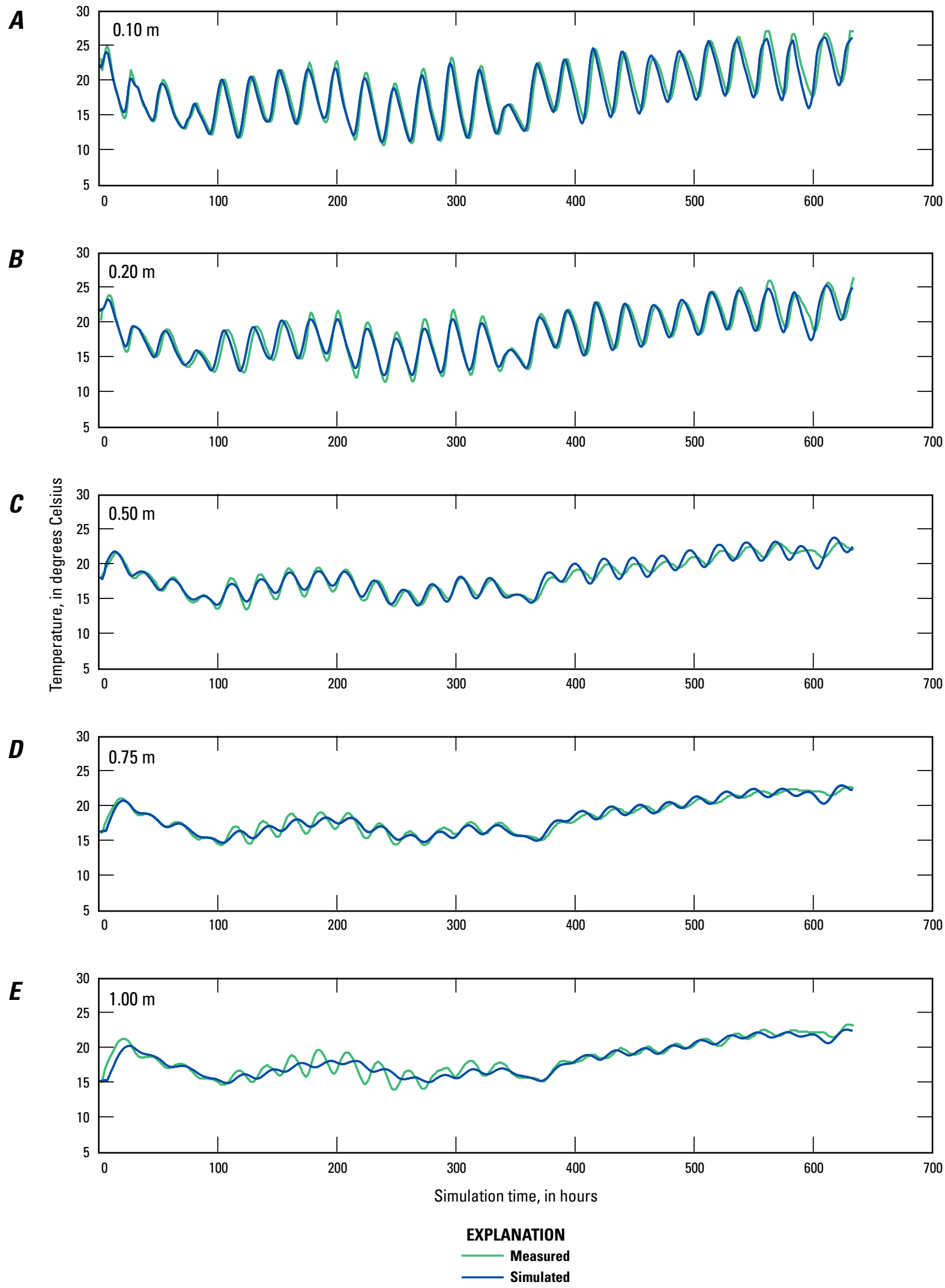

Figure 1A-63. Measured and simulated thermographs for canal sediments for T11 at depths of $A, 0.10 \mathrm{~m}, \mathrm{~B}, 0.20 \mathrm{~m}, \mathrm{C}, 0.50 \mathrm{~m}, \mathrm{D}, 0.75 \mathrm{~m}$, and $\mathrm{E}, 1.0 \mathrm{~m}$ for the 2013 calibration period. 

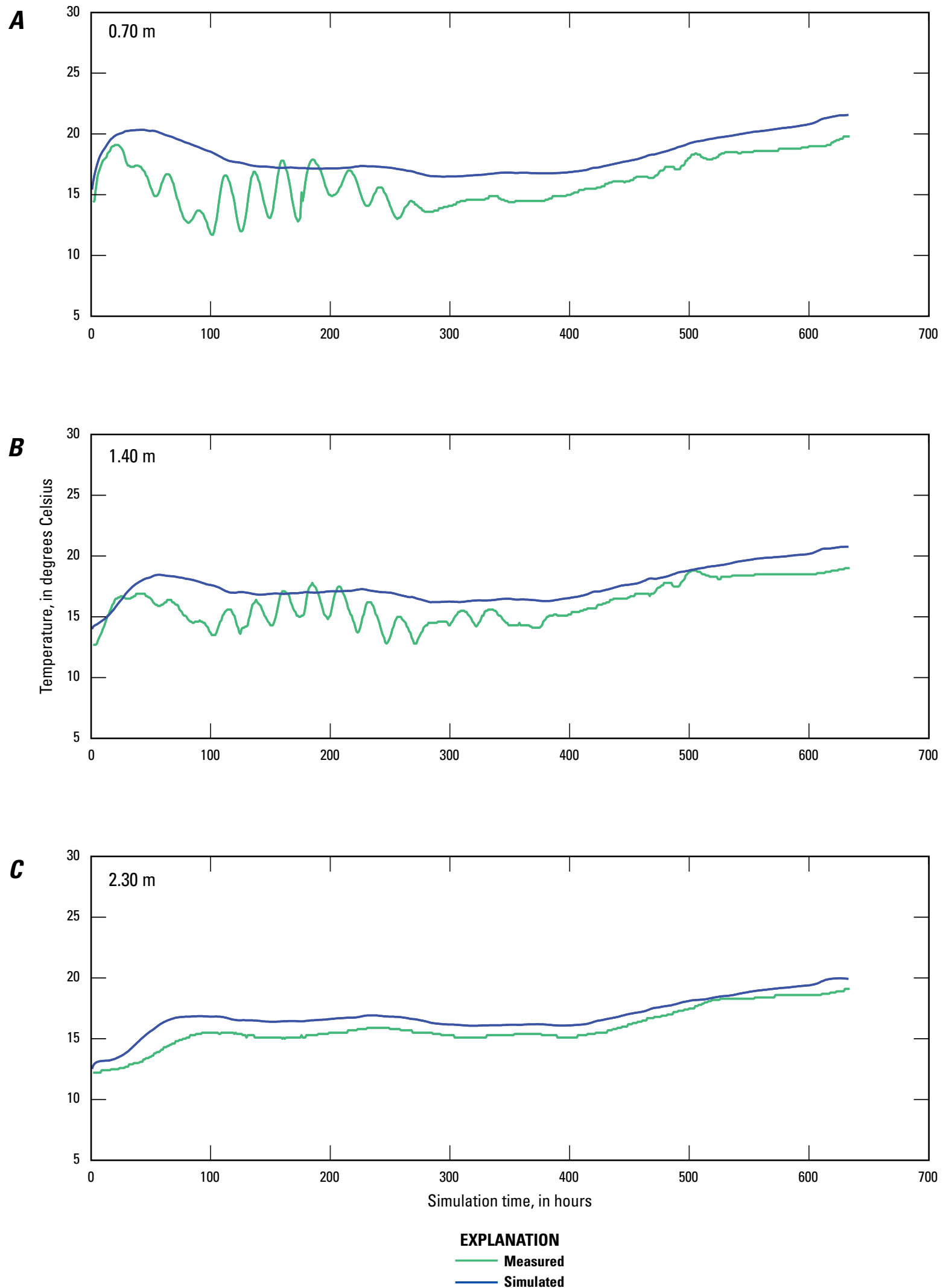

Figure 1A-64. Measured and simulated thermographs for Bank Piezometer 1 (BP1) at depths of $A, 0.70 \mathrm{~m}, \mathrm{~B}, 1.40 \mathrm{~m}$, and C, $2.30 \mathrm{~m}$ for the 2013 calibration period. 

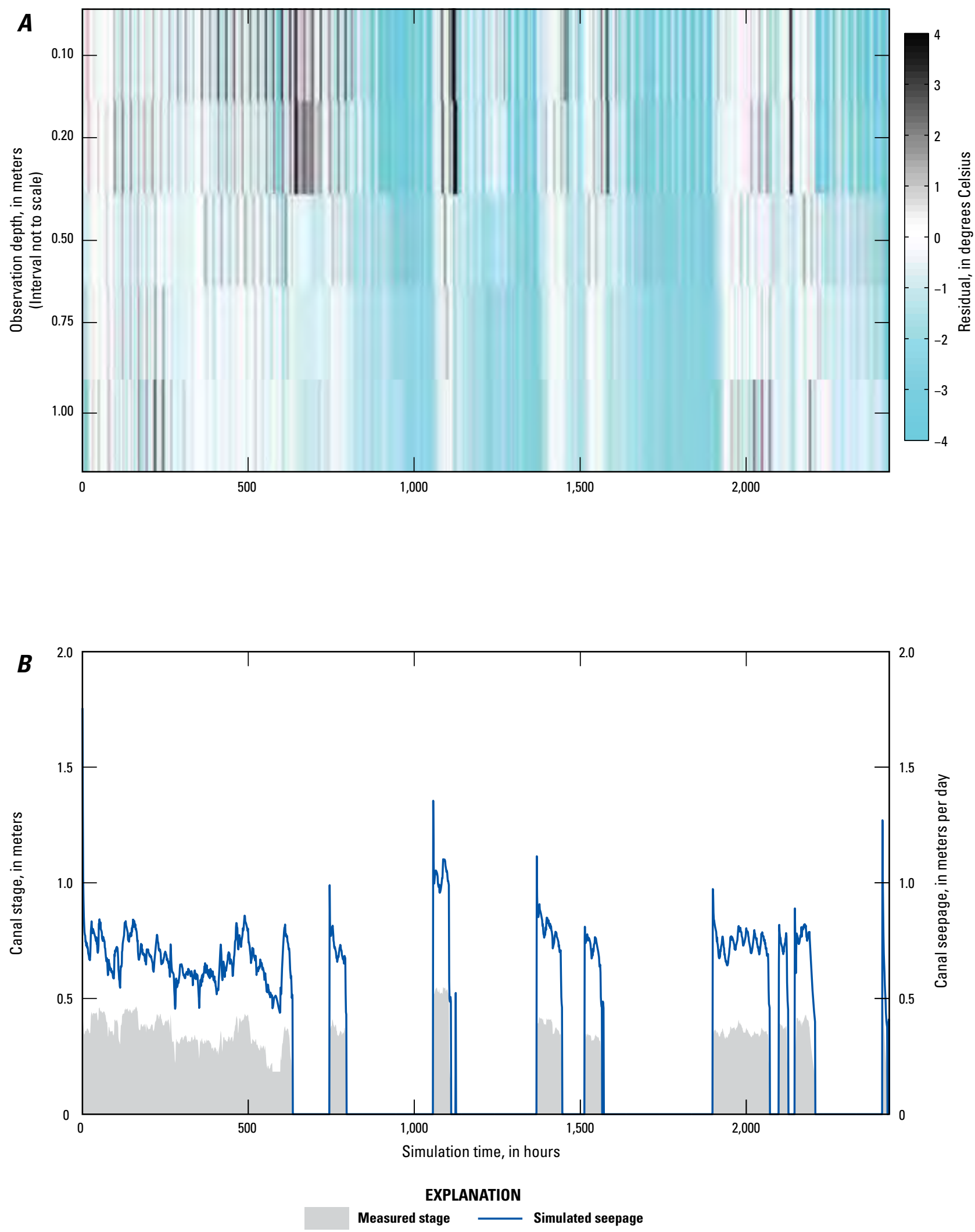

Figure 1A-65. Temperature residual for each depth below the canal at location $A, T 11$, and $B$, measured stage and simulated seepage for the 2013 prediction period. 


\section{Appendix 1B Temperature and Model Results for Plymouth Canal 1, Smith Valley, Nevada}

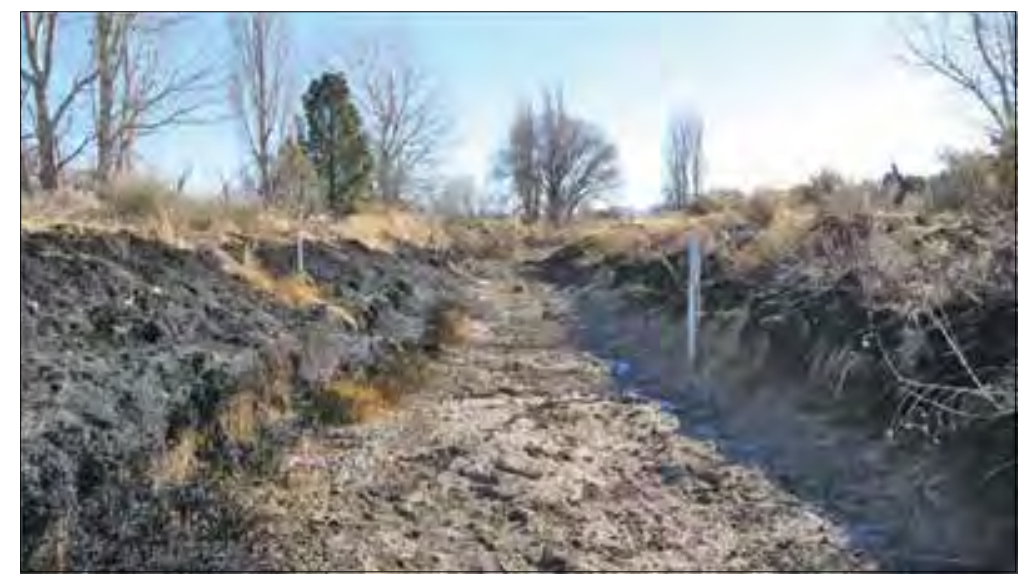

Figure 1B-1. Photograph of PLYMOUTH CANAL 1 site, Wellington, Nevada. Photograph taken by Steven Clarke, U.S. Geological Survey, looking downstream on 2/13/2013.

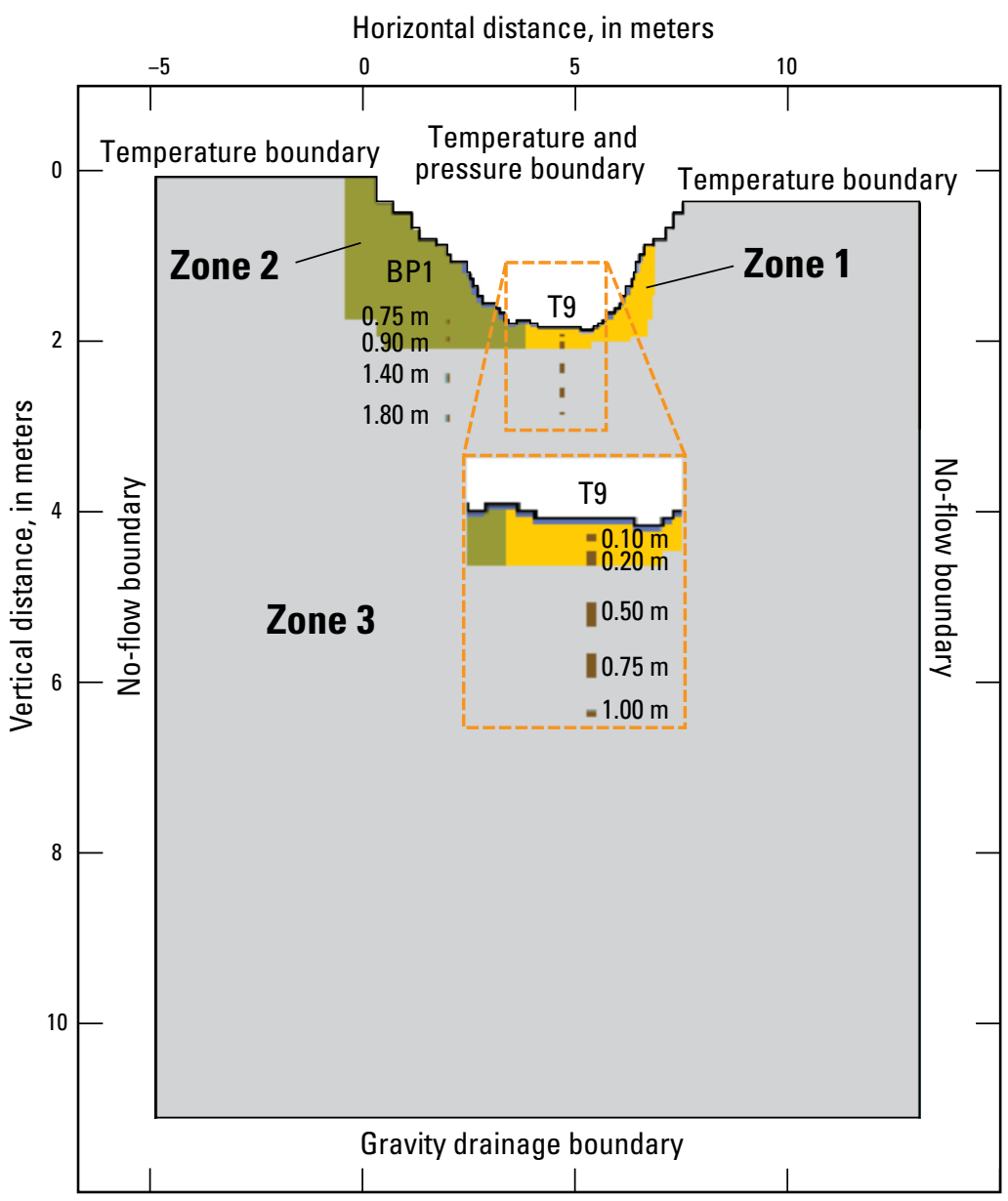

Figure 1B-2. Schematic cross section of two-dimensional VS2DH model of water and heat transport through canal-bed sediments at PLYMOUTH CANAL 1 site with soil textural zones (Zones 1-2), locations of temperature observations below ground surface within the canal (T9) and along the banks (BP1), and specified vertical and horizontal boundary conditions. 

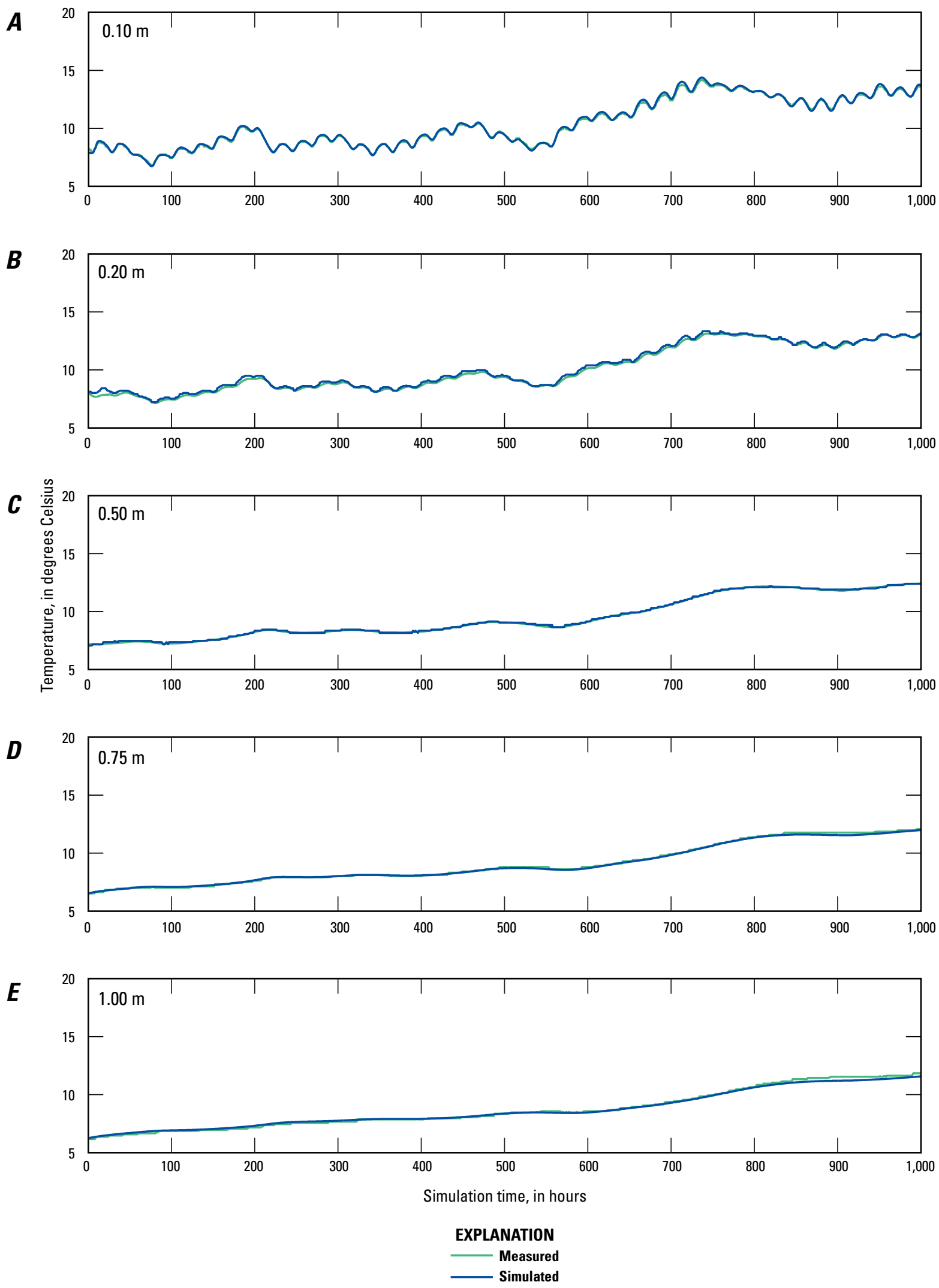

Figure 1B-3. Measured and simulated thermographs for canal sediments for T9 at depths of $A, 0.10 \mathrm{~m}, \mathrm{~B}, 0.20 \mathrm{~m}, \mathrm{C}, 0.50 \mathrm{~m}, \mathrm{D}, 0.75 \mathrm{~m}$, and $\mathrm{E}, 1.0 \mathrm{~m}$ for the 2012 calibration period. 

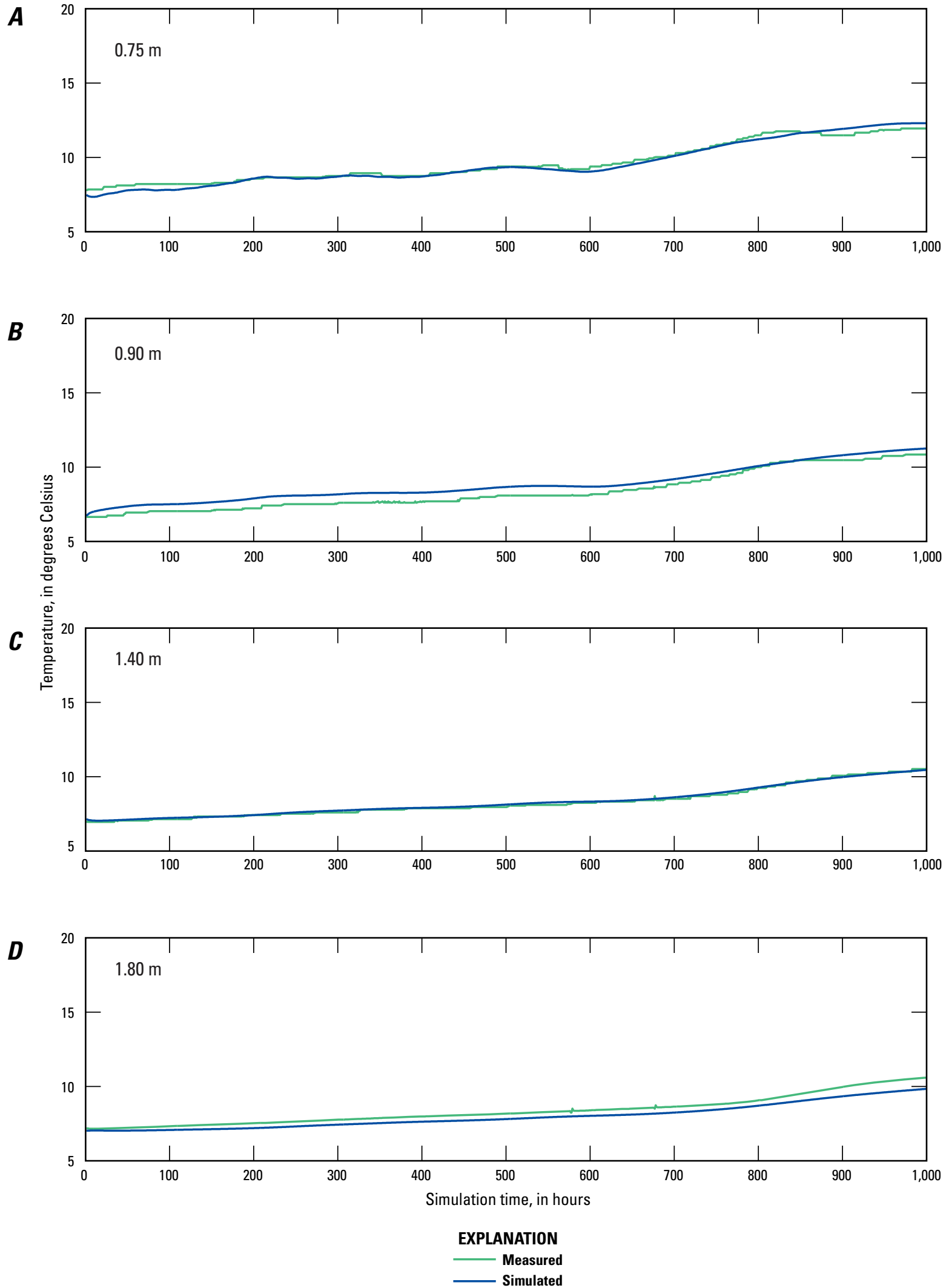

Figure 1B-4. Measured and simulated thermographs for Bank Piezometer 1 (BP1) observations at depths of $A, 0.75 \mathrm{~m}, \mathrm{~B}, 0.90 \mathrm{~m}$, $\mathrm{C}, 1.40 \mathrm{~m}$, and $\mathrm{D}, 1.80 \mathrm{~m}$ for the 2012 calibration period. 

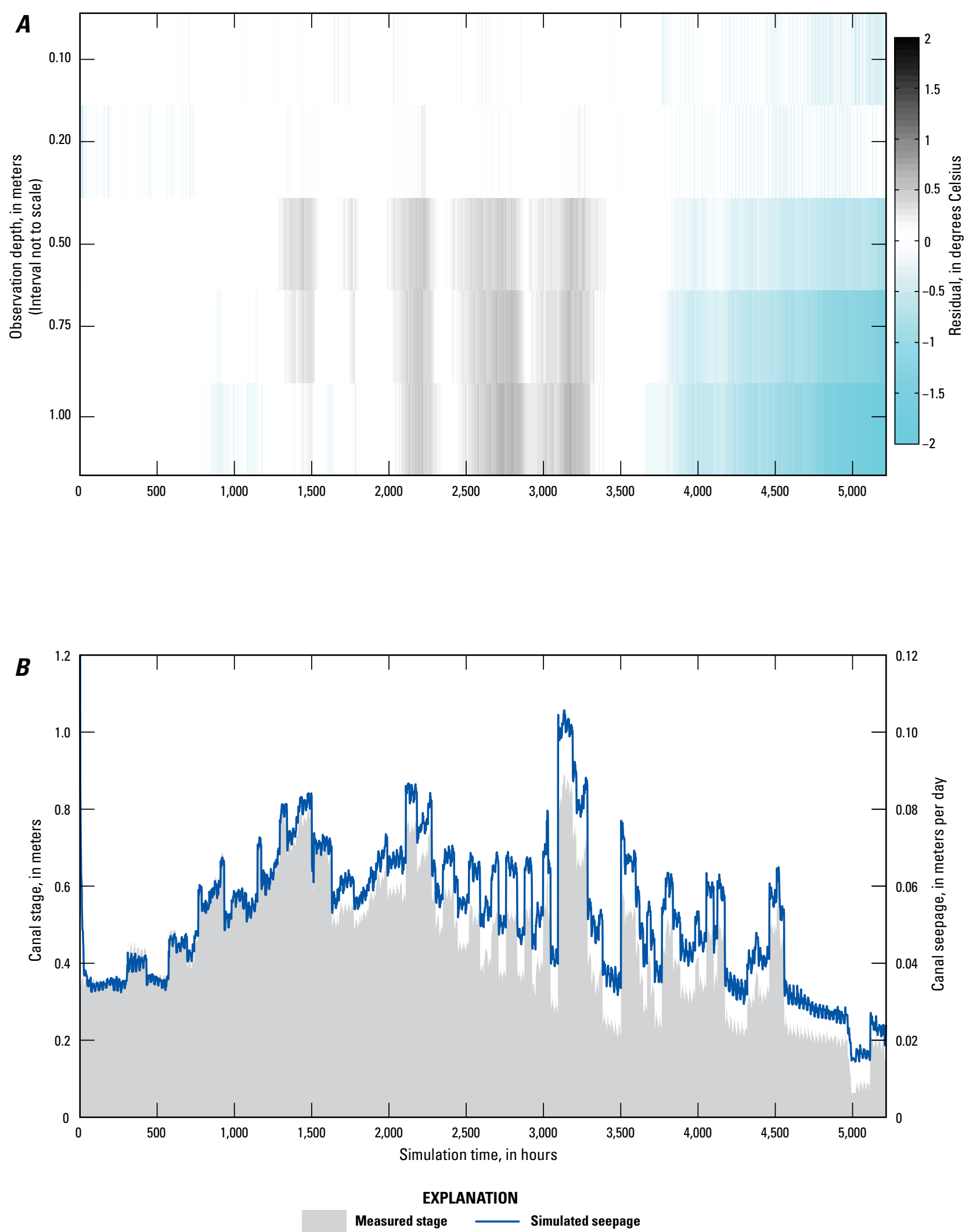

Figure 1B-5. Temperature residual for each depth below the canal at location A, $T 9$, and B, measured stage and simulated seepage for the 2012 prediction period. 

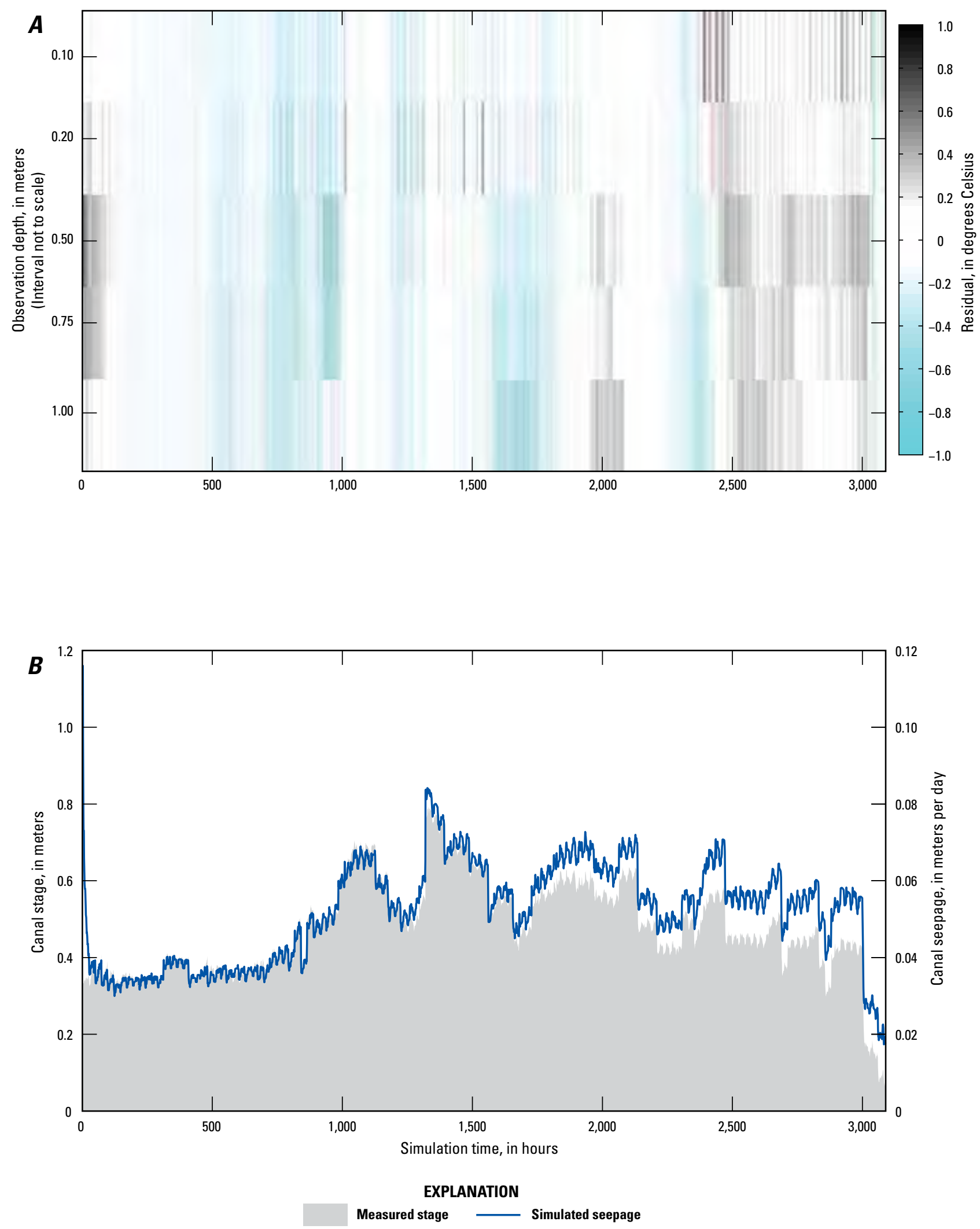

Figure 1B-6. Temperature residual for each depth below the canal at location A, T9, and B, measured stage and simulated seepage for the 2013 prediction period. 


\section{Appendix 1B Temperature and Model Results for Plymouth Canal 2, Smith Valley, Nevada}

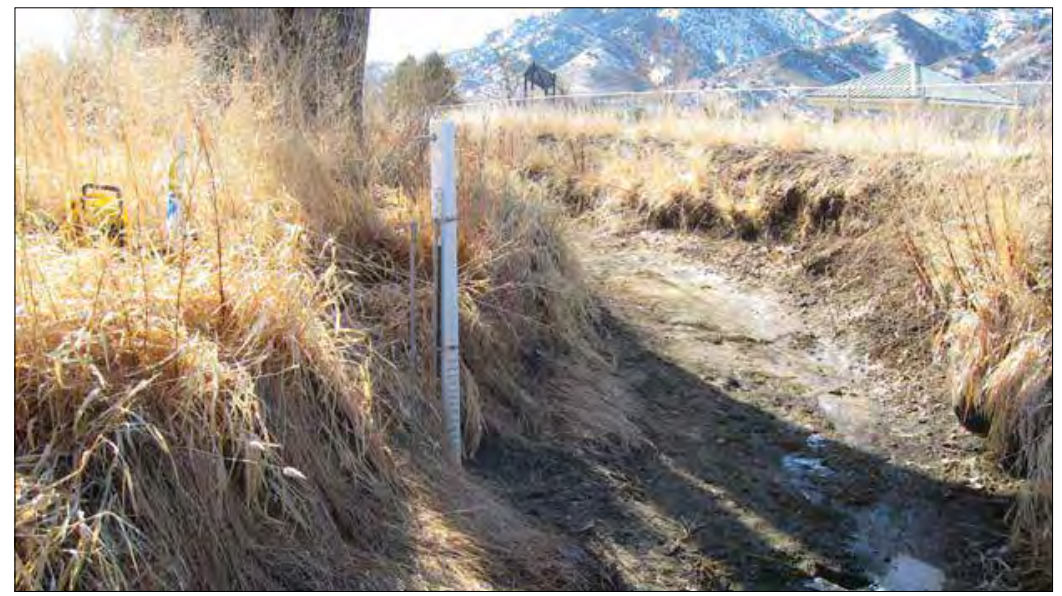

Figure 2B-7. Photograph of PLYMOUTH CANAL 2 site, Wellington, Nevada. Photograph taken by David W. Smith, U.S. Geological Survey, looking upstream on 2/12/2013.

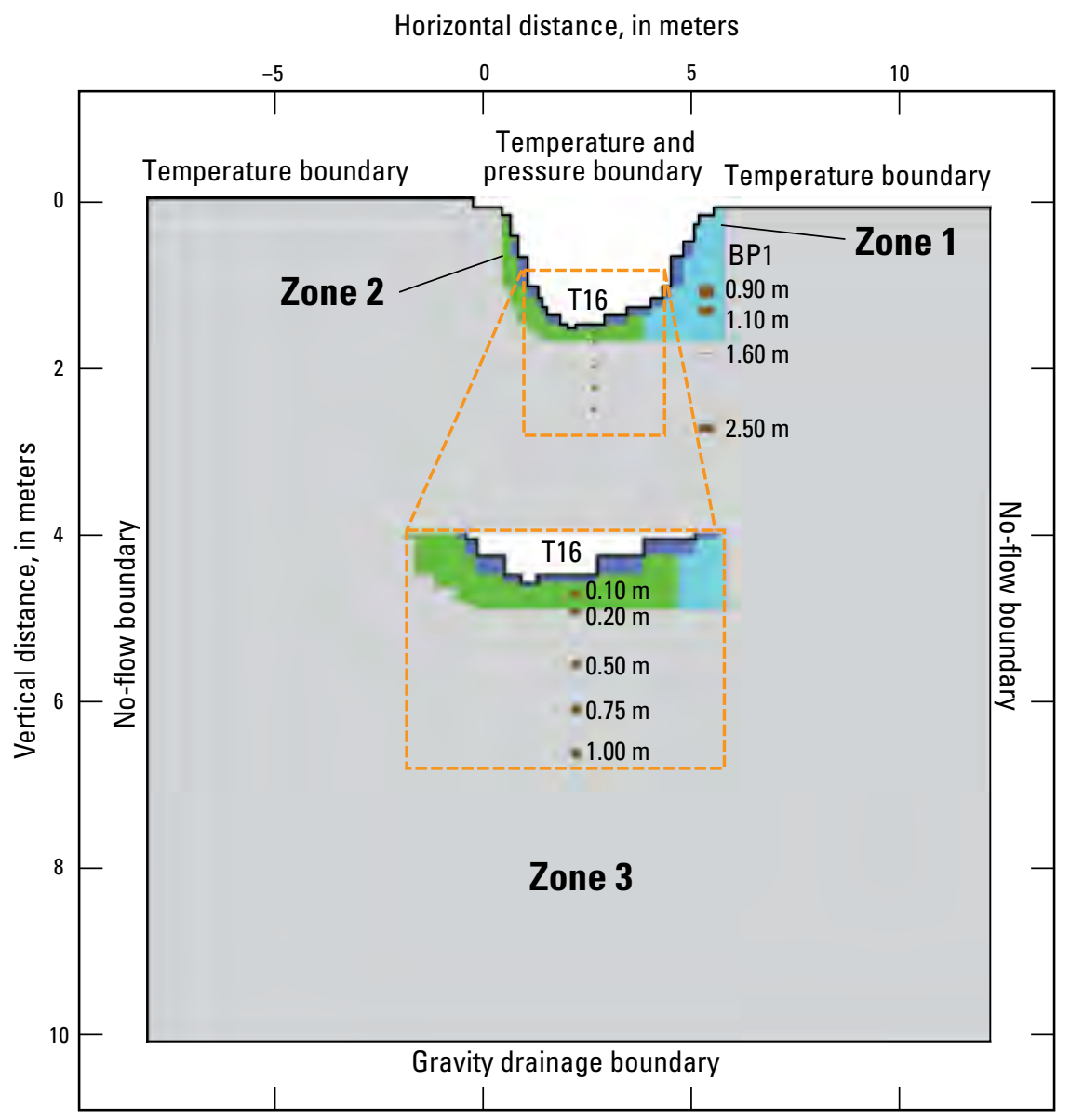

Figure 1B-8. Schematic cross section of two-dimensional VS2DH model of water and heat transport through canal-bed sediments at PLYMOUTH CANAL 2 site with soil textural zones (Zones 1-3), locations of temperature observations below ground surface within the canal (T16) and along the banks (BP1), and specified vertical and horizontal boundary conditions. 

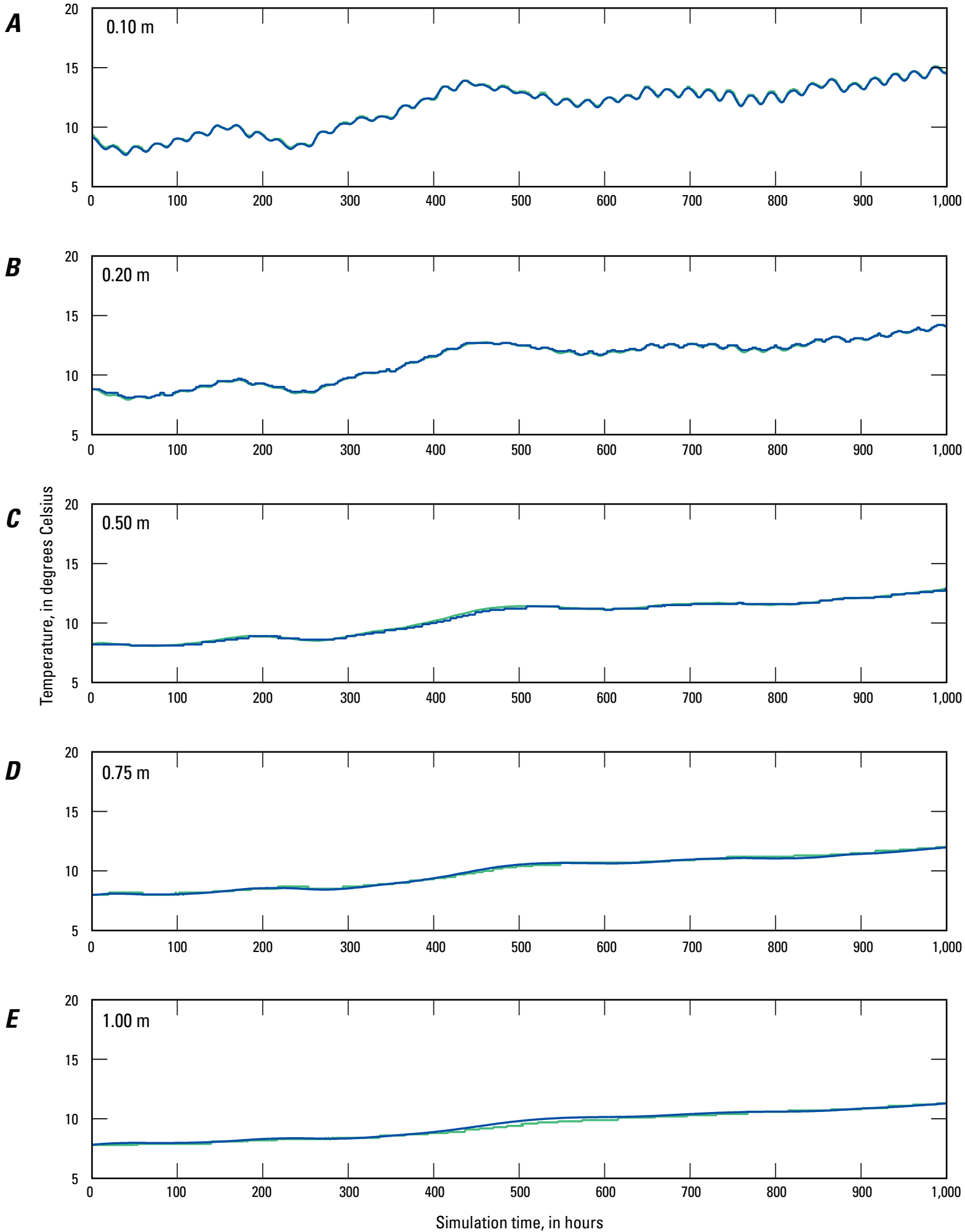

EXPLANATION

Measured

Simulated

Figure 1B-9. Measured and simulated thermographs for canal sediments for T16 at depths of $A, 0.10 \mathrm{~m}, \mathrm{~B}, 0.20 \mathrm{~m}, \mathrm{C}, 0.50 \mathrm{~m}, \mathrm{D}, 0.75 \mathrm{~m}$, and $\mathrm{E}, 1.0 \mathrm{~m}$ for the 2012 calibration period. 

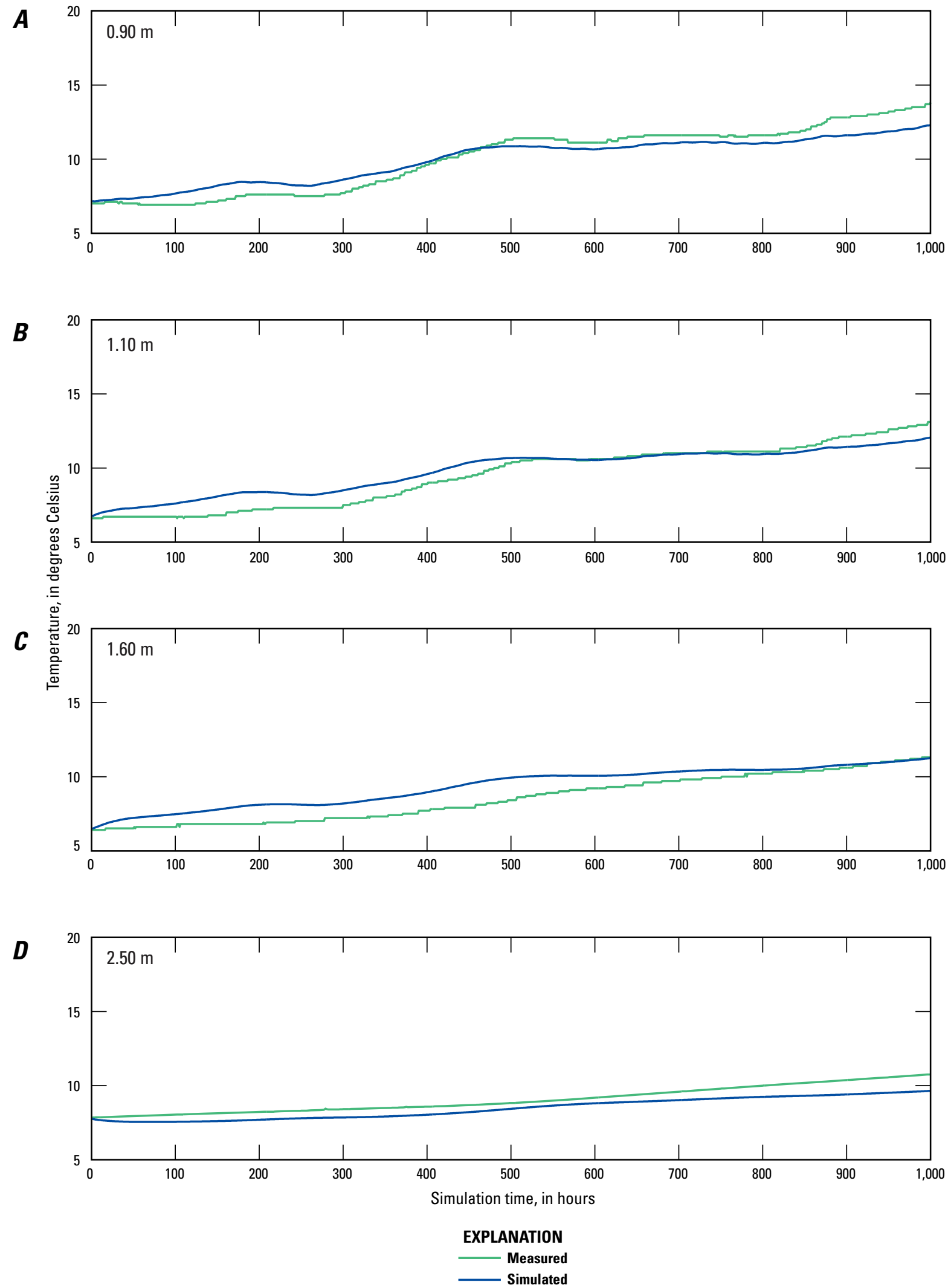

Figure 1B-10. Measured and simulated thermographs for Bank Piezometer 1 (BP1) observations at depths of $A, 0.90 \mathrm{~m}, \mathrm{~B}, 1.10 \mathrm{~m}$, $\mathrm{C}, 1.60 \mathrm{~m}$, and $\mathrm{D}, 2.50 \mathrm{~m}$ for the 2012 calibration period. 

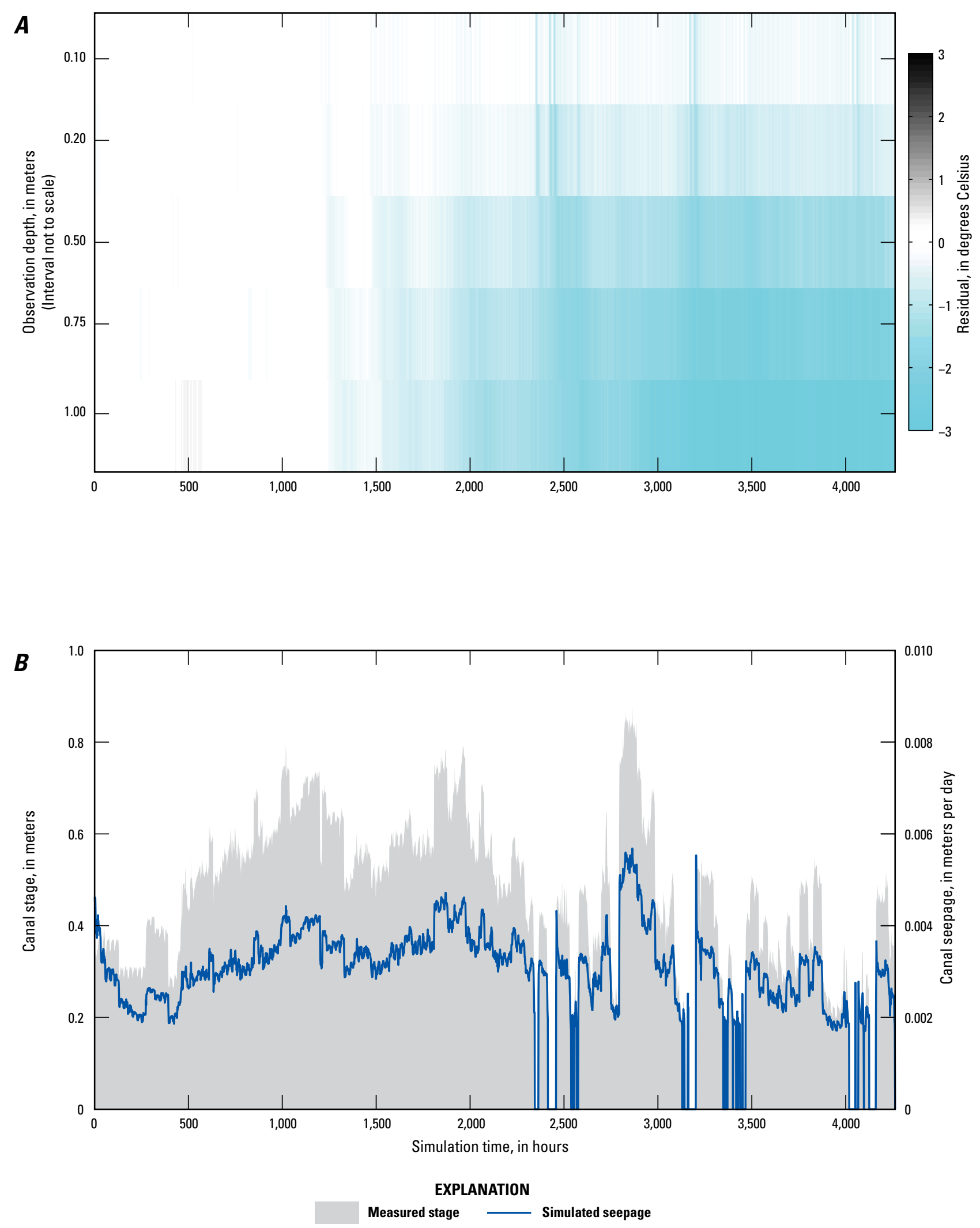

Figure 1B-11. Temperature residual for each depth below the canal at location A, T16, and B, measured stage and simulated seepage for the 2012 prediction period. 

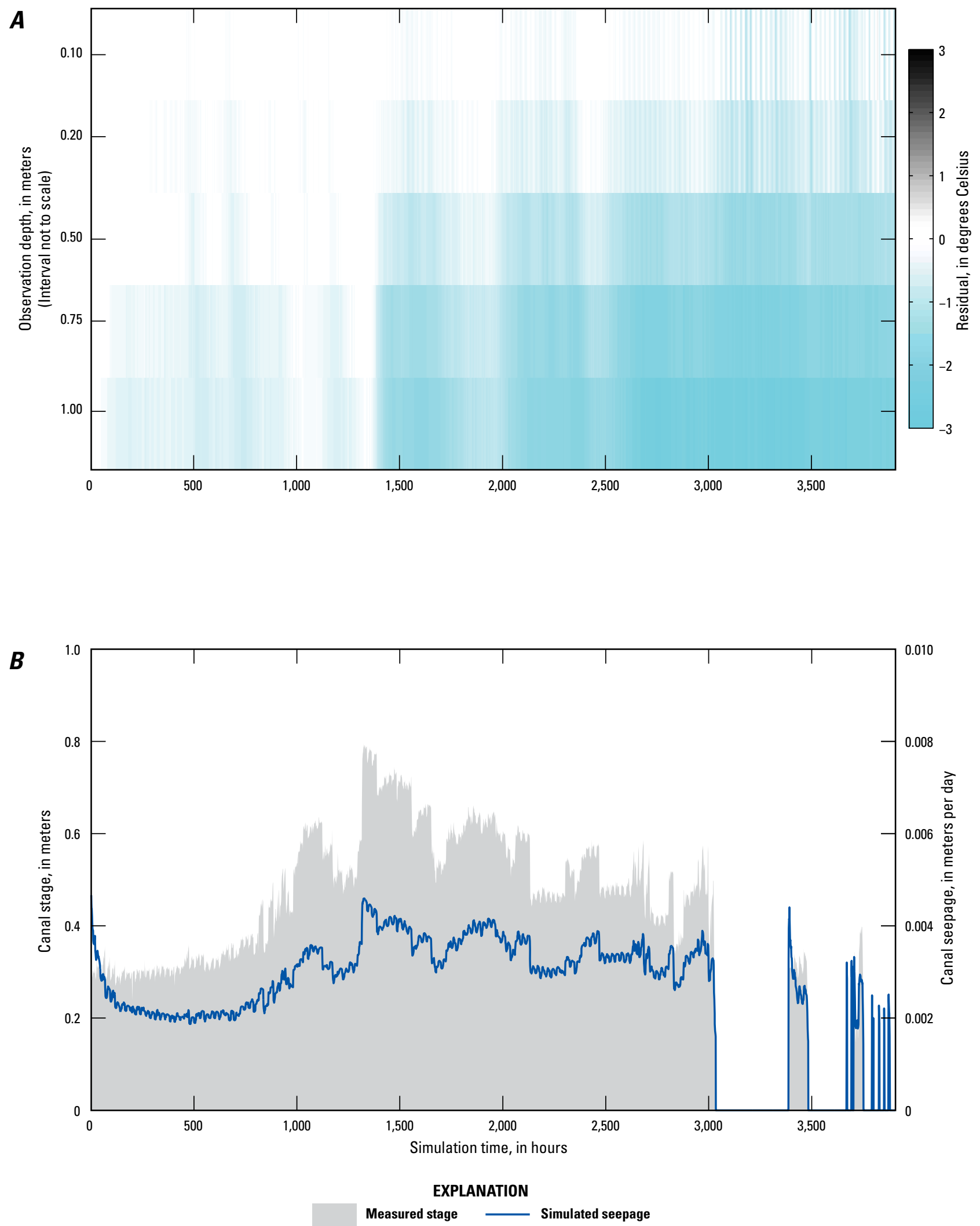

Figure 1B-12. Temperature residual for each depth below the canal at location A, T16, and B, measured stage and simulated seepage for the 2013 prediction period. 


\section{Appendix 2A Temperature and Model Results for Fox Ditch 1, Mason Valley, Nevada}

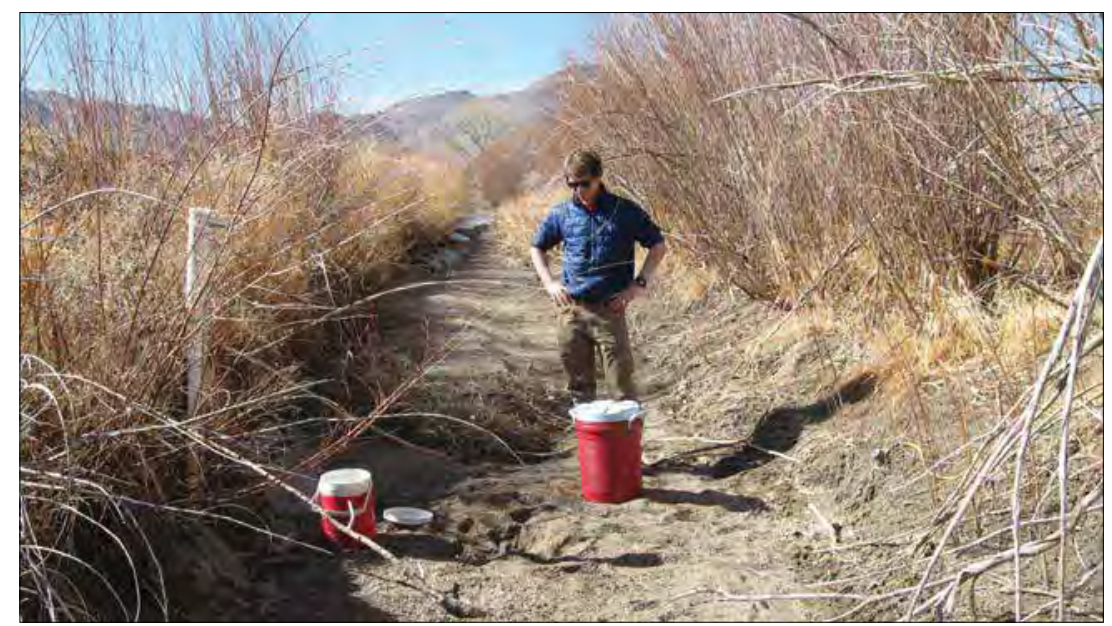

Figure 2A-1. Photograph of FOX DITCH 1 site, Yerrington, Nevada. Photograph taken by Steven Clarke, U.S. Geological Survey, looking downstream on 2/12/2013.

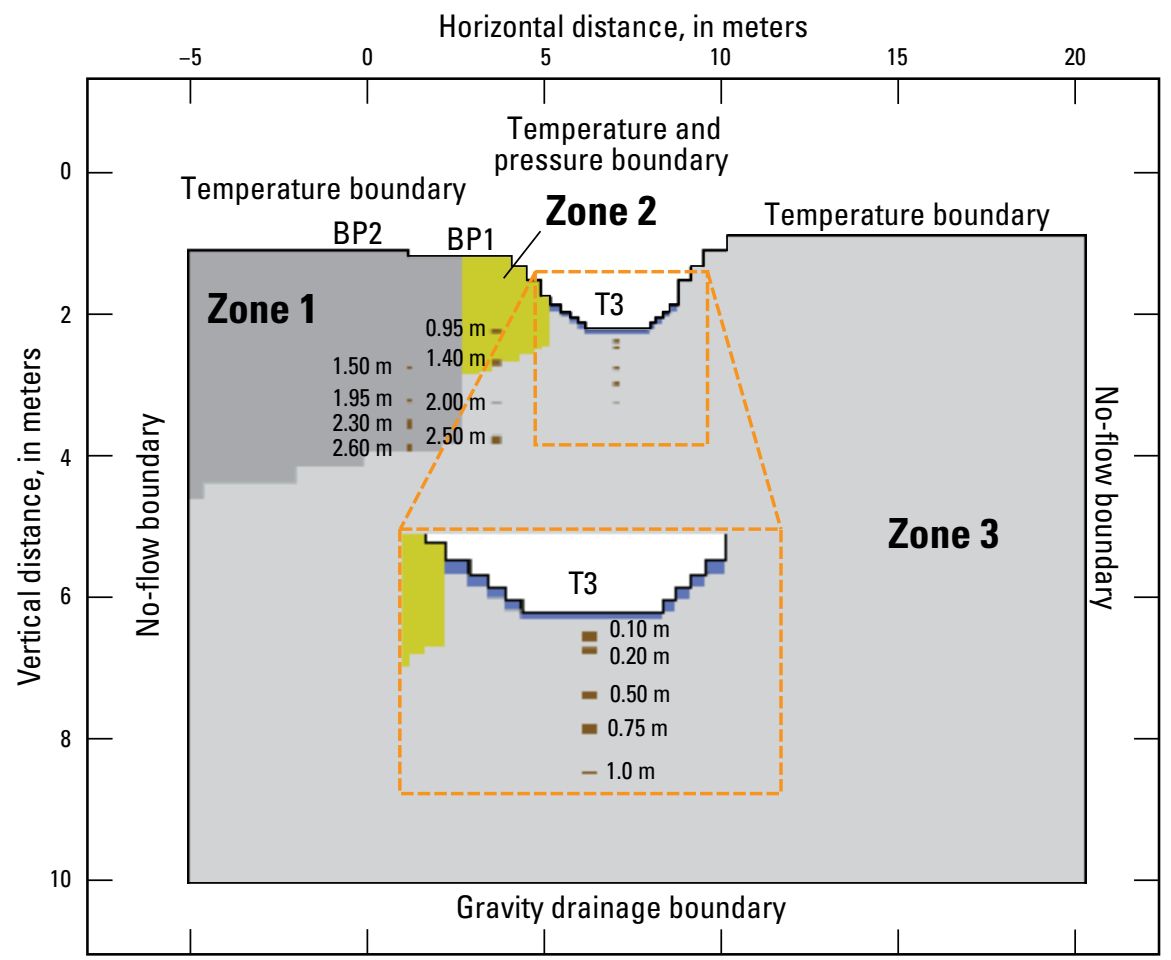

Figure 2A-2. Schematic cross section of two-dimensional VS2DH model of water and heat transport through canal-bed sediments at FOX DITCH 1 site with soil textural zones (Zones 1-3), locations of temperature observations below ground surface within the canal (T3) and along the banks (BP1 and BP2), and specified vertical and horizontal boundary conditions. 


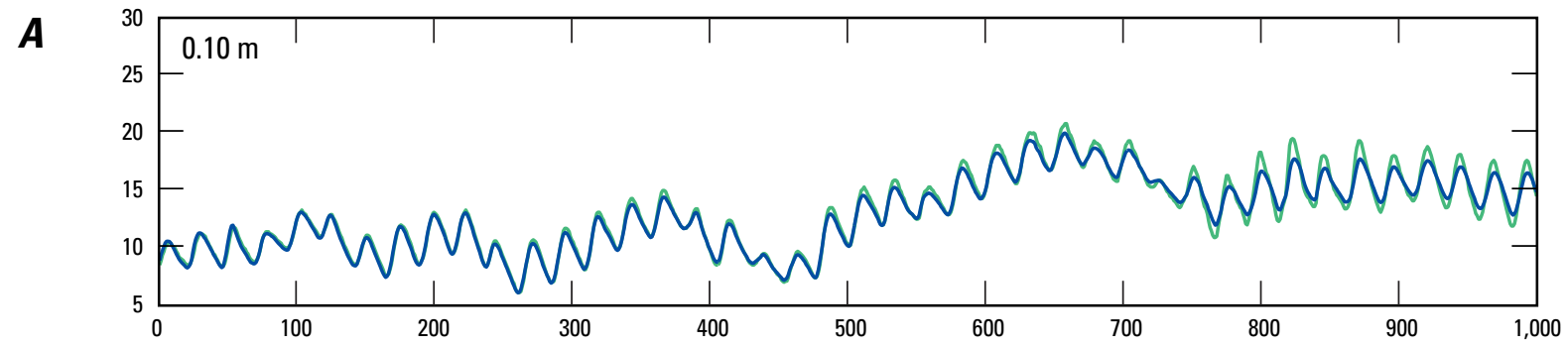

B
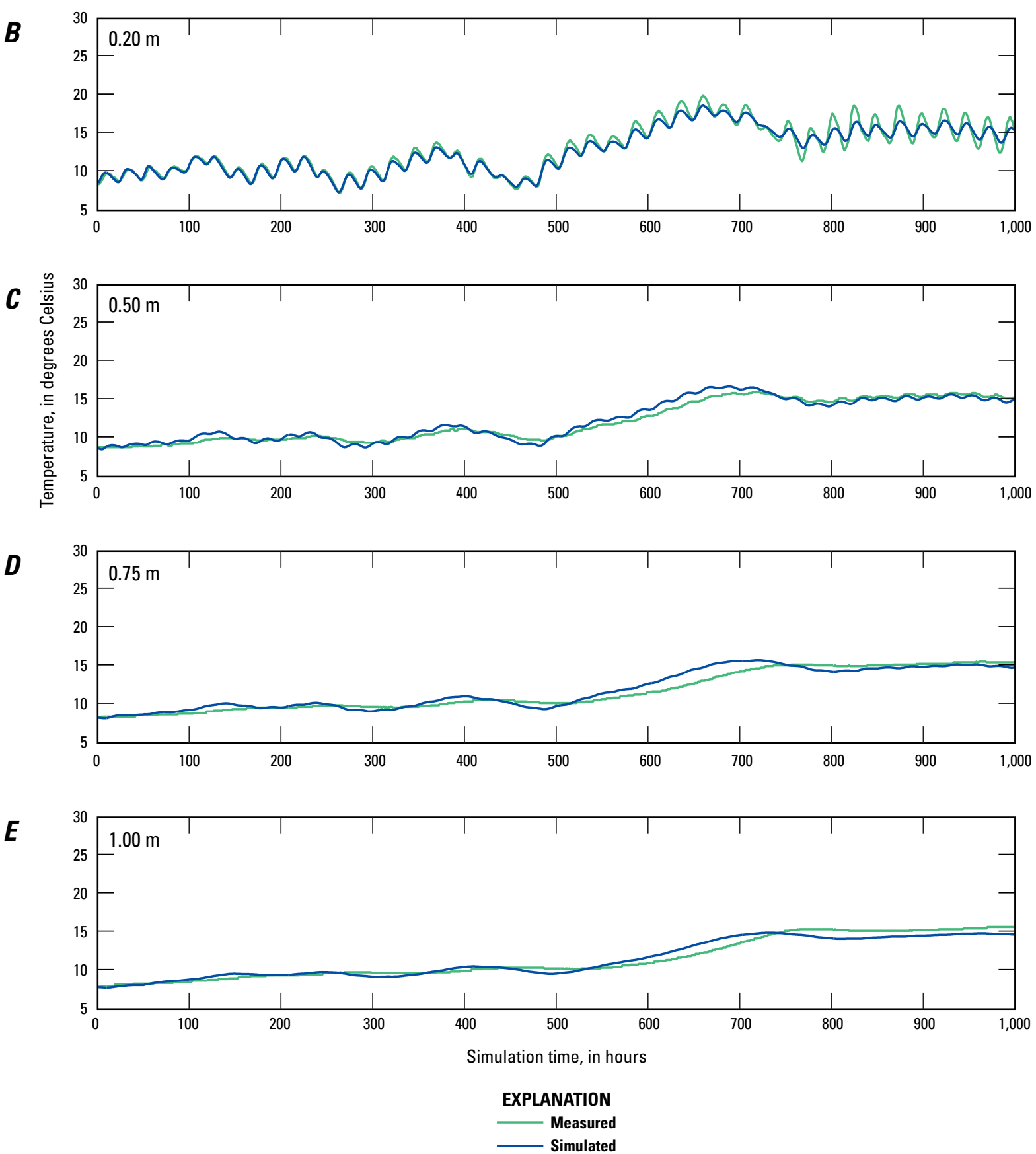

Figure 2A-3. Measured and simulated thermographs for canal sediments for T3 at depths of $A, 0.10 \mathrm{~m}, \mathrm{~B}, 0.20 \mathrm{~m}, \mathrm{C}, 0.50 \mathrm{~m}, \mathrm{D}, 0.75 \mathrm{~m}$, and $\mathrm{E}, 1.0 \mathrm{~m}$ for the 2012 calibration period. 

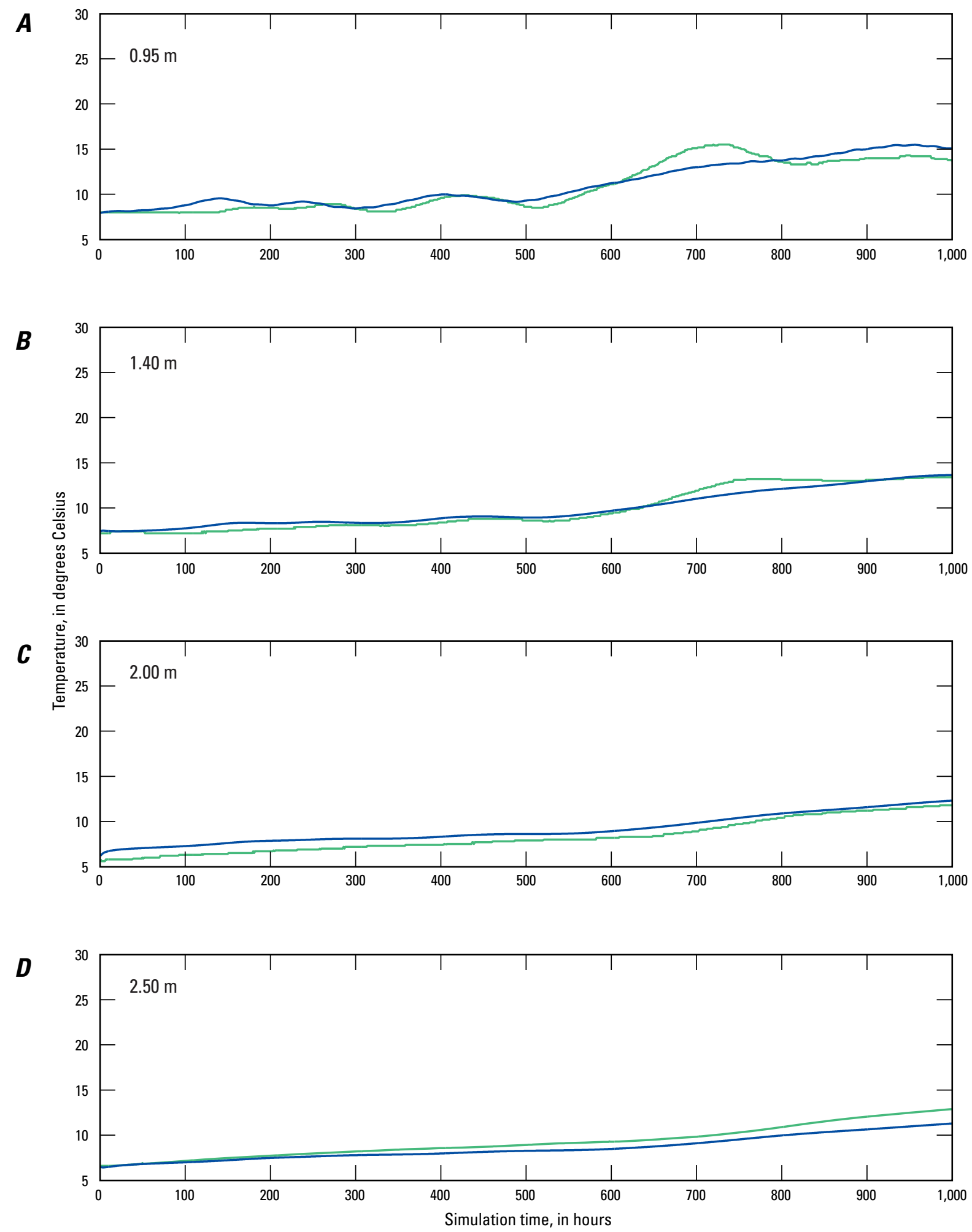

EXPLANATION

Measured

Simulated

Figure 2A-4. Measured and simulated thermographs for Bank Piezometer 1 (BP1) observations at depths of $A, 0.95 \mathrm{~m}, B, 1.40 \mathrm{~m}$, C, $2.0 \mathrm{~m}$, and D, $2.50 \mathrm{~m}$ for the 2012 calibration period. 

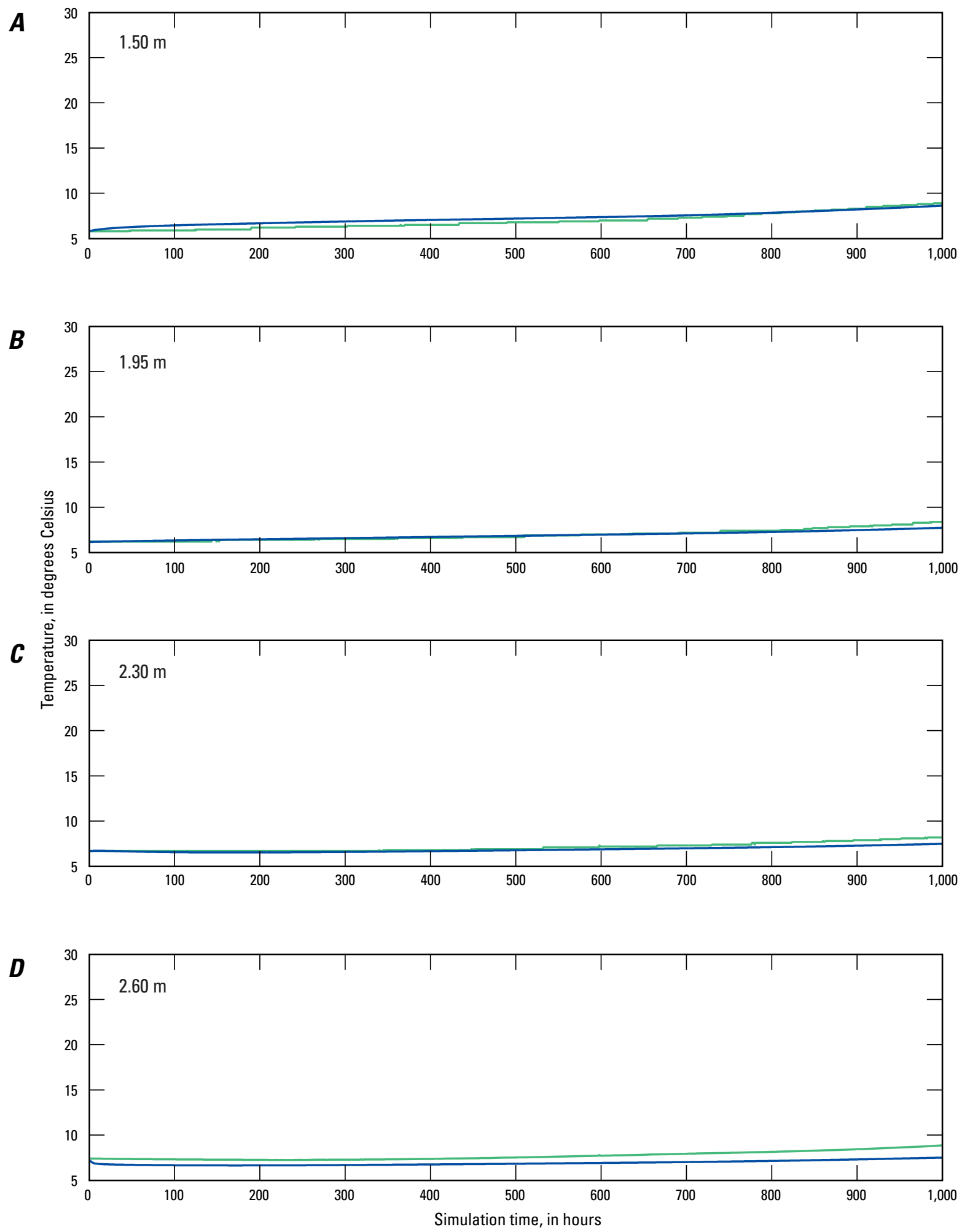

EXPLANATION

Measured

Simulated

Figure 2A-5. Measured and simulated thermographs for Bank Piezometer 2 (BP2) observations at depths of $A, 1.50 \mathrm{~m}, \mathrm{~B}, 1.95 \mathrm{~m}$, C, $2.30 \mathrm{~m}$, and D, $2.60 \mathrm{~m}$ for the 2012 calibration period. 

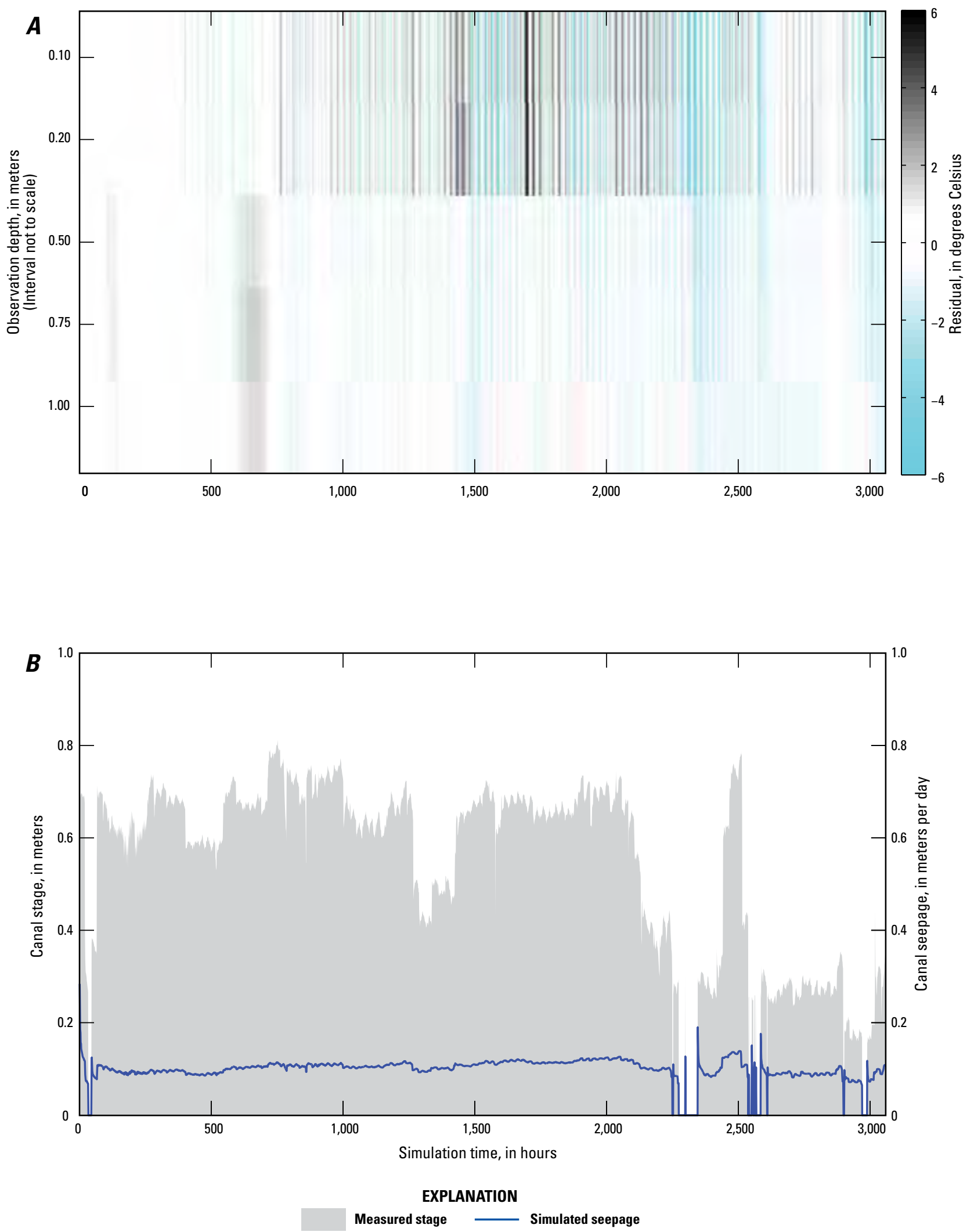

Figure 2A-6. Temperature residual for each depth below the canal at location $A, T 3$, and $B$, measured stage and simulated seepage for the 2012 prediction period. 


\section{Appendix 2A Temperature and Model Results for Fox Ditch 1.1, Mason Valley, Nevada}

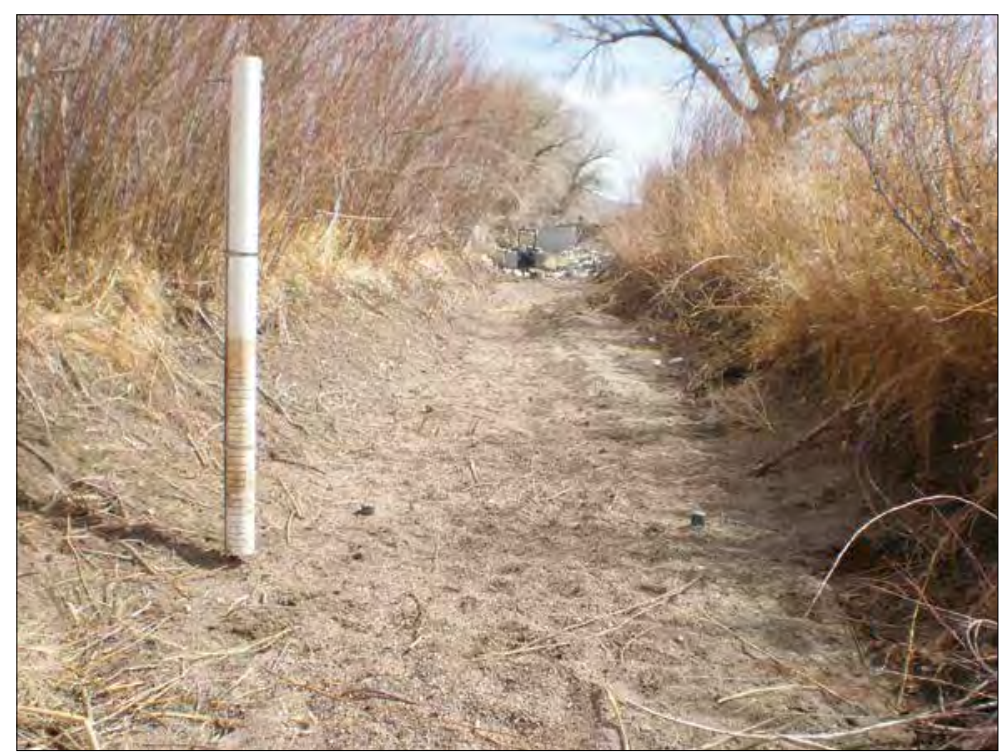

Figure 2A-7. Photograph of FOX DITCH 1.1 site, Yerrington, Nevada. Photograph taken by David W. Smith, U.S. Geological Survey, looking upstream on 3/13/2013.

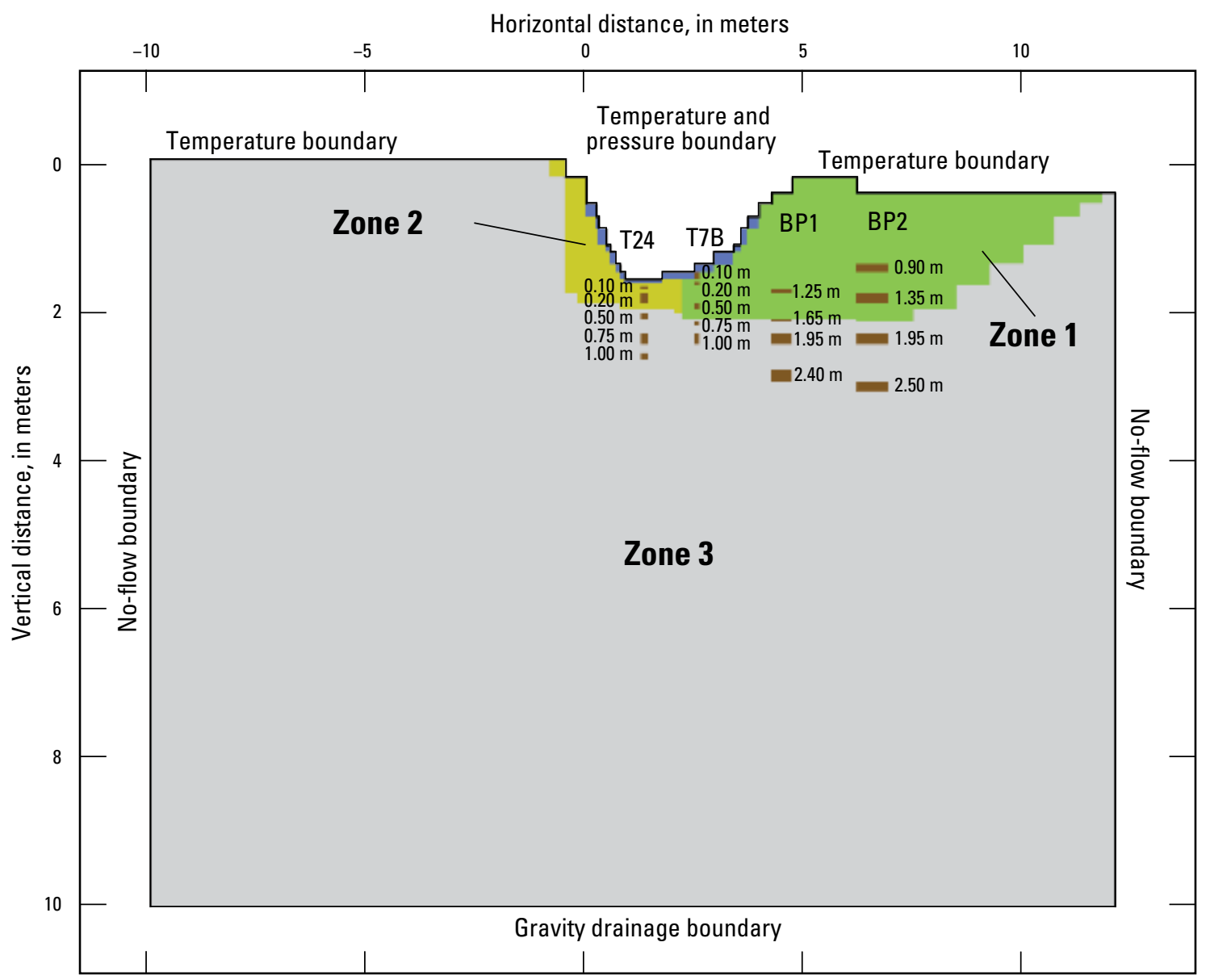

Figure 2A-8. Schematic cross section of two-dimensional VS2DH model of water and heat transport through canal-bed sediments at Fox Ditch 1.1 site with soil textural zones (Zones 1-3), locations of temperature observations below ground surface within the canal (T7B and T24) and along the banks (BP1 and BP2), and specified vertical and horizontal boundary conditions. 
$\boldsymbol{A}$

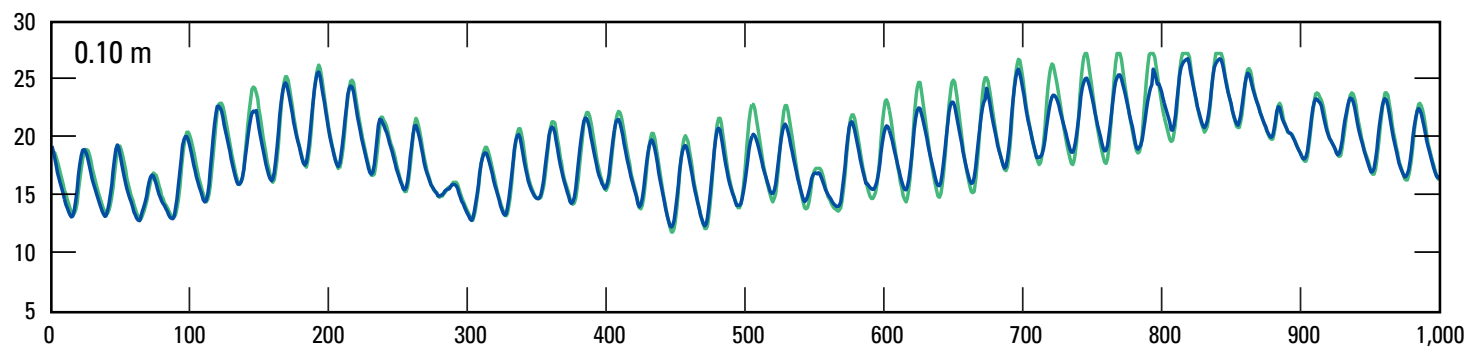

B

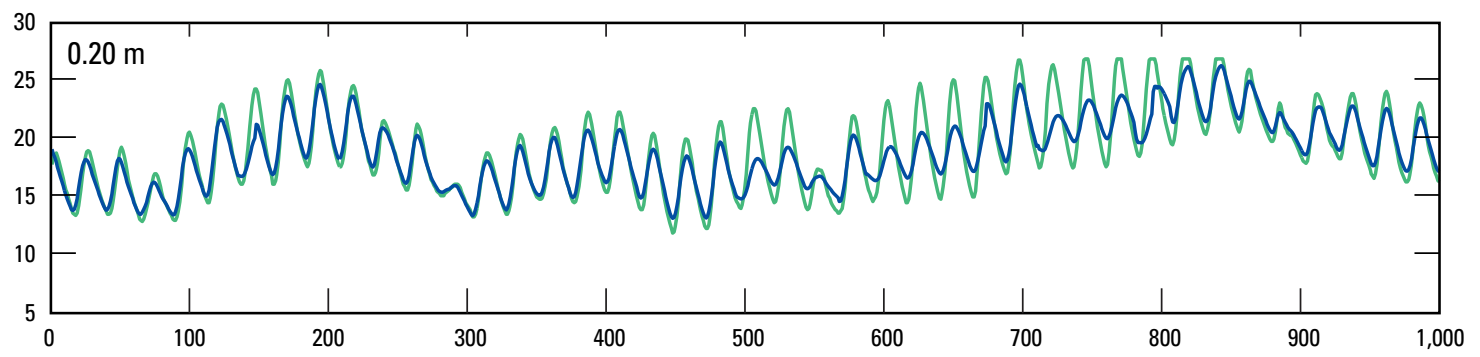

C

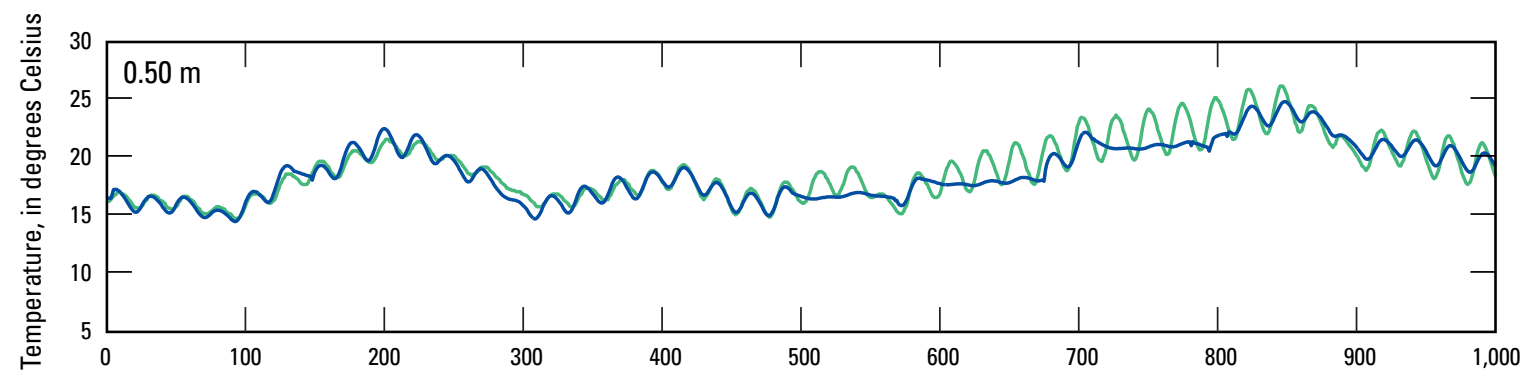

D

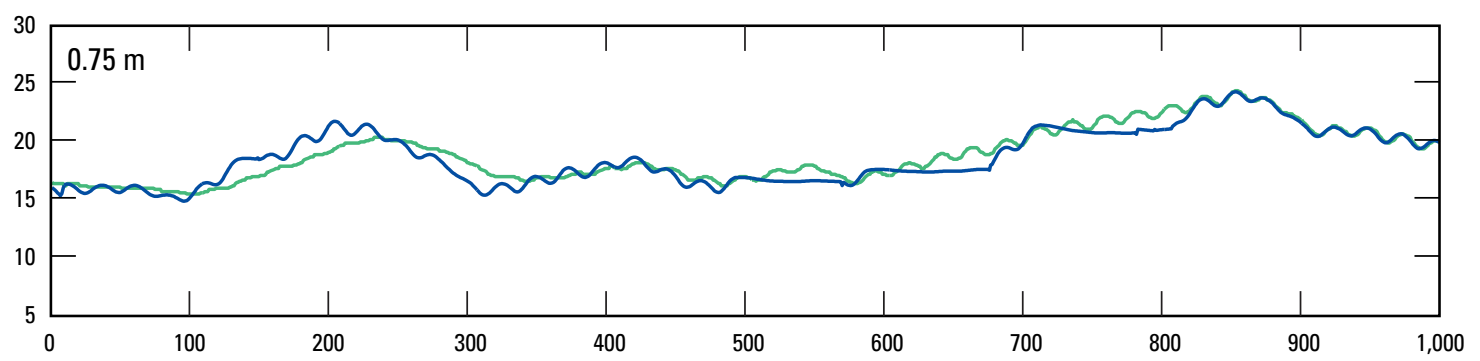

$\boldsymbol{E}$

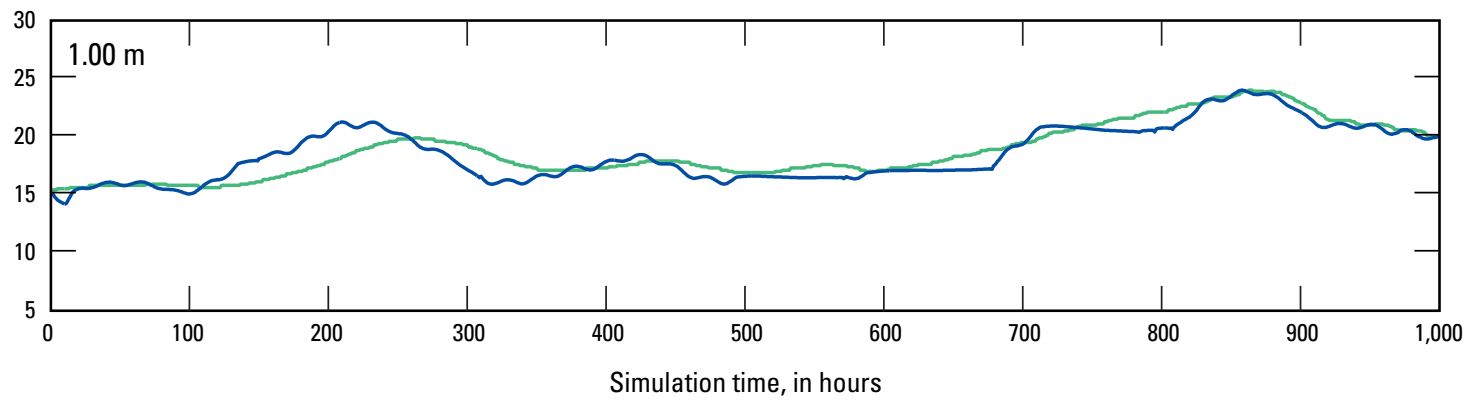

EXPLANATION

Measured

Simulated

Figure 2A-9. Measured and simulated thermographs for canal sediments for T7B at depths of $A, 0.10 \mathrm{~m}, \mathrm{~B}, 0.20 \mathrm{~m}, \mathrm{C}, 0.50 \mathrm{~m}, \mathrm{D}, 0.75 \mathrm{~m}$, and $\mathrm{E}, 1.0 \mathrm{~m}$ for the 2012 calibration period. 
A

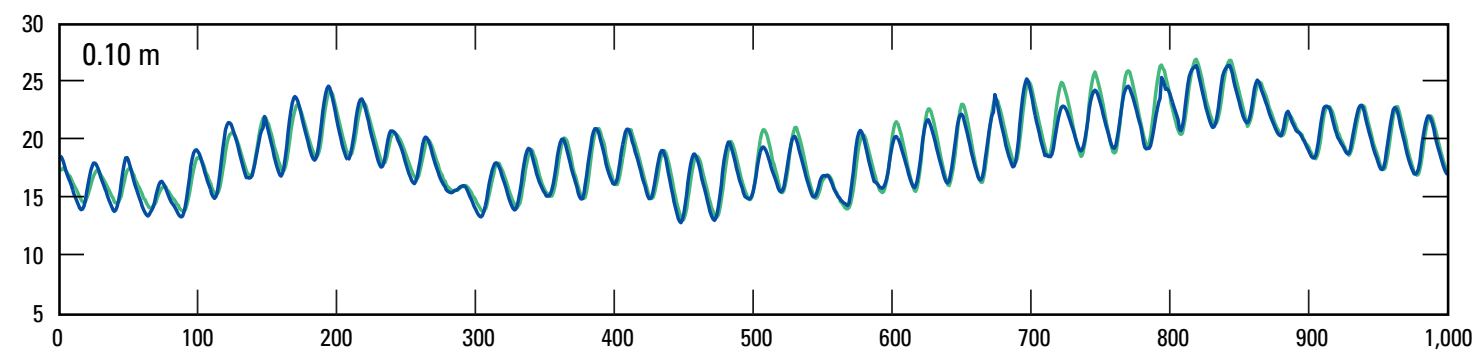

$\boldsymbol{B}$

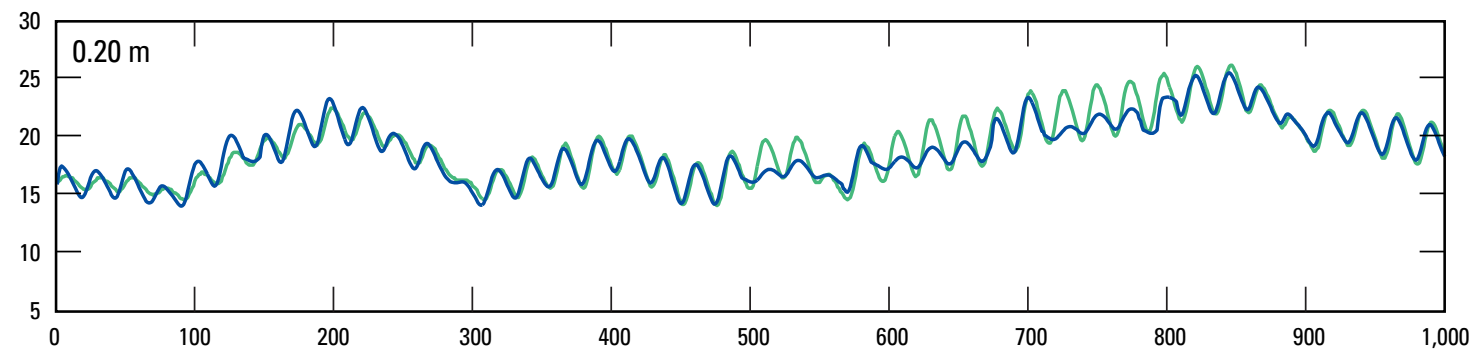

C
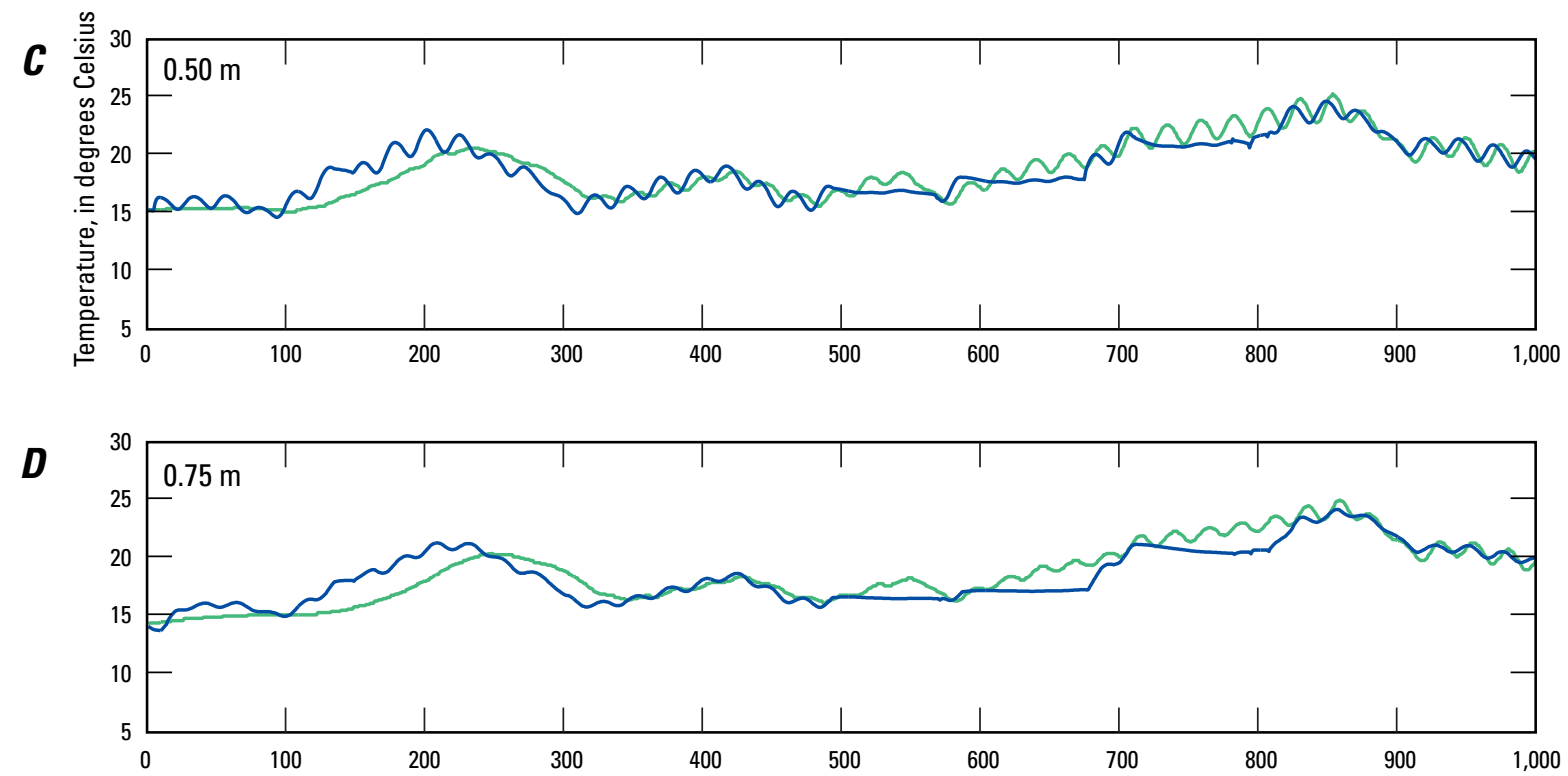

$\boldsymbol{E}$

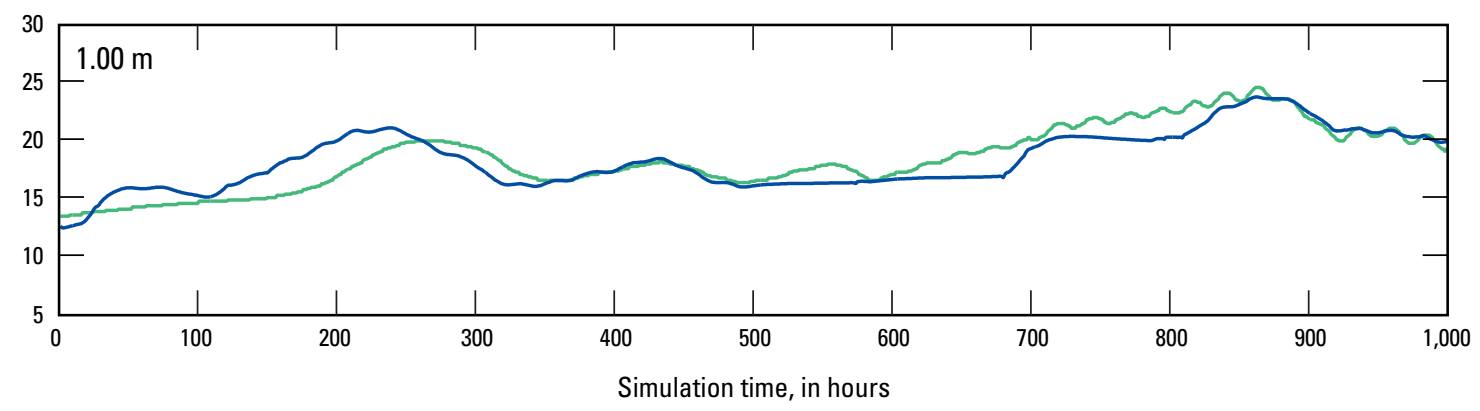

EXPLANATION

Measured

- Simulated

Figure 2A-10. Measured and simulated thermographs for canal sediments for T24 at depths of $A, 0.10 \mathrm{~m}, \mathrm{~B}, 0.20 \mathrm{~m}, \mathrm{C}, 0.50 \mathrm{~m}, \mathrm{D}, 0.75 \mathrm{~m}$, and $\mathrm{E}, 1.0 \mathrm{~m}$ for the 2013 calibration period. 

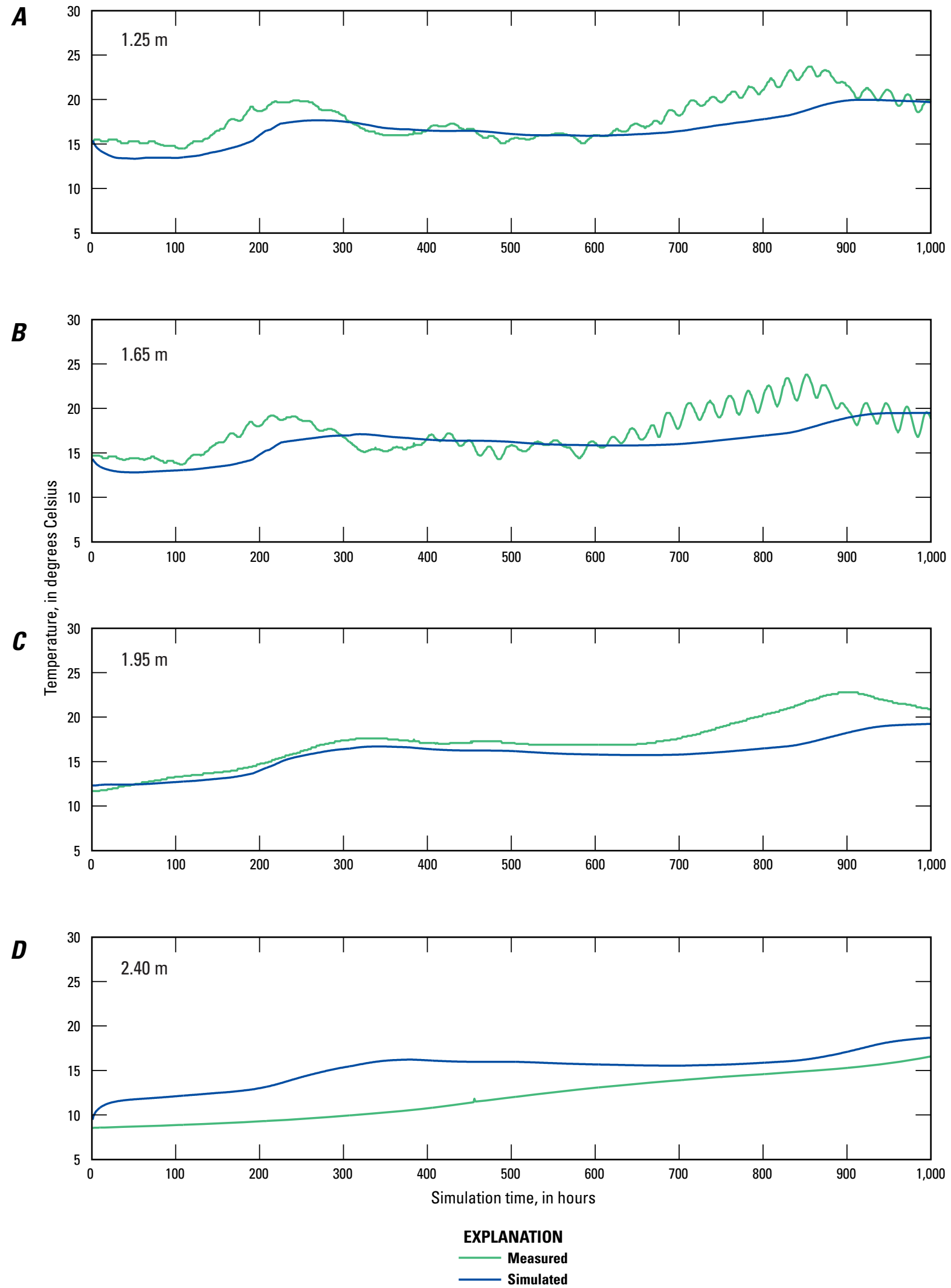

Figure 2A-11. Measured and simulated thermographs for Bank Piezometer 1 (BP1) observations at depths of $A, 1.25 \mathrm{~m}, B, 1.65 \mathrm{~m}$, $\mathrm{C}, 1.95 \mathrm{~m}$, and $\mathrm{D}, 2.40 \mathrm{~m}$ for the 2013 calibration period. 

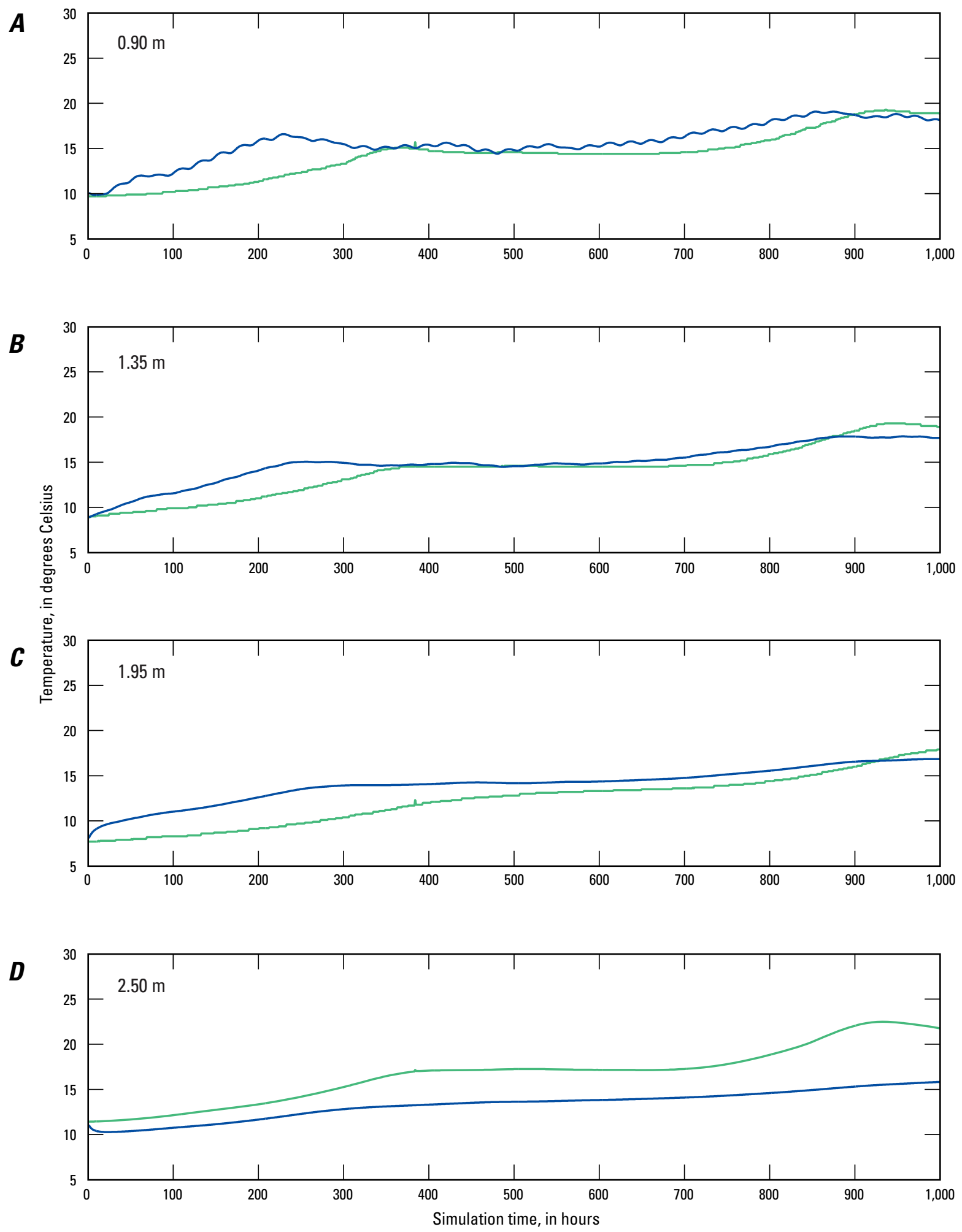

EXPLANATION

Measured

Simulated

Figure 2A-12. Measured and simulated thermographs for Bank Piezometer 2 (BP2) observations at depths of $A, 0.90 \mathrm{~m}, B, 1.35 \mathrm{~m}$, C, $1.95 \mathrm{~m}$, and D, $2.50 \mathrm{~m}$ for the 2013 calibration period. 

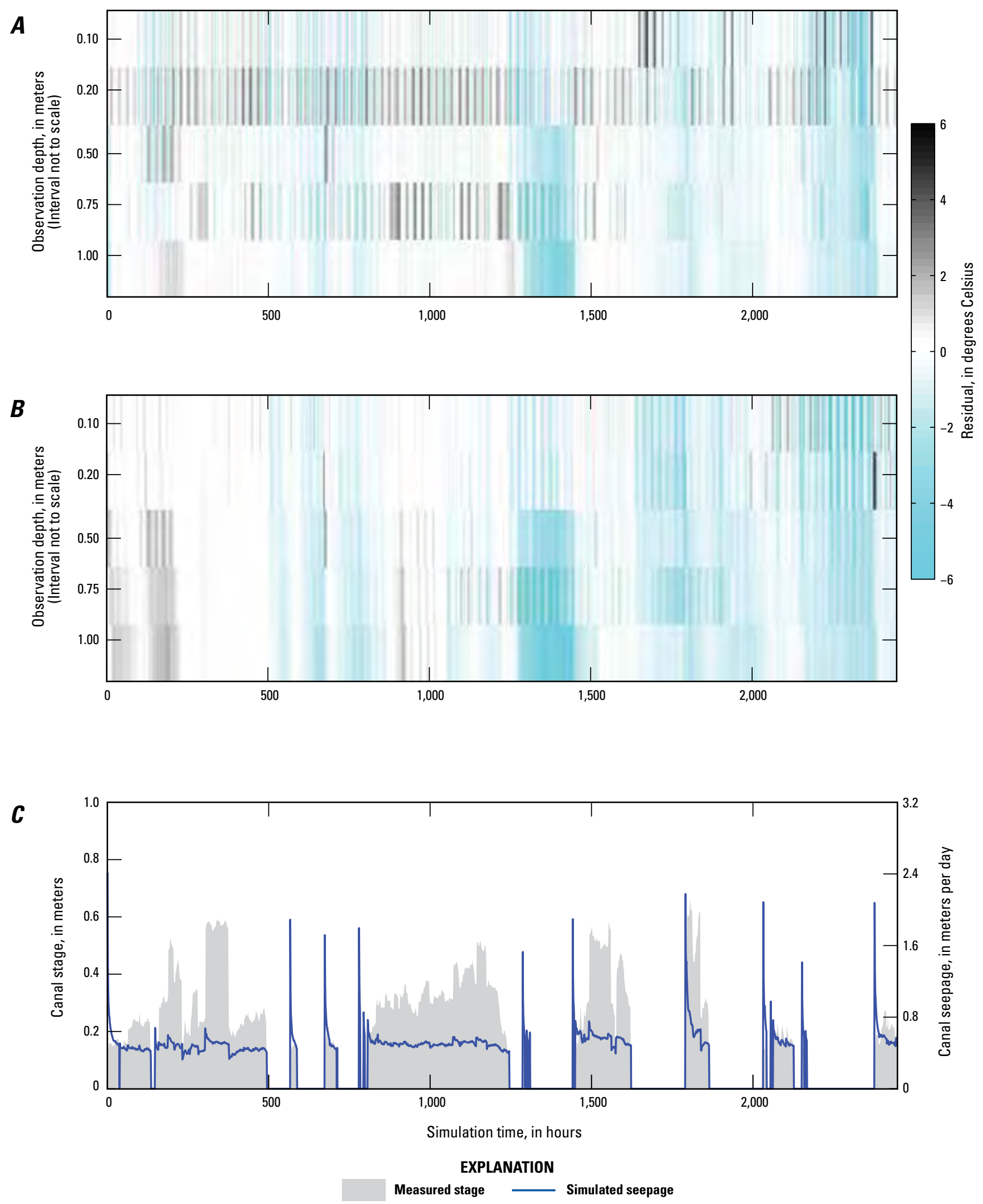

Figure 2A-13. Temperature residual for each depth below the canal at location $A, T 7 B$ and $B, T 24$, and C, measured stage and simulated seepage for the 2013 prediction period. 


\section{Appendix 2A Temperature and Model Results for Fox Ditch 2, Mason Valley, Nevada}

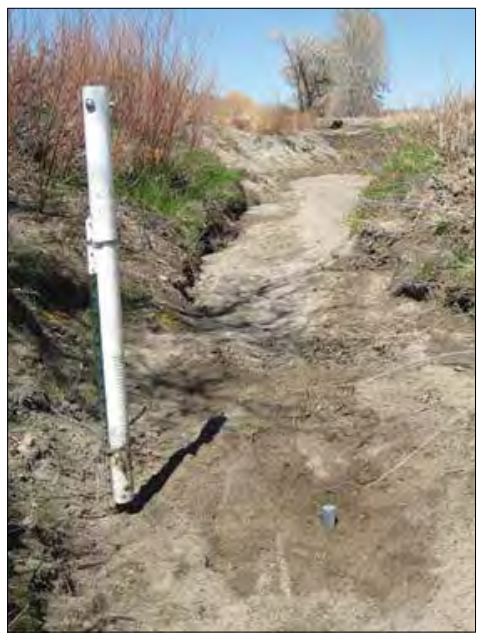

Figure 2A-14. Photograph of FOX DITCH 2 site, Yerrington, Nevada. Photograph taken by David W. Smith, U.S. Geological Survey, looking downstream on 4/18/2013.

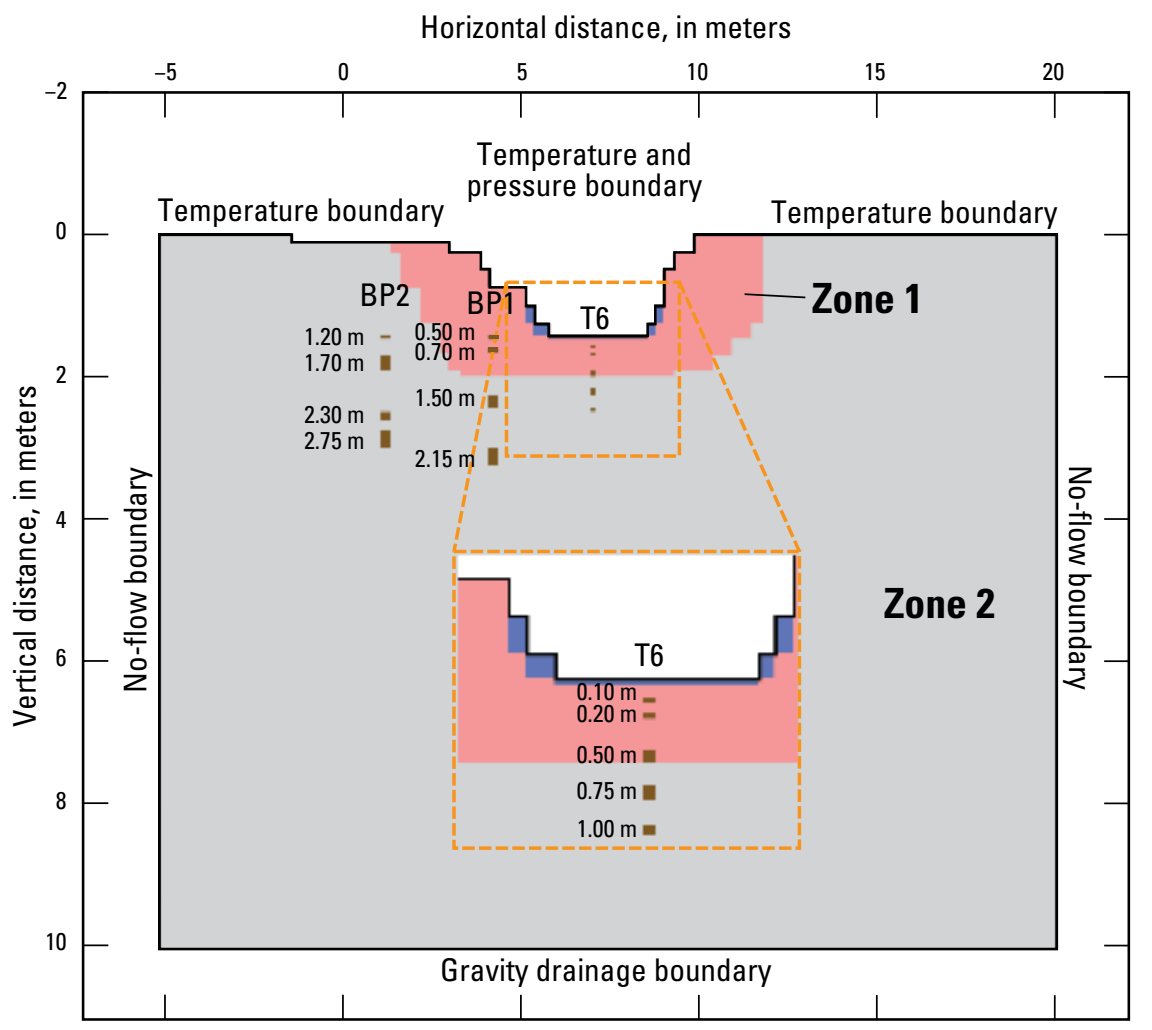

Figure 2A-15. Schematic cross section of two-dimensional VS2DH model of water and heat transport through canal-bed sediments at FOX DITCH 2 site with soil textural zones (Zones 1-2), locations of temperature observations below ground surface within the canal (T6) and along the banks (BP1 and BP2), and specified vertical and horizontal boundary conditions. 
$\boldsymbol{A}$

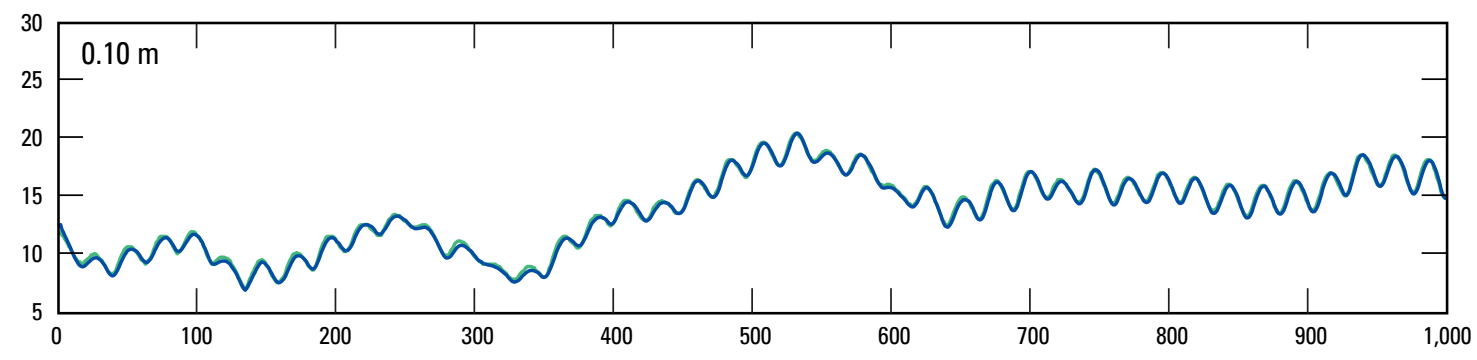

B

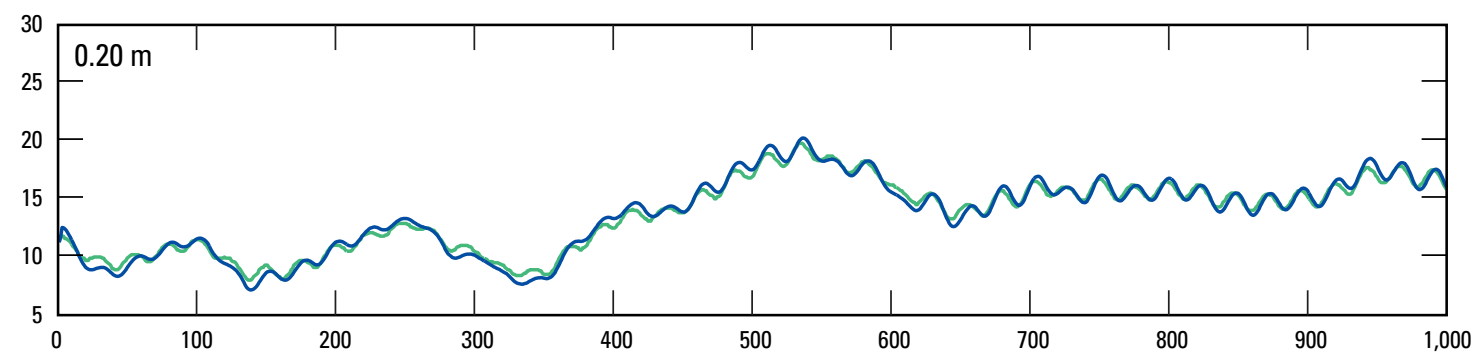

C

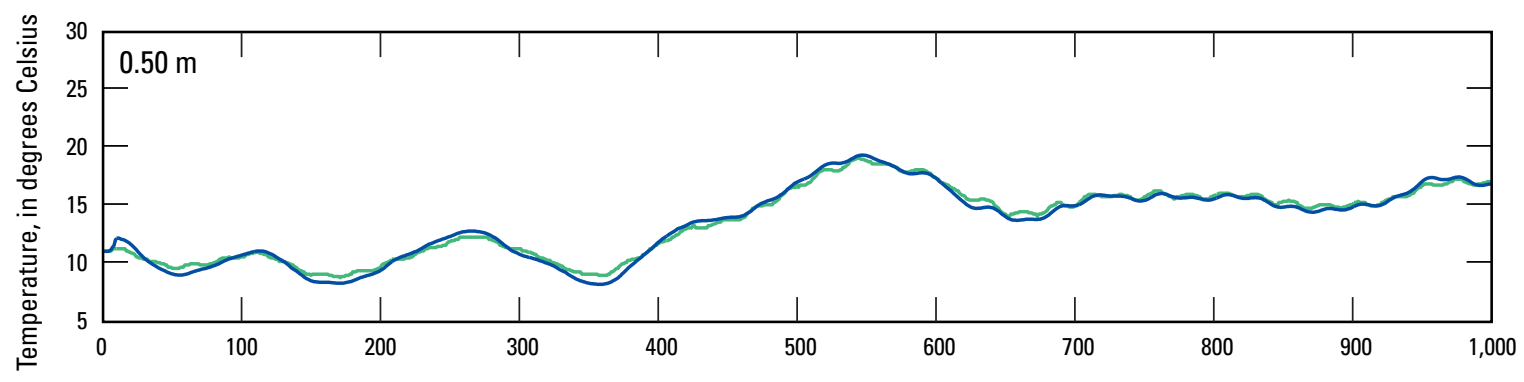

D

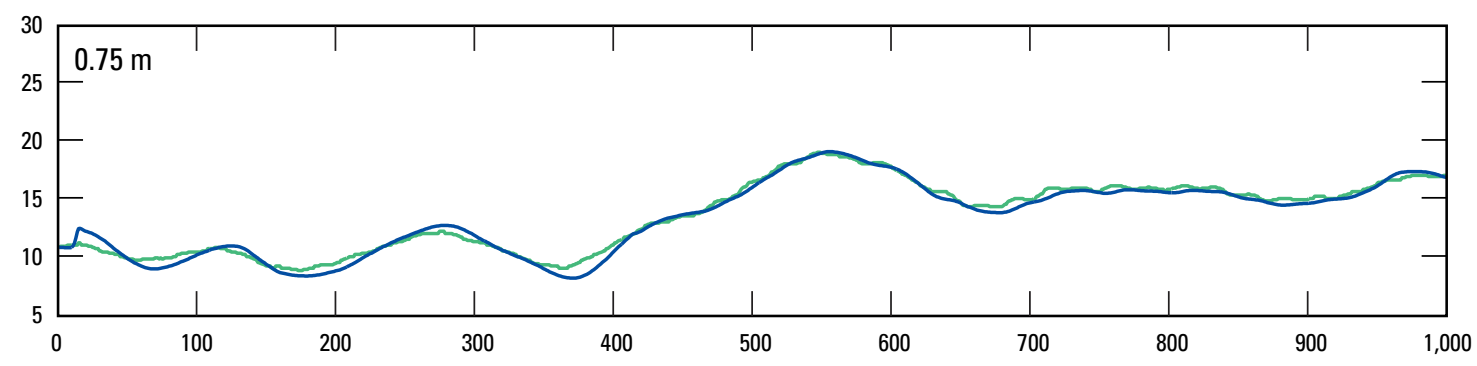

$\boldsymbol{E}$

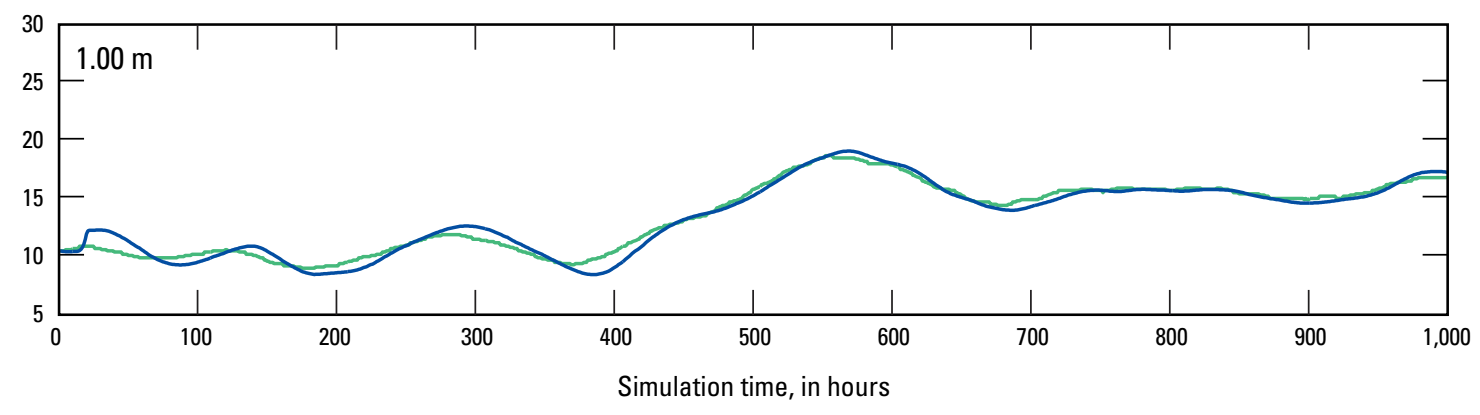

\section{EXPLANATION}

Measured

Simulated

Figure 2A-16. Measured and simulated thermographs for canal sediments for T6 at depths of $A, 0.10 \mathrm{~m}, \mathrm{~B}, 0.20 \mathrm{~m}, \mathrm{C}, 0.50 \mathrm{~m}, \mathrm{D}, 0.75 \mathrm{~m}$, and $\mathrm{E}, 1.0 \mathrm{~m}$ for the 2012 calibration period. 

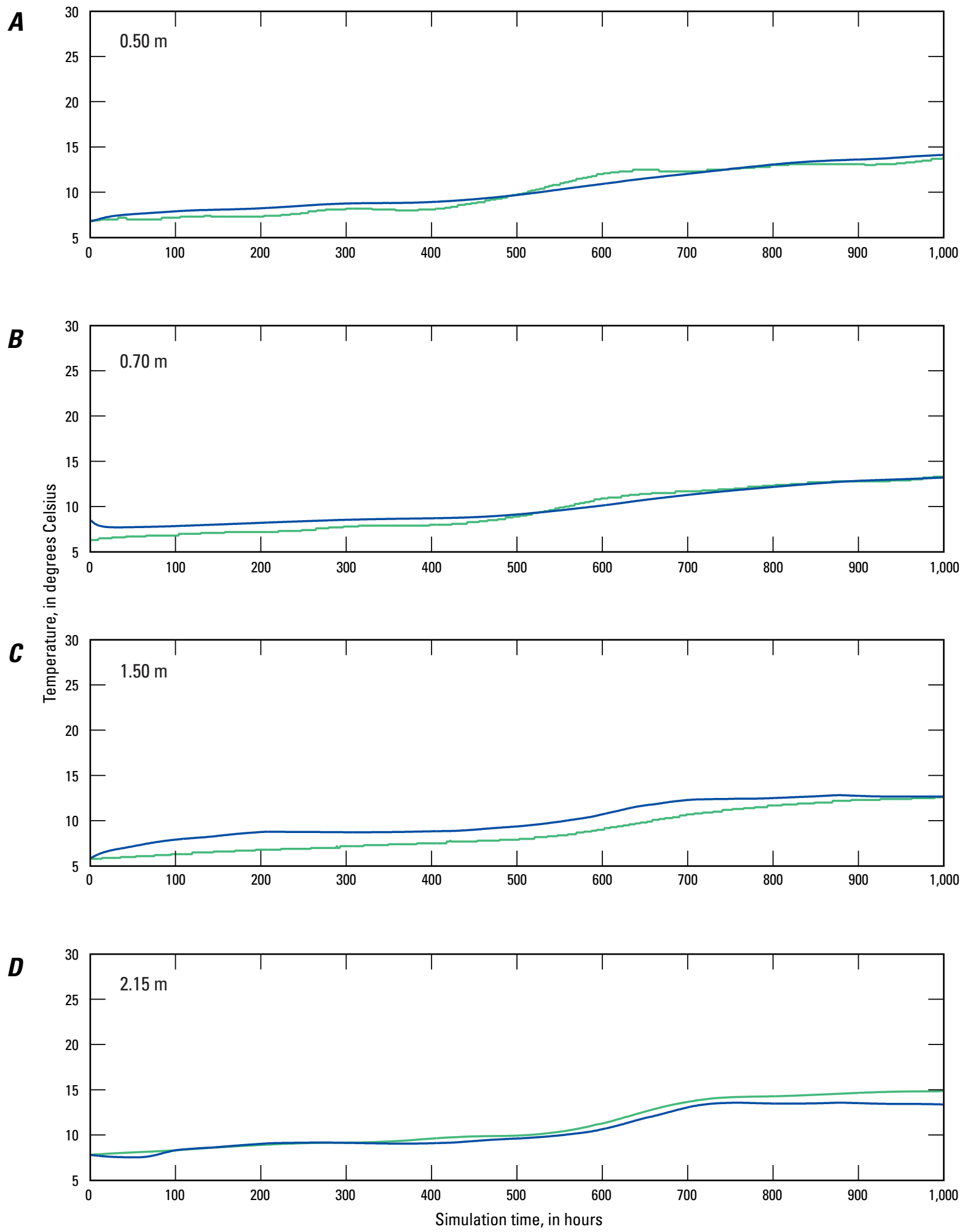

EXPLANATION

Measured

Simulated

Figure 2A-17. Measured and simulated thermographs for Bank Piezometer 1 (BP1) observations at depths of $A, 0.50 \mathrm{~m}, B, 0.70 \mathrm{~m}$, C, $1.50 \mathrm{~m}$, and D, $2.15 \mathrm{~m}$ for the 2012 calibration period. 

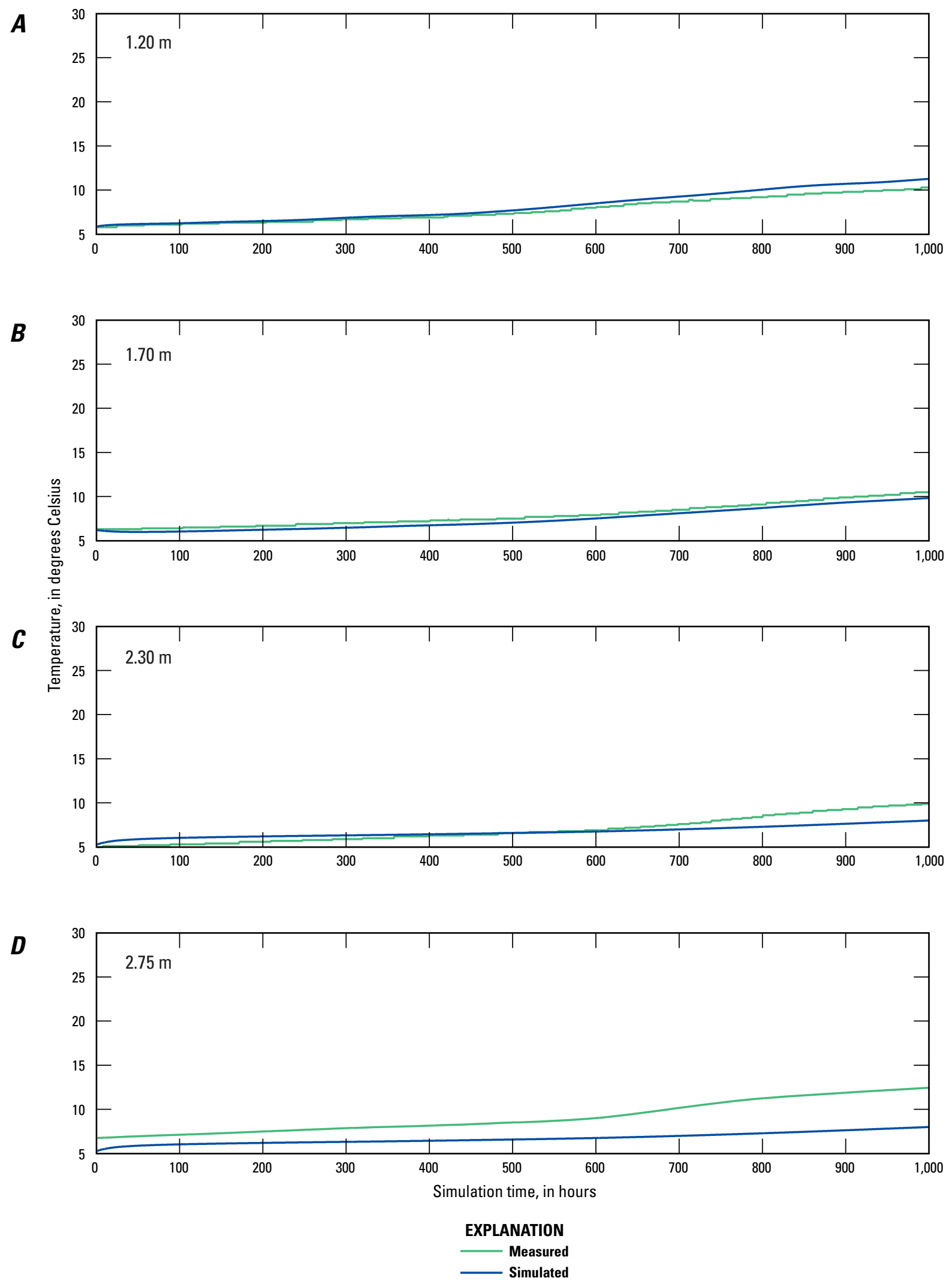

Figure 2A-18. Measured and simulated thermographs for Bank Piezometer 2 (BP2) observations at depths of $A, 1.20 \mathrm{~m}, \mathrm{~B}, 1.70 \mathrm{~m}$, $\mathrm{C}, 2.30 \mathrm{~m}$, and $\mathrm{D}, 2.75 \mathrm{~m}$ for the 2012 calibration period. 

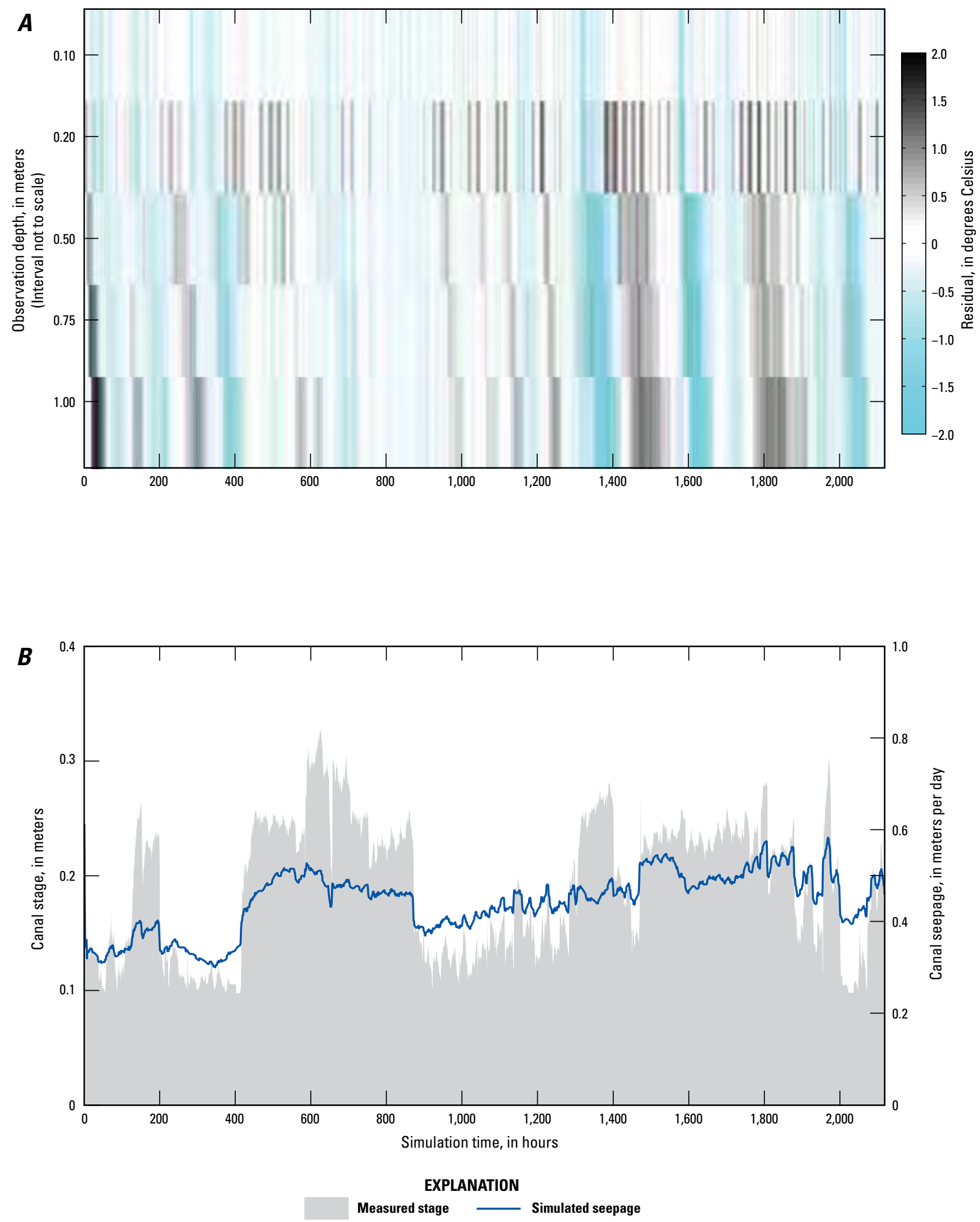

Figure 2A-19. Temperature residual for each depth below the canal at location $A, T 6$, and $B$, measured stage and simulated seepage for the 2012 prediction period. 

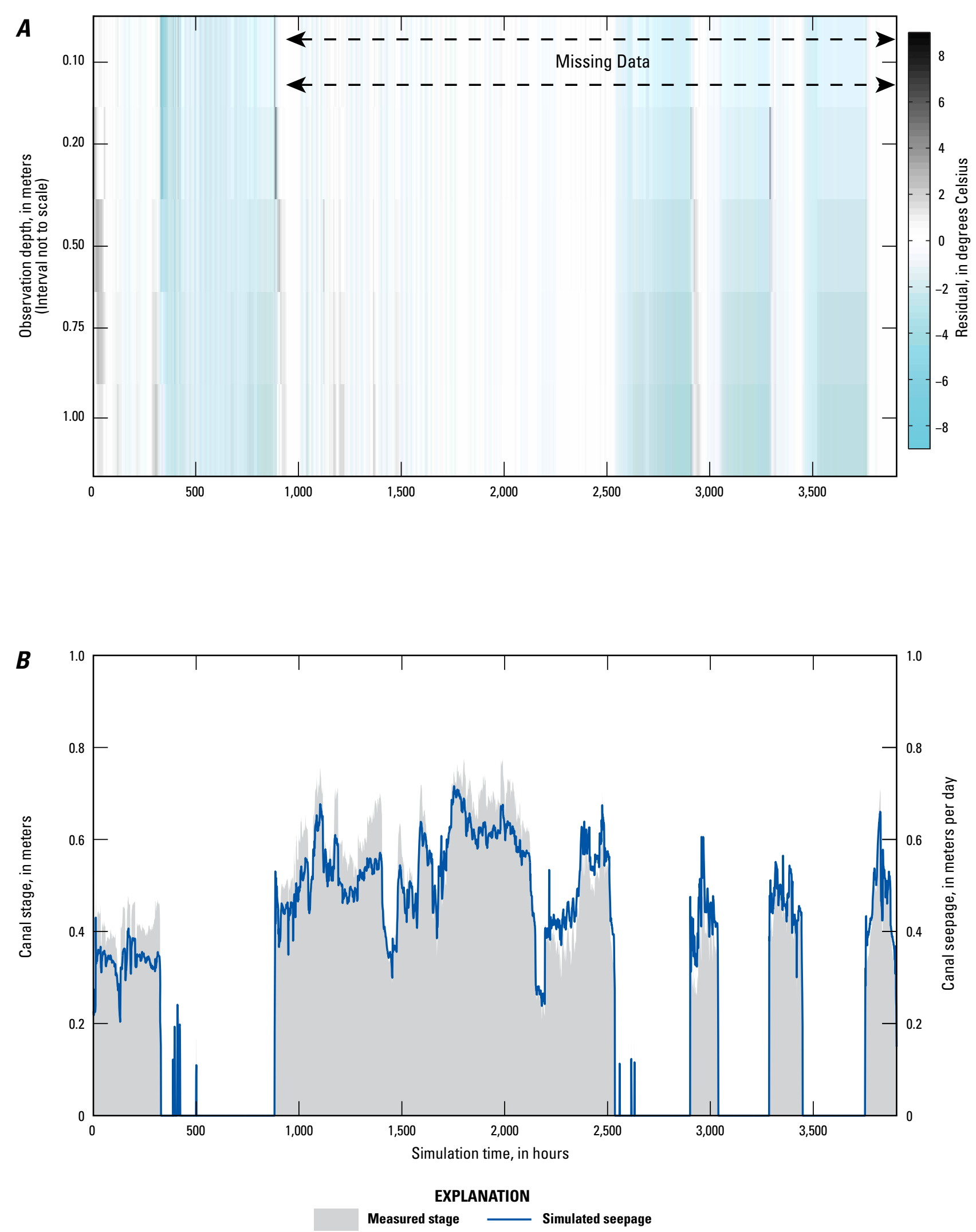

Figure 2A-20. Temperature residual for each depth below the canal at location $A, T 6$, and $B$, measured stage and simulated seepage for the 2013 prediction period. 


\section{Appendix 2B Temperature and Model Results for Mickey Ditch 1, Mason Valley, Nevada}

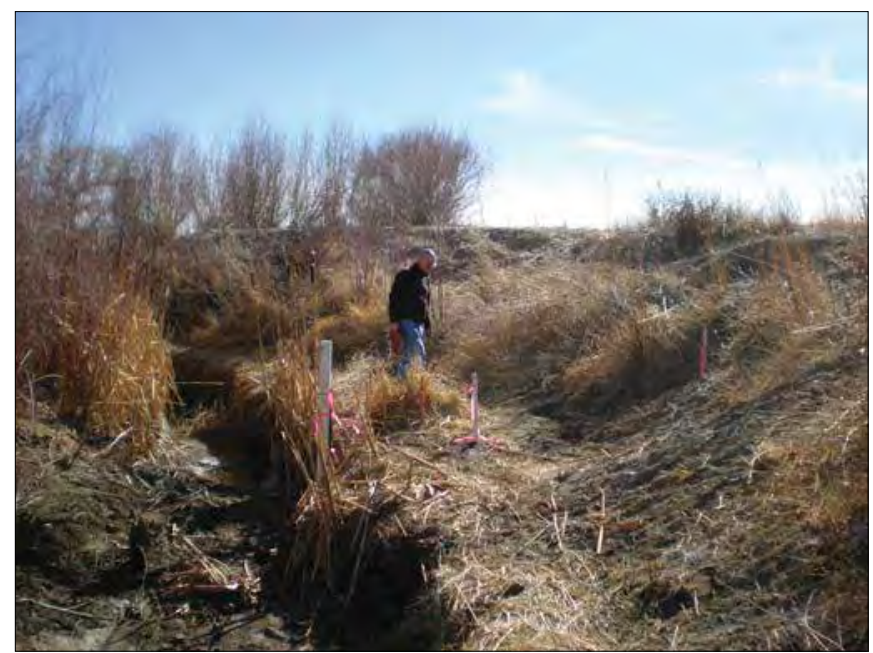

Figure 2B-1. Photograph of MICKEY DITCH 1 site, Yerrington, Nevada. Photograph taken by David W. Smith, U.S. Geological Survey, looking downstream on 2/22/2012.

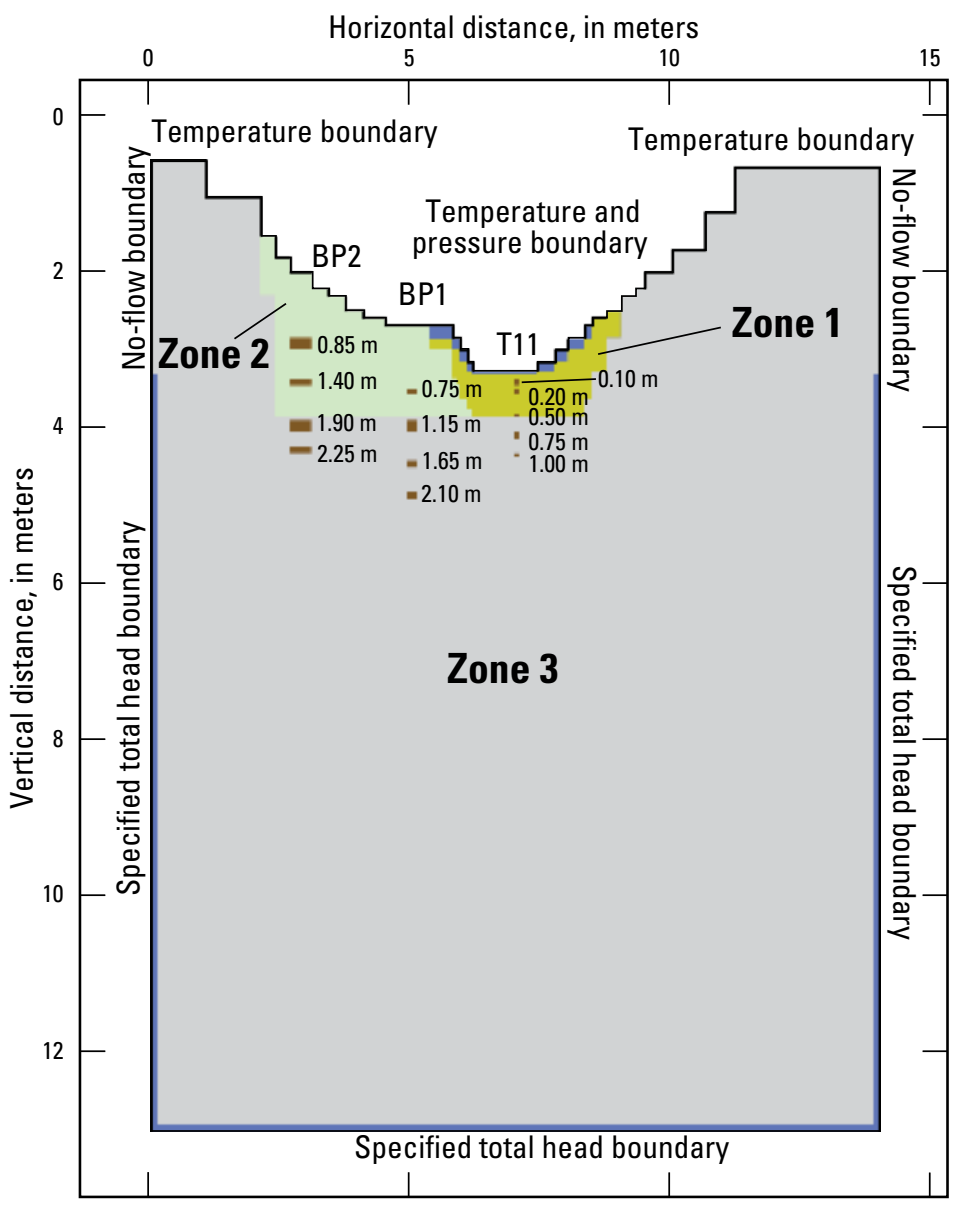

Figure 2B-2. Schematic cross section of two-dimensional VS2DH model of water and heat transport through canal-bed sediments at MICKEY DITCH 1 site with soil textural zones (Zones 1-3), locations of temperature observations below ground surface within the canal (T11) and along the banks (BP1 and BP2), and specified vertical and horizontal boundary conditions. 
$\boldsymbol{A}$

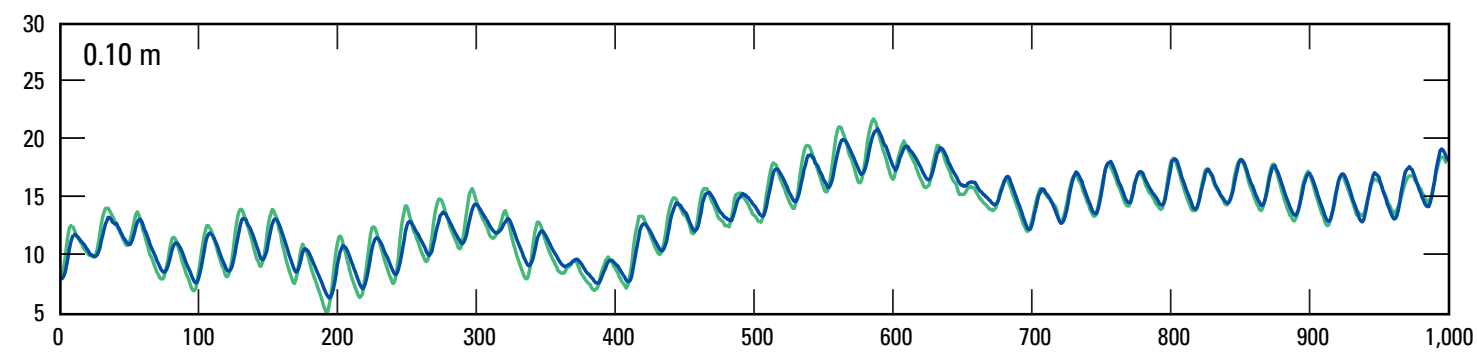

B

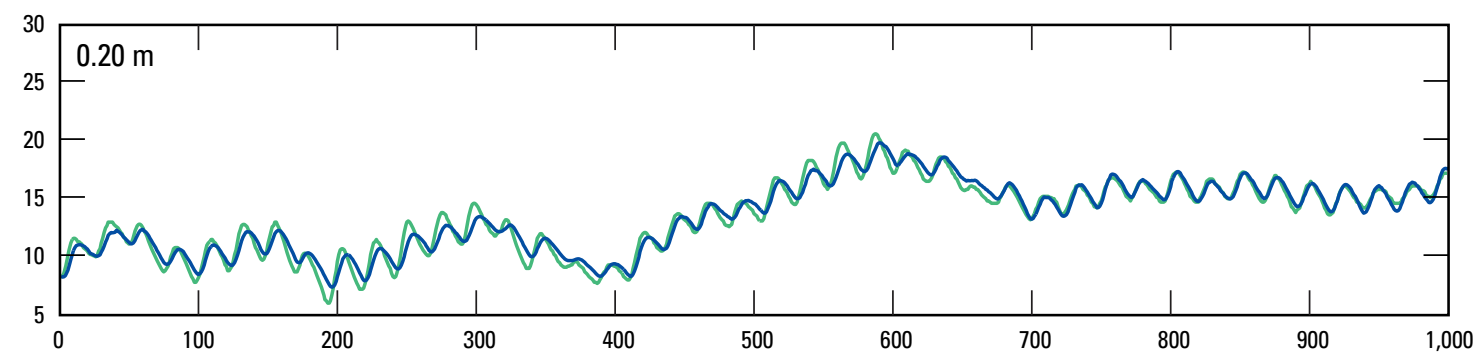

c

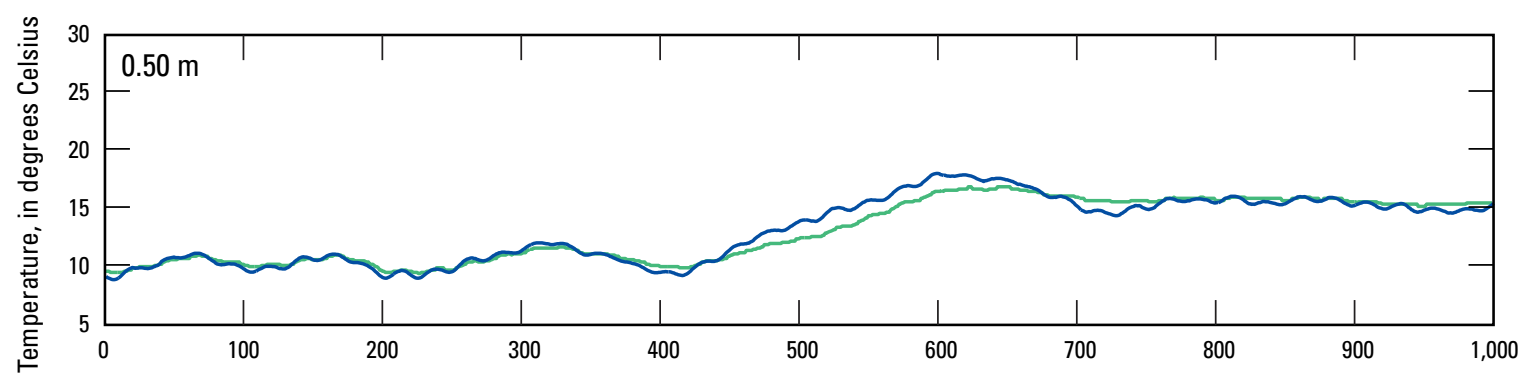

D

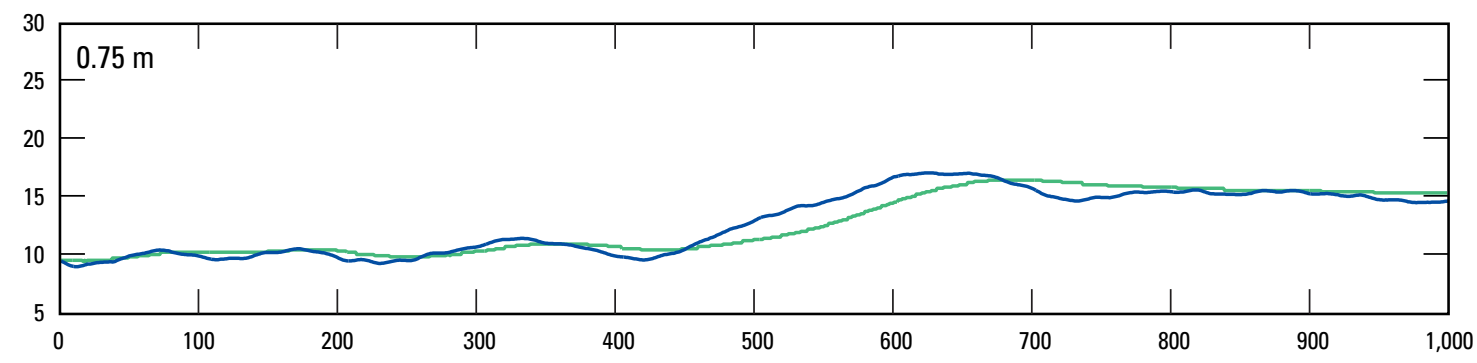

E

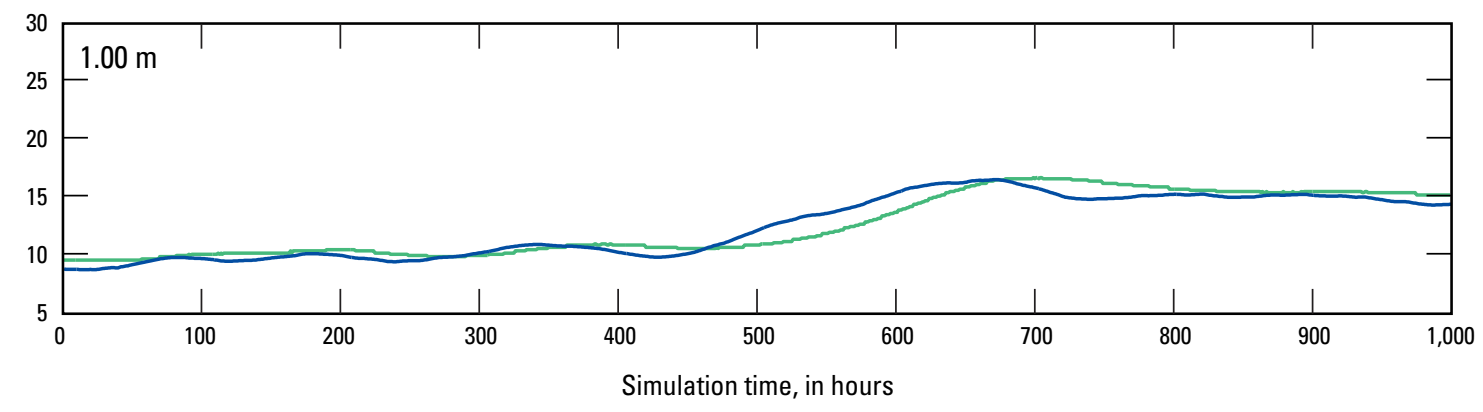

\section{EXPLANATION}

Measured

Simulated

Figure 2B-3. Measured and simulated thermographs for canal sediments for T11 at depths of A, $0.10 \mathrm{~m}, \mathrm{~B}, 0.20 \mathrm{~m}, \mathrm{C}, 0.50 \mathrm{~m}, \mathrm{D}, 0.75 \mathrm{~m}$, and $\mathrm{E}, 1.0 \mathrm{~m}$ for the 2012 calibration period. 

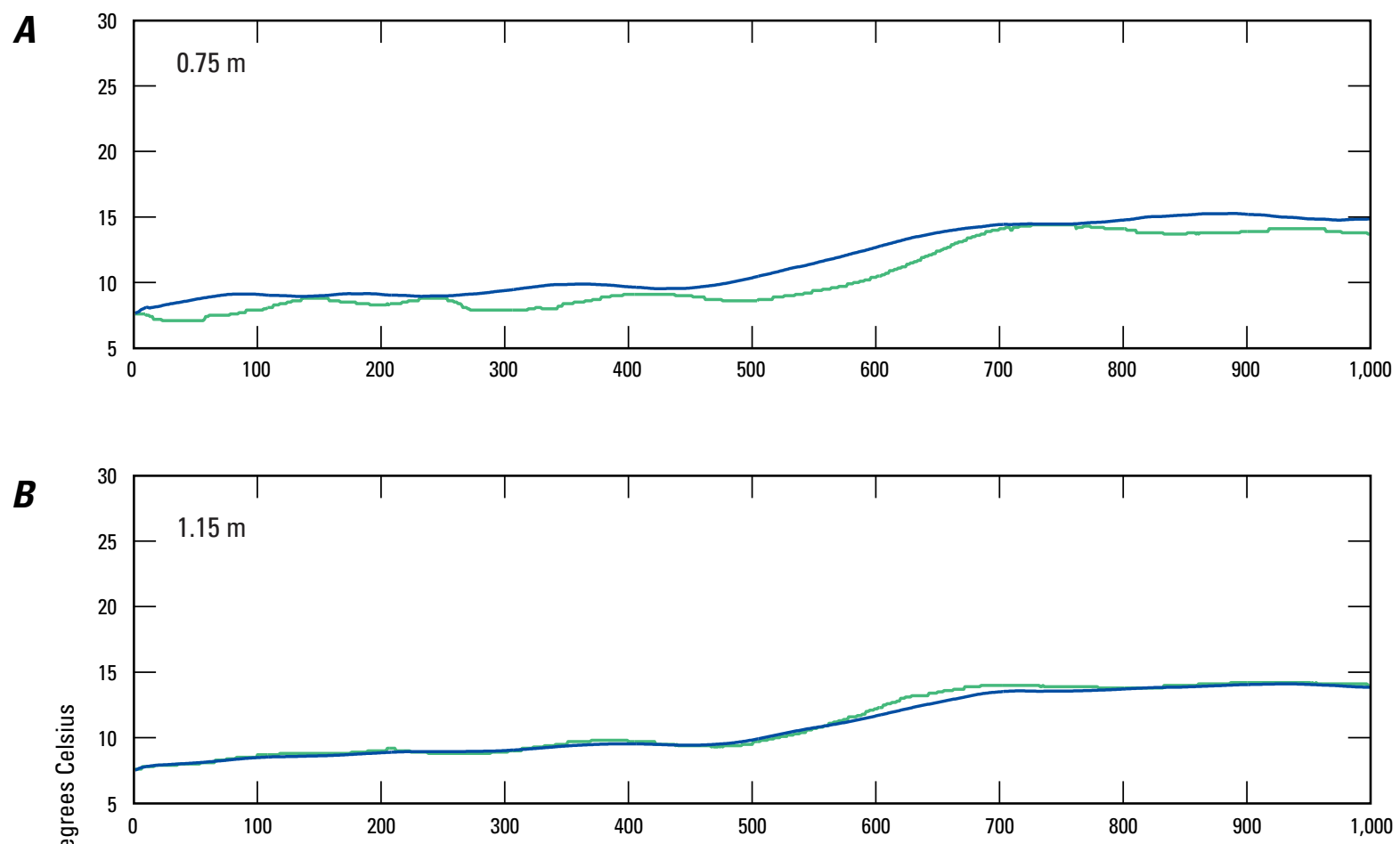

$\boldsymbol{C}$
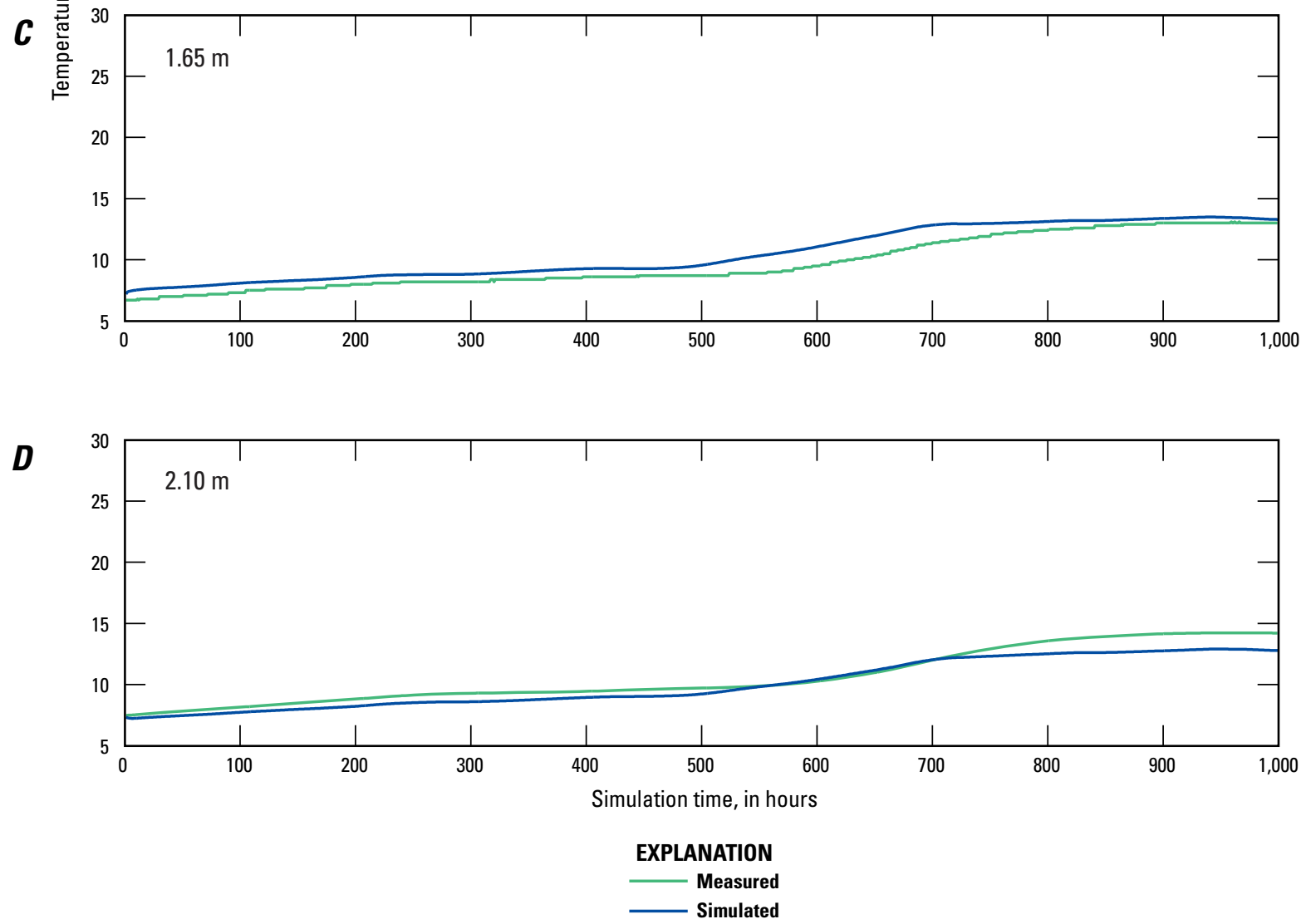

Figure 2B-4. Measured and simulated thermographs for Bank Piezometer 1 (BP1) observations at depths of $A, 0.75 \mathrm{~m}, \mathrm{~B}, 1.15 \mathrm{~m}$, $\mathrm{C}, 1.65 \mathrm{~m}$, and $\mathrm{D}, 2.10 \mathrm{~m}$ for the 2012 calibration period. 

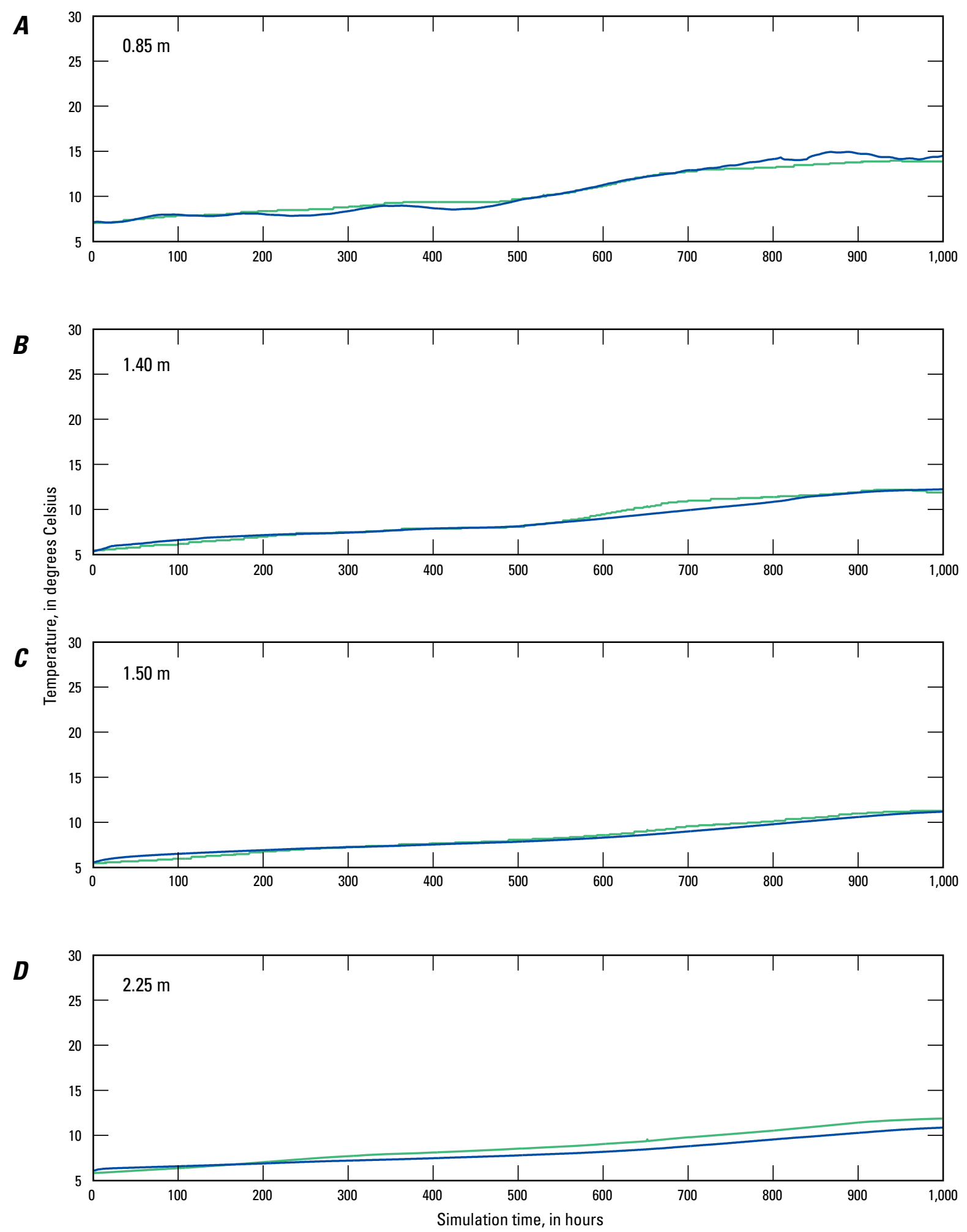

EXPLANATION

Measured

Figure 2B-5. Measured and simulated thermographs for Bank Piezometer 2 (BP2) observations at depths of A, $0.85 \mathrm{~m}, B, 1.40 \mathrm{~m}$, $\mathrm{C}, 1.90 \mathrm{~m}$, and $\mathrm{D}, 2.25 \mathrm{~m}$ for the 2012 calibration period. 

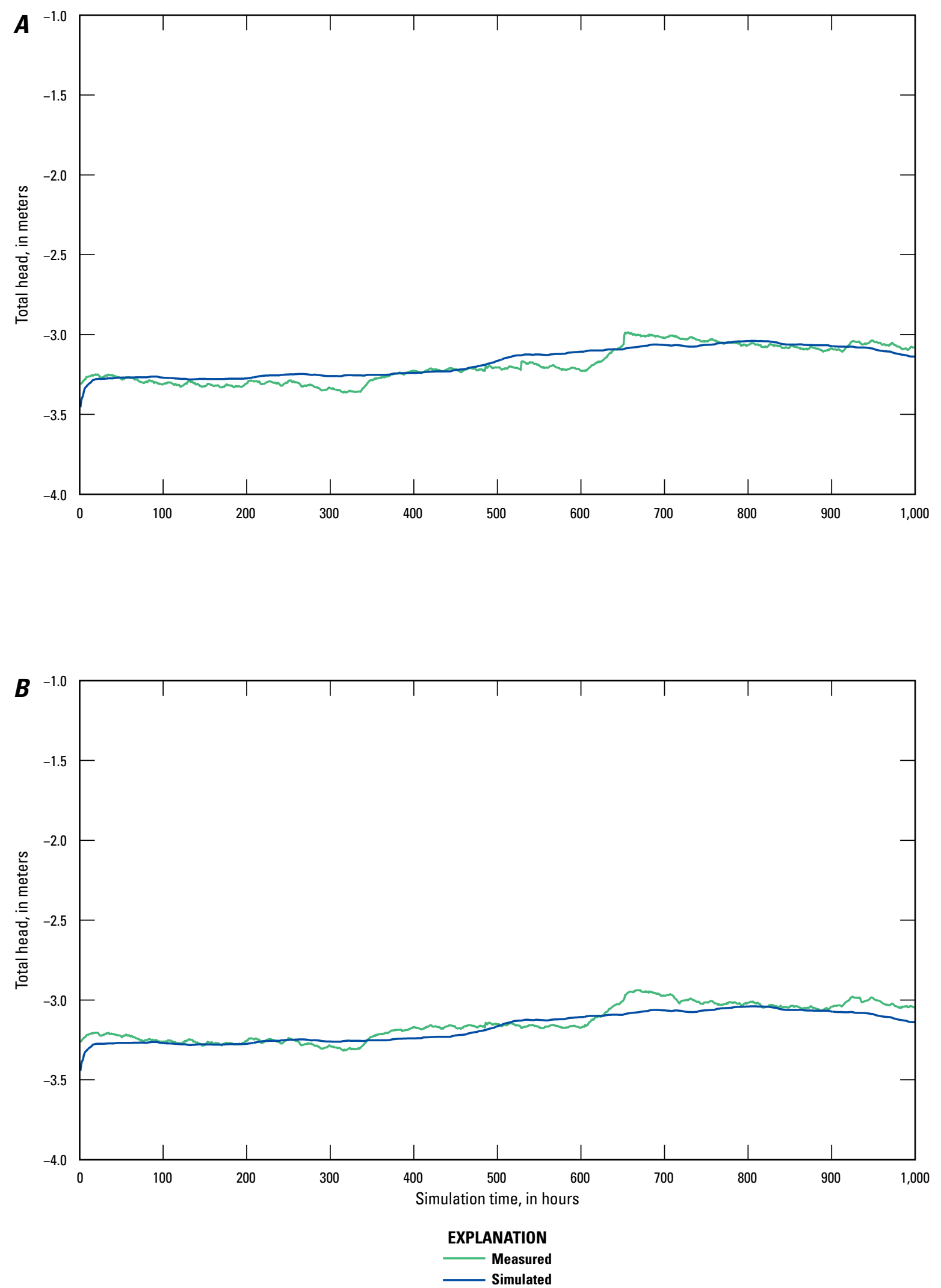

Figure 2B-6. Measured and simulated total head for Bank Piezometer (BP) observations at A, BP1 and B, BP2 for the 2012 calibration period. 

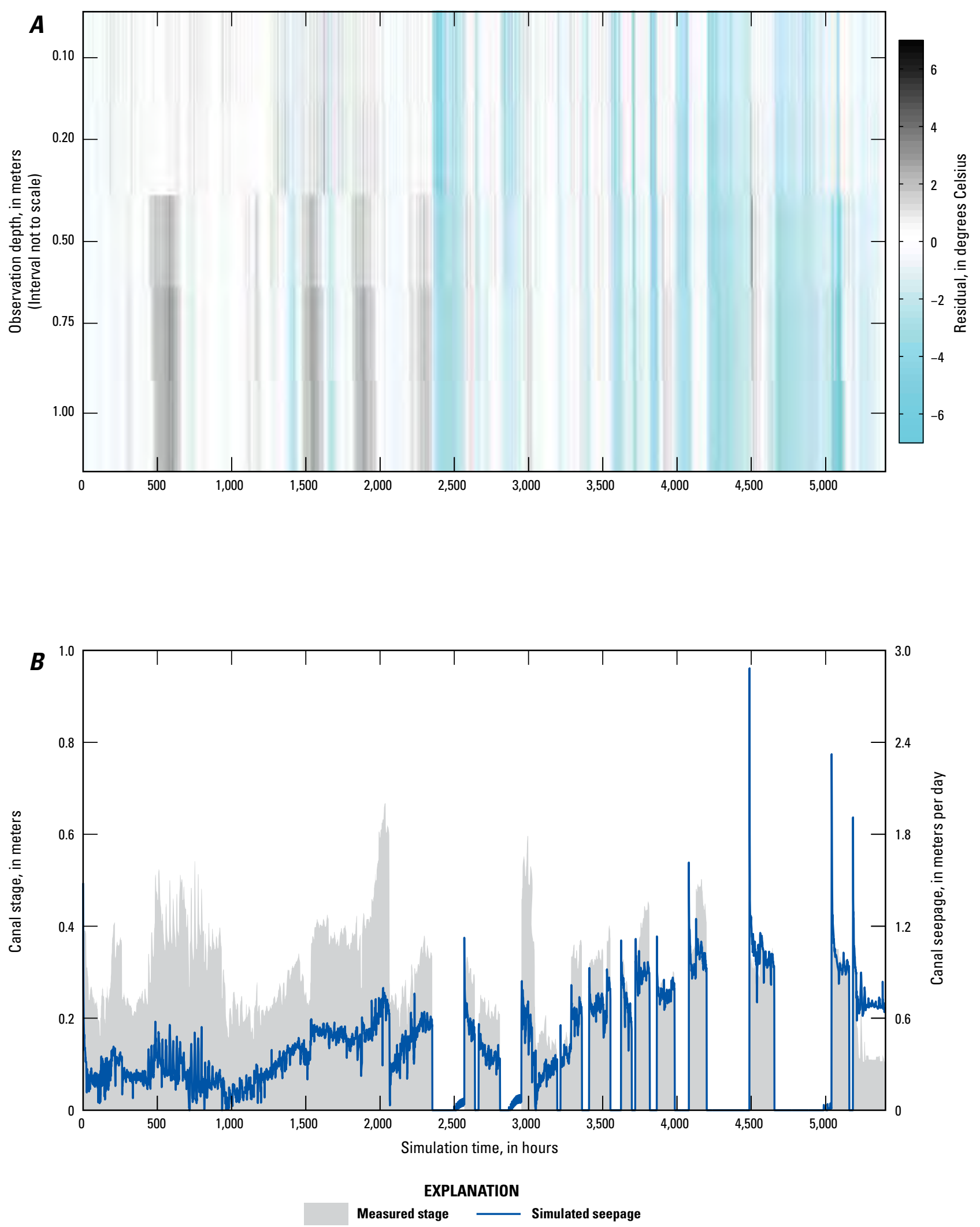

Figure 2B-7. Temperature residual for each depth below the canal at location $A, T 11$, and $B$, measured stage and simulated seepage for the 2012 prediction period. 

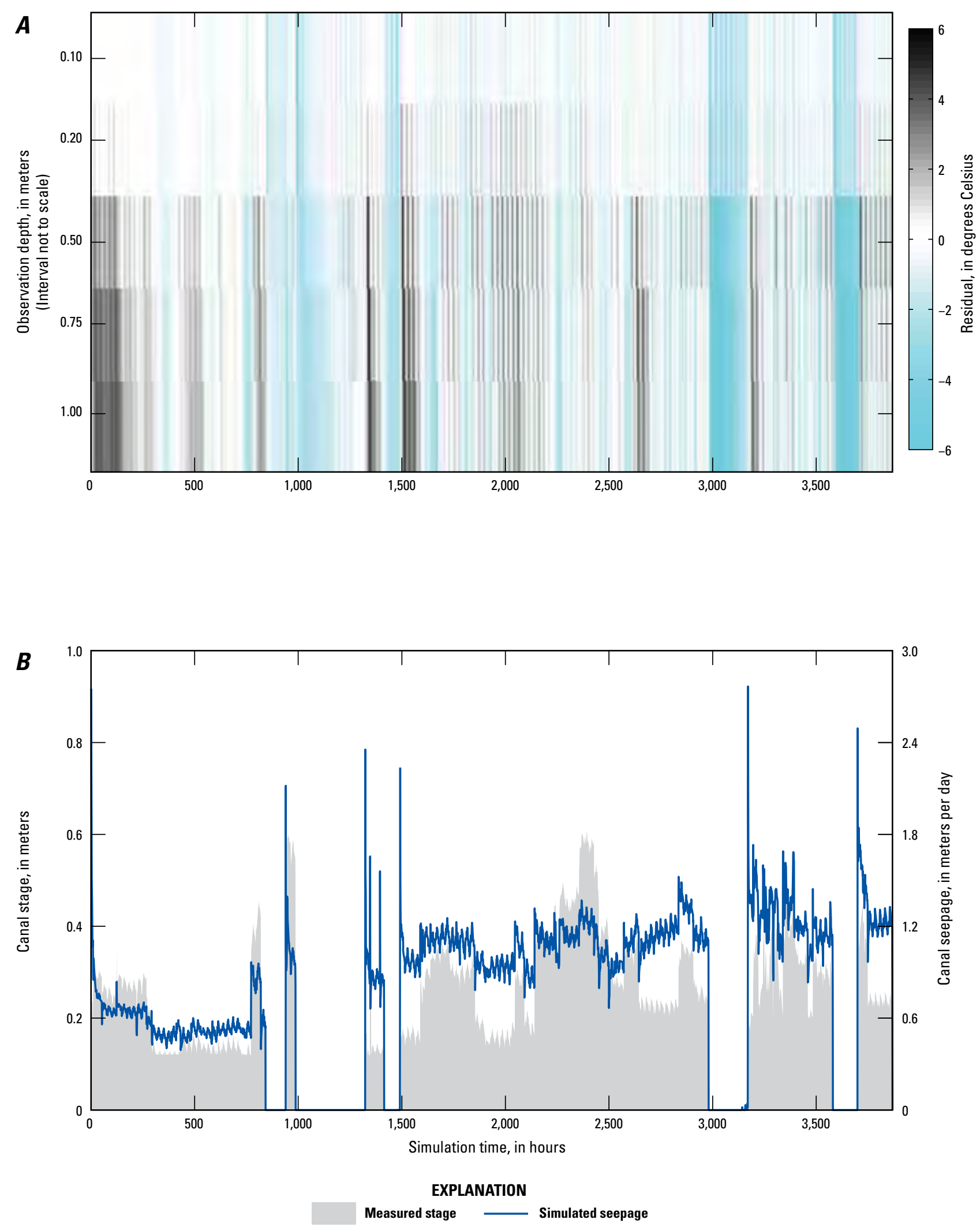

Figure 2B-8. Temperature residual for each depth below the canal at location $A, T 11$, and $B$, measured stage and simulated seepage for the 2013 prediction period. 


\section{Appendix 2B Temperature and Model Results for Mickey Ditch 1.1, Mason Valley, Nevada}

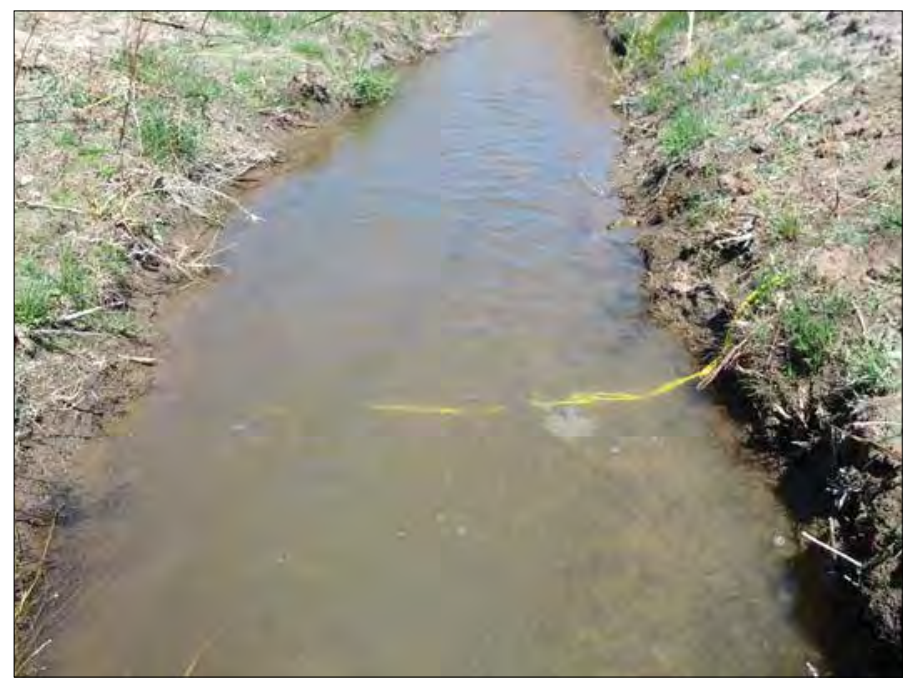

Figure 2B-9. Photograph of MICKEY DITCH 1.1 site, Yerrington, Nevada. Photograph taken by David W. Smith, U.S. Geological Survey, looking downstream on 4/9/2013.

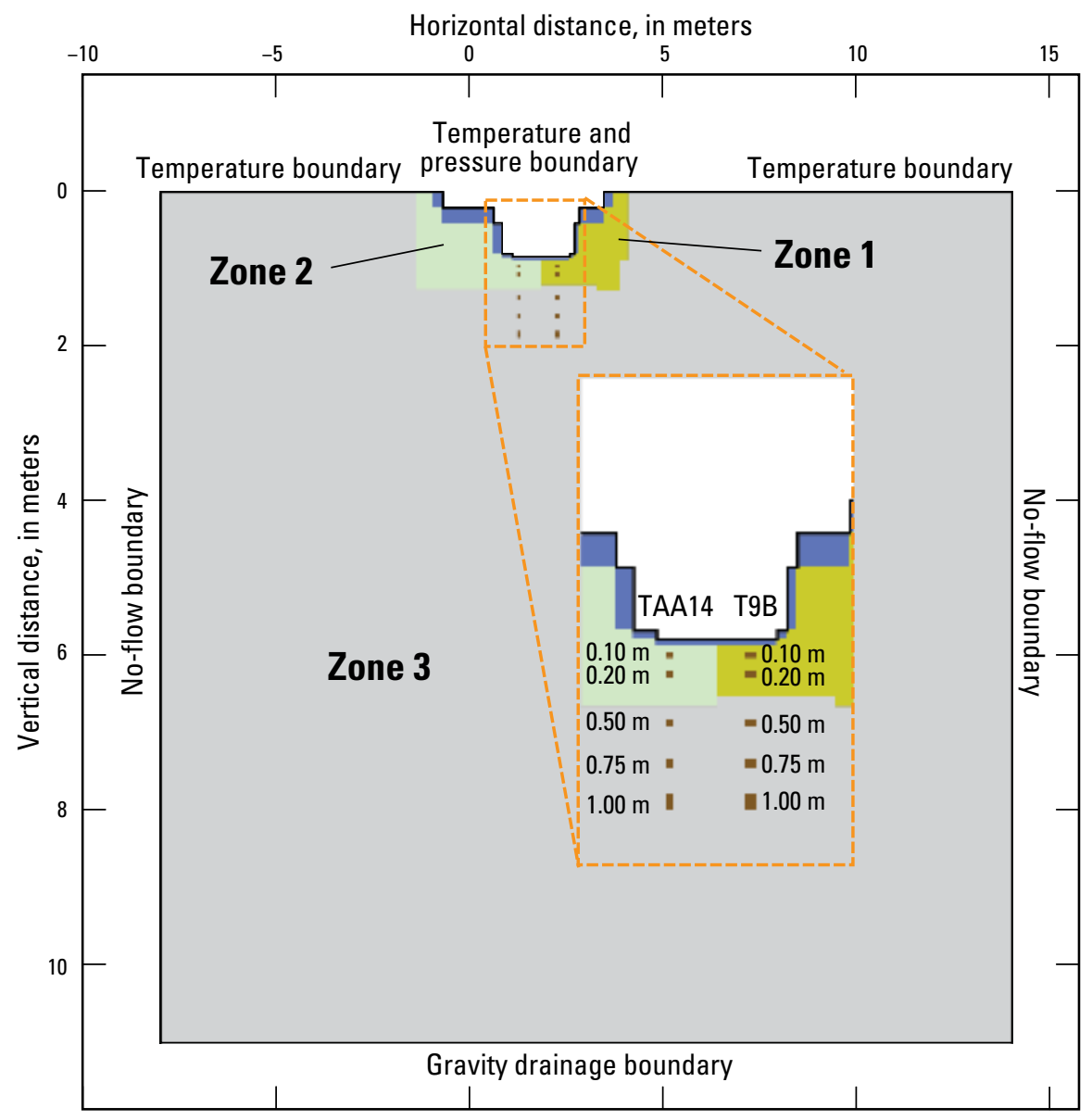

Figure 2B-10. Schematic cross section of two-dimensional VS2DH model of water and heat transport through canal-bed sediments at MICKEY DITCH 1.1 site with soil textural zones (Zones 1-3), locations of temperature observations below ground surface within the canal (TAA14 and T9B), and specified vertical and horizontal boundary conditions. 
$\boldsymbol{A}$

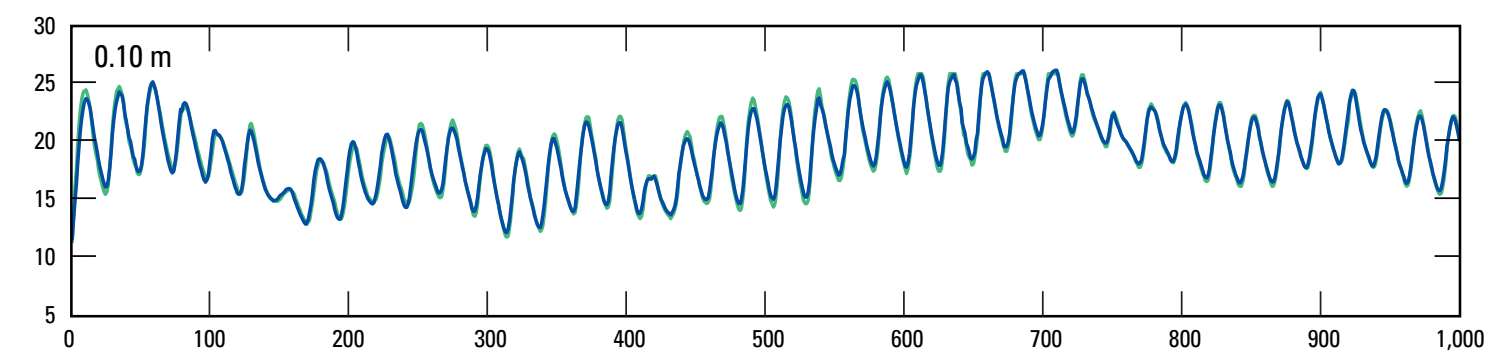

$\boldsymbol{B}$

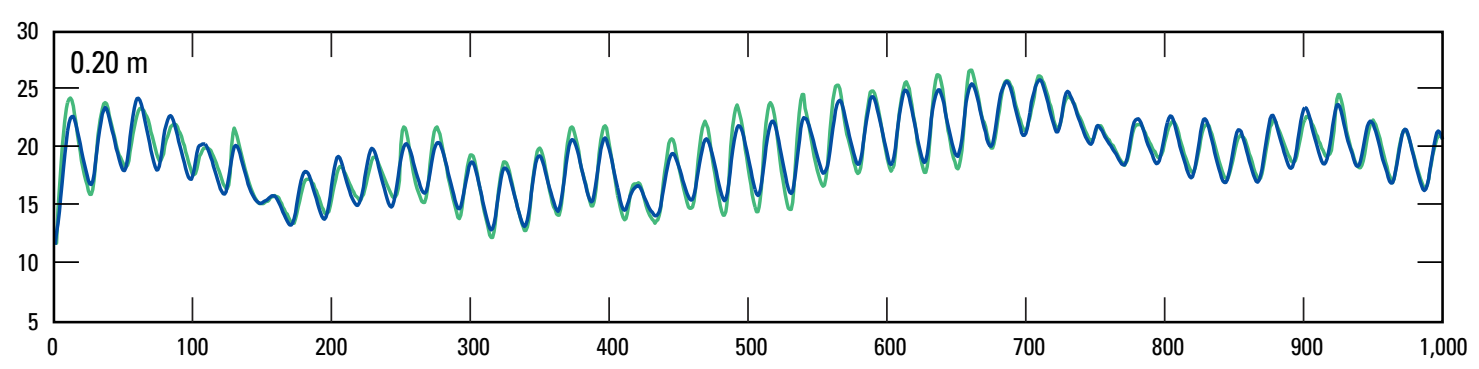

C

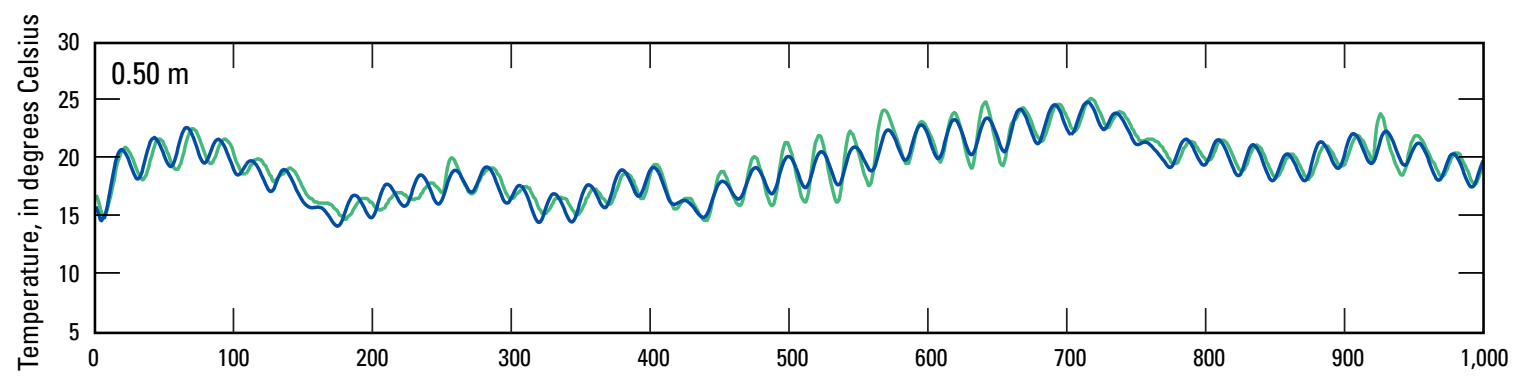

D

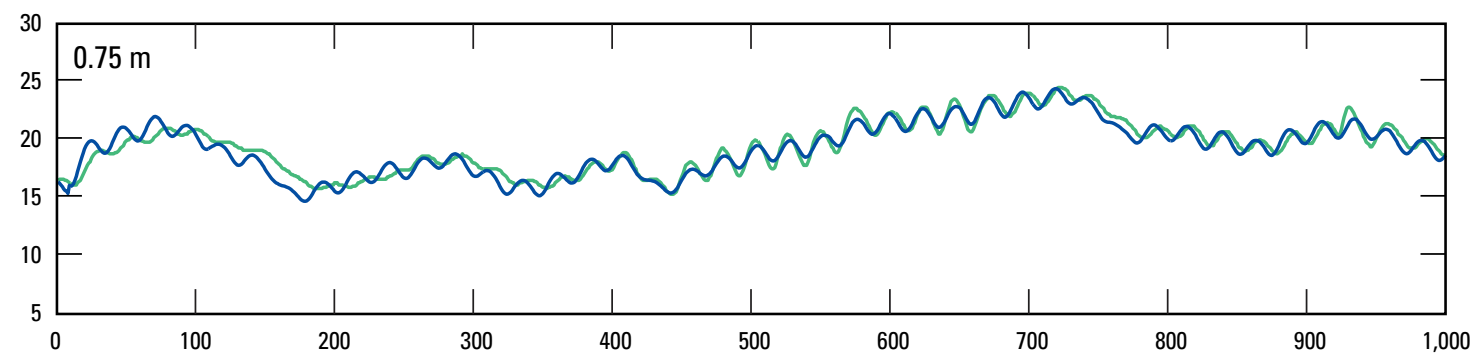

E

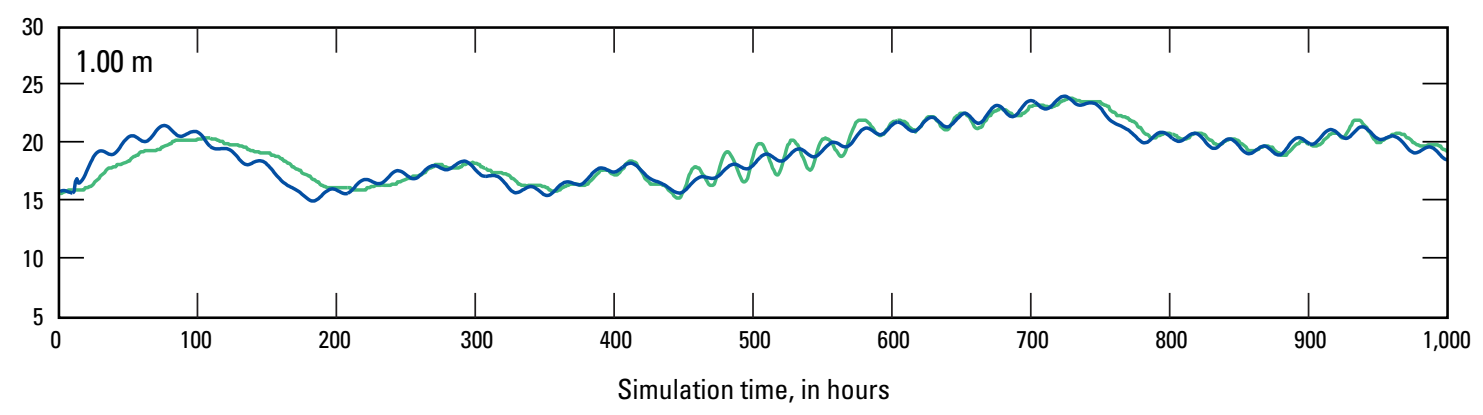

\section{EXPLANATION}

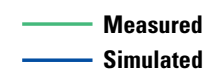

Figure 2B-11. Measured and simulated thermographs for canal sediments for TAA14 at depths of $A, 0.10 \mathrm{~m}, \mathrm{~B}, 0.20 \mathrm{~m}, \mathrm{C}, 0.50 \mathrm{~m}$, $\mathrm{D}, 0.75 \mathrm{~m}$, and $\mathrm{E}, 1.0 \mathrm{~m}$ for the 2013 calibration period. 
A

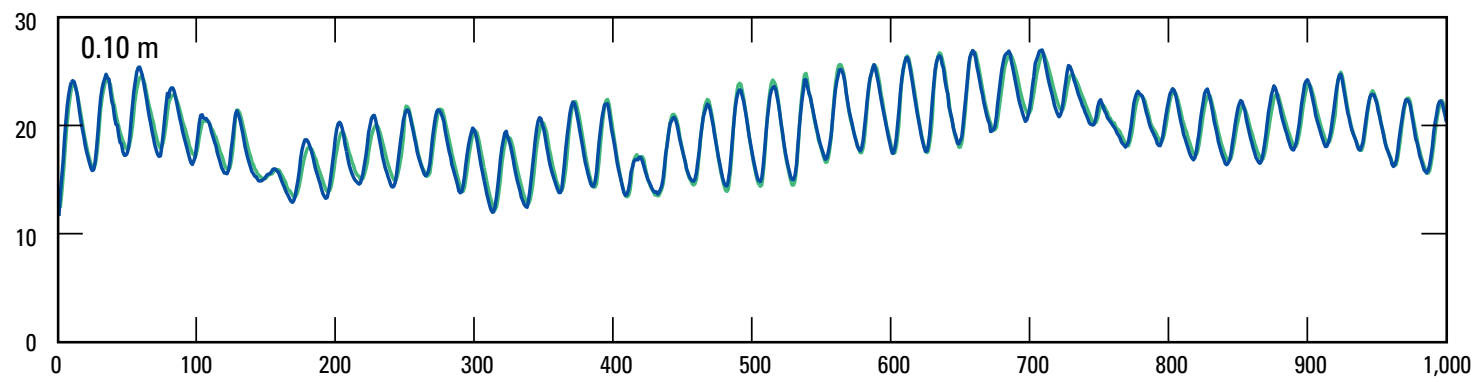

B

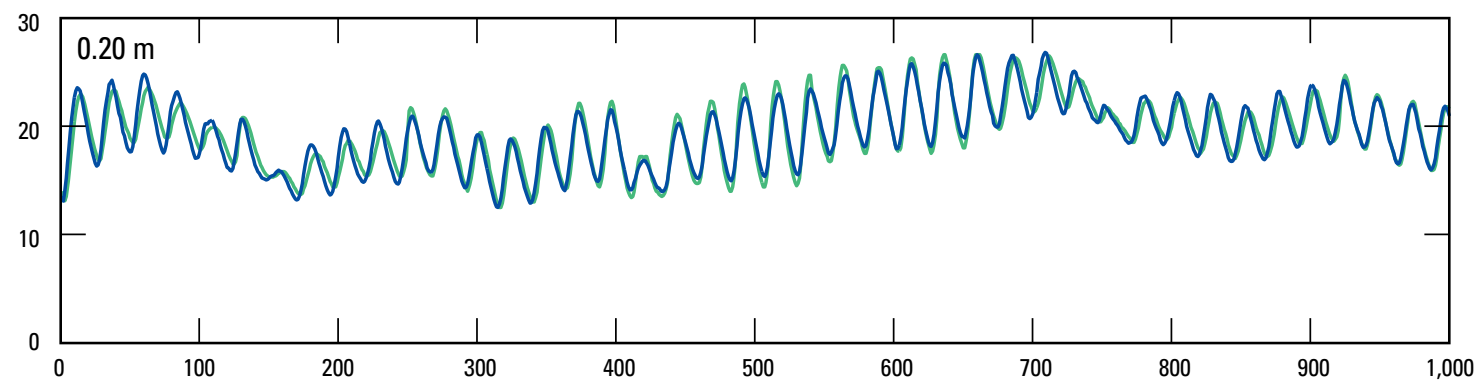

C

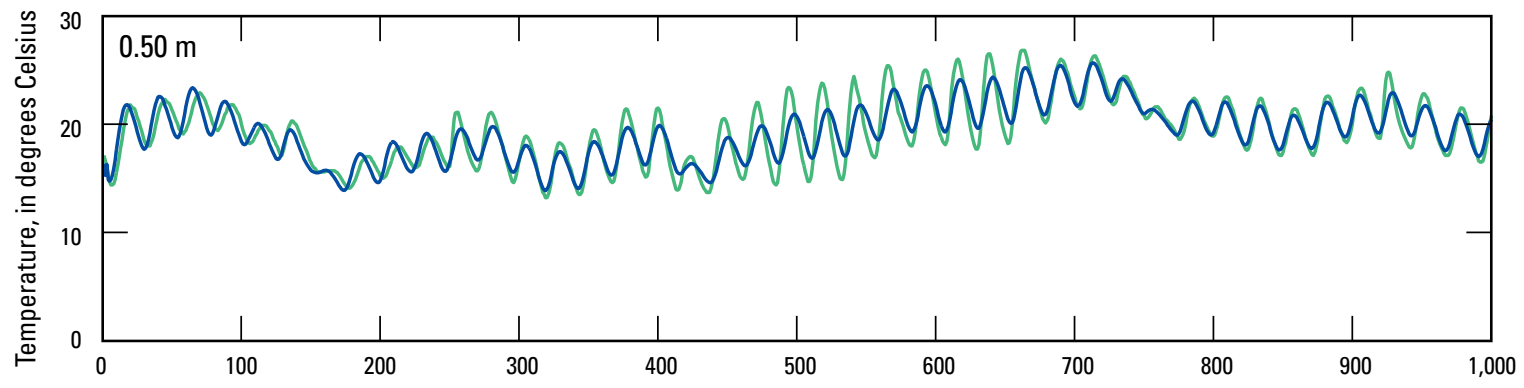

D

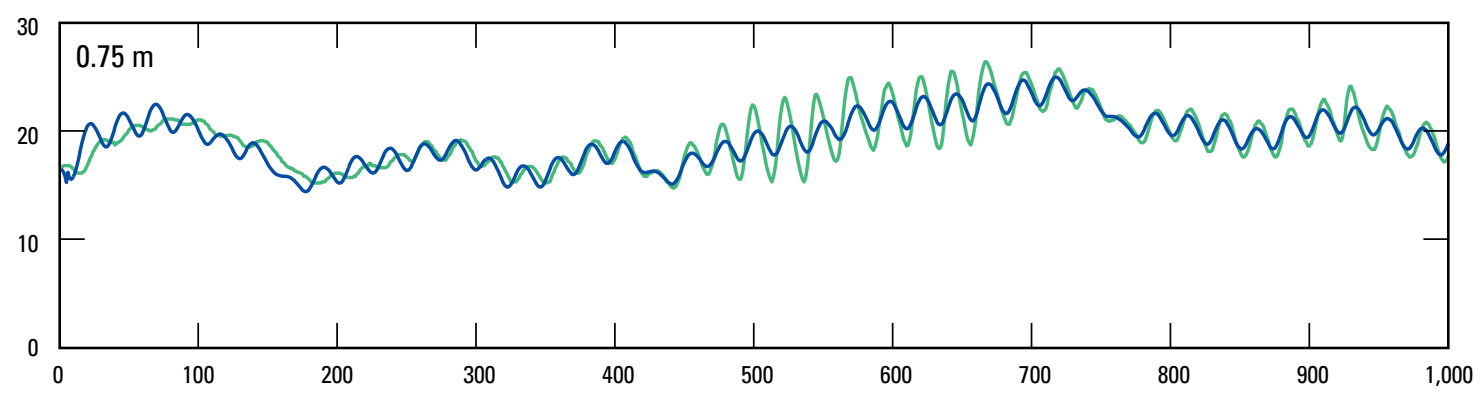

E

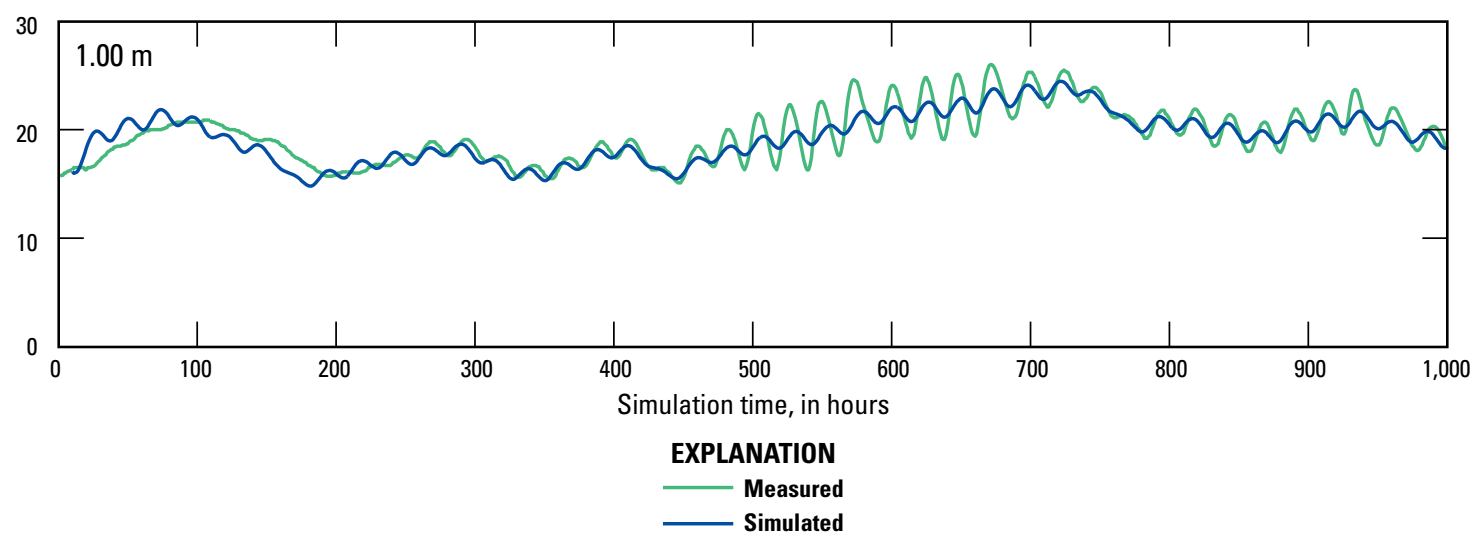

Figure 2B-12. Measured and simulated thermographs for canal sediments for T9B at depths of $A, 0.10 \mathrm{~m}, \mathrm{~B}, 0.20 \mathrm{~m}, \mathrm{C}, 0.50 \mathrm{~m}, \mathrm{D}, 0.75 \mathrm{~m}$, and $\mathrm{E}, 1.0 \mathrm{~m}$ for the 2013 calibration period. 

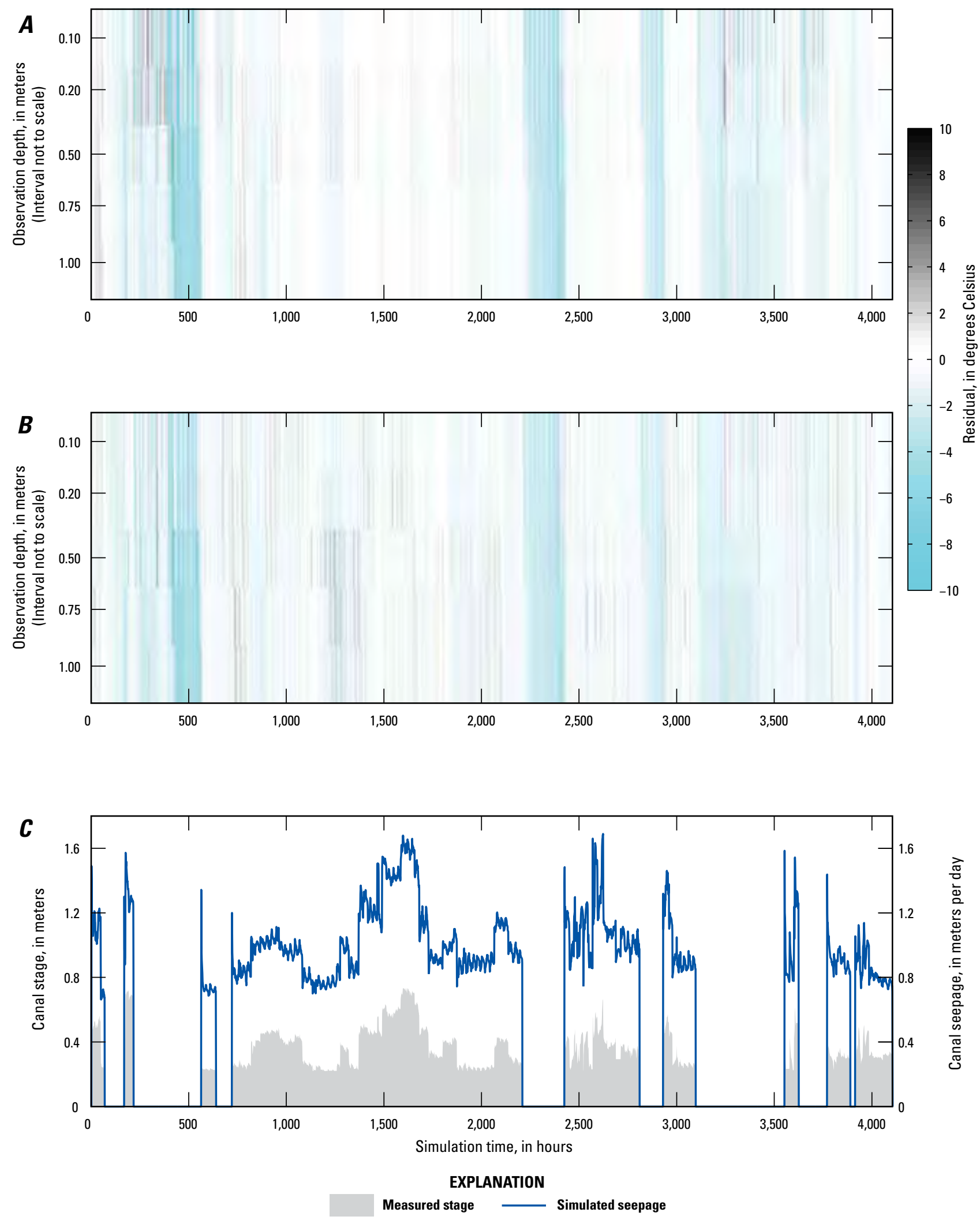

Figure 2B-13. Temperature residual for each depth below the canal at location A, TAA14 and B, T9B, and C, measured stage and simulated seepage for the 2013 prediction period. 


\section{Appendix 2C Temperature and Model Results for Campbell Ditch 1, Mason Valley, Nevada}

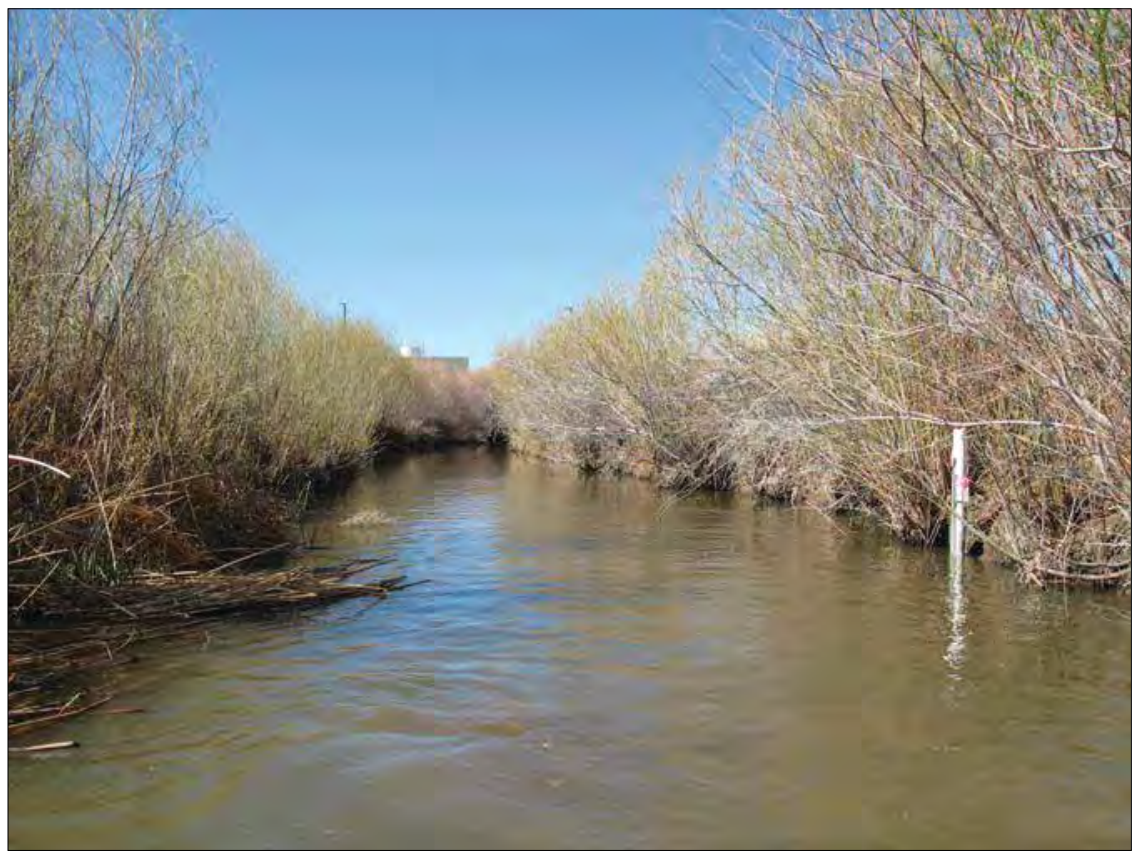

Figure 2C-1. Photograph of CAMPBELL DITCH 1 site, Yerrington, Nevada. Photograph taken by Steven Clarke, U.S. Geological Survey, looking downstream on 4/18/2013.

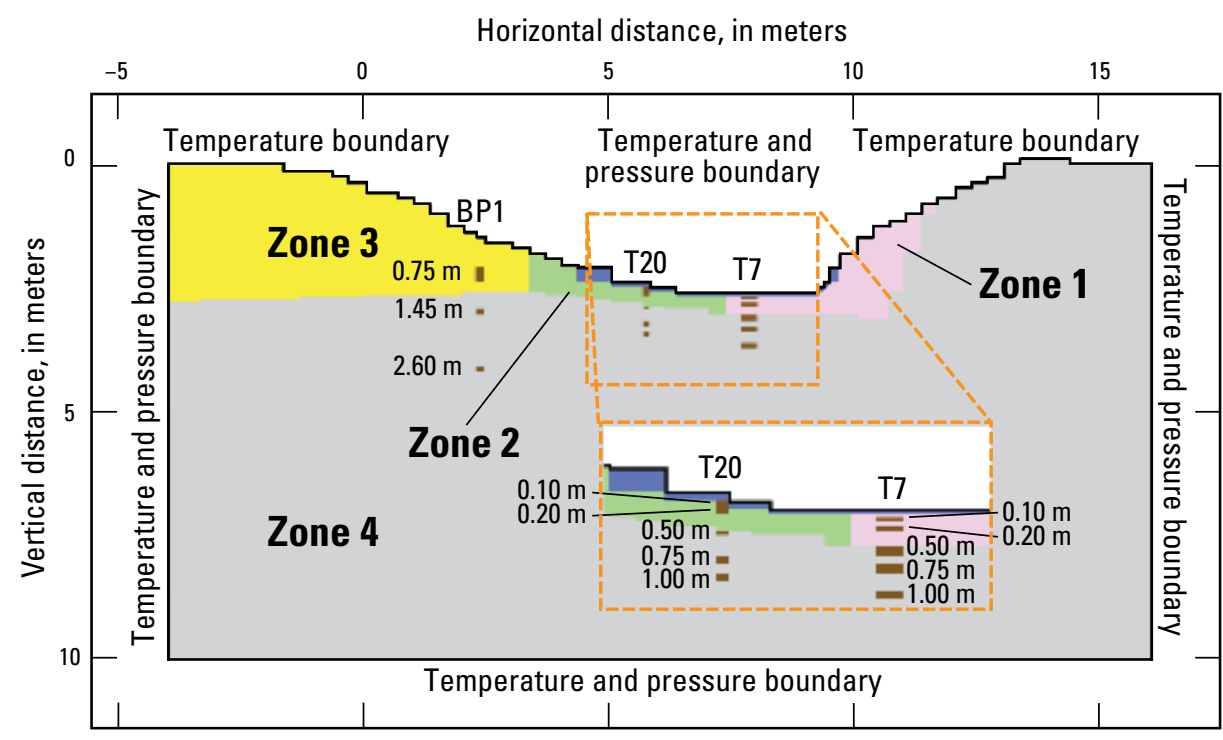

Figure 2C-2. Schematic cross section of two-dimensional VS2DH model of water and heat transport through canal-bed sediments at CAMPBELL DITCH 1 site with soil textural zones (Zones 1-4), locations of temperature observations below ground surface within the canal (T7 and T20) and along the banks (BP1), and specified vertical and horizontal boundary conditions. 

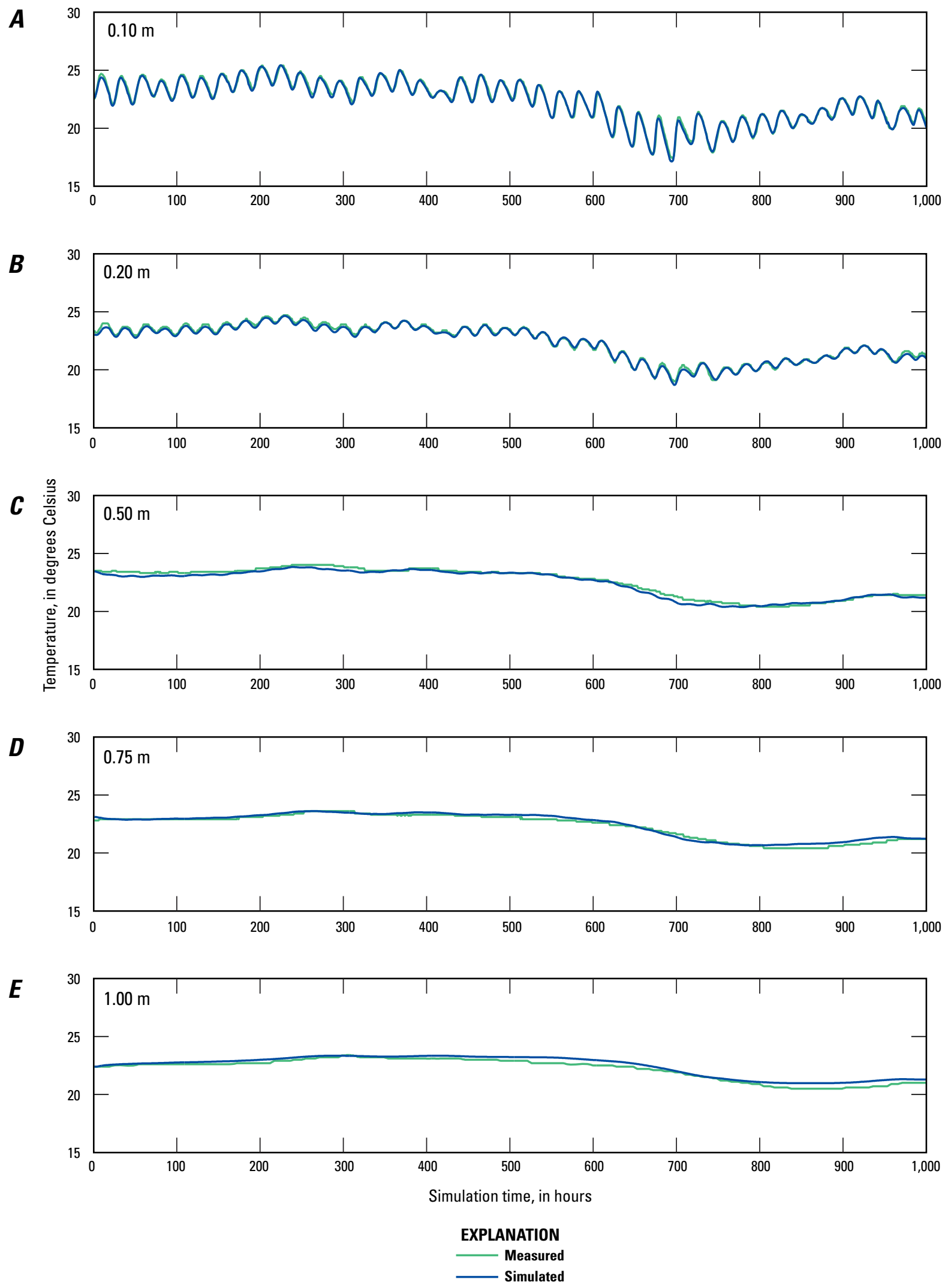

Figure 2C-3. Measured and simulated thermographs for canal sediments for T7 at depths of $A, 0.10 \mathrm{~m}, \mathrm{~B}, 0.20 \mathrm{~m}, \mathrm{C}, 0.50 \mathrm{~m}, \mathrm{D}, 0.75 \mathrm{~m}$, and $\mathrm{E}, 1.0 \mathrm{~m}$ for the 2012 calibration period. 
$\boldsymbol{A}$

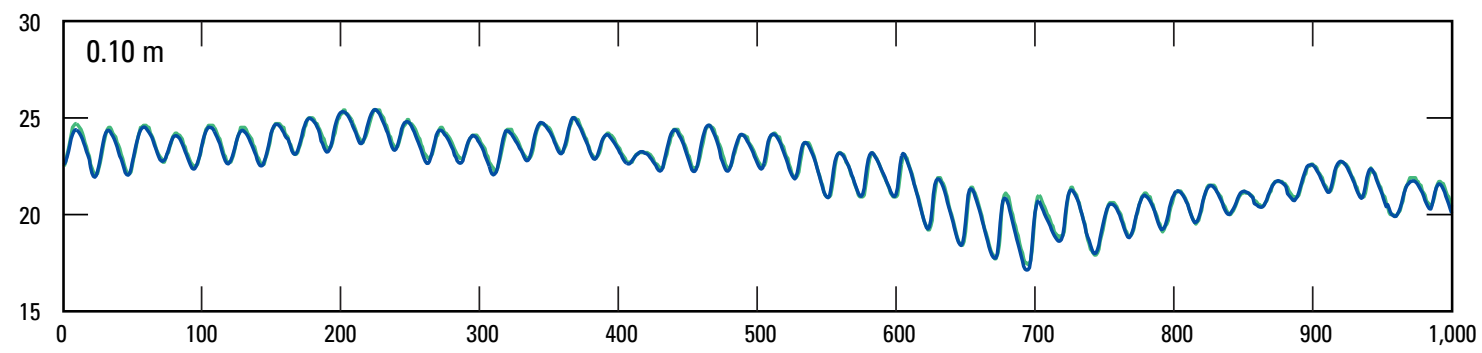

B

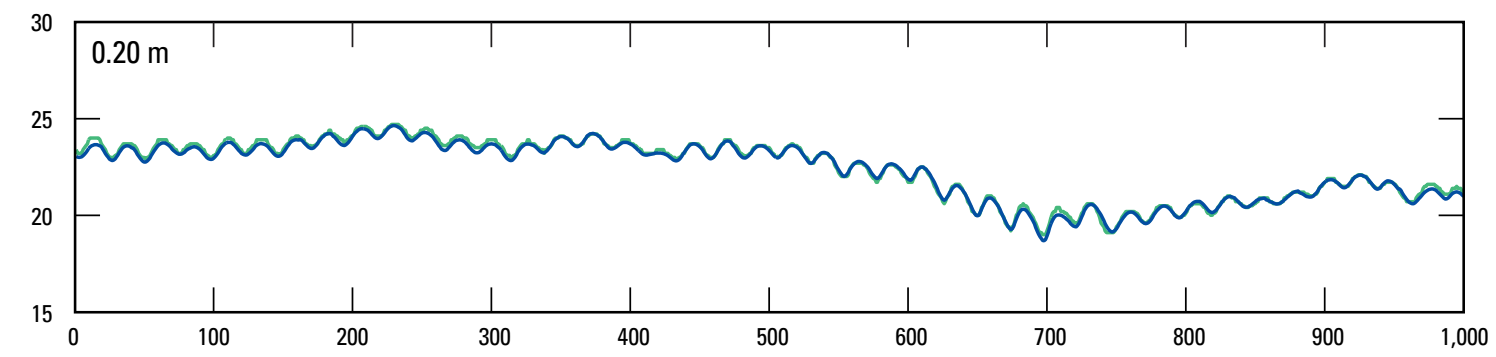

c

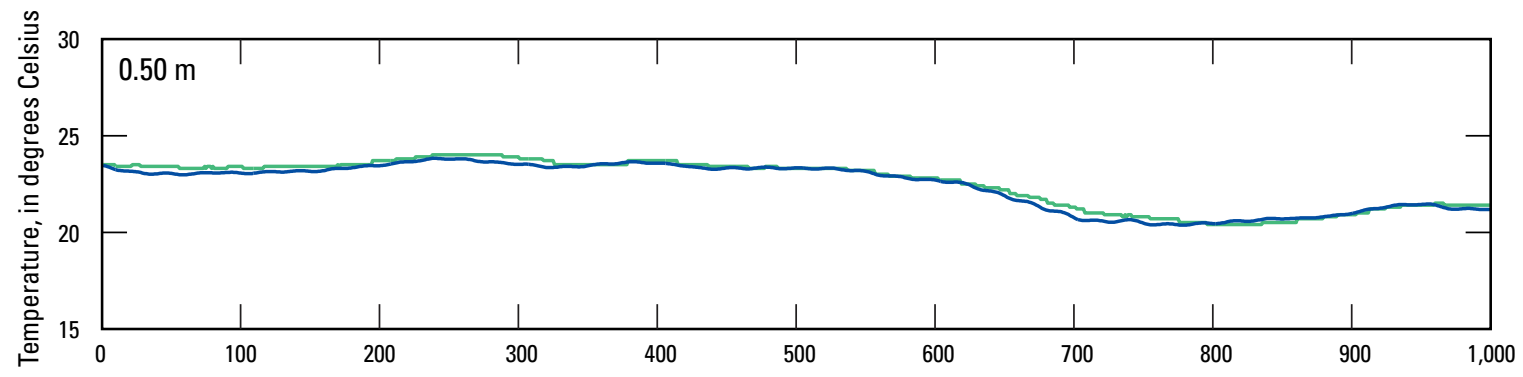

D
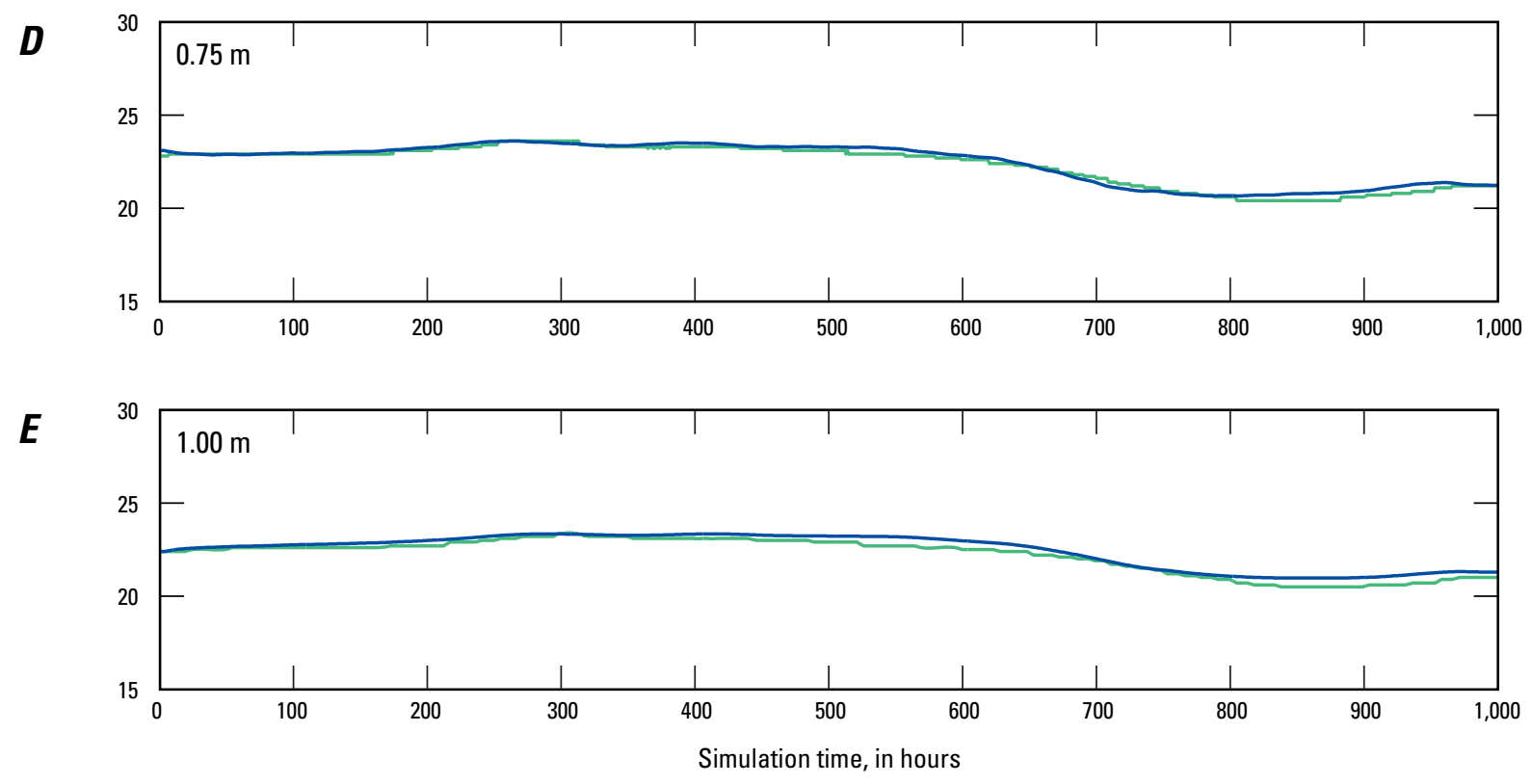

EXPLANATION

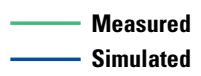

Figure 2C-4. Measured and simulated thermographs for canal sediments for T20 at depths of $A, 0.20 \mathrm{~m}, \mathrm{~B}, 0.50 \mathrm{~m}, \mathrm{C}, 0.75 \mathrm{~m}$, and D, $1.0 \mathrm{~m}$ for the 2012 calibration period. 

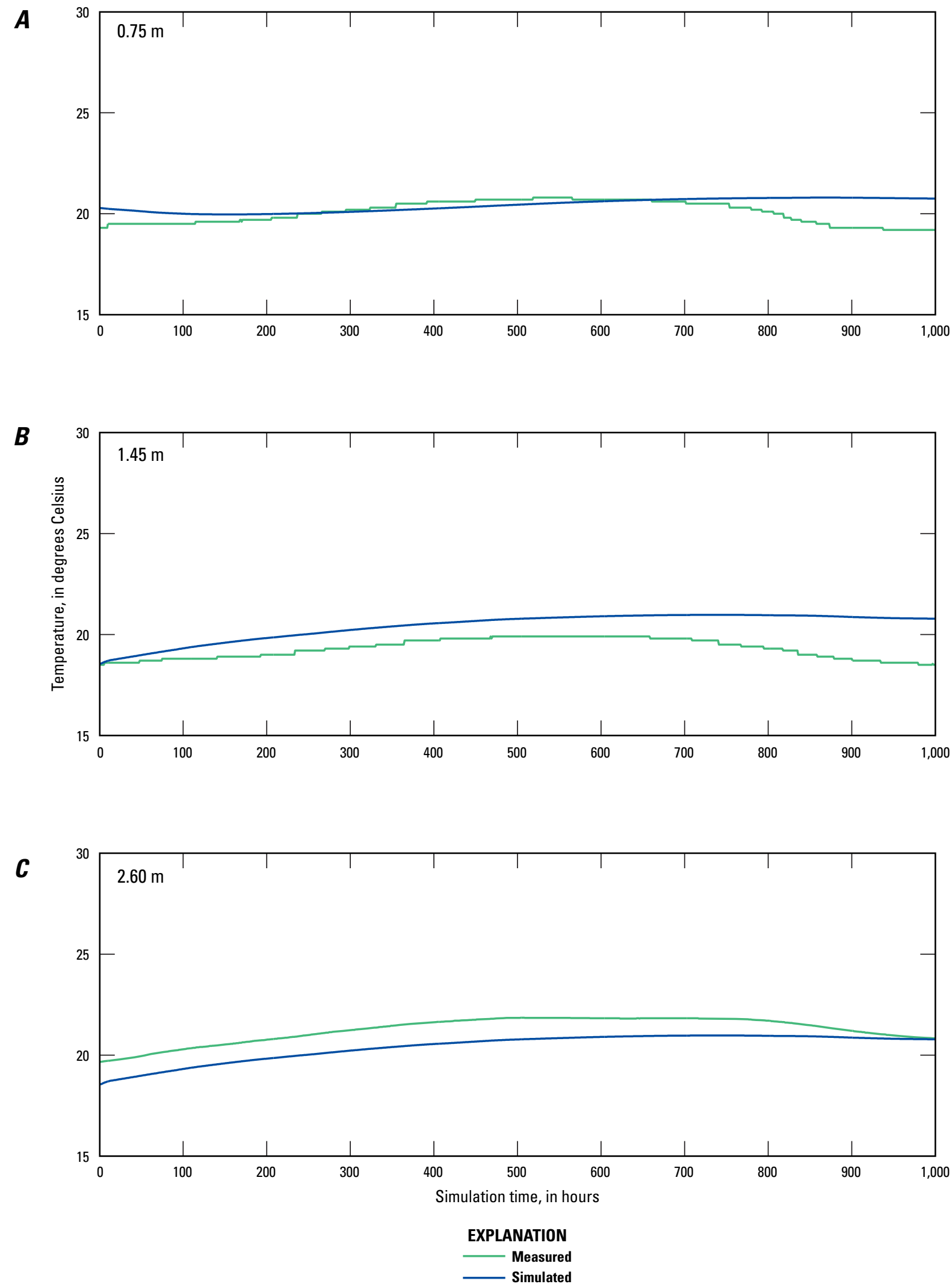

Figure 2C-5. Measured and simulated thermographs for Bank Piezometer 1 (BP1) observations at depths of $A, 0.75 \mathrm{~m}, B, 1.45 \mathrm{~m}$, and C, $2.60 \mathrm{~m}$ for the 2012 calibration period. 


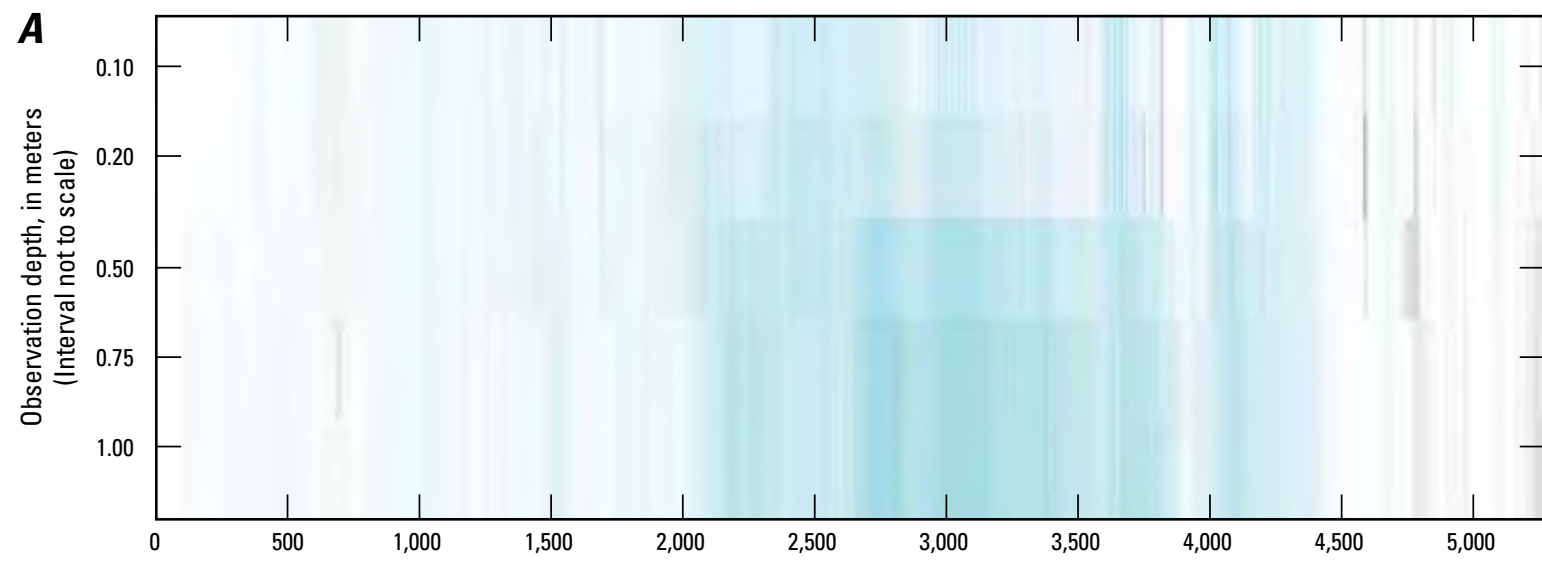

B

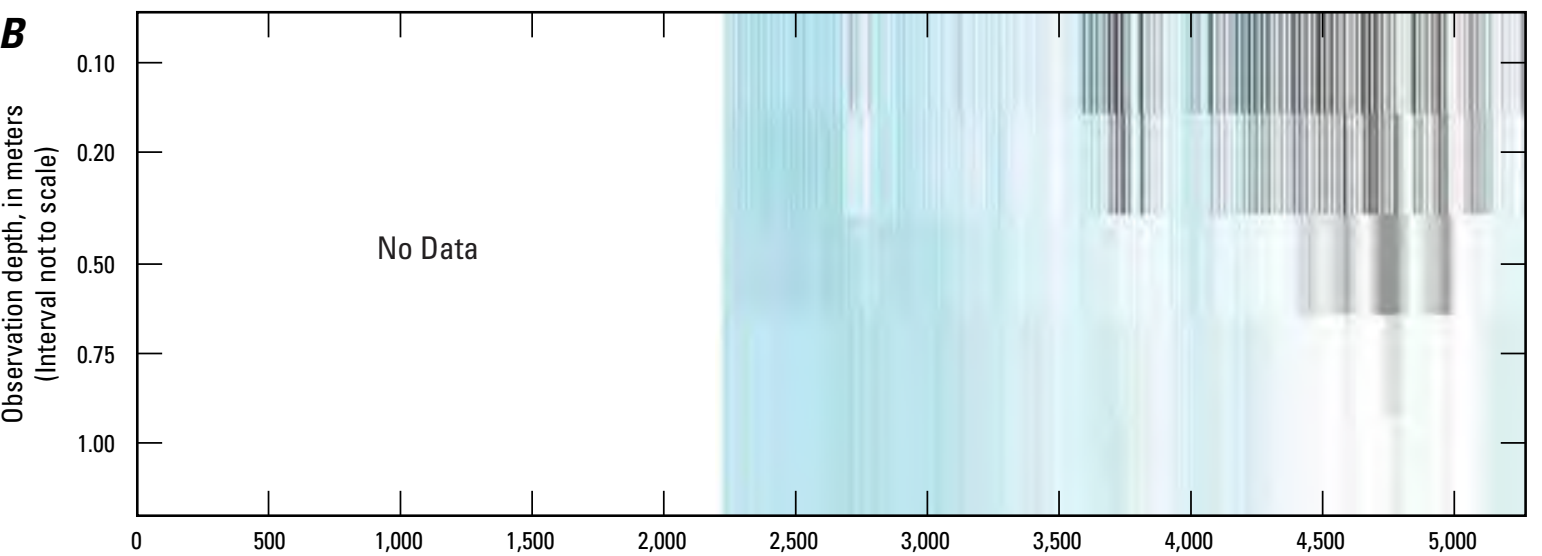

C

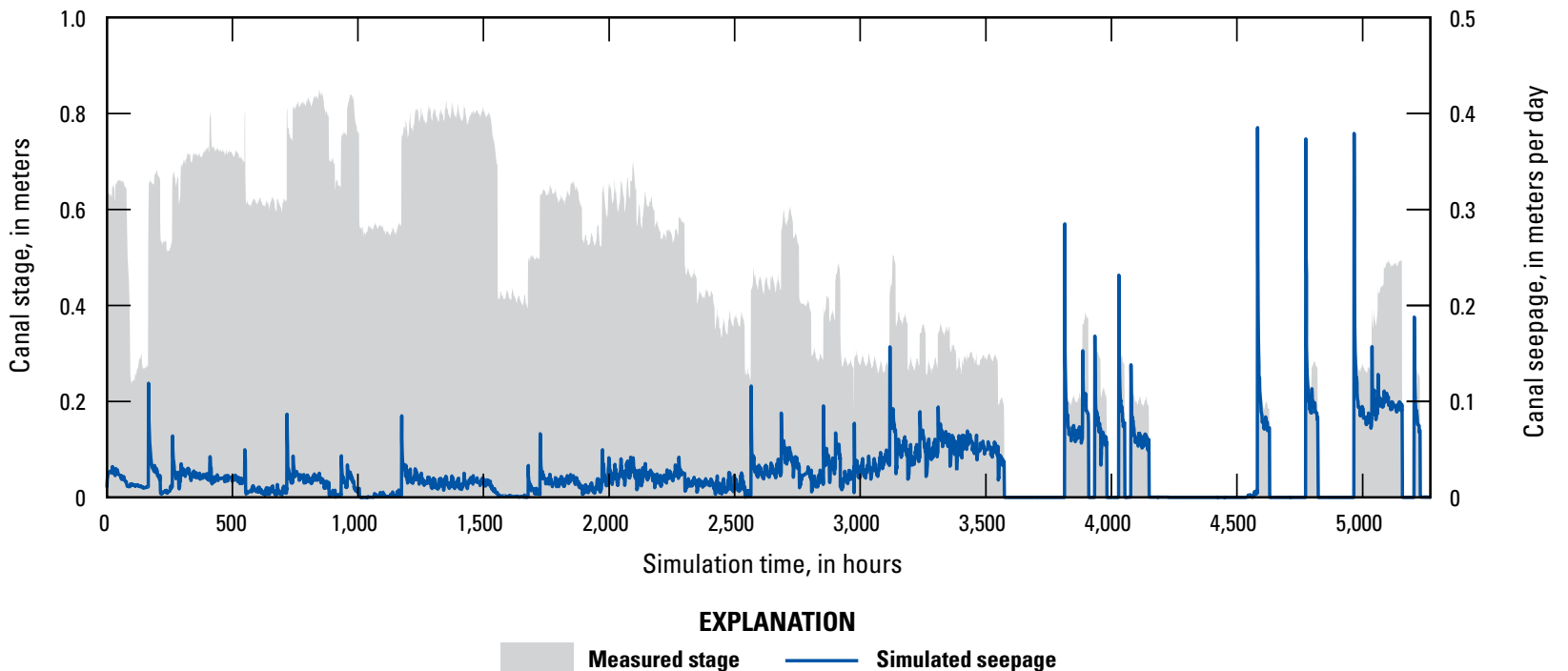

Figure 2C-6. Temperature residual for each depth below the canal at location A, T7 and B, T20, and C, measured stage and simulated seepage for the 2012 prediction period. 

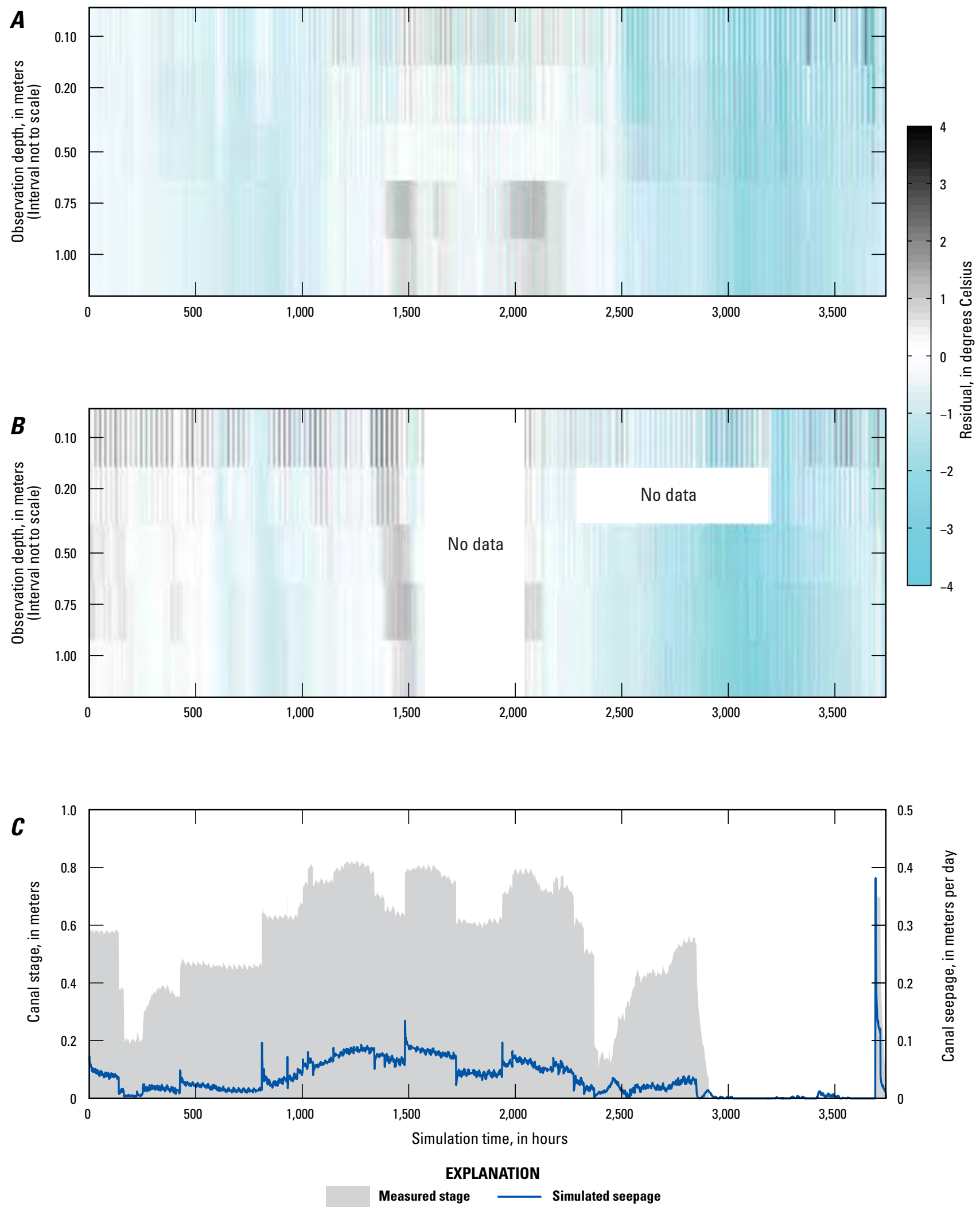

Figure 2C-7. Temperature residual for each depth below the canal at location $\mathrm{A}, \mathrm{T7}$ and $\mathrm{B}, \mathrm{T} 20$, and $\mathrm{C}$, measured stage and simulated seepage for the 2013 prediction period. 


\section{Appendix 2C Temperature and Model Results for Campbell Ditch 1.1, Mason Valley, Nevada}

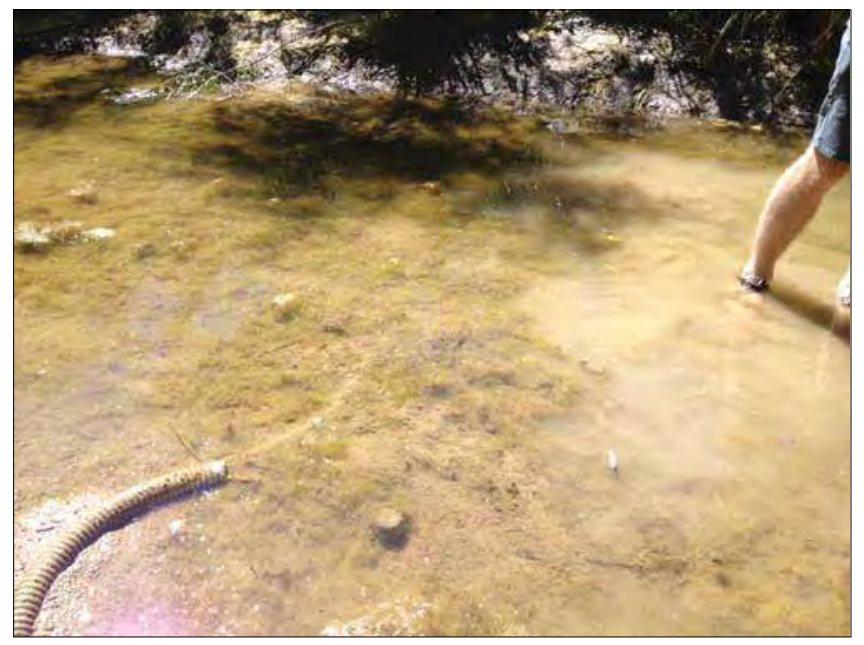

Figure 2C-8. Photograph of CAMPBELL DITCH 1.1 site, Yerrington, Nevada. Photograph taken by Steven Clarke, U.S. Geological Survey. View of right bank on $7 / 12 / 2013$.

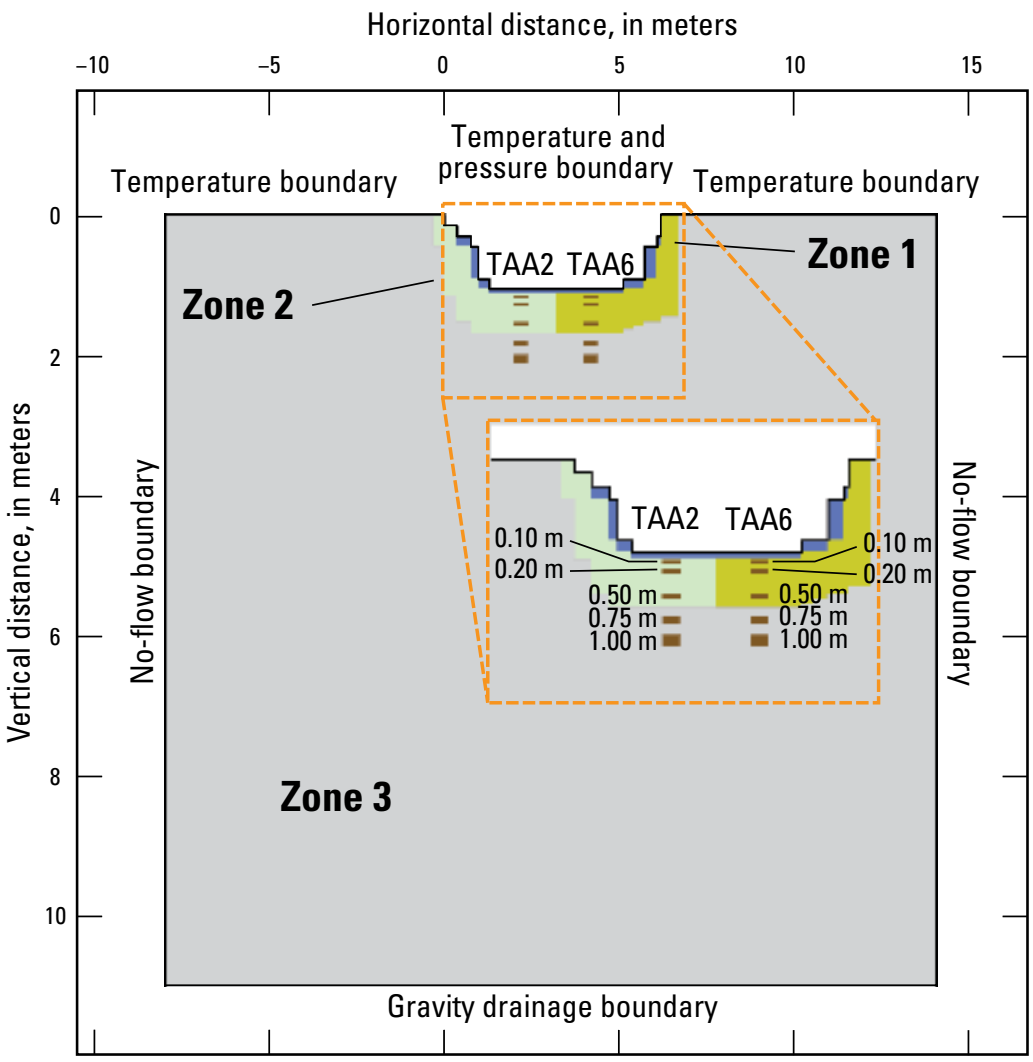

Figure 2C-9. Schematic cross section of two-dimensional VS2DH model of water and heat transport through canal-bed sediments at CAMPBELL DITCH 1.1 site with soil textural zones (Zones 1-3), locations of temperature observations below ground surface within the canal (TAA2 and TAA6), and specified vertical and horizontal boundary conditions. 
A

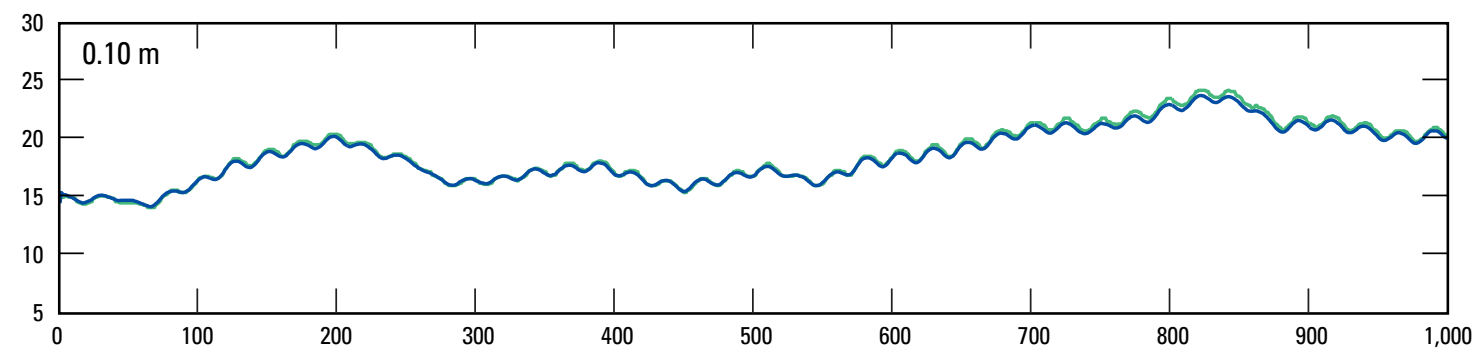

B

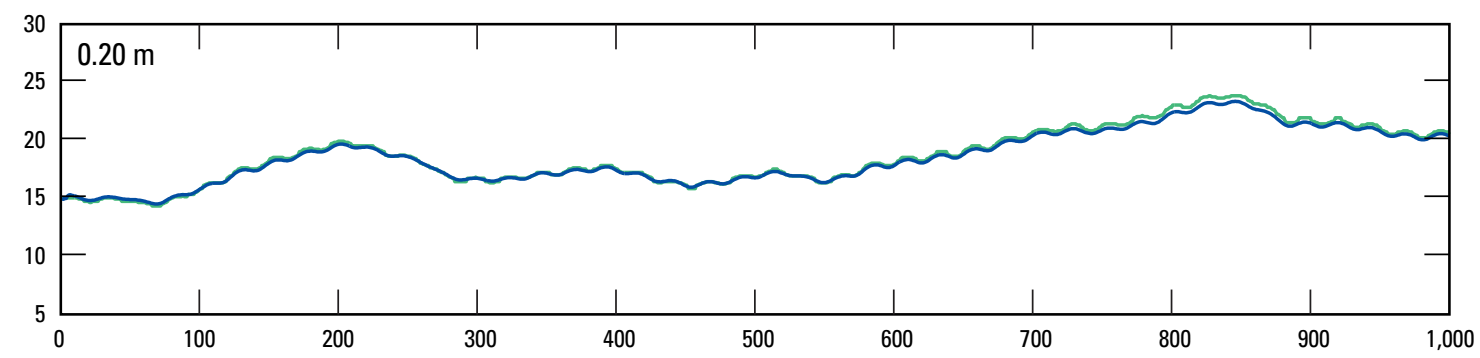

C

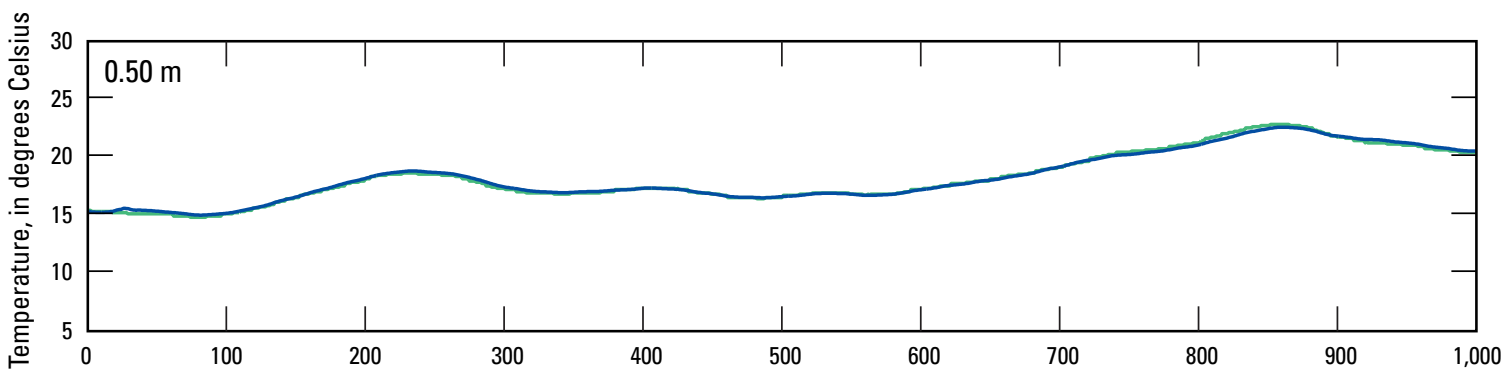

D

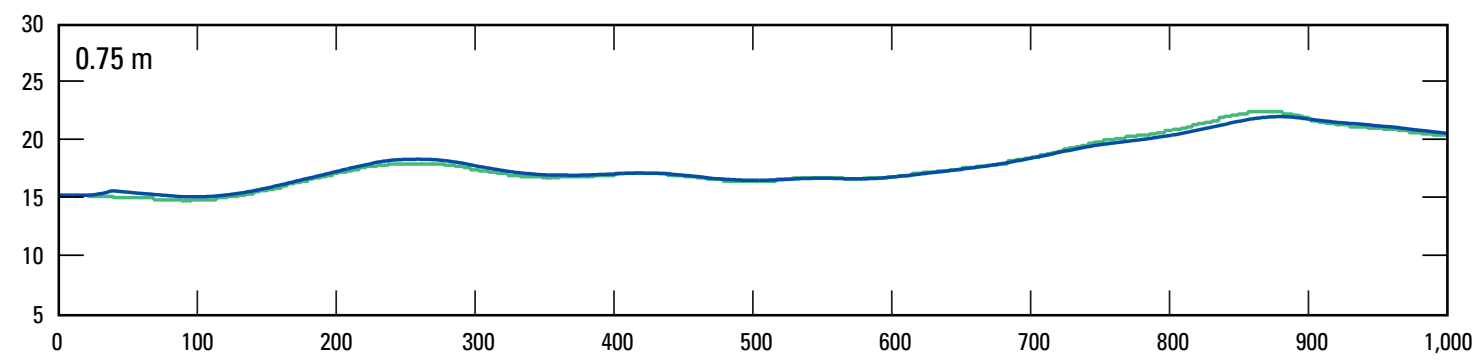

E

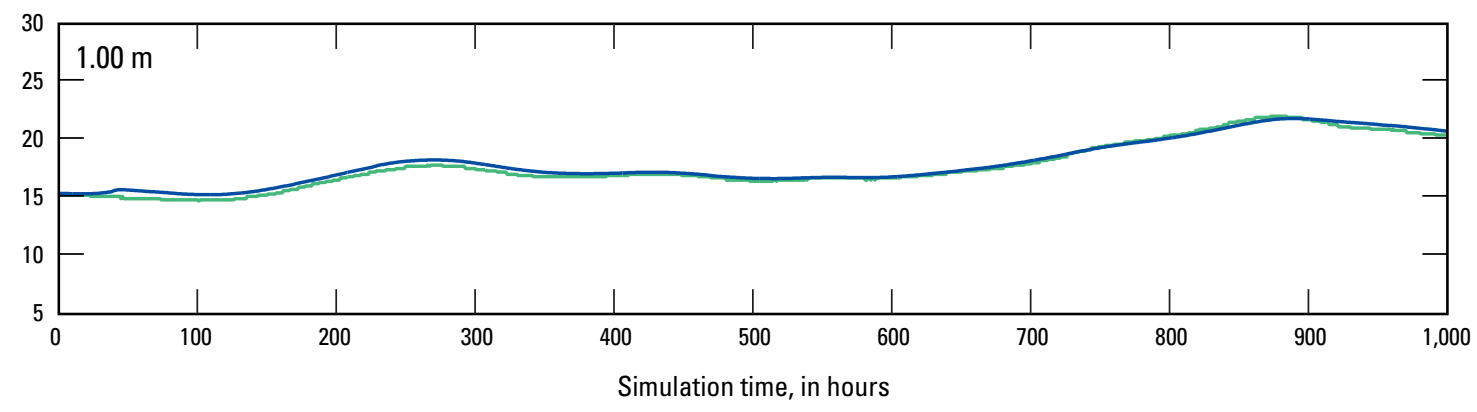

EXPLANATION

Measured

Simulated

Figure 2C-10. Measured and simulated thermographs for canal sediments for TAA2 at depths of $A, 0.10 \mathrm{~m}, \mathrm{~B}, 0.20 \mathrm{~m}, \mathrm{C}, 0.50 \mathrm{~m}, \mathrm{D}, 0.75 \mathrm{~m}$, and $\mathrm{E}, 1.0 \mathrm{~m}$ for the 2013 calibration period. 

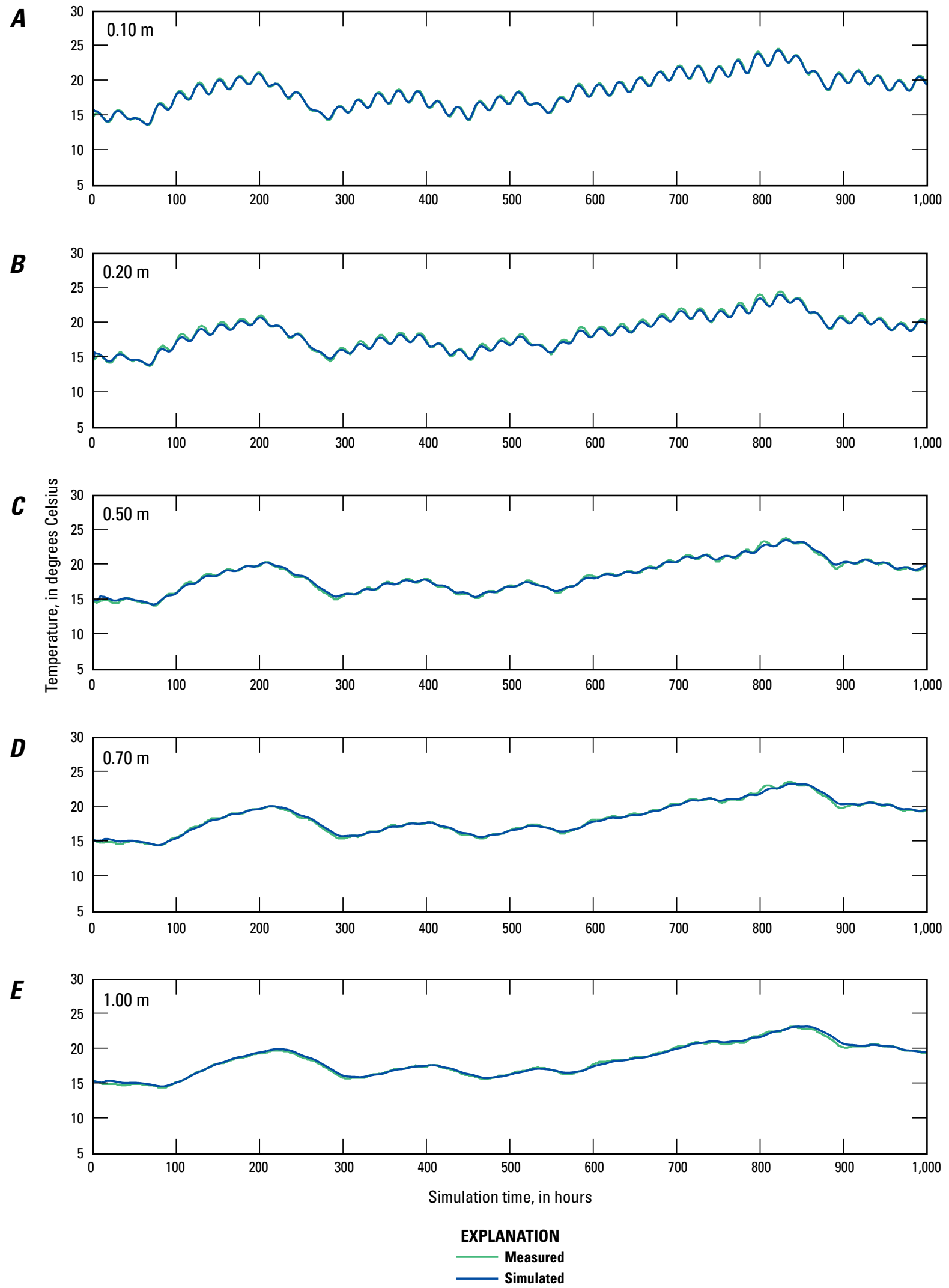

Figure 2C-11. Measured and simulated thermographs for canal sediments for TAA6 at depths of $A, 0.10 \mathrm{~m}, \mathrm{~B}, 0.20 \mathrm{~m}, \mathrm{C}, 0.50 \mathrm{~m}, \mathrm{D}, 0.75 \mathrm{~m}$, and $\mathrm{E}, 1.0 \mathrm{~m}$ for the 2013 calibration period. 

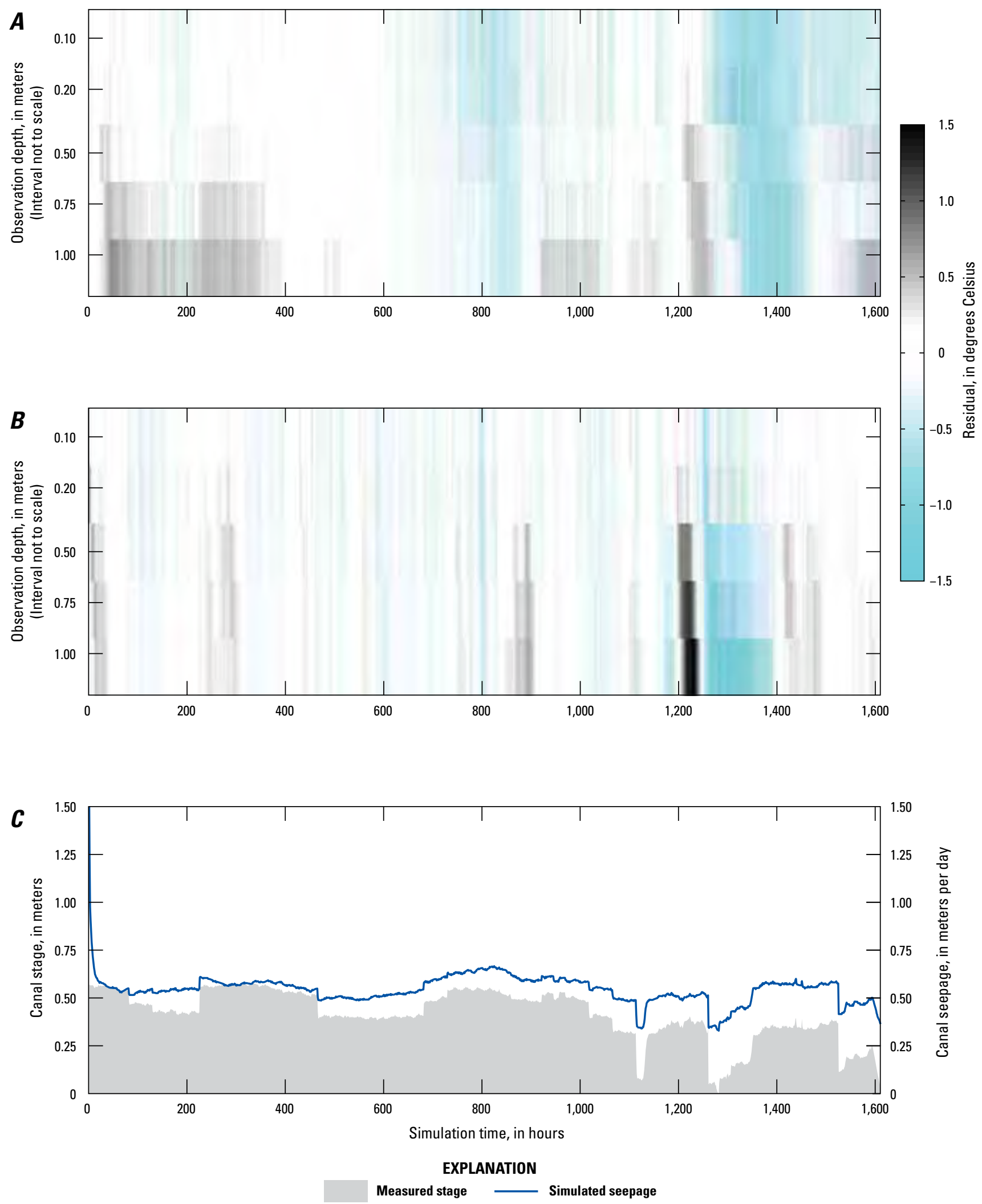

Figure 2C-12. Temperature residual for each depth below the canal at location A, TAA2 and B, TAA6, and C, measured stage and simulated seepage for the 2013 prediction period. 


\section{Appendix 2C Temperature and Model Results for Campbell Ditch 2, Mason Valley, Nevada}

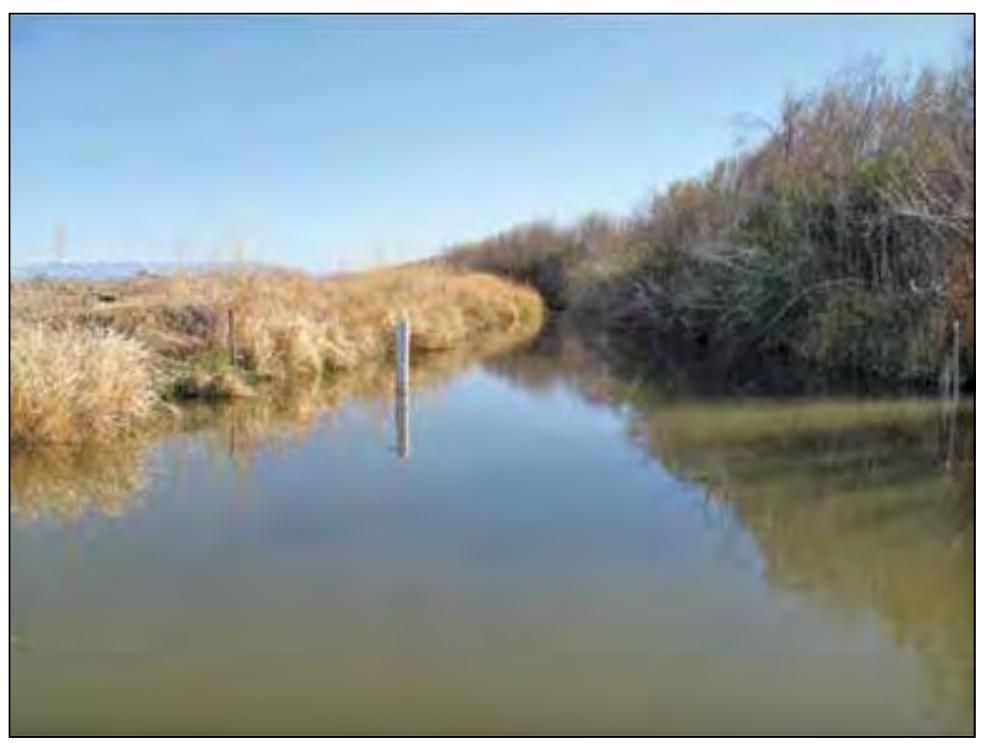

Figure 2C-13. Photograph of CAMPBELL DITCH 2 site, Yerrington, Nevada. Photograph taken by Steven Clarke, U.S. Geological Survey, looking upstream on 4/18/2013.

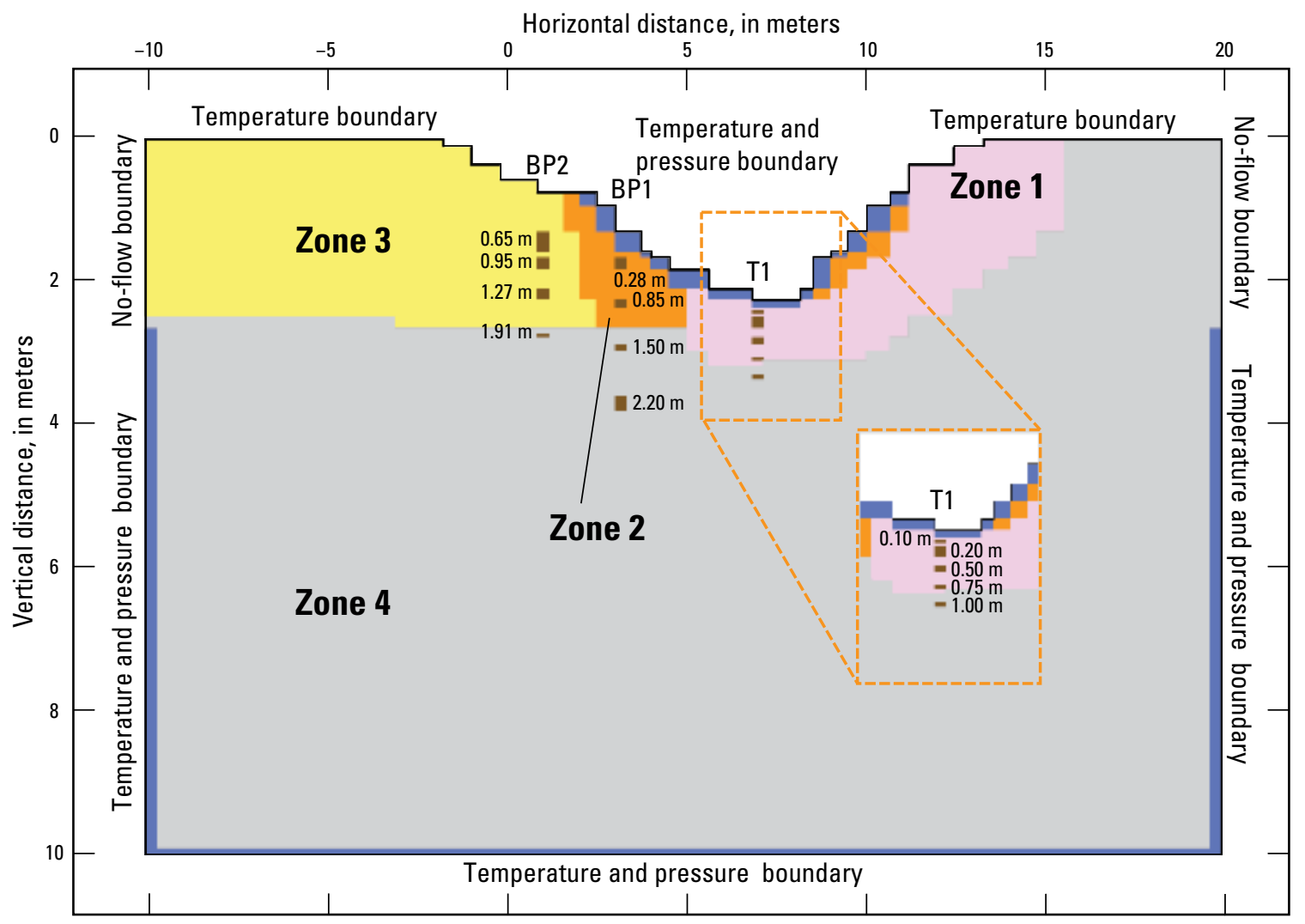

Figure 2C-14. Schematic cross section of two-dimensional VS2DH model of water and heat transport through canal-bed sediments at CAMPBELL DITCH 2 site with soil textural zones (Zones 1-4), locations of temperature observations below ground surface within the canal (T1) and along the banks (BP1 and BP2), and specified vertical and horizontal boundary conditions. 
A

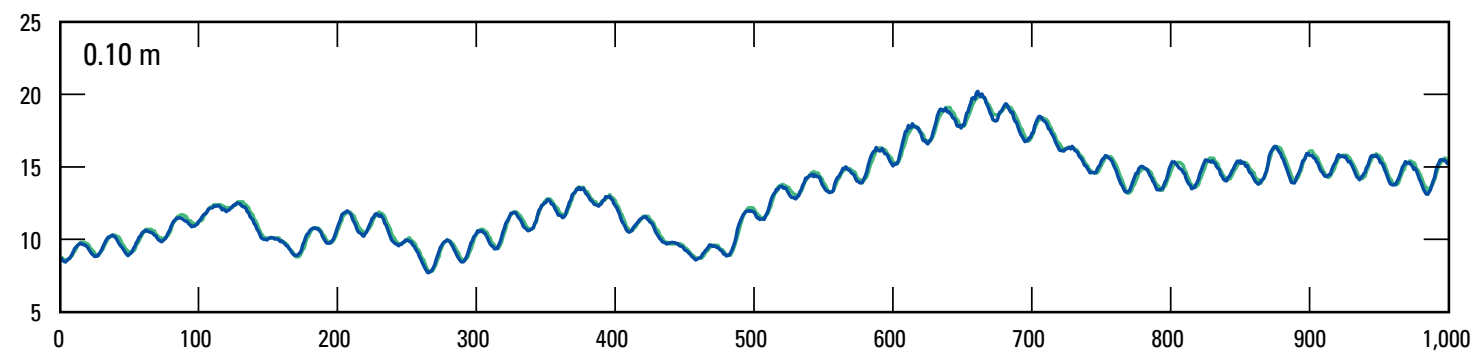

B

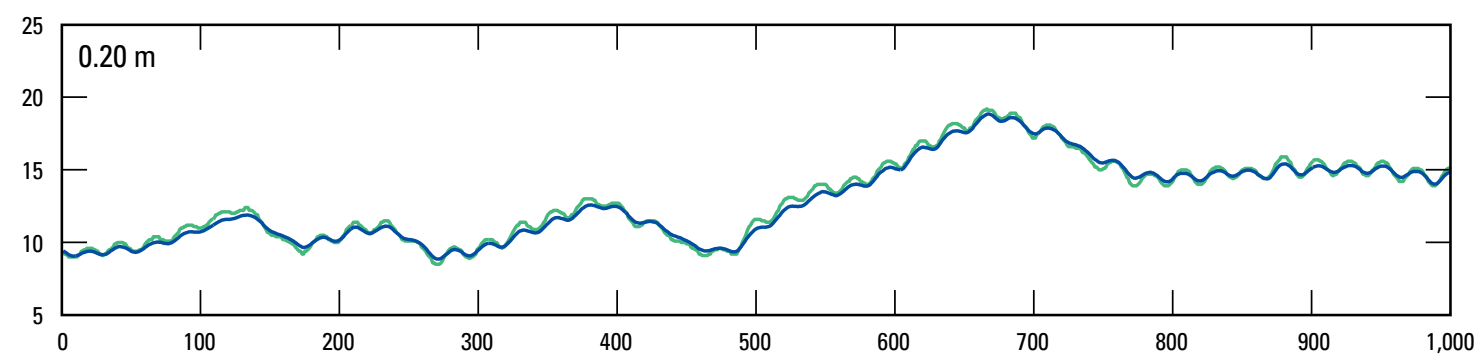

$\boldsymbol{C}$

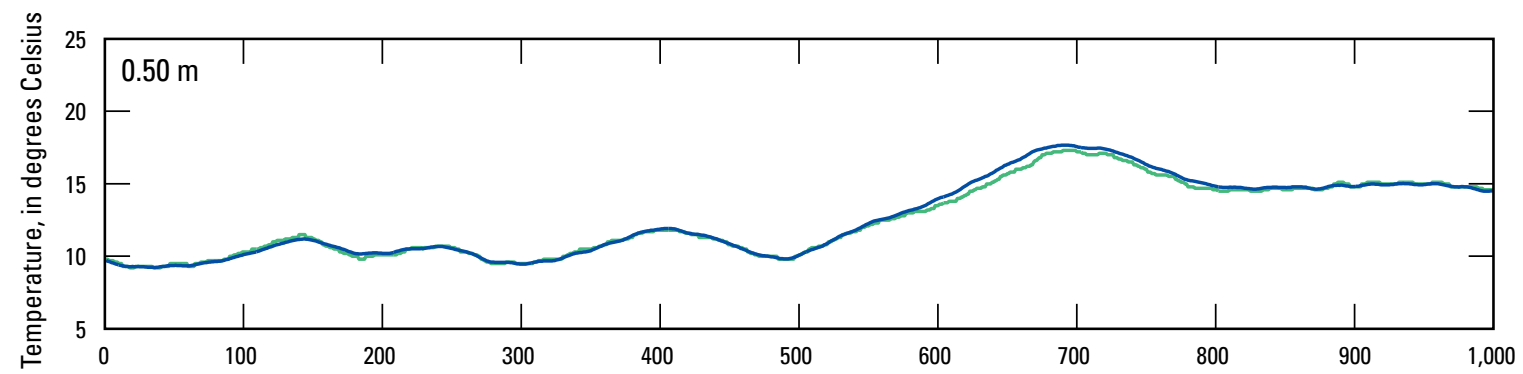

$\boldsymbol{D}$

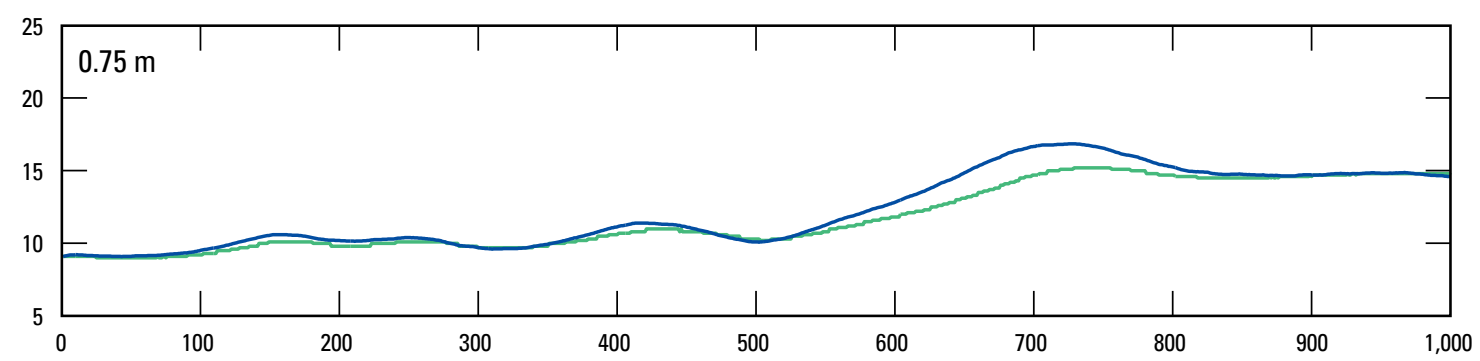

E

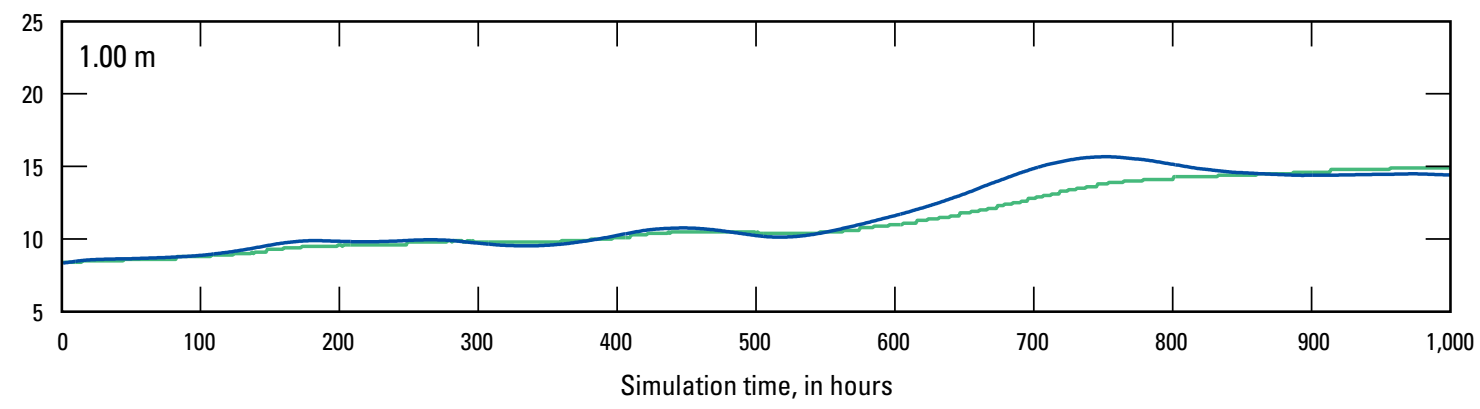

EXPLANATION

Measured

Simulated

Figure 2C-15. Measured and simulated thermographs for canal sediments for T1 at depths of $A, 0.10 \mathrm{~m}, \mathrm{~B}, 0.20 \mathrm{~m}, \mathrm{C}, 0.50 \mathrm{~m}, \mathrm{D}, 0.75 \mathrm{~m}$, and $E, 1.0 \mathrm{~m}$ for the 2012 calibration period. 

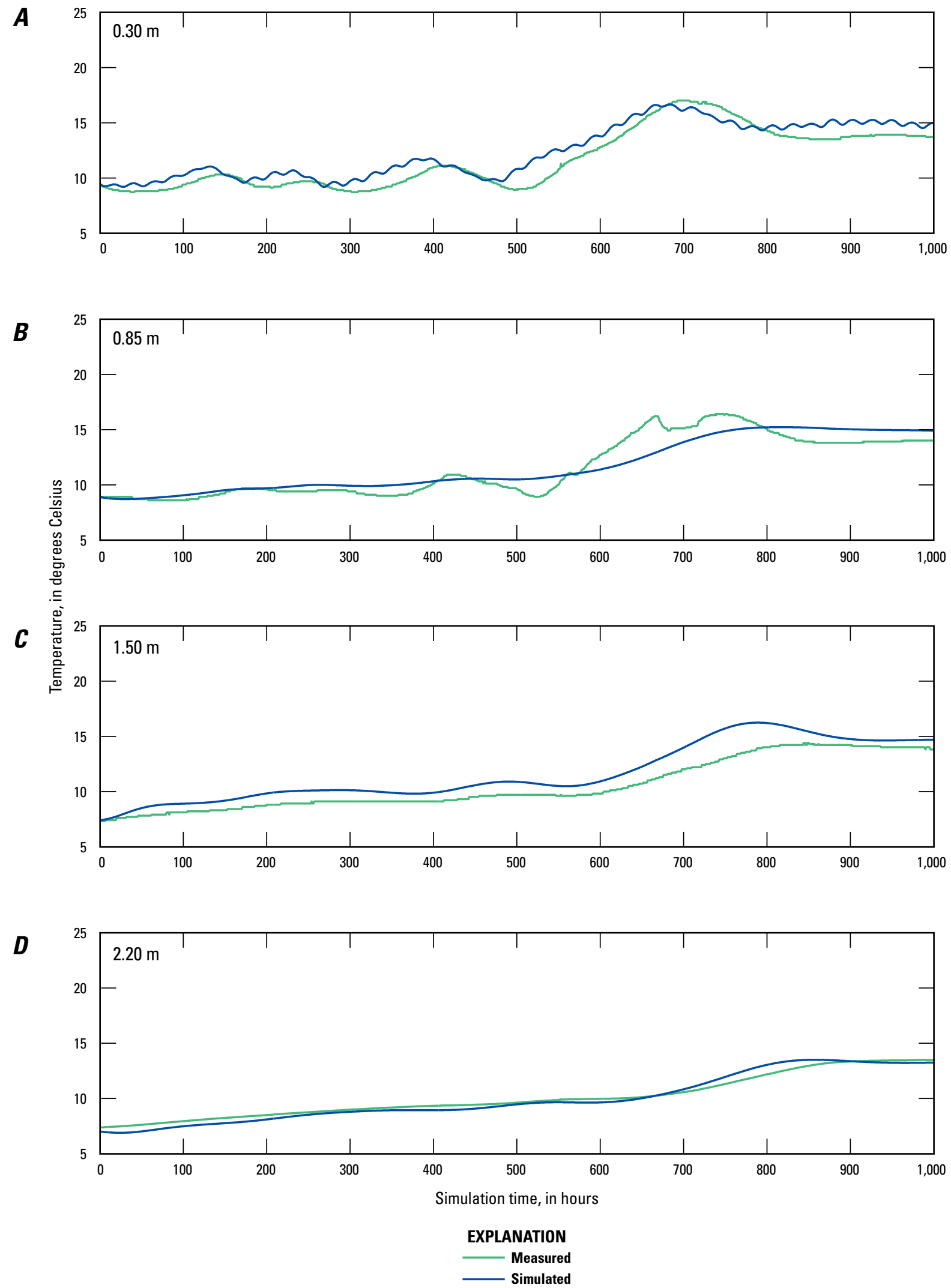

Figure 2C-16. Measured and simulated thermographs for Bank Piezometer 1 (BP1) observations at depths of $A, 0.30 \mathrm{~m}, \mathrm{~B}, 0.85 \mathrm{~m}$, $\mathrm{C}, 1.50 \mathrm{~m}$, and $\mathrm{D}, 2.20 \mathrm{~m}$ for the 2012 calibration period. 

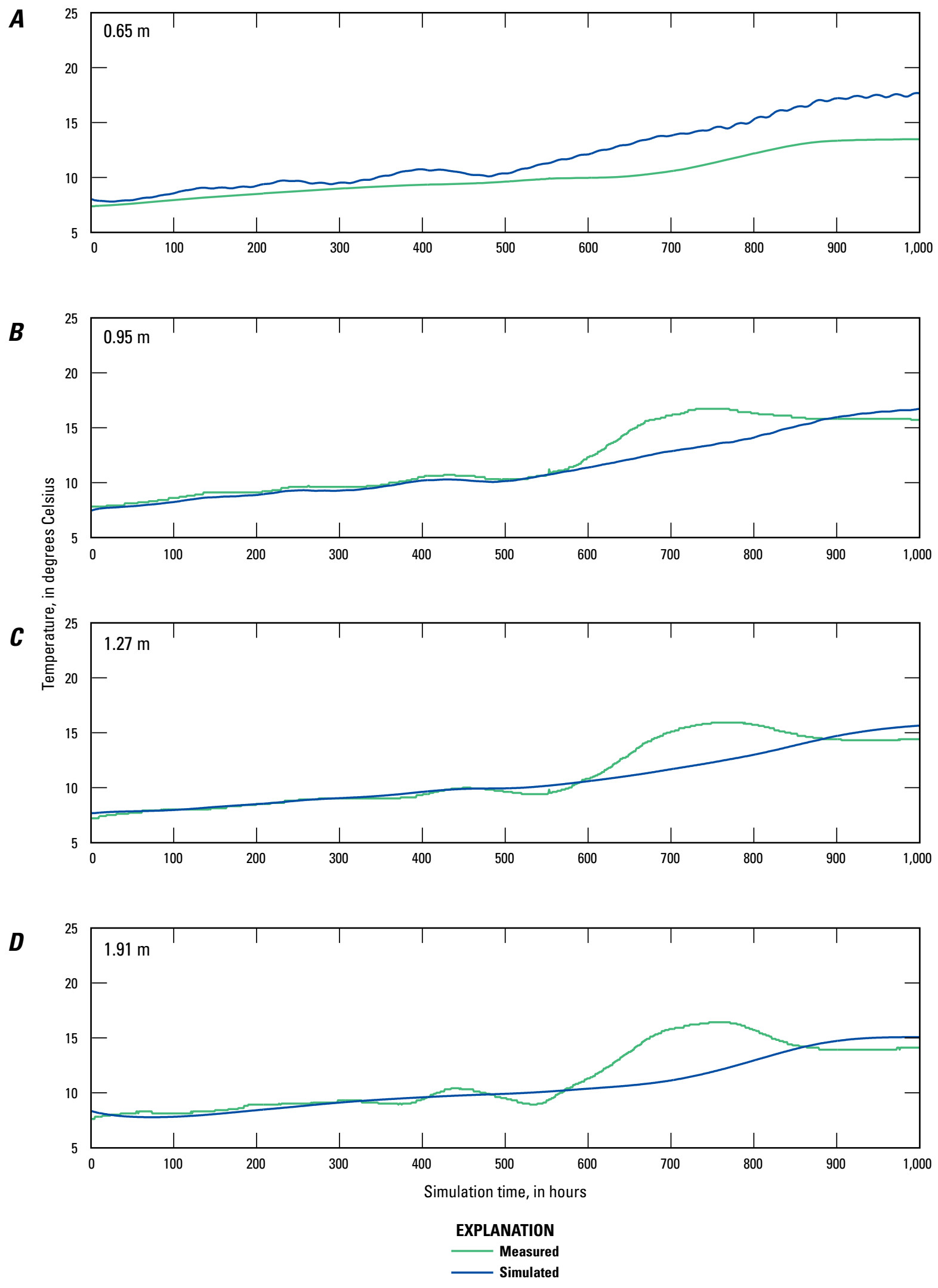

Figure 2C-17. Measured and simulated thermographs for Bank Piezometer 2 (BP2) observations at depths of A, $0.65 \mathrm{~m}, \mathrm{~B}, 0.95 \mathrm{~m}$, $\mathrm{C}, 1.30 \mathrm{~m}$, and $\mathrm{D}, 1.90 \mathrm{~m}$ for the 2012 calibration period. 

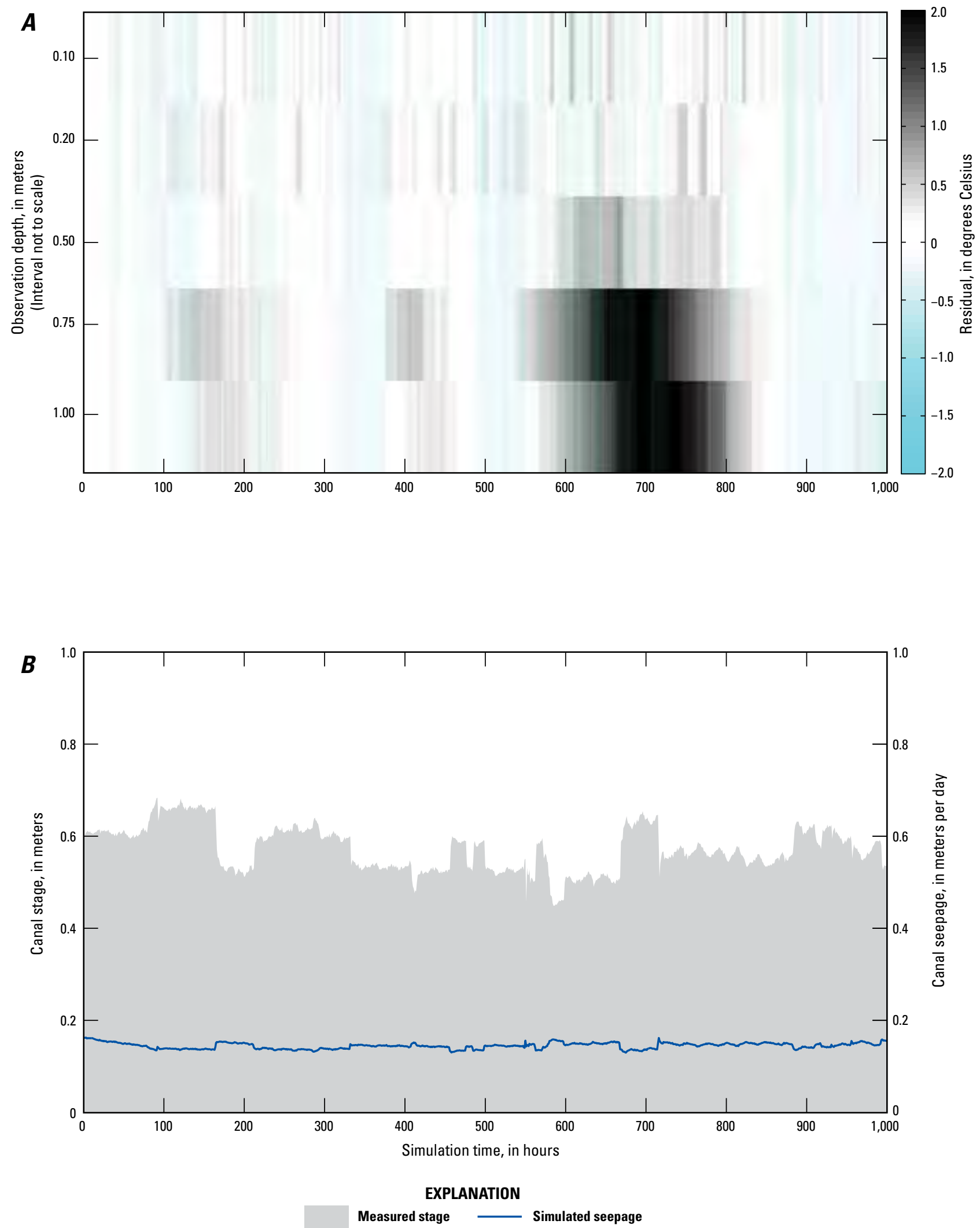

Figure 2C-18. Temperature residual for each depth below the canal at location $A, T 1$, and $B$, measured stage and simulated seepage for the 2012 calibration period. 


\section{Appendix 3A Temperature and Model Results for Schurz 1 Lateral 1 A Canal, Walker Lake Valley, Nevada}

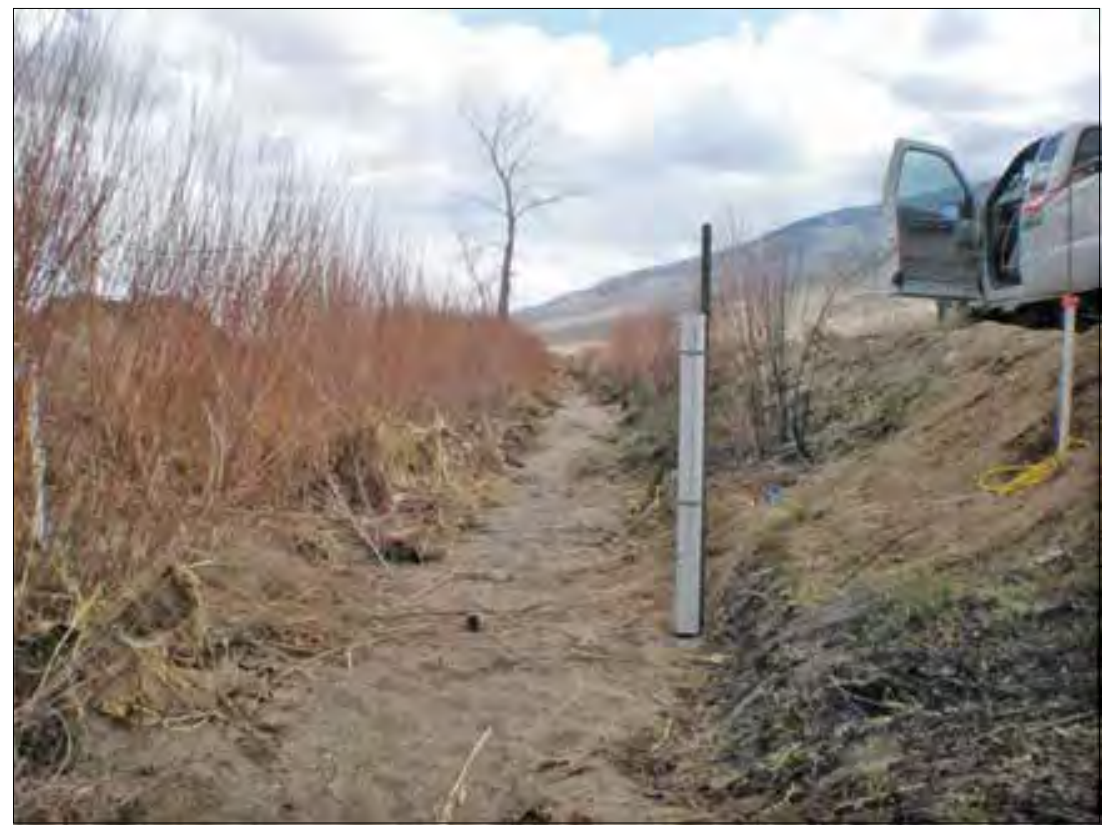

Figure 3A-1. Photograph of SCHURZ 1 LATERAL 1A site, Schurz, Nevada. Photograph taken by David W. Smith, U.S. Geological Survey, looking downstream on 3/26/2013.

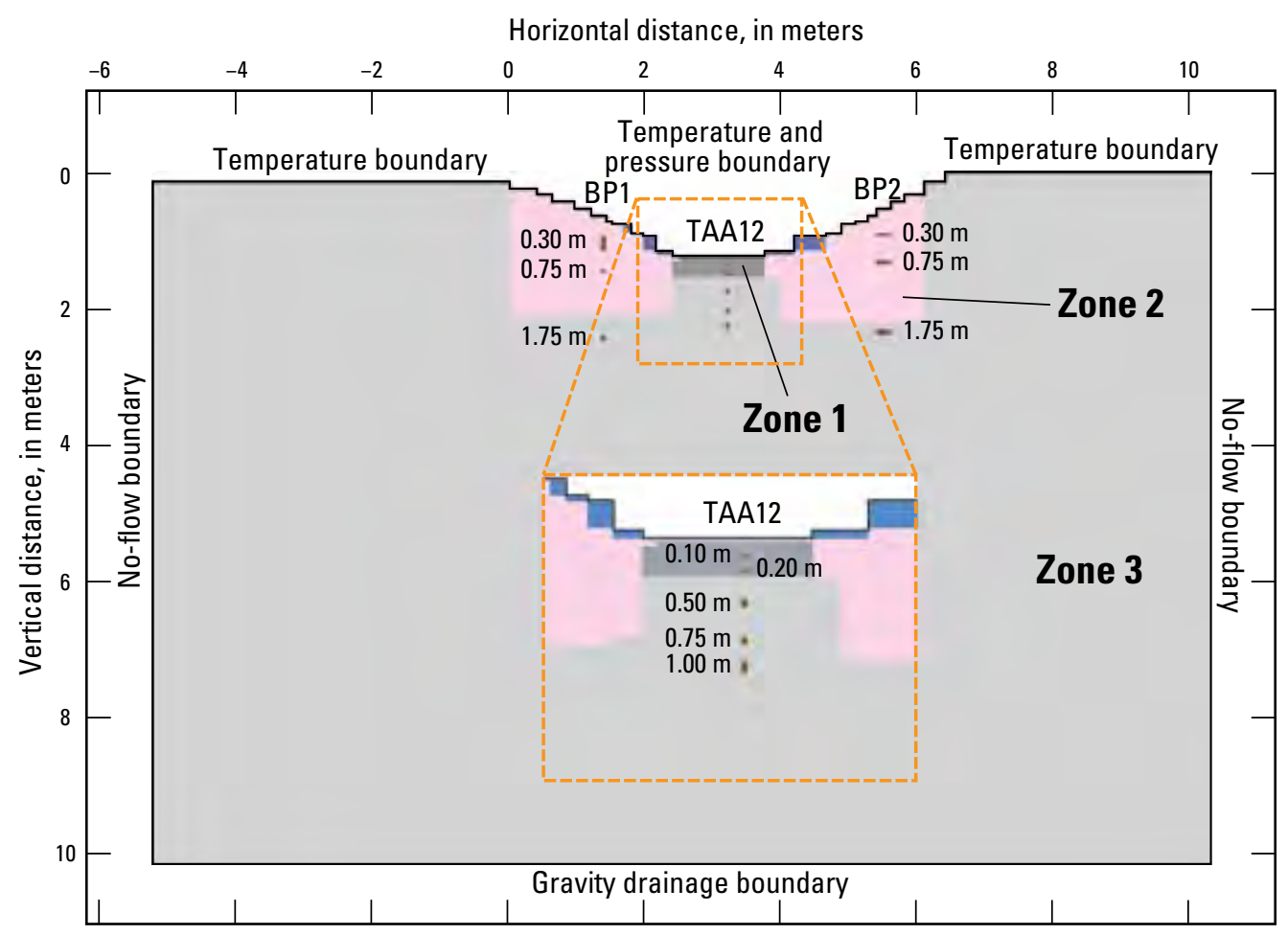

Figure 3A-2. Schematic cross section of two-dimensional VS2DH model of water and heat transport through canal-bed sediments at SCHURZ 1 LATERAL 1A site with soil textural zones (Zones 1-3), locations of temperature observations below ground surface within the canal (TAA12) and along the banks (BP1 and BP2), and specified vertical and horizontal boundary conditions. 

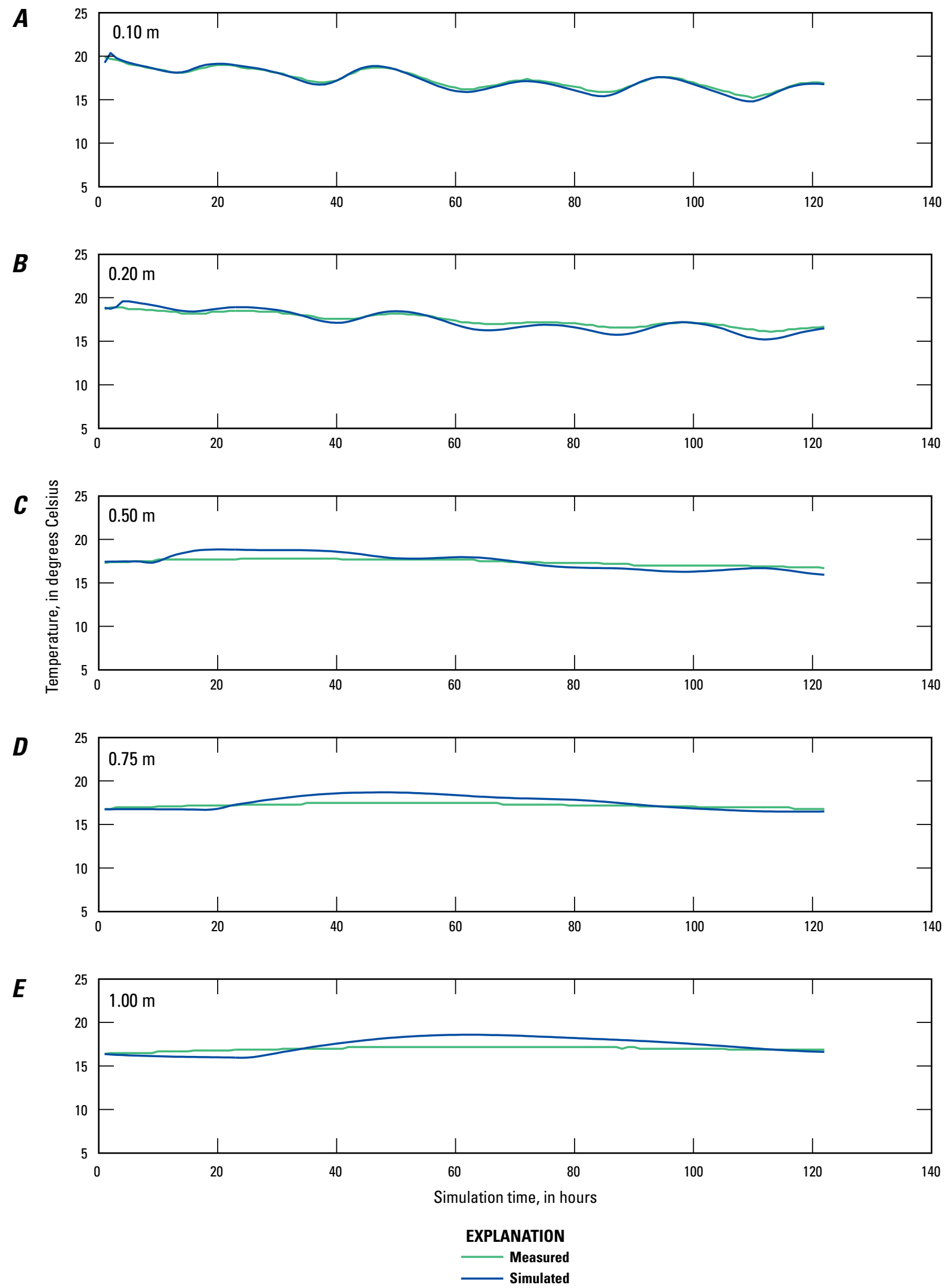

Figure 3A-3. Measured and simulated thermographs for canal sediments for TAA12 at depths of $A, 0.10 \mathrm{~m}, \mathrm{~B}, 0.20 \mathrm{~m}, \mathrm{C}, 0.50 \mathrm{~m}, \mathrm{D}, 0.75 \mathrm{~m}$, and $\mathrm{E}, 1.0 \mathrm{~m}$ for the 2013 calibration period. 

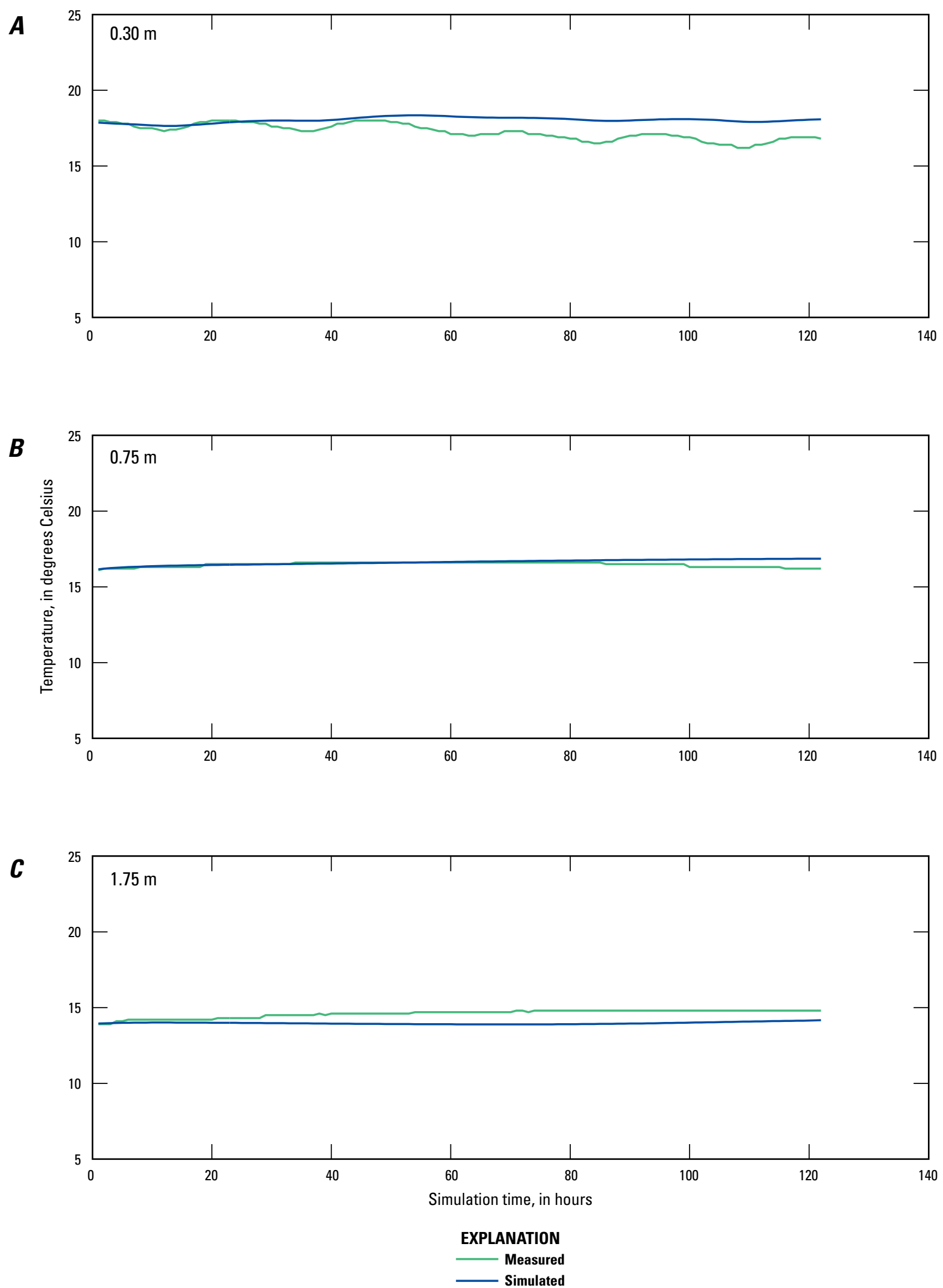

Figure 3A-4. Measured and simulated thermographs at Bank Piezometer 1 (BP1) at depths of $A, 0.30 \mathrm{~m}, \mathrm{~B}, 0.75 \mathrm{~m}$, and $C, 1.75 \mathrm{~m}$ for the 2013 calibration period. 

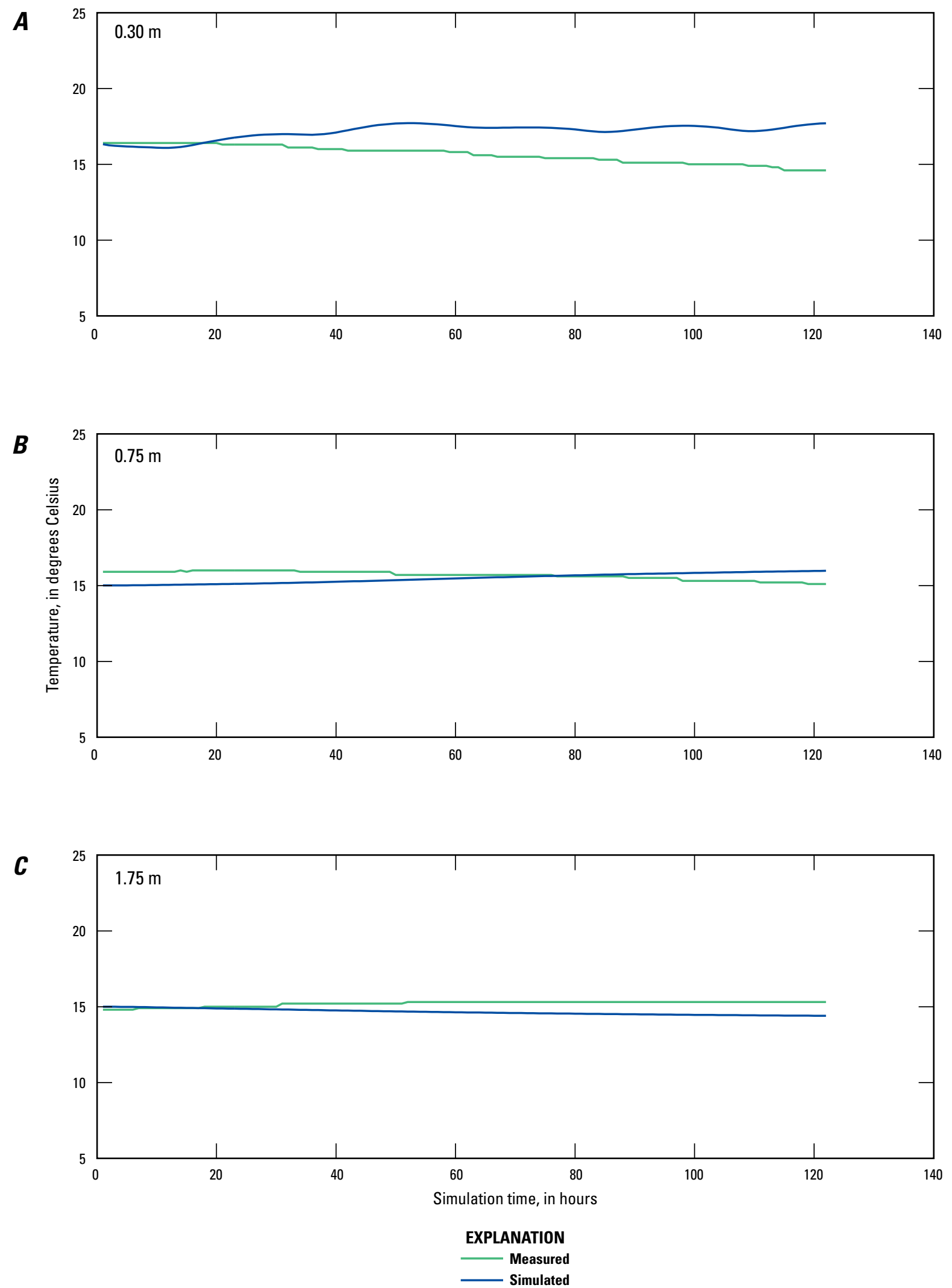

Figure 3A-5. Measured and simulated thermographs at Bank Piezometer 2 (BP2) at depths of $A, 0.30 \mathrm{~m}, \mathrm{~B}, 0.75 \mathrm{~m}$, and $\mathrm{C}, 1.75 \mathrm{~m}$ for the 2013 calibration period. 

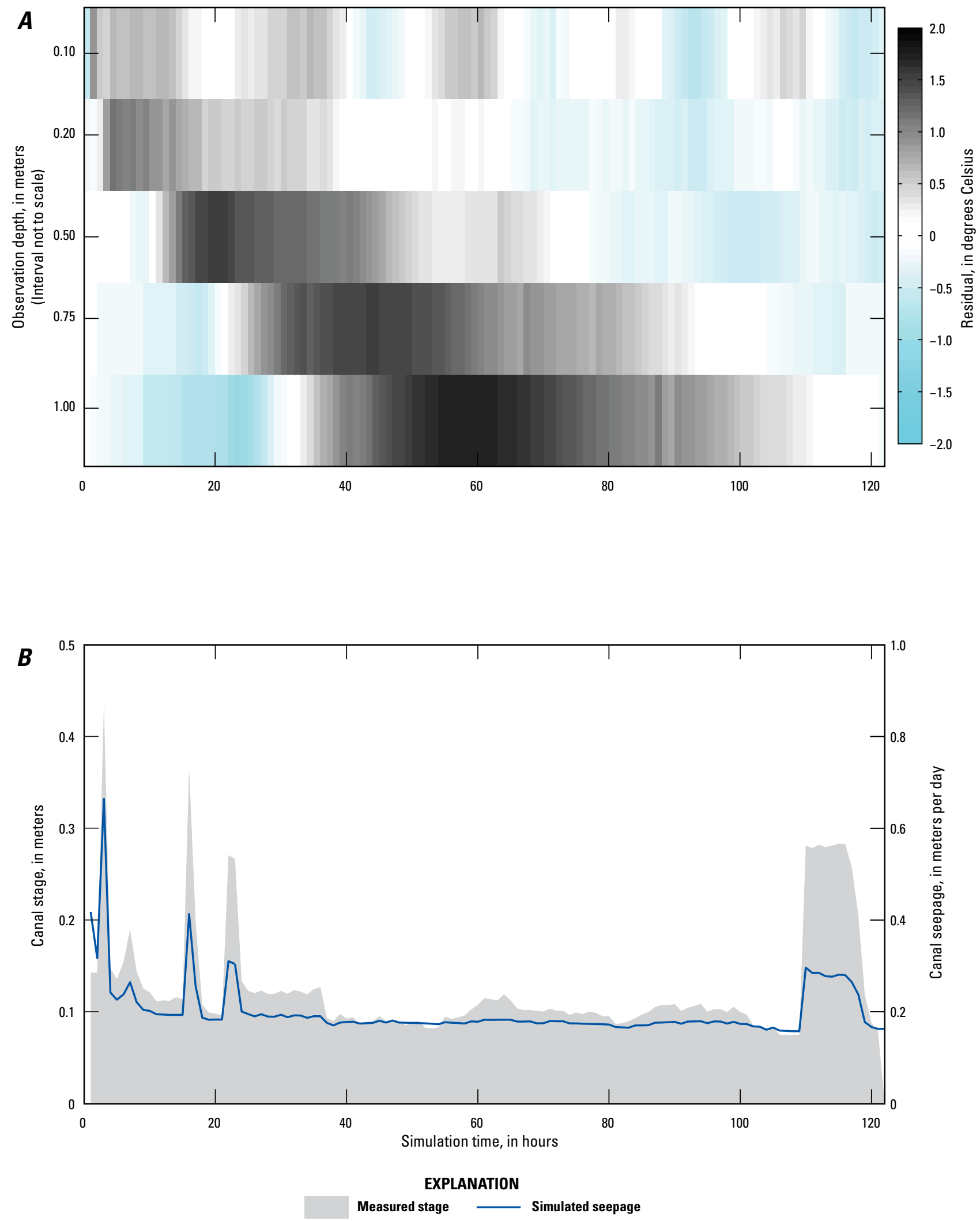

Figure 3A-6. Temperature residual for each depth below the canal at location A, TAA12, and B, measured stage and simulated seepage for the 2013 prediction period. 


\section{Appendix 3A Temperature and Model Results for Schurz2 Lateral 1 A Canal, Walker Lake Valley, Nevada}

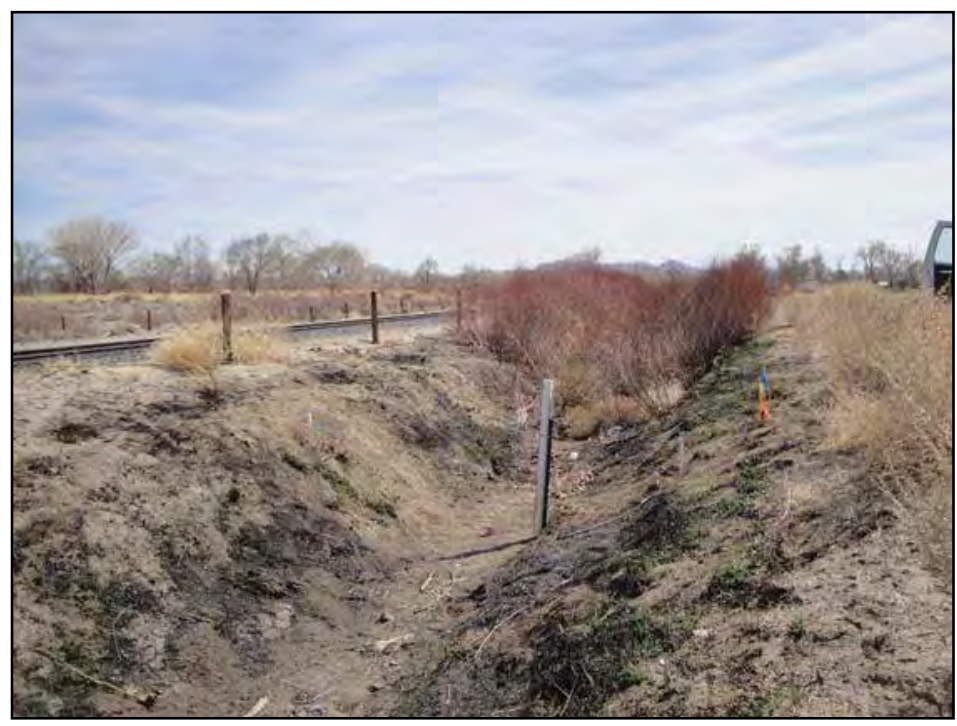

Figure 3A-7. Photograph of SCHURZ 2 LATERAL 1A site, Schurz, Nevada. Photograph taken by David W. Smith, U.S. Geological Survey, looking downstream on 3/26/2013.

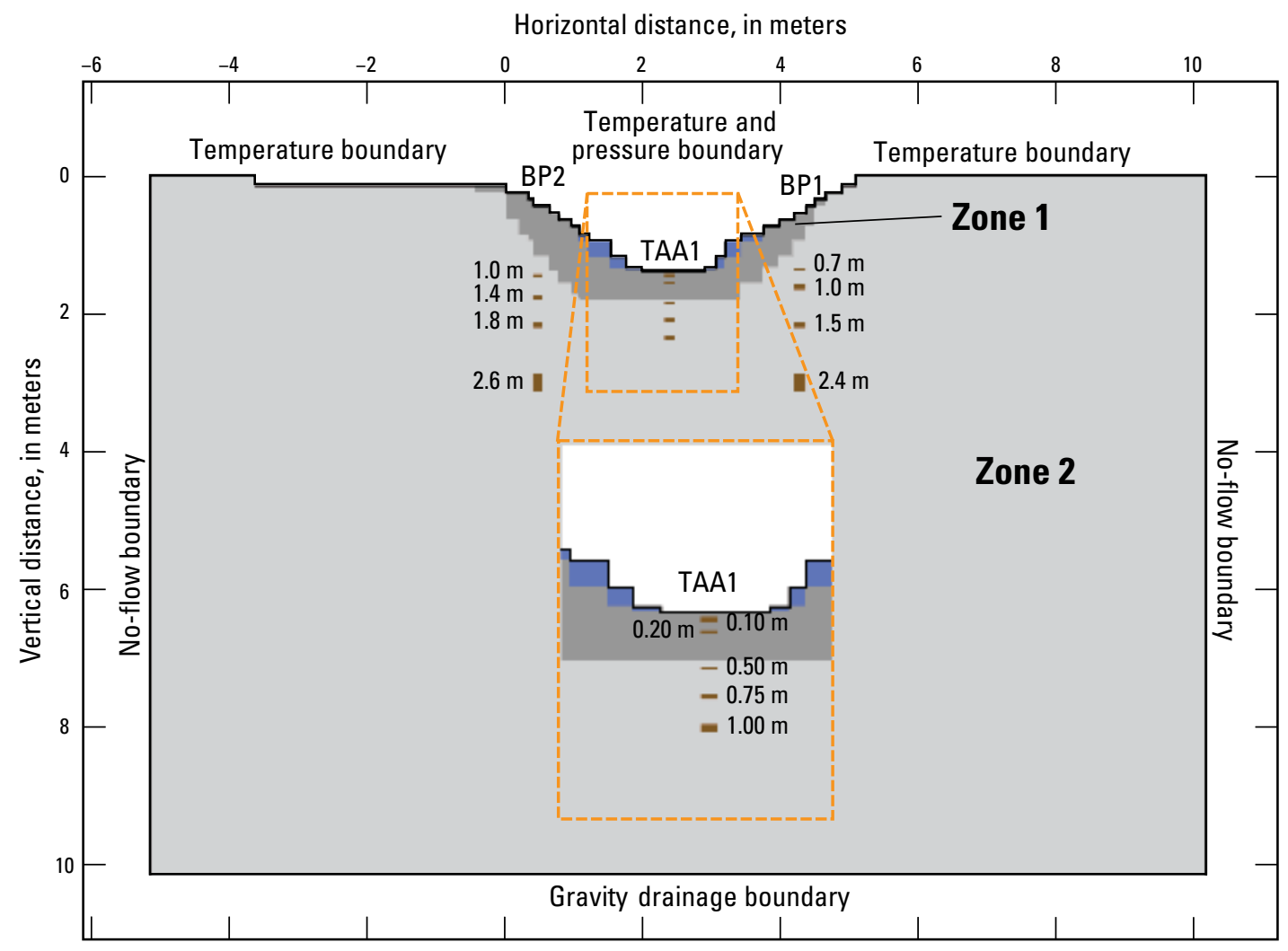

Figure 3A-8. Schematic cross section of two-dimensional VS2DH model of water and heat transport through canal-bed sediments at SCHURZ 2 LATERAL 1A site with soil textural zones (Zones 1-2), locations of observations below ground surface within the canal (TAA1) and along the banks (BP1 and BP2), and specified vertical and horizontal boundary conditions. 

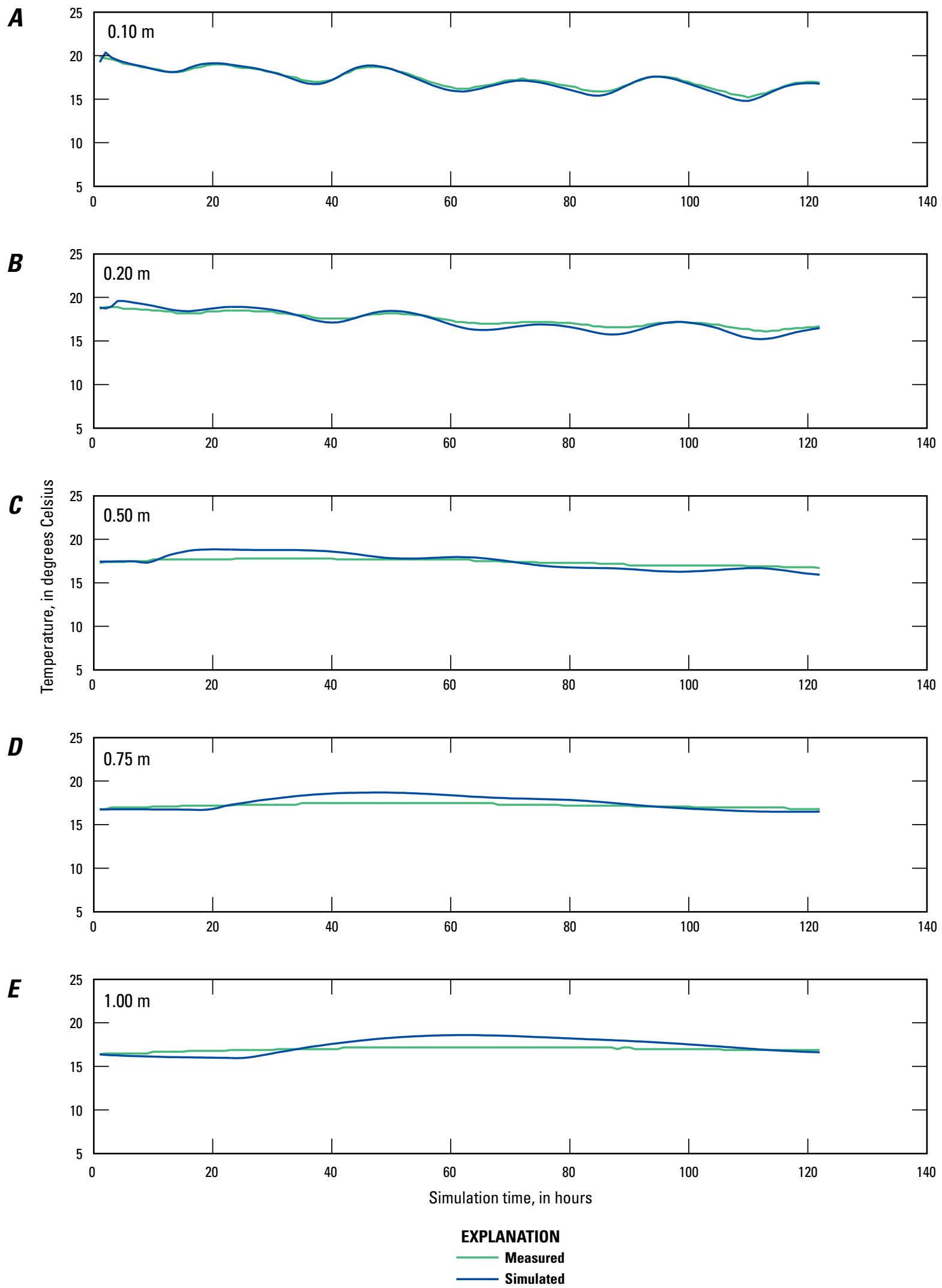

Figure 3A-9. Measured and simulated thermographs for canal sediments for TAA1 at depths of A, 0.10 m, B, 0.20 m, C, 0.50 m, D, $0.75 \mathrm{~m}$, and $\mathrm{E}, 1.0 \mathrm{~m}$ for the 2013 calibration period. 

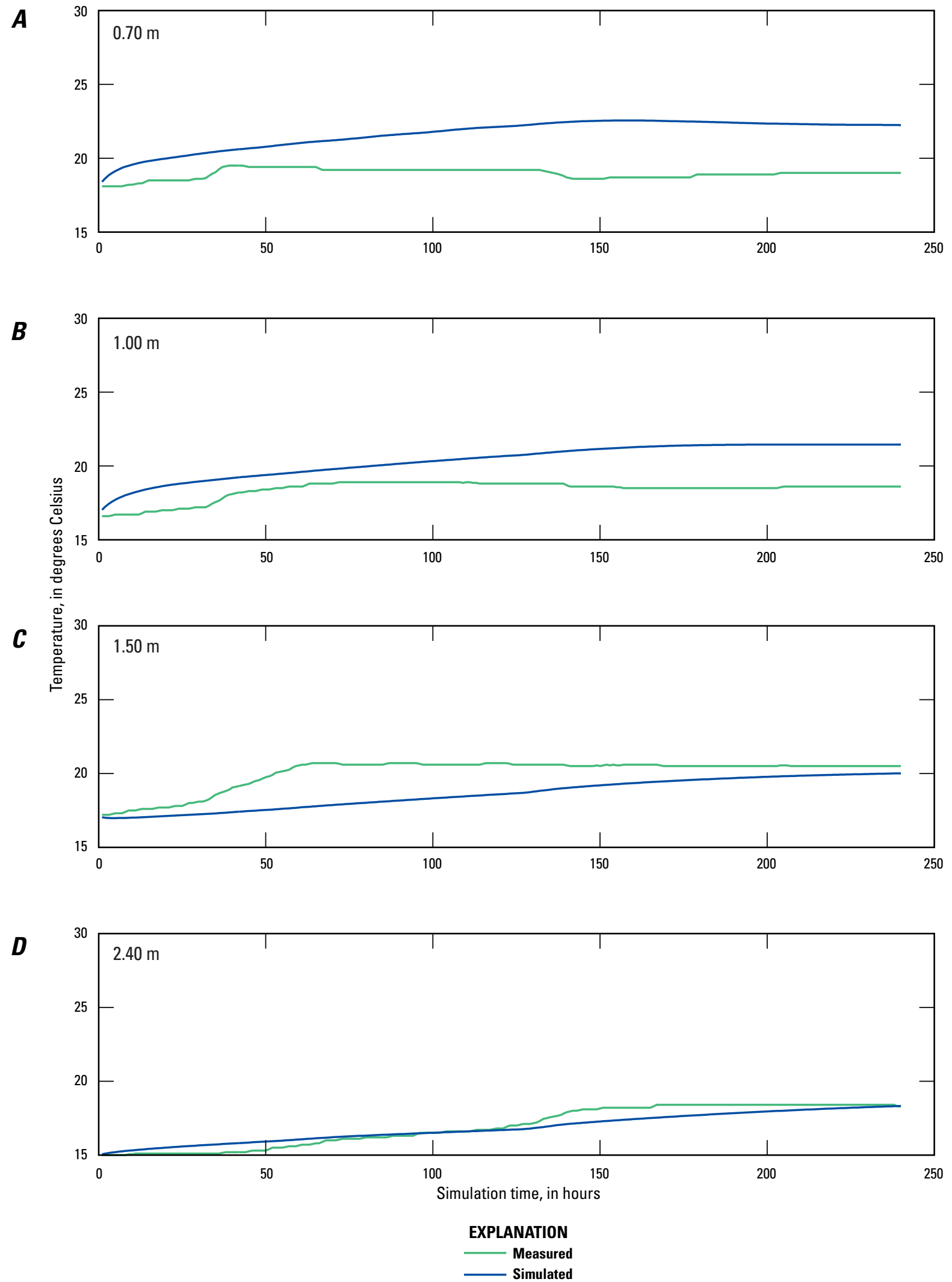

Figure 3A-10. Measured and simulated thermographs for canal sediments for Bank Piezometer 1 (BP1) at depths of $A, 0.70 \mathrm{~m}, \mathrm{~B}, 1.0 \mathrm{~m}$, $\mathrm{C}, 1.50 \mathrm{~m}$, and $\mathrm{D}, 2.40 \mathrm{~m}$ for the 2013 calibration period. 

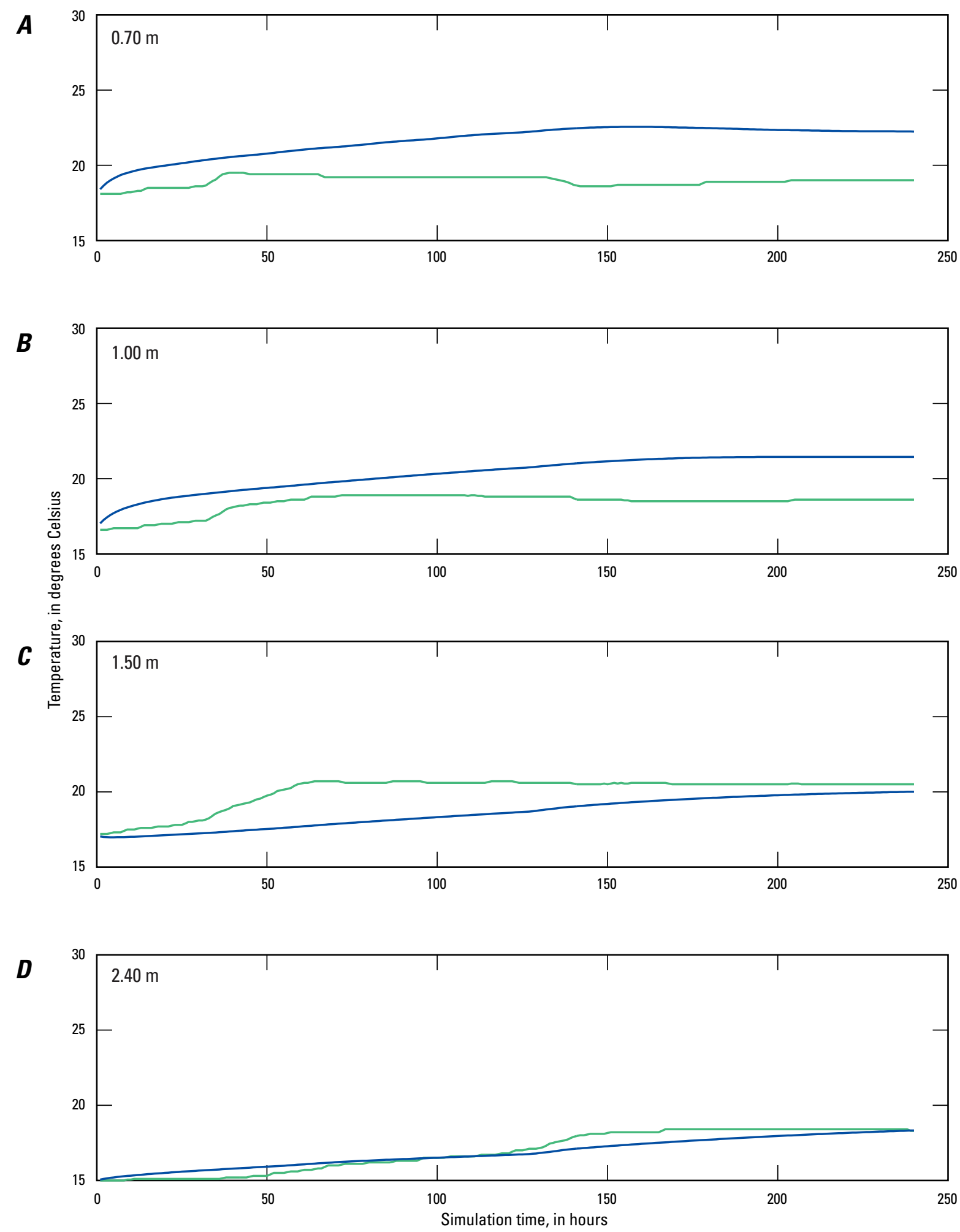

EXPLANATION

Measured

_ Simulated

Figure 3A-11. Measured and simulated thermographs for canal sediments for Bank Piezometer 2 (BP2) at depths of $A, 1.0 \mathrm{~m}, \mathrm{~B}, 1.40 \mathrm{~m}$, C, $1.80 \mathrm{~m}$, and D, $2.60 \mathrm{~m}$ for the 2013 calibration period. 

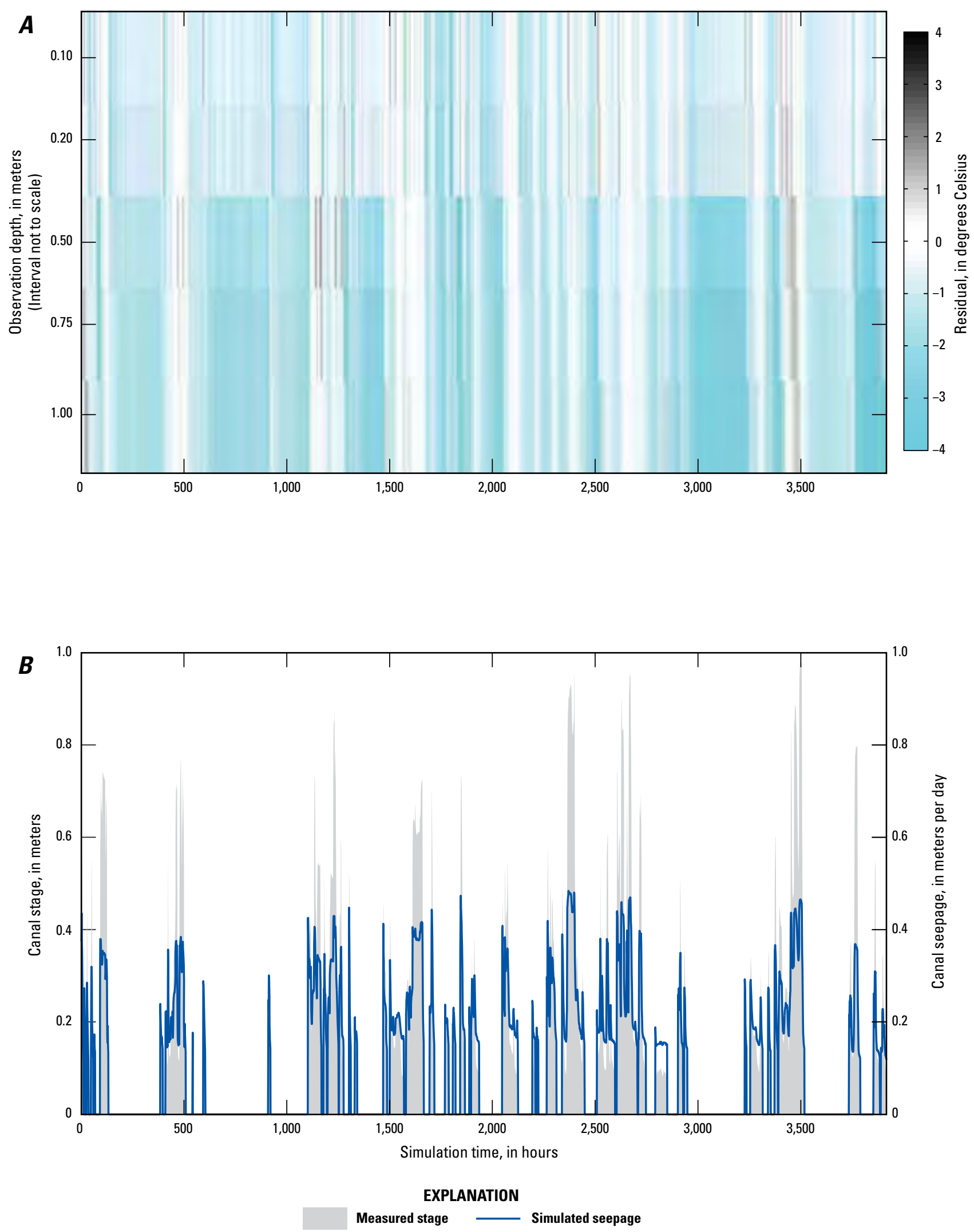

Figure 3A-12. Temperature residual for each depth below the canal at location $A, T A A 1$, and $B$, measured stage and simulated seepage for the 2013 prediction period. 


\section{Appendix 3B Temperature and Model Results for Schurz 3 Lateral 2A Canal, Walker Lake Valley, Nevada}

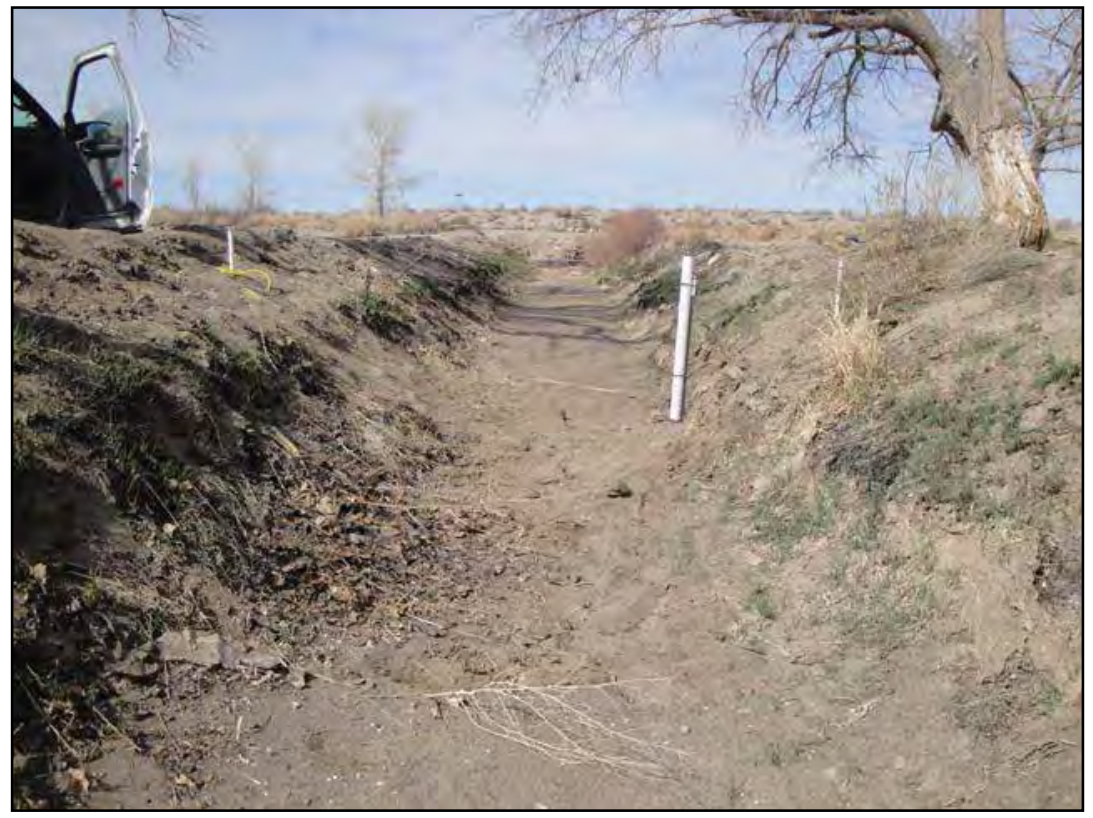

Figure 3B-1. Photograph of SCHURZ 3 LATERAL 2A site, Schurz, Nevada. Photograph taken by David W. Smith, U.S. Geological Survey, looking downstream on 3/26/2013.

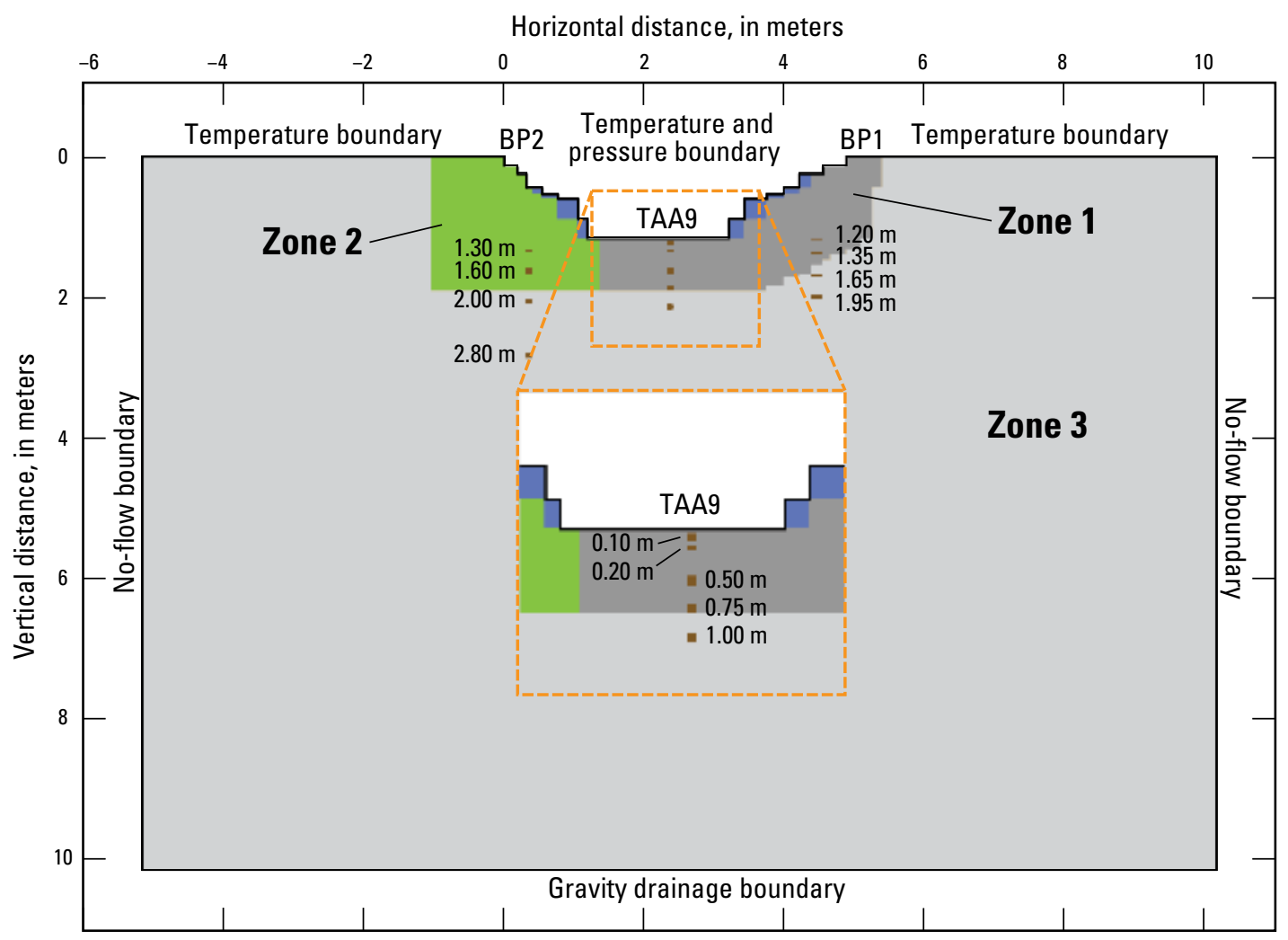

Figure 3B-2. Schematic cross section of two-dimensional VS2DH model of water and heat transport through canal-bed sediments at SCHURZ 3 LATERAL 2A site with soil textural zones (Zones 1-3), locations of temperature observations below ground surface within the canal (TAA9) and along the banks (BP1 and BP2), and specified vertical and horizontal boundary conditions. 

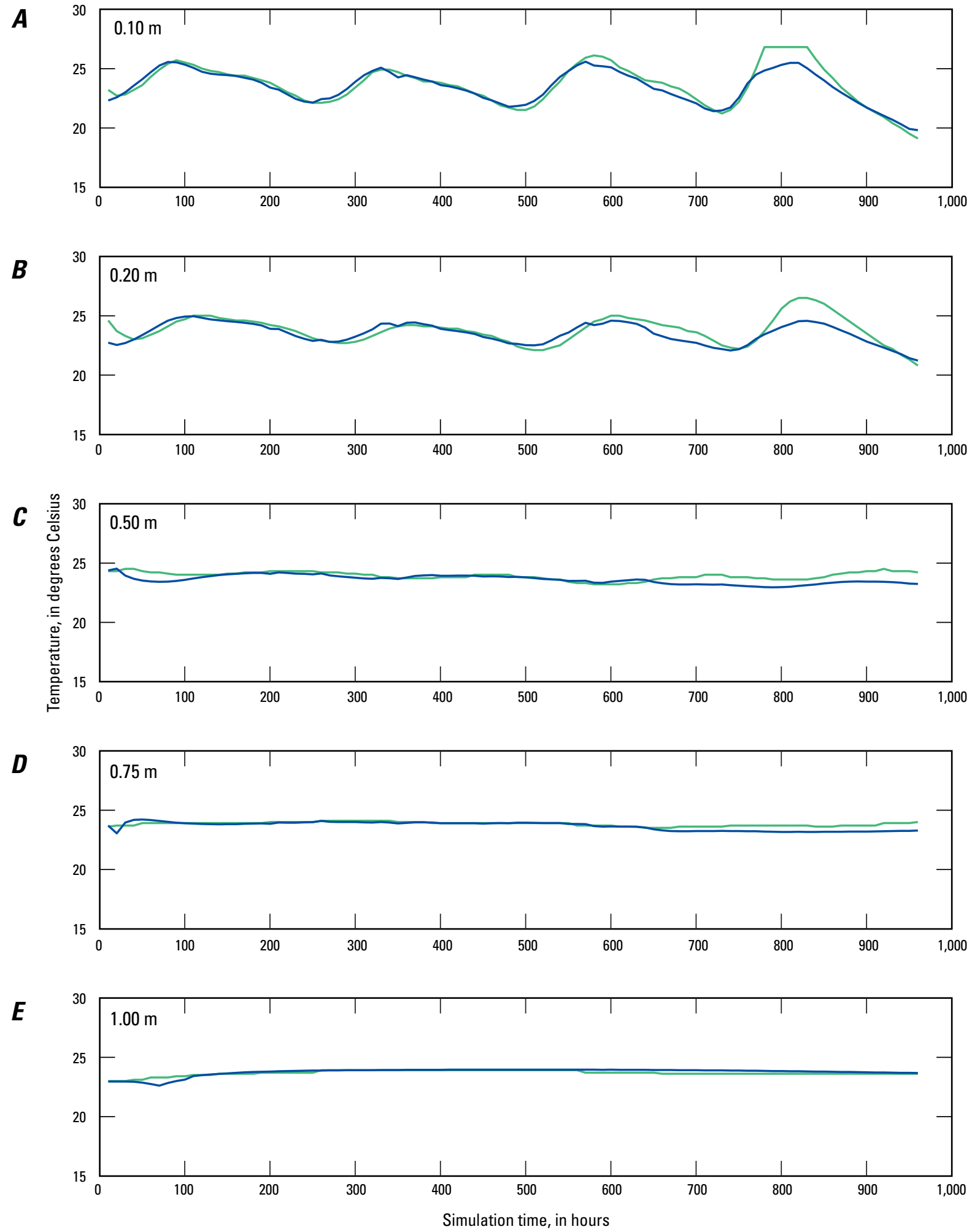

EXPLANATION

Measured

Simulated

Figure 3B-3. Measured and simulated thermographs for canal sediments for TAA9 at depths of $A, 0.10 \mathrm{~m}, \mathrm{~B}, 0.20 \mathrm{~m}, \mathrm{C}, 0.50 \mathrm{~m}, \mathrm{D}, 0.75 \mathrm{~m}$, and $\mathrm{E}, 1.0 \mathrm{~m}$ for the 2013 calibration period. 

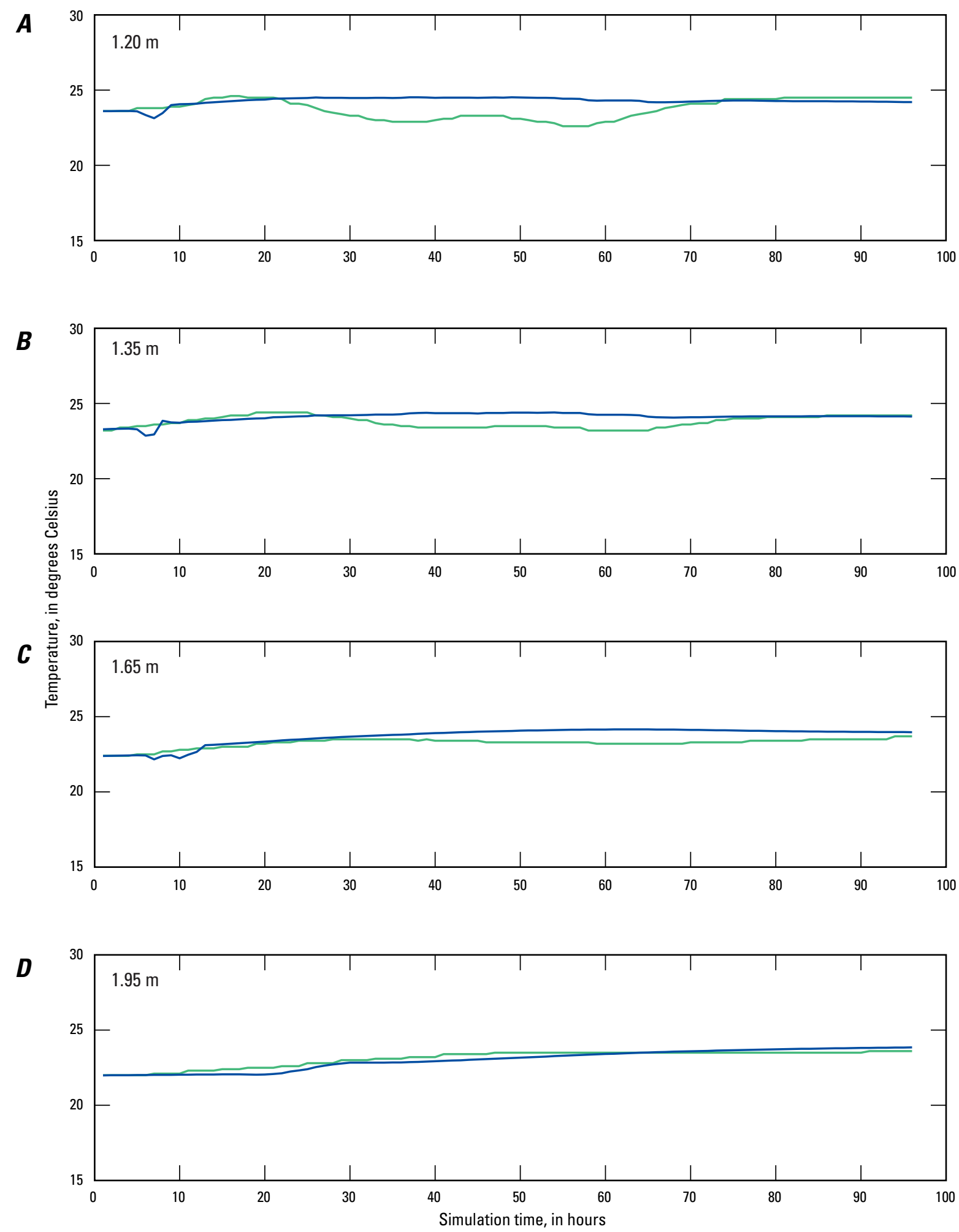

EXPLANATION

Measured

Simulated

Figure 3B-4. Measured and simulated thermographs for canal sediments for Bank Piezometer 1 (BP1) at depths of A, $1.20 \mathrm{~m}, \mathrm{~B}, 1.35 \mathrm{~m}$, $\mathrm{C}, 1.65 \mathrm{~m}$, and $\mathrm{D}, 1.95 \mathrm{~m}$ for the 2013 calibration period. 

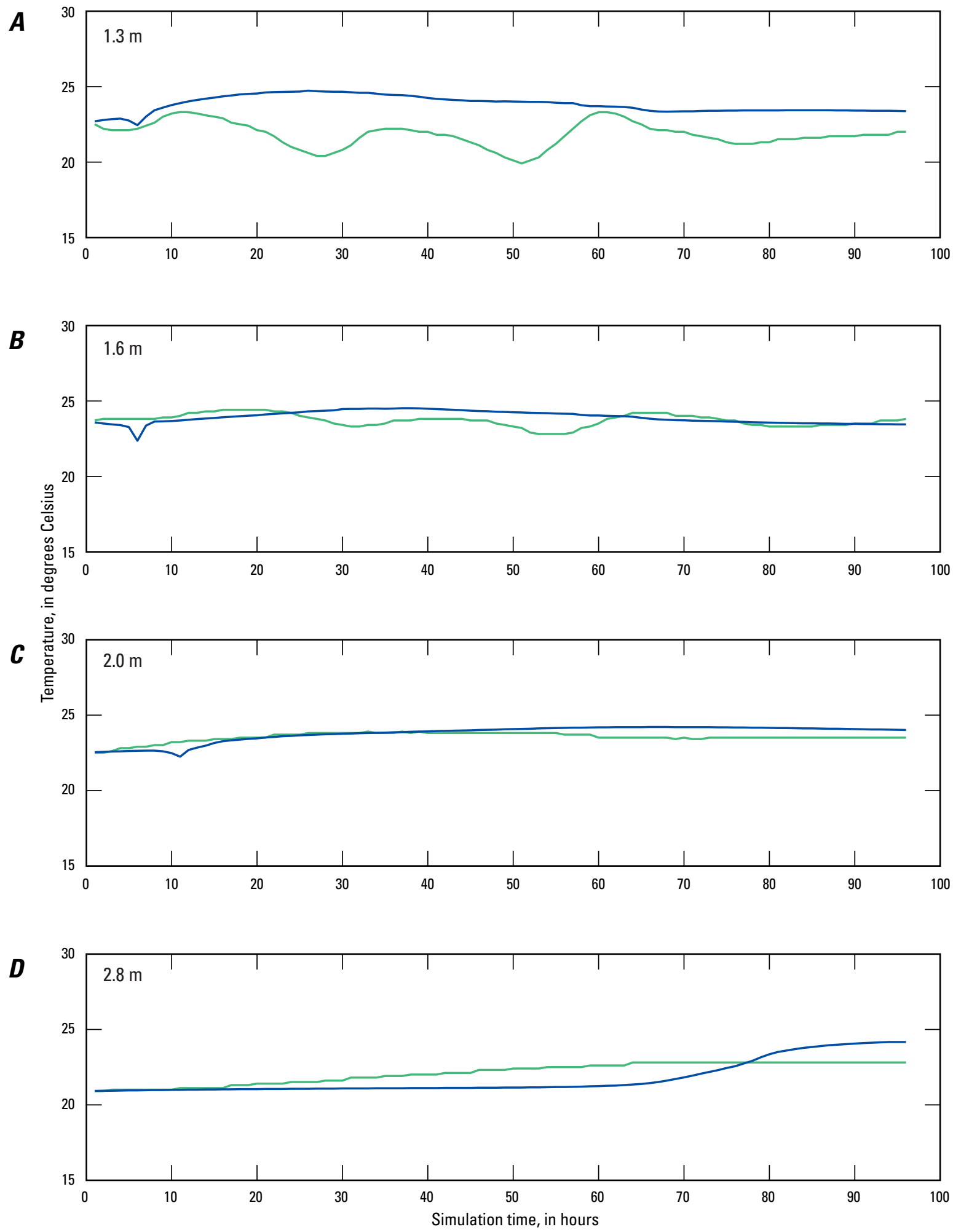

EXPLANATION

Measured

Simulated

Figure 3B-5. Measured and simulated thermographs for canal sediments for Bank Piezometer 2 (BP2) at depths of $A, 1.30 \mathrm{~m}, \mathrm{~B}, 1.60 \mathrm{~m}$, C, $2.0 \mathrm{~m}$, and $\mathrm{D}, 2.80 \mathrm{~m}$ for the 2013 calibration period. 

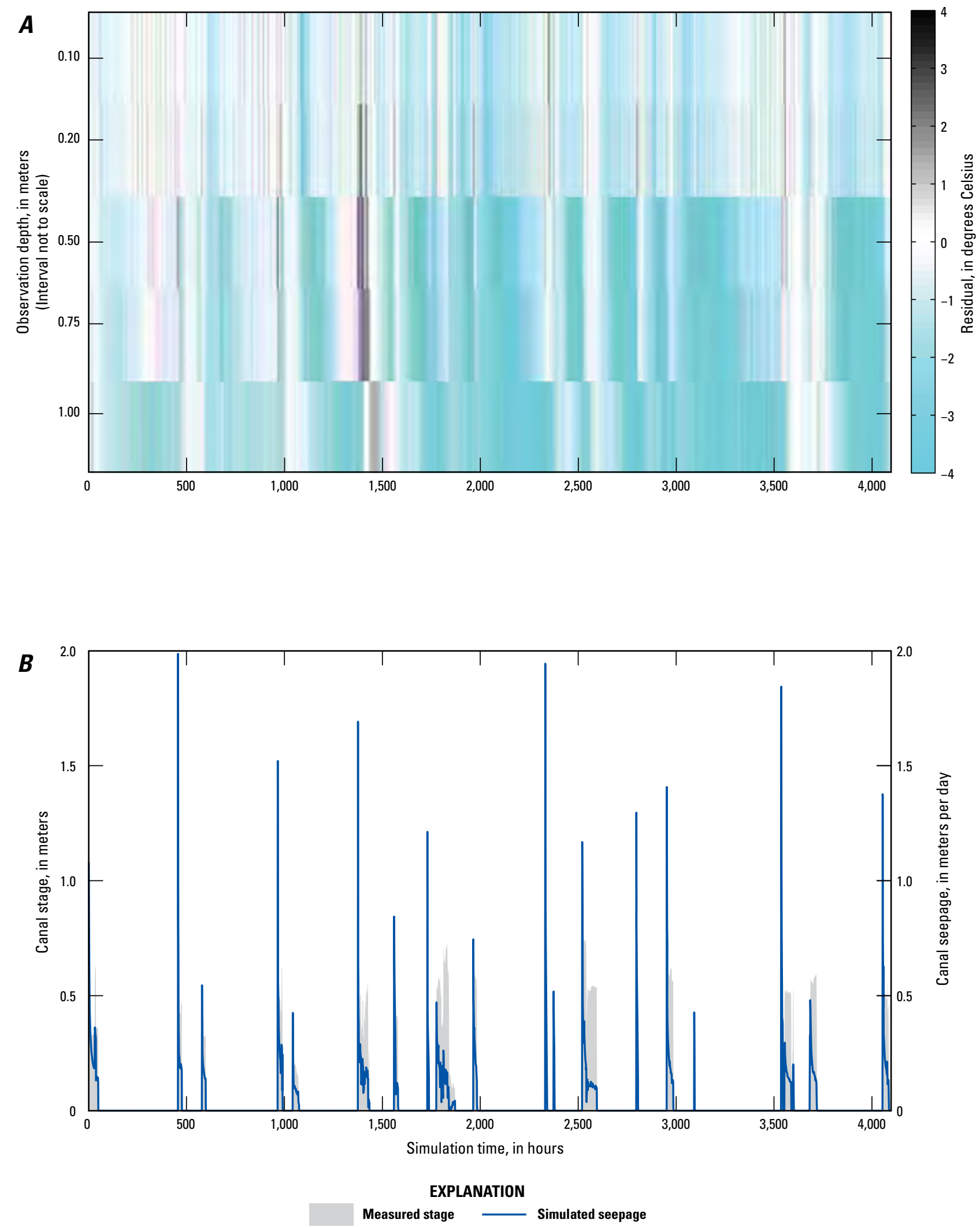

Figure 3B-6. Temperature residual for each depth below the canal at location A, TAA9, and B, measured stage and simulated seepage for the 2013 prediction period. 


\section{Appendix 3C Temperature and Model Results for Schurz 4 Canal 2, Walker Lake Valley, Nevada}

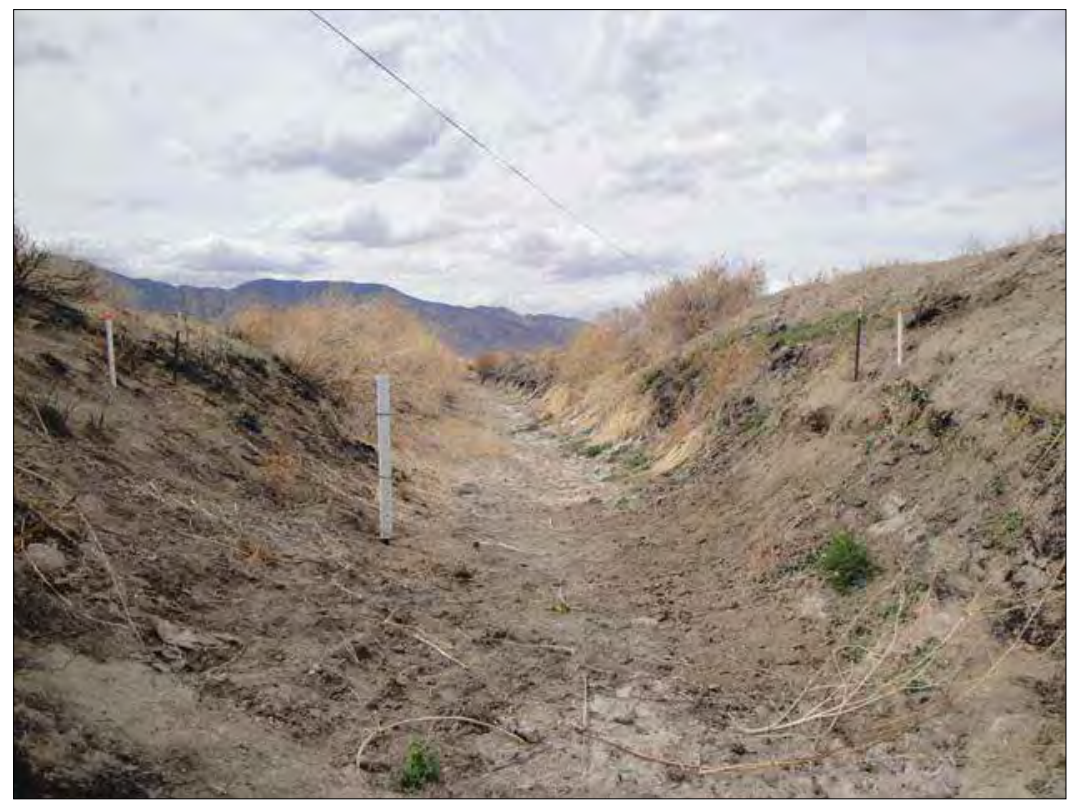

Figure 3C-1. Photograph of SCHURZ 4 CANAL 2 site, Schurz, Nevada. Photograph taken by David W. Smith, U.S. Geological Survey, looking upstream on 3/27/2013.

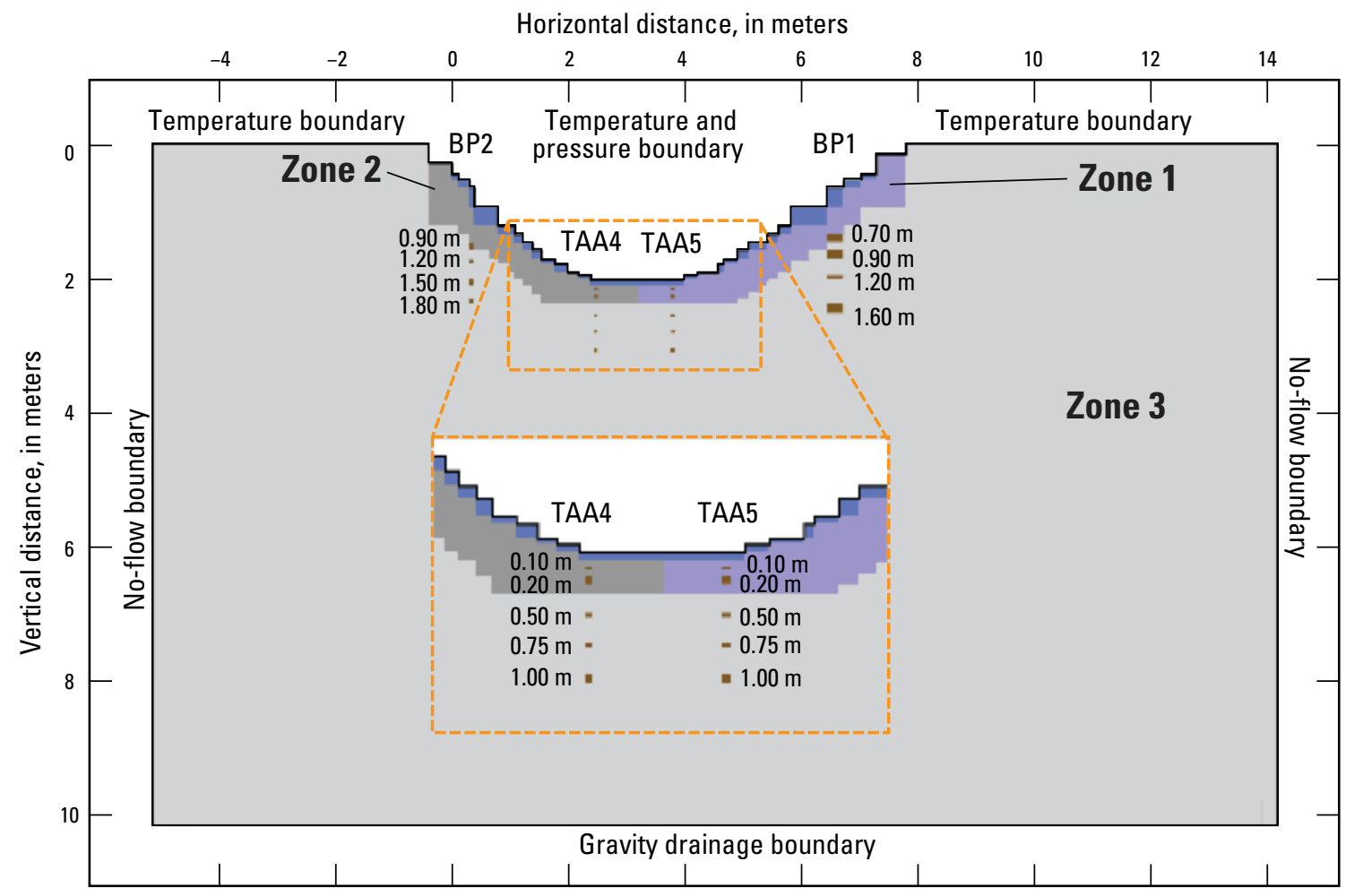

Figure 3C-2. Schematic cross section of two-dimensional VS2DH model of water and heat transport through canal-bed sediments at SCHURZ 4 CANAL 2 site with soil textural zones (Zones 1-3), locations of temperature observations below ground surface within the canal (TAA4 and TAA5) and along the banks (BP1 and BP2), and specified vertical and horizontal boundary conditions. 

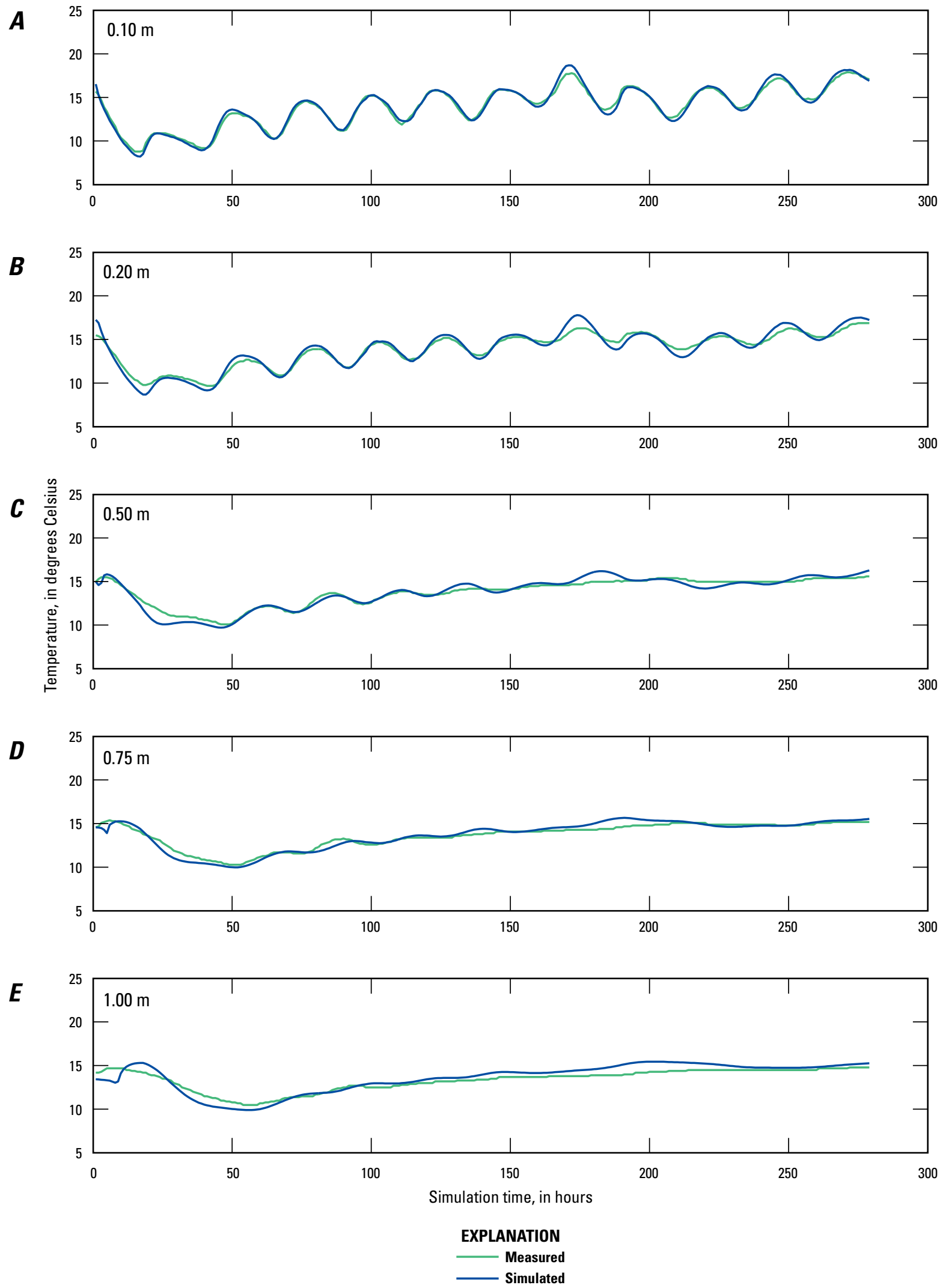

Figure 3C-3. Measured and simulated thermographs for canal sediments for TAA4 at depths of A, $0.10 \mathrm{~m}, \mathrm{~B}, 0.20 \mathrm{~m}, \mathrm{C}, 0.50 \mathrm{~m}, \mathrm{D}, 0.75 \mathrm{~m}$, and $\mathrm{E}, 1.0 \mathrm{~m}$ for the 2013 calibration period. 

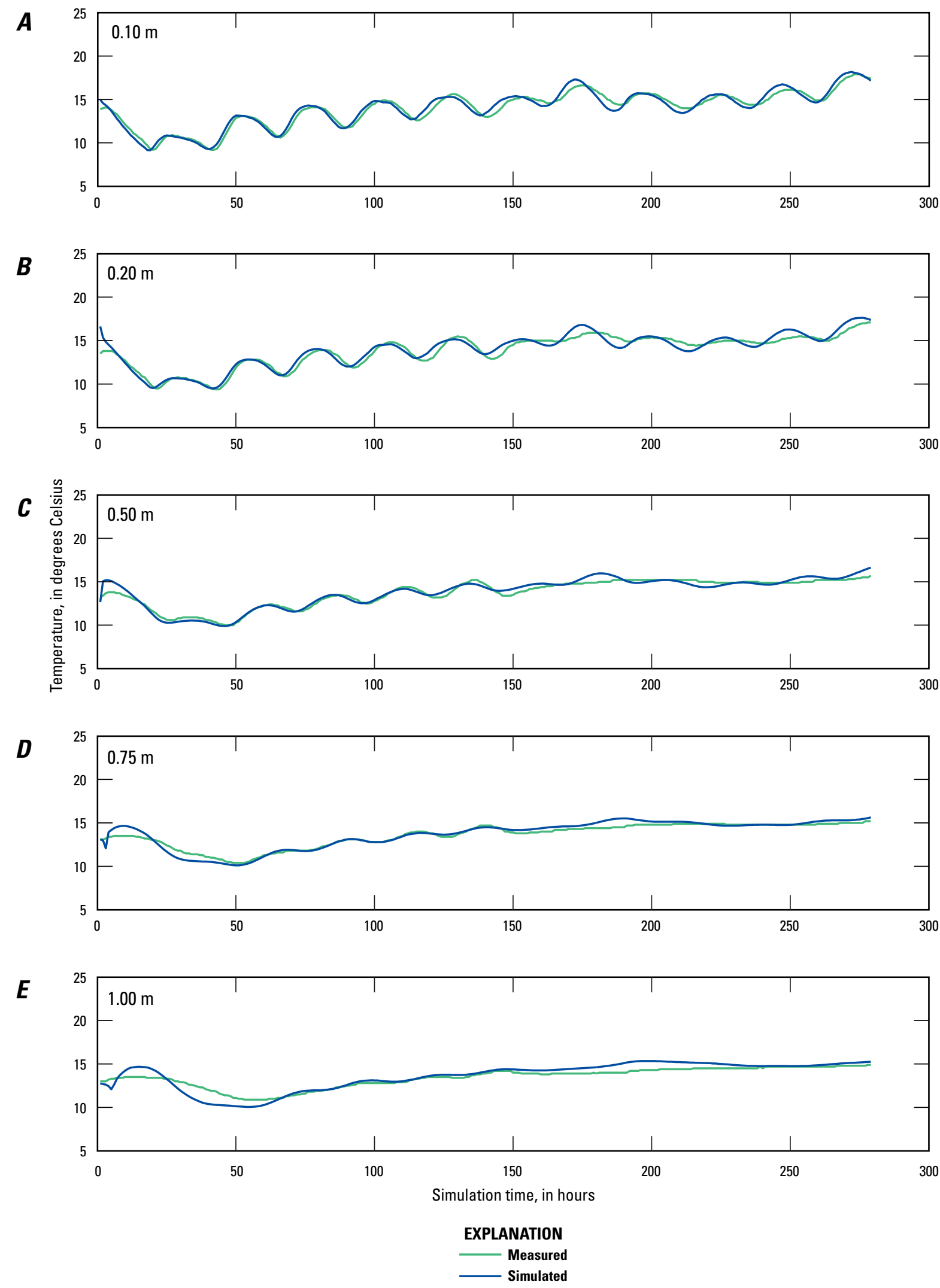

Figure 3C-4. Measured and simulated thermographs for canal sediments for TAA5 at depths of $A, 0.10 \mathrm{~m}, \mathrm{~B}, 0.20 \mathrm{~m}, \mathrm{C}, 0.50 \mathrm{~m}, \mathrm{D}, 0.75 \mathrm{~m}$, and $\mathrm{E}, 1.0 \mathrm{~m}$ for the 2013 calibration period. 

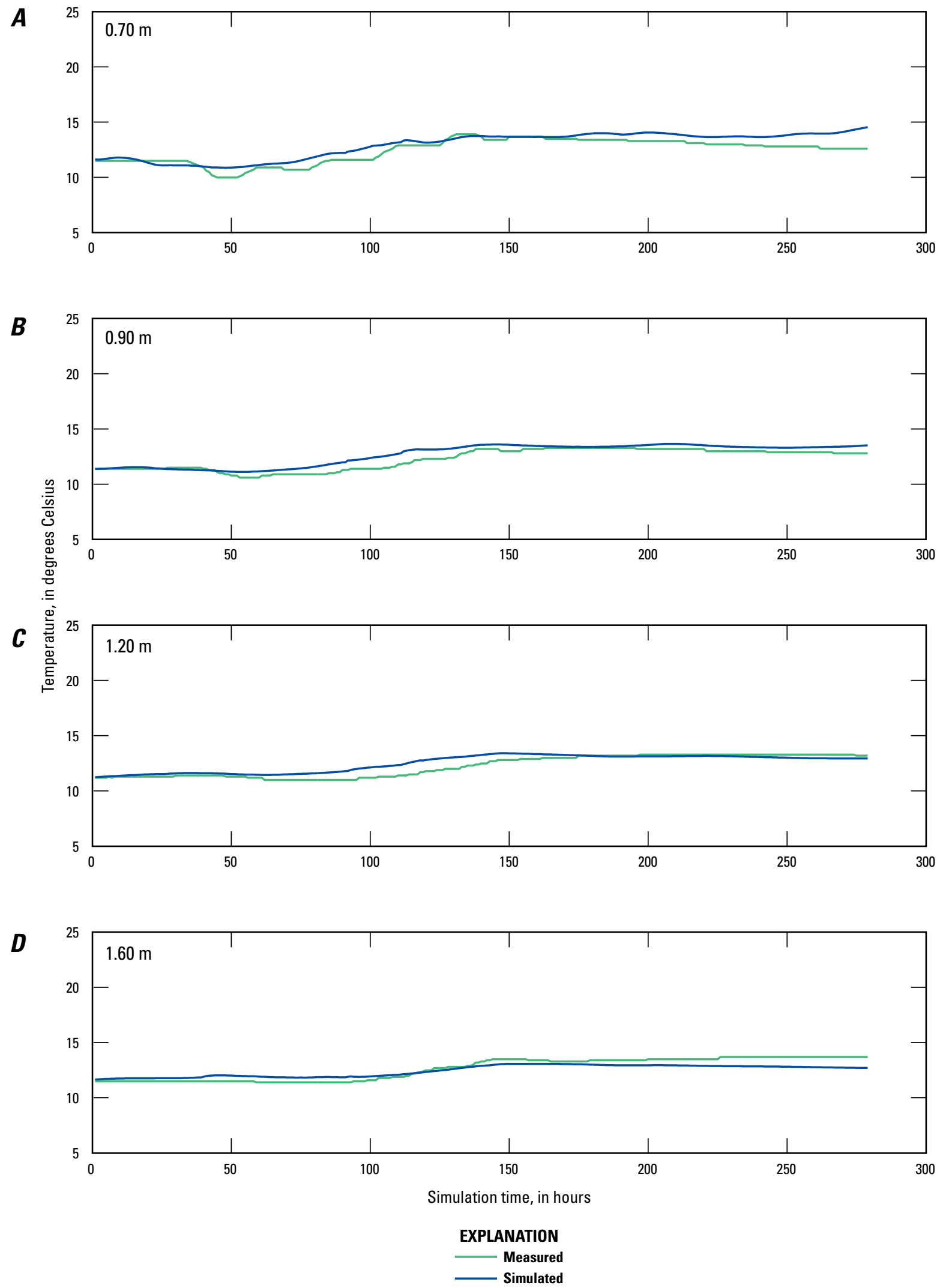

Figure 3C-5. Measured and simulated thermographs for canal sediments for Bank Piezometer 1 (BP1) at depths of $A, 0.70 \mathrm{~m}, \mathrm{~B}, 0.90 \mathrm{~m}$, C, $1.20 \mathrm{~m}$, and D, $1.60 \mathrm{~m}$ for the 2013 calibration period. 

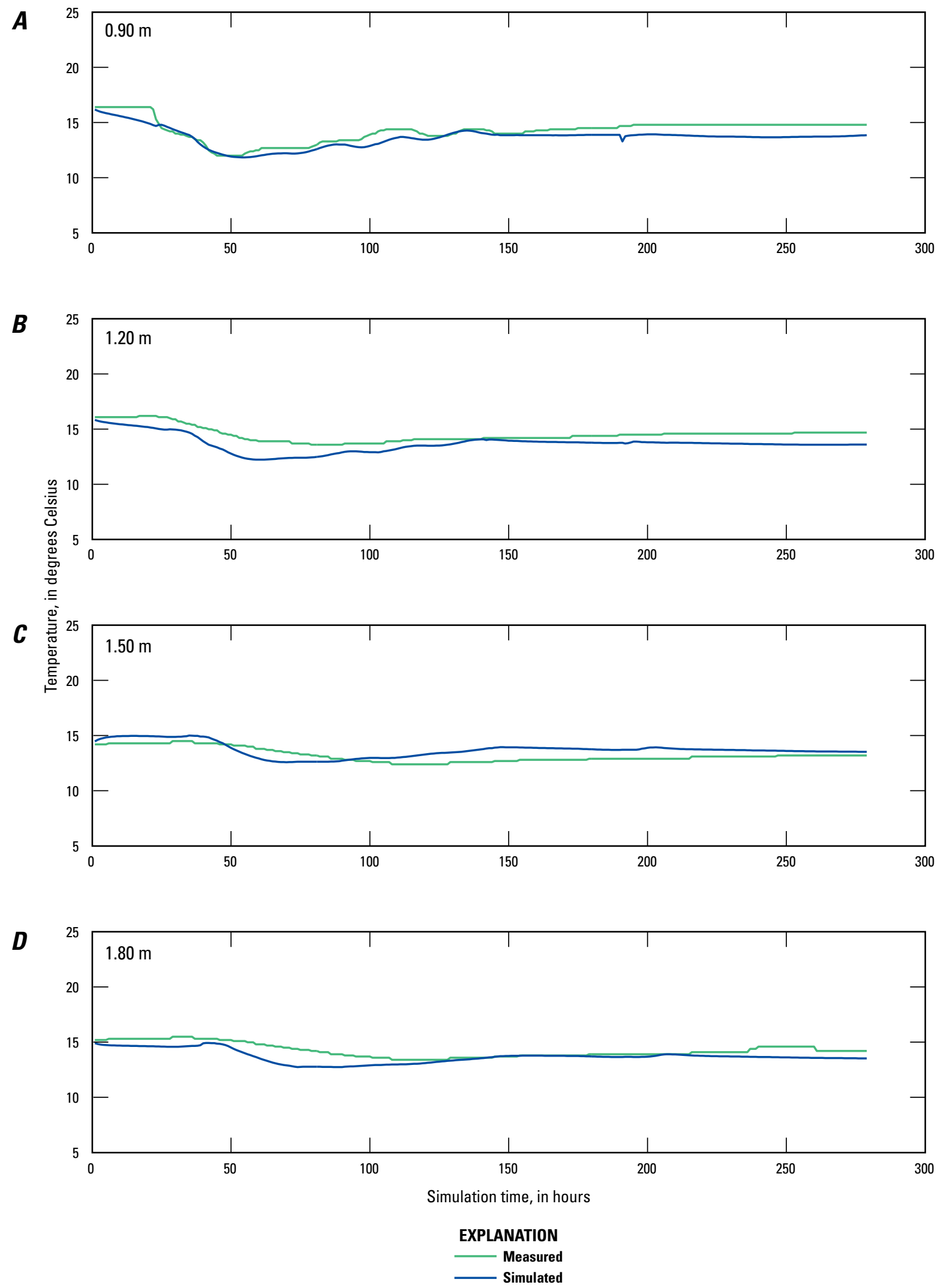

Figure 3C-6. Measured and simulated thermographs for canal sediments for Bank Piezometer 2 (BP2) at depths of A, $0.90 \mathrm{~m}, \mathrm{~B}, 1.20 \mathrm{~m}$, $\mathrm{C}, 1.50 \mathrm{~m}$, and $1.80 \mathrm{~m}$ for the 2013 calibration period. 

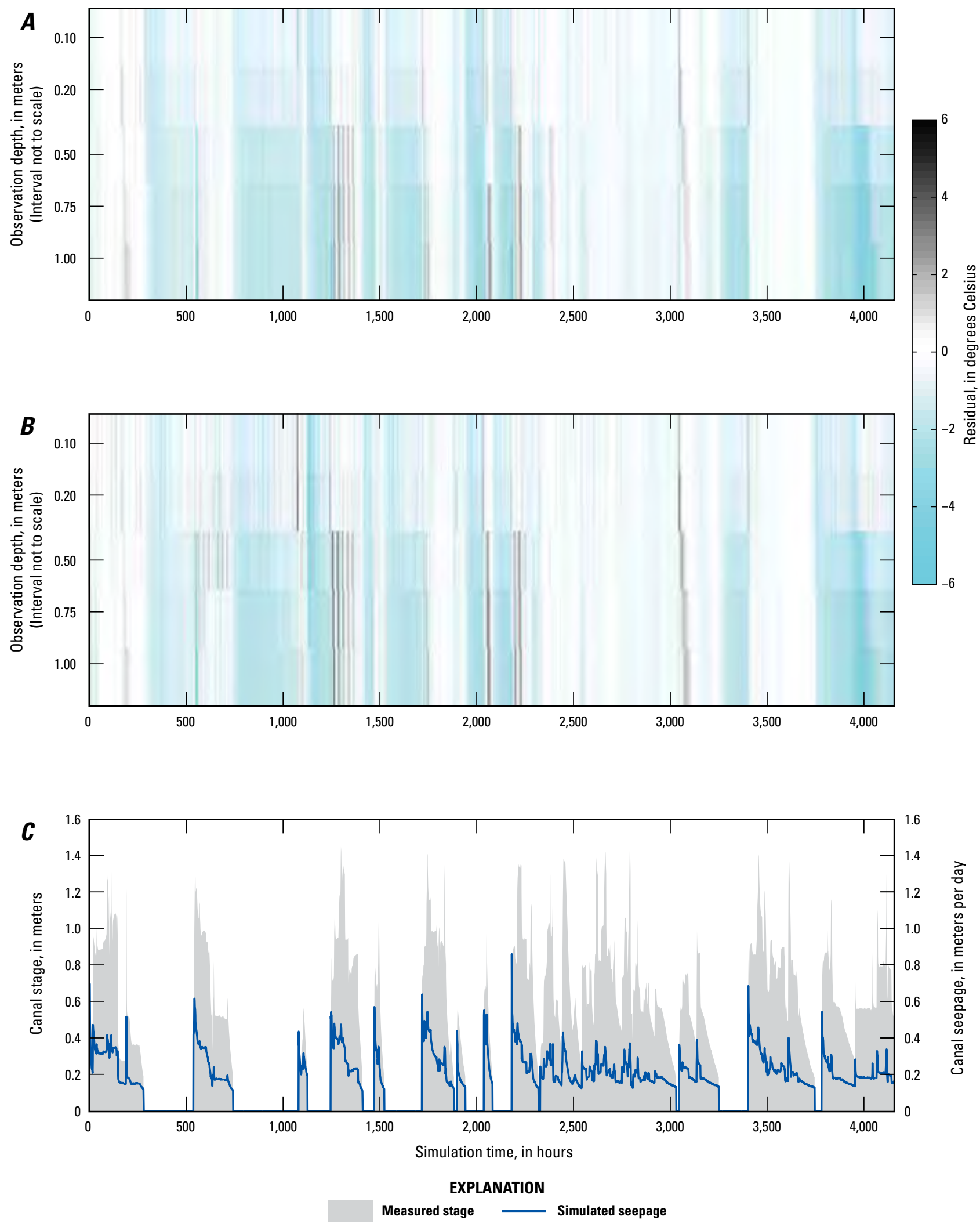

Figure 3C-7. Temperature residual for each depth below the canal at location A, TAA4 and B, TAA5, and C, measured stage and simulated seepage for the 2013 prediction period. 


\section{Appendix 4}

Appendix 4. Textural classification of soil cores collected from selected irrigation canals in the Walker River Basin, Nevada.

[Abbreviation: no., number; cm, centimeters; \%, percent; CL, clay loam; SC, sandy clay; SCL, sandy clay loam; SL, sandy loam; SyC, silty clay; SyCL, silty clay loam]

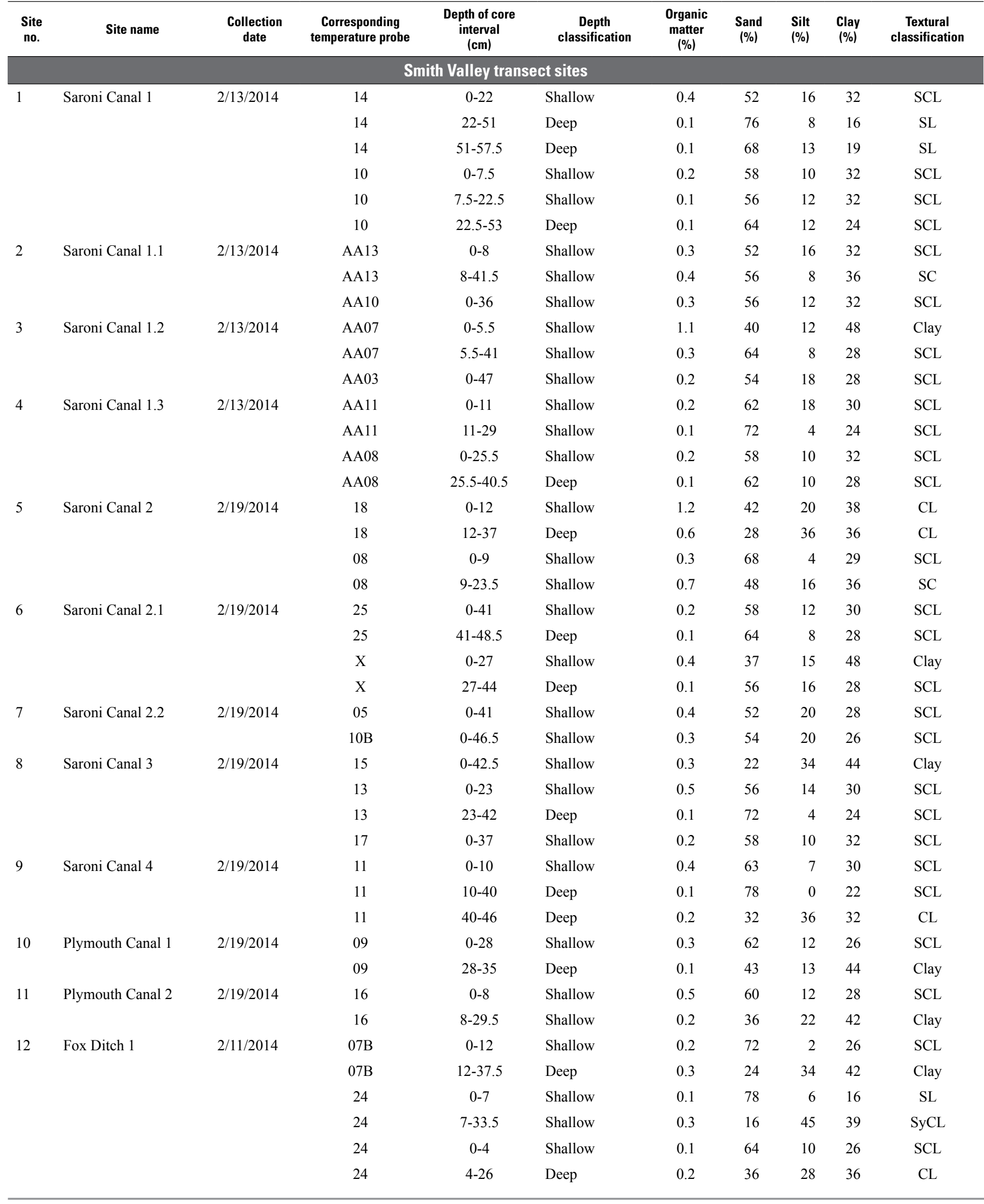


Appendix 4. Textural classification of soil cores collected from selected irrigation canals in the Walker River Basin, Nevada.-Continued [Abbreviation: no., number; cm, centimeters; \%, percent; CL, clay loam; SC, sandy clay; SCL, sandy clay loam; SL, sandy loam; SyC, silty clay; SyCL, silty clay loam]

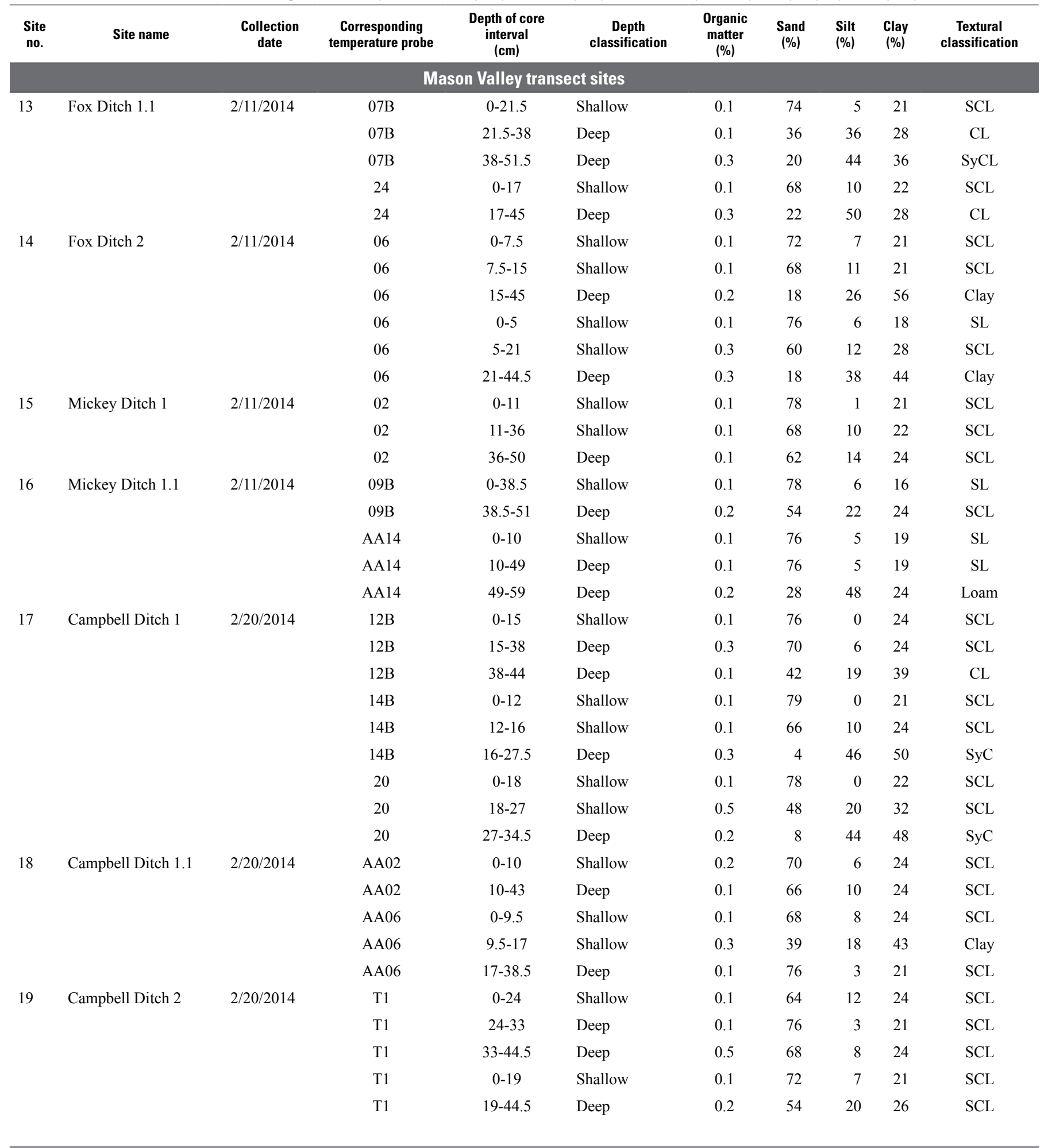


Appendix 4. Textural classification of soil cores collected from selected irrigation canals in the Walker River Basin, Nevada.-Continued [Abbreviation: no., number; cm, centimeters; \%, percent; CL, clay loam; SC, sandy clay; SCL, sandy clay loam; SL, sandy loam; SyC, silty clay; SyCL, silty clay loam]

\begin{tabular}{|c|c|c|c|c|c|c|c|c|c|c|}
\hline $\begin{array}{l}\text { Site } \\
\text { no. }\end{array}$ & Site name & $\begin{array}{l}\text { Collection } \\
\text { date }\end{array}$ & $\begin{array}{l}\text { Corresponding } \\
\text { temperature probe }\end{array}$ & $\begin{array}{l}\text { Depth of core } \\
\text { interval } \\
\text { (cm) }\end{array}$ & $\begin{array}{c}\text { Depth } \\
\text { classification }\end{array}$ & $\begin{array}{c}\text { Organic } \\
\text { matter } \\
(\%)\end{array}$ & $\begin{array}{c}\text { Sand } \\
(\%)\end{array}$ & $\begin{array}{l}\text { Silt } \\
(\%)\end{array}$ & $\begin{array}{l}\text { Clay } \\
(\%)\end{array}$ & $\begin{array}{c}\text { Textural } \\
\text { classification }\end{array}$ \\
\hline \multicolumn{11}{|c|}{ Walker Lake Valley transect sites } \\
\hline \multirow{2}{*}{20} & & & AA12 & $0-27.5$ & Shallow & 0.7 & 52 & 16 & 32 & SCL \\
\hline & & & AA12 & $0-17$ & Shallow & 0.5 & 64 & 8 & 28 & SCL \\
\hline \multirow[t]{4}{*}{21} & Schurz 2 Lateral 1A & $2 / 7 / 2014$ & AA01 & $0-17$ & Shallow & 0.3 & 44 & 18 & 38 & CL \\
\hline & & & AA01 & $17-33.5$ & Deep & 0.1 & 50 & 20 & 30 & SCL \\
\hline & & & AA01 & $0-26$ & Shallow & 0.2 & 52 & 20 & 28 & SCL \\
\hline & & & AA01 & $0-19.5$ & Shallow & 1.0 & 44 & 14 & 42 & Clay \\
\hline \multirow[t]{5}{*}{23} & Schurz 4 Canal 2 & $2 / 7 / 2014$ & AA05 & $0-36.5$ & Shallow & 2.2 & 28 & 28 & 44 & Clay \\
\hline & & & AA05 & $36.5-45.5$ & Deep & 0.1 & 72 & 7 & 21 & SCL \\
\hline & & & AA05 & $45.5-53$ & Deep & 0.1 & 66 & 10 & 24 & SCL \\
\hline & & & AA04 & $0-34$ & Shallow & 0.6 & 32 & 20 & 48 & Clay \\
\hline & & & AA04 & $34-48$ & Deep & 0.1 & 74 & 5 & 21 & SCL \\
\hline
\end{tabular}




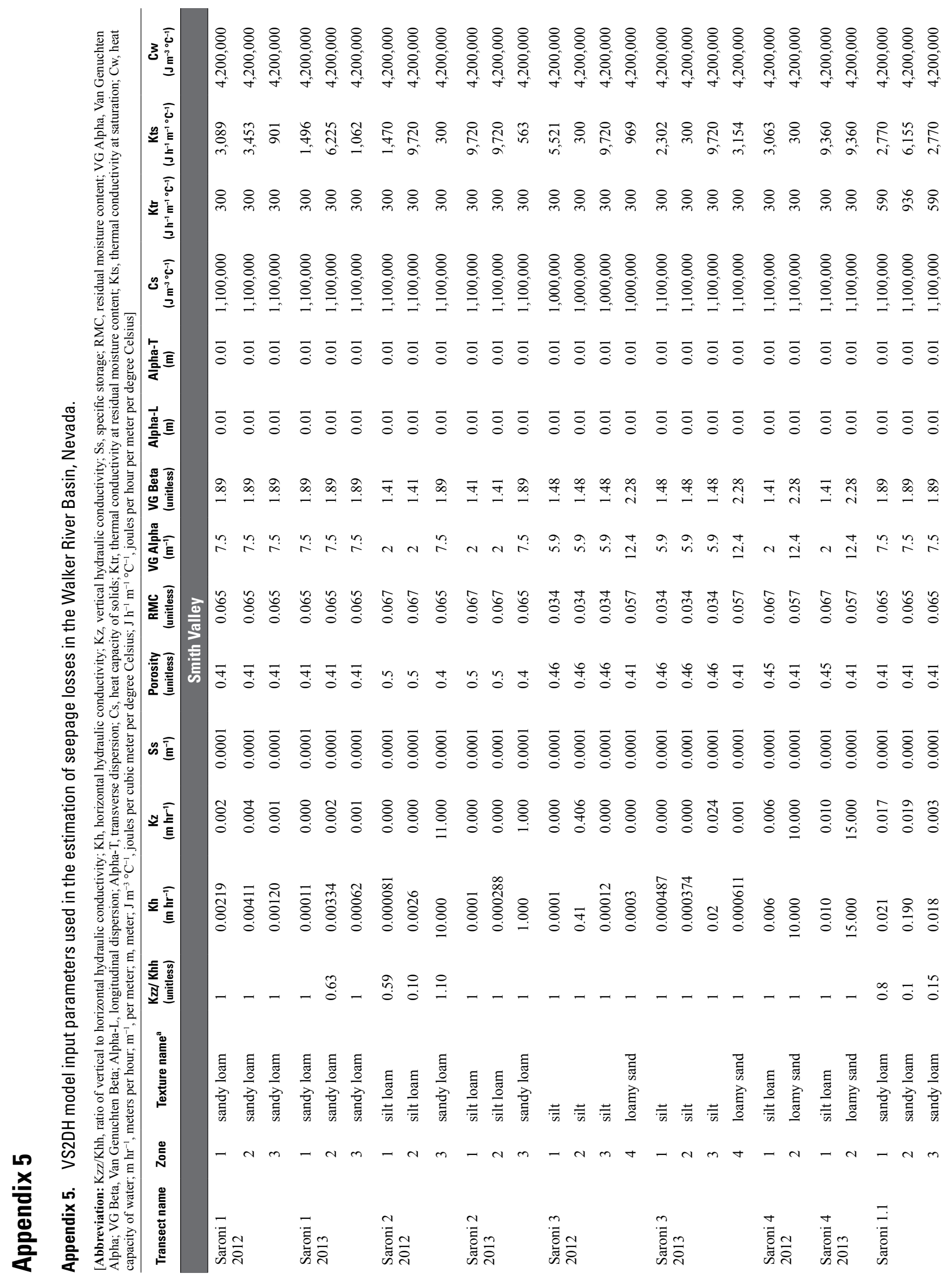




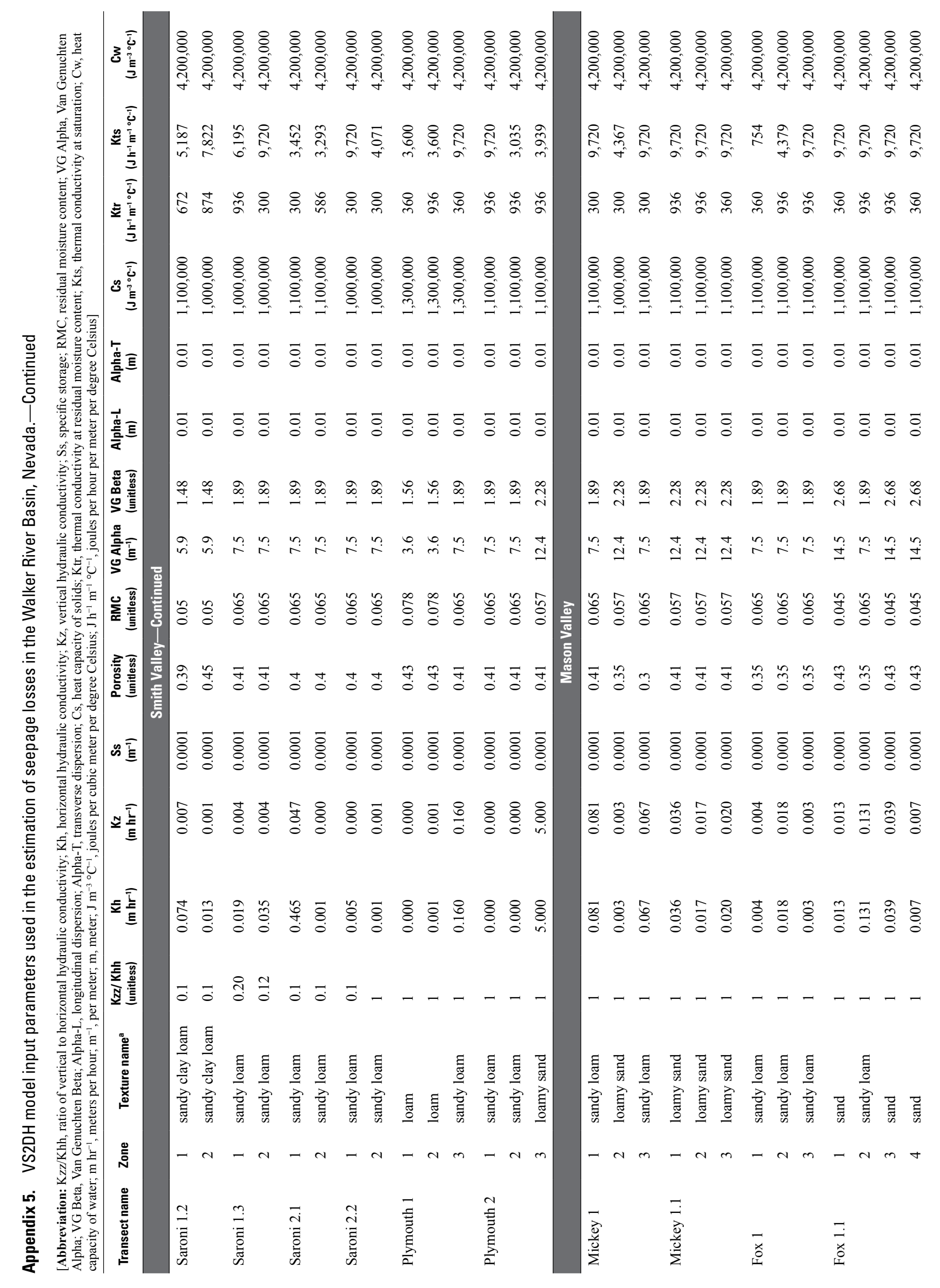




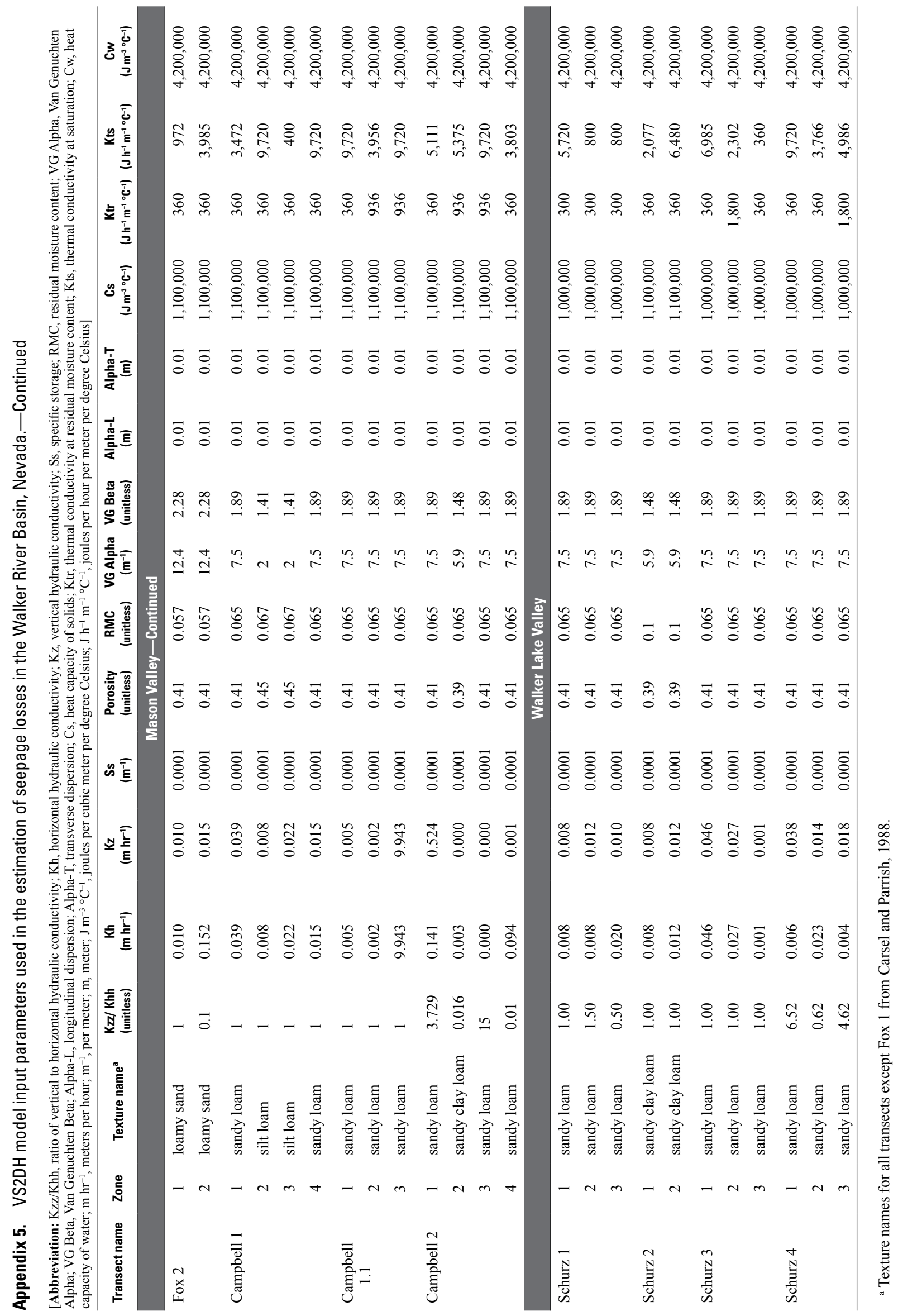




\section{Appendix 6}

Table 6 is distributed as part of this report in Microsoft ${ }^{\circledR}$ Excel 2010 format and is available for download at $h t t p: / / d x$. doi. org/10.3133/sir20165133. 
For additional information, contact:

Director, Nevada Water Science Center U.S. Geological Survey

2730 N. Deer Run Rd.

Carson City, NV 89701

http://nevada.usgs.gov/ 
